\title{
Boildown Study on Supernatant Liquid Retrieved from AW-106 in December 2012
}

\section{J. S. Page}

Washington River Protection Solutions LLC

Date Published

May 2013

\section{washington river} protectionsolutions

Prepared for the U.S. Department of Energy Office of River Protection

Contract No. DE-AC27-08RV14800 


\section{LEGAL DISCLAIMER}

This report was prepared as an account of work sponsored by an agency of the United States Government. Neither the United States Government nor any agency thereof, nor any of their employees, makes any warranty, express or implied, or assumes any legal liability or responsibility for the accuracy, completeness, or any third party's use or the results of such use of any information, apparatus, product, or process disclosed, or represents that its use would not infringe privately owned rights. Reference herein to any specific commercial product, process, or service by trade name, trademark, manufacturer, or otherwise, does not necessarily constitute or imply its endorsement, recommendation, or favoring by the United States Government or any agency thereof or its contractors or subcontractors. The views and opinions of authors expressed herein do not necessarily state or reflect those of the United States Government or any agency thereof.

This report has been reproduced from the best available copy.

Printed in the United States of America 


\section{EXECUTIVE SUMMARY}

This document reports the results of a boildown study using a composite created from supernatant liquid grab samples retrieved from tank 241-AW-106 in December of 2012. The composite was made using predetermined volumes of the grab samples which accounted for layering of the supernatant liquid in the tank. The finished composite was a clear, yellow liquid containing no visible solids at hot cell ambient temperatures $\left(24-27^{\circ} \mathrm{C}\right)$. The density of the test composite was measured in the hot cell immediately before the boildown study and was $1.266 \mathrm{~g} / \mathrm{mL}$ at $27.1^{\circ} \mathrm{C}$.

The boiling temperature of the composite was measured at three different pressures $(40,60$, and 80 Torr) throughout the volume reduction, and the results show steadily increasing boiling temperatures with increasing volume reduction and no significant discontinuities. Moderate foaming was observed at the onset of the boildown. The foaming disappeared during the first reduction step, and minimal foaming was observed throughout the rest of the study.

The bulk densities at $18.0{ }^{\circ} \mathrm{C}\left(\mathrm{D}_{\mathrm{Bulk}}{ }^{1{ }^{\circ} \mathrm{C}}\right)$ and quantities of settled and centrifuged solids were measured on samples of the boildown concentrates. Estimated values of the bulk densities at the 60 -Torr boiling temperatures $\left(\mathrm{D}_{\text {Bulk }}{ }^{60}\right.$ Torr $)$ were also calculated. The densities and solids content of concentrates at four levels of percent waste volume reduction (\%VWR) were:

\begin{tabular}{|l|c|c|c|c|}
\hline$\% W V R$ & 34.7 & 39.3 & 44.1 & 48.7 \\
\hline $\mathrm{D}_{\text {Bulk }}{ }^{1{ }^{\circ} \mathrm{C}}$ (measured) & 1.400 & 1.424 & 1.457 & 1.495 \\
\hline $\mathrm{D}_{\text {Bulk }}{ }^{60 \text { Torr }}$ (estimated) & 1.378 & 1.401 & 1.436 & 1.474 \\
\hline Vol\% Settled Solids $\left(18^{\circ} \mathrm{C}\right)$ & 0.0 & 2.2 & 51.3 & 47.8 \\
\hline Vol\% Centrifuged Solids $\left(18^{\circ} \mathrm{C}\right)$ & 1.5 & 3.2 & 25.3 & 31.5 \\
\hline
\end{tabular}

Solids were first observed at boildown temperatures when the \%VWR reached $39.3 \%$. The quantity of solids in the composite quickly increased after this initial formation; the amount of centrifuged solids increased by $22 \%$ as the $\%$ WVR increased from 39.3 to $44.1 \%$. A small amount of solids did appear in the samples collected prior to the initial formation during the boildown. These solids precipitated while they sat at hot cell ambient temperature and in the $18.0^{\circ} \mathrm{C}$ water bath.

Analysis of boildown test samples indicated that natrophosphate $\left(\mathrm{Na}_{7} \mathrm{~F}\left(\mathrm{PO}_{4}\right)_{2} \cdot 19 \mathrm{H}_{2} \mathrm{O}\right)$ and kogarkoite $\left(\mathrm{Na}_{3} \mathrm{FSO}_{4}\right)$ accounted for a majority of the initial solids ( $80 \%$ of the dissolved sulfate and phosphate precipitated from the composite by $44.1 \% \mathrm{WVR})$. The large increase in solids at $44.1 \%$ WVR was dominated by sodium nitrate and sodium carbonate. 


\section{TABLE OF CONTENTS}

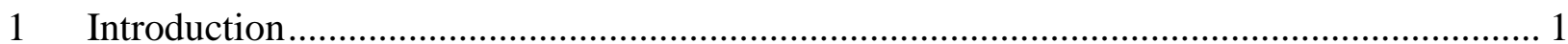

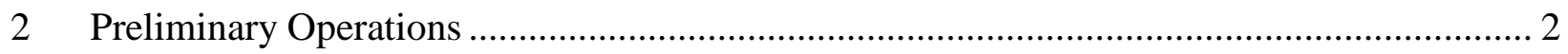

2.1 Preparation of Test Composite ............................................................................... 2

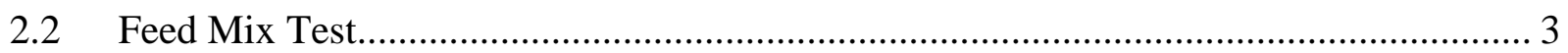

2.3 Boildown Apparatus....................................................................................... 4

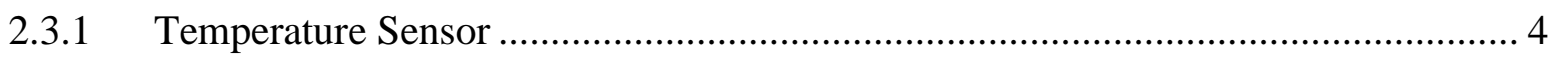

2.4 Pressure Sensor/Controller ............................................................................. 4

2.4.1 Boildown Pot ........................................................................................ 5

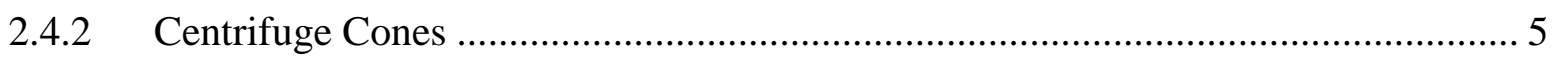

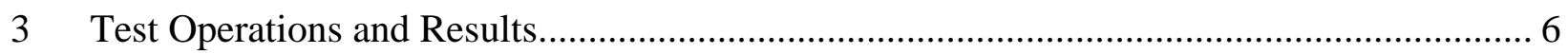

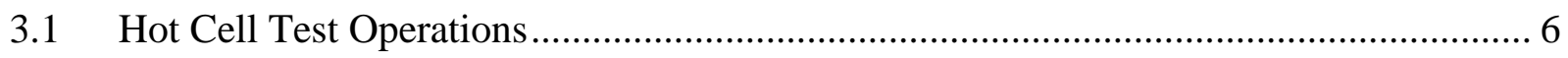

3.1.1 Boildown Progress Parameters ........................................................................ 6

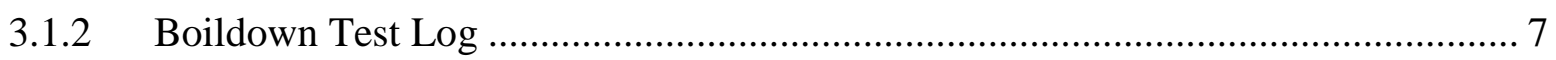

3.2 Hot Cell Sample Processing ................................................................................ 12

3.2.1 Initial Sample Processing ............................................................................. 12

3.2.2 Final Sample Processing ............................................................................. 12

3.2.3 Densities of Boildown Sample Liquids ........................................................... 16

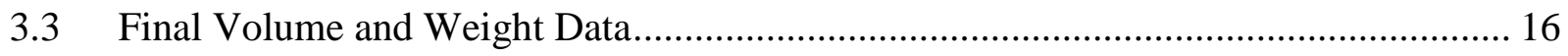

$4 \quad$ Laboratory Analysis of Boildown Samples ............................................................... 19

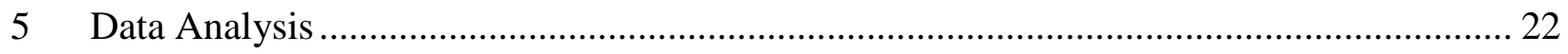

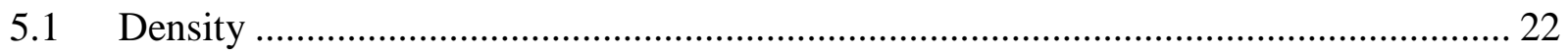

5.1.1 Bulk Density of Tank 241-AW-106 Boildown Samples .................................... 22

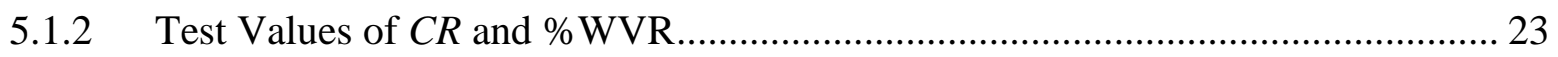

5.1.3 Volumes and Densities at Process Temperatures ............................................ 25

5.2 Boildown Temperature Curves ........................................................................... 27

5.3 Quantity of Solids in Cool Concentrates ................................................................ 29

5.3.1 Boildown Volume Reduction Samples ........................................................... 29

5.3.2 End-point Slurry Dilution Samples.................................................................. 32

5.3.3 Calculated Weights of Solids in Boildown Samples .......................................... 32

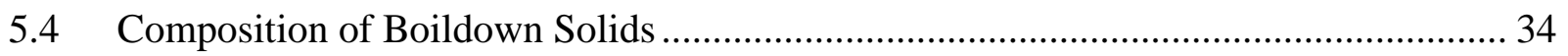

5.4.1 Quantities of Species Remaining in Solution ................................................... 34

5.4.2 Solid Phase Characterization Results............................................................ 45 
5.4.3 Solid Phases Present in Concentrate Solids ......................................................... 47

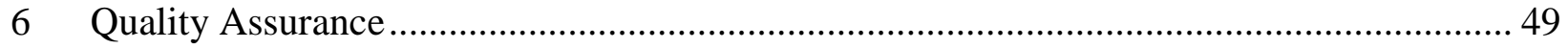

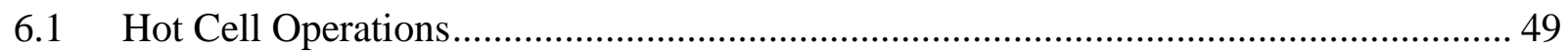

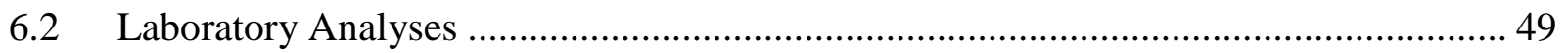

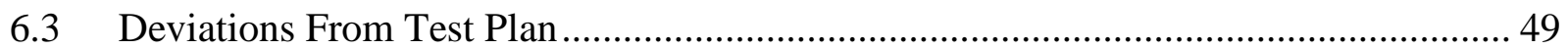

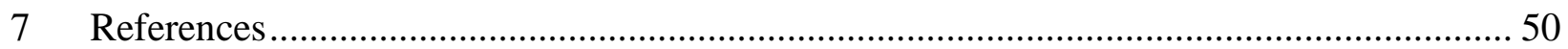

ATTACHMENT A - Volume Calibration of Centrifuge Cones............................................... A-i

ATTACHMENT B - Boildown Hot Cell Data Logs .......................................................... B-i

ATTACHMENT C - Photographs of Boildown Samples.................................................. C-i

ATTACHMENT D - Laboratory Analysis Results................................................................. D-i

ATTACHMENT E - Solid Phase Characterization of Boildown Solids .......................................E-i 
LAB-RPT-13-00003 R0

\section{List of Figures}

Figure 2-1. Feed Mix Testing of Tank 241-AW-106 and Tank 241-AP-107 Supernatant

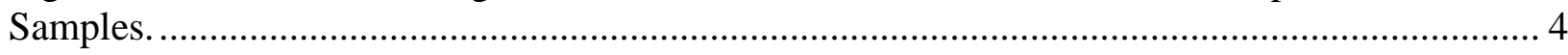

Figure 3-1. Tank 241-AW-106 Composite during the Early Stages of the Volume Reduction.... 8

Figure 3-2. Tank 241-AW-106 Composite during Mid Stages of the Volume Reduction........... 9

Figure 3-3. Tank 241-AW-106 Composite During the End Stages of the Volume Reduction. .. 10

Figure 3-4. Tank 241-AW-106 Composite during the Volume Dilution. ................................ 11

Figure 3-5. Density of Sample Liquids versus Tank 241-AW-106 Boildown Progress. ........... 18

Figure 5-1. Comparison of Model and Measured Bulk Densities. ......................................... 23

Figure 5-2. Bulk Densities at $18{ }^{\circ} \mathrm{C}$ versus Concentration Ratio........................................... 25

Figure 5-3. Bulk Densities at Process Temperatures versus $\% \mathrm{WVR}^{18{ }^{\circ} \mathrm{C}}$............................... 27

Figure 5-4. Boiling Temperature versus Boildown Progress................................................ 28

Figure 5-5. Quantity of Solids in Cooled Concentrates..................................................... 30

Figure 5-6. Quantities of New Solids in Concentrates. ......................................................... 31

Figure 5-7. Quantity of Solids in Dilution Samples at $18{ }^{\circ} \mathrm{C}$................................................ 32

Figure 5-8. Calculated and Measured Weights of Solids in Concentrates. .............................. 34

Figure 5-9. Weights of Species Remaining in Solution at $18{ }^{\circ} \mathrm{C}$. (8 sheets) ........................... 36

Figure 5-10. Estimated Weights of Species in $18{ }^{\circ} \mathrm{C}$ Solids. ............................................... 44

Figure 5-11. Estimated Vol\% of Solid Phases in Concentrate Solids. ...................................... 48

\section{List of Tables}

Table 2-1. Preparation of Tank 241-AW-106 Composite for Boildown Study.......................... 2

Table 2-2. Density of Tank 241-AW-106 Composite Measured in Hot Cell.............................. 3

Table 3-1. Appearance of Settled Solids in Boildown Samples. ........................................... 13

Table 3-2. Identification of Tank 241-AW-106 Boildown Samples. ....................................... 15

Table 3-3. Gravimetric and Volumetric Data for Tank 241-AW-106 Boildown Samples.......... 17

Table 4-1. Results of Analyses of Tank 241-AW-106 Boildown Sample Liquids. ................... 20

Table 5-1. Calculation of Test Values of $C R$ and \%WVR. .................................................. 24

Table 5-2. Adjusted Sample Volumes and Densities at Process Temperatures. ....................... 26

Table 5-3. Estimated Dry Weights of Solids in Concentrates at $18{ }^{\circ} \mathrm{C}$.................................. 33

Table 5-4. Solid Phases Identified in C-Slds Samples.......................................................... 46 


\section{LIST OF TERMS}

\section{Abbreviations and Acronyms}

ATL

AP-107

AW-106

C-Liq

C-Sld(s)

ChgBal

CON-\#

$\mathrm{CP}$

$C R$

$C R^{\circ} \mathrm{C}$

$C R_{\text {Model }}{ }^{\circ} \mathrm{C}$

$C R_{\text {Step }}$

$\mathrm{D}$

$\mathrm{D}_{\text {Bulk }}$

$\mathrm{D}_{\text {Bulk }}{ }^{\circ} \mathrm{C}$

$D_{\text {Bulk }} 60$ Torr

$\mathrm{D}_{\text {Liq }}{ }^{\circ} \mathrm{C}$

$\mathrm{D}_{\text {Model }}{ }^{\circ} \mathrm{C}$

DIL-\#

IC

ICP-AES

Liq

MDL

MDW

NIST

OmniLIMS

$\%$-Rec

$\% \mathrm{WVR}$

$\% \mathrm{WVR}{ }^{\circ} \mathrm{C}$

$\% \mathrm{WVR}_{\text {Model }}{ }^{\circ} \mathrm{C}$

POC

$\mathrm{P}_{\text {Read }}$

$\mathrm{P}_{\text {Corrected }}$

$\mathrm{P} / \mathrm{T}$

PLM

RPD

RTD

SEI
Advanced Technologies and Laboratories International, Inc.

tank 241-AP-107

tank 241-AW-106

centrifuged liquid

centrifuged solid(s)

charge balance ratio

step or sample number in boildown volume reduction

initial test composite

cumulative concentration ratio

cumulative concentration ratio at indicated temperature

cumulative concentration ratio at indicated temperature calculated using additive volumes model

concentration ratio for a discrete step in a boildown test sequence

density

bulk density (i.e. total density of a sample containing liquid and solids)

bulk density at indicated temperature

estimated bulk density at boiling temperature at 60 Torr

liquid density at indicated temperature

density at indicated temperature calculated using additive volumes model

step or sample number in dilution of end-point slurry

ion chromatography

inductively coupled plasma-atomic emission spectrometry

liquid(s)

minimum detection limit

minimum detectable weight

National Institute of Standards and Technology

222-S Laboratory Information Management System

percent recovery

percent waste volume reduction

percent waste volume reduction at indicated temperature

percent waste volume reduction at indicated temperature calculated using additive volumes model

point of contact

pressure as read from transducer display

corrected system pressure

combination measurement of boiling temperature at specified pressure

polarized light microscopy

relative percent difference

resistance temperature detector

secondary electron image 
SEM/EDX

Slds

S-Sld(s)

SPC

$\mathrm{T}$

$\mathrm{T}_{\text {Read }}$

$\mathrm{T}_{\text {Corrected }}$

TIC

TOC

$\triangle \mathrm{TOC}$

Total C

TSAP

Vol

Vol $_{\text {Read }}$

Vol ${ }_{\text {Corrected }}$

vol\%

$f_{\text {Liq }}$

$f_{\text {SIds }}$

$\mathrm{Wt}$

wt $\%$

XRD

\section{Units}

${ }^{\circ} \mathrm{C}$

$\mathrm{cm}$

$g$

$\mathrm{g}$

$\mathrm{g} / \mathrm{L}$

$\mathrm{g} / \mathrm{mL}$

$\mathrm{kV}$

$\operatorname{hr}(\mathrm{s})$

$\mathrm{L}$

$\mu \mathrm{m}$

$\mu \mathrm{g} / \mathrm{mL}$

$\mathrm{mL}$

$(\Delta \mathrm{mL} / \mathrm{mL}) / \Delta^{\circ} \mathrm{C}$

$\mathrm{mm}$

Torr scanning electron microscopy with energy dispersive X-ray spectroscopy solids

settled solid(s)

solid phase characterization

temperature

temperature as read from thermocouple display

corrected system temperature

total inorganic carbon

total organic carbon

reported TOC minus the sum of the carbon from reported concentrations of organic acid anions

total carbon

Tank Sampling Analysis Plan

volume

volume read from centrifuge cone volume scale

corrected volume of sample in centrifuge cone

percent by volume

volume fraction of liquid in a sample

volume fraction of solids in a sample

weight

percent by weight

[powder] X-ray diffraction (or diffractometry) degree(s) Celsius

centimeter(s)

acceleration due to gravity (used to define relative centrifugal force)

grams

grams per liter

grams per milliliter

kilovolts

hour(s)

liter(s)

micrometer

micrograms per milliliter

milliliter

change in milliliters per milliliter per change in degree Celsius (units of thermal expansion coefficient)

millimeter

unit of pressure equivalent to $1 \mathrm{~mm} \mathrm{Hg}$ 


\section{INTRODUCTION}

A boildown study was conducted at the 222-S Laboratory on supernatant liquid retrieved from tank 241-AW-106 (AW-106) in December of 2012. This study characterized the behavior of a composite, created from multiple grab samples of the supernatant liquid, during volume reduction at the reduced pressures of 40,60, and 80 Torr $(\mathrm{mm} \mathrm{Hg})$ as requested in the tank sampling and analysis plan (TSAP; RPP-PLAN-53006, Tank 241-AW-106 Grab Sampling and Analysis Plan in Support of Evaporator Campaign for Fiscal Year 2013) to support operations at the 242-A Evaporator. The boildown study was performed in hot cells 11A-5 and 11A-6 at the 222-S Laboratory in accordance with the customer-approved test plan (LAB-PLN-13-00001, Test Plan for Boildown Study on Supernate Retrieved from 241-AW-106 in December 2012). The operation of the boildown apparatus in hot cell 11A-6 was done in accordance with the Laboratory Technology Procedure ATS-LT-519-183, "222-S Laboratory Determination of Properties of Radiological Solutions as a Function of Volume Reduction at Reduced Pressure."

The boildown study was designed (1) to determine the relationship between solids formation and percent waste volume reduction (\%WVR), (2) to determine the relationship between concentrate density and \%WVR, (3) to determine the type and quantity of solids that may form in the AW-106 concentrates after cooling in the storage tanks at ambient temperatures, and (4) to define the relationship between boiling temperature and concentration of the composite sample. To obtain this information, the boildown study progressed through four stages:

Composite preparation

Boildown concentration

End-point slurry dilution

Sample processing
A composite of the AW-106 liquid waste was prepared from grab samples in proportion to the tank layering of the supernatant liquid.

Volume reduction of the AW-106 composite was performed at reduced pressures. Samples of the composite were withdrawn at sampling points defined by calculated, target densities of the concentrate.

The end-point slurry from the concentration sequence was diluted, in increments, reconstituting the composite to the early stages of the volume reduction.

Samples collected during the concentration and dilution sequences were processed and physicochemical analyses conducted. 


\section{PRELIMINARY OPERATIONS}

\subsection{PREPARATION OF TEST COMPOSITE}

A composite of the AW-106 supernatant liquid grab samples was prepared volumetrically on February 11, 2013, as specified in the test plan and detailed in Table 2-1. Density values were reported for each grab sample by the 222-S Laboratory (RPP-RPT-54430, Final Report for Tank 241-AW-106 Grab Samples in Support of Evaporator Campaign for Fiscal Year 2013) and show the layering of the supernatant liquid in the tank. A small scattering of fine particulate on the bottom of the amber glass jar was observed in grab samples 6AW-12-03A, -04, and -04A. After consultation with the evaporator point of contact (POC), the particles were left in the jars and allowed to transfer into the composite. After composite creation, no appreciable solids were observed in the composite; the particulate either did not transfer or it dissolved in the solution. The final composite was a clear, yellow liquid containing no visible solids.

Table 2-1. Preparation of Tank 241-AW-106 Composite for Boildown Study.

\begin{tabular}{|c|c|c|c|c|c|c|}
\hline \multicolumn{2}{|c|}{ Sample Number } & \multirow[b]{2}{*}{ Location } & \multirow[b]{2}{*}{ Density } & \multicolumn{3}{|c|}{ Added to Composite } \\
\hline Grab Sample & OmniLIMS $^{\text {a }}$ & & & g & $\mathbf{m L}$ & Vol\% \\
\hline $6 \mathrm{AW}-12-01$ & $\mathrm{~S} 12 \mathrm{~T} 022783$ & Surface & - & - & - & - \\
\hline $6 \mathrm{AW}-12-02$ & $\mathrm{~S} 12 \mathrm{~T} 022785$ & \multirow{3}{*}{$\begin{array}{l}\approx 1 / 6 \text { of distance } \\
\text { surface to solids }\end{array}$} & \multirow{2}{*}{1.242} & 148.99 & 122.0 & \multirow{3}{*}{41.0} \\
\hline $6 \mathrm{AW}-12-02 \mathrm{~A}$ & S12T022787 & & & 126.05 & 103.5 & \\
\hline 6AW-12-02DUP & $\mathrm{S} 12 \mathrm{~T} 022797$ & & 1.237 & - & - & \\
\hline $6 \mathrm{AW}-12-03$ & $\mathrm{~S} 12 \mathrm{~T} 022803$ & \multirow{2}{*}{$\begin{array}{l}\approx 1 / 2 \text { of distance } \\
\text { surface to solids }\end{array}$} & \multirow{2}{*}{1.244} & 193.61 & 158.5 & \multirow{2}{*}{41.0} \\
\hline $6 \mathrm{AW}-12-03 \mathrm{~A}$ & S12T022805 & & & 81.92 & 67.0 & \\
\hline $6 \mathrm{AW}-12-04$ & $\mathrm{~S} 12 \mathrm{~T} 022815$ & \multirow{2}{*}{$\begin{array}{l}\approx 5 / 6 \text { of distance } \\
\text { surface to solids }\end{array}$} & \multirow{2}{*}{1.400} & 35.25 & 27.0 & \multirow{2}{*}{18.0} \\
\hline $6 \mathrm{AW}-12-04 \mathrm{~A}$ & $\mathrm{~S} 12 \mathrm{~T} 022817$ & & & 97.98 & 72.0 & \\
\hline Composite & S13T001219 & - & & 683.80 & 550.0 & 100.0 \\
\hline
\end{tabular}

${ }^{a}$ 222-S Laboratory Information Management System.

The density of the composite was measured in the 11A-6 hot cell as it was transferred to the glass pot in the boildown apparatus. The density measurement data is presented in Table 2-2. Three Class A, 100-mL volumetric flasks were filled with the composite liquid and weighed. The temperature of the composite liquid was $27.1{ }^{\circ} \mathrm{C}$. The average density of the AW-106 composite was $1.266 \pm 0.001 \mathrm{~g} / \mathrm{mL}$. 
LAB-RPT-13-00003 R0

Table 2-2. Density of Tank 241-AW-106 Composite Measured in Hot Cell.

\begin{tabular}{|c|c|c|c|}
\hline & Flask A & Flask B & Flask C \\
\hline \multicolumn{4}{|c|}{ Reagent $\mathrm{H}_{2} \mathrm{O}$ (not deaerated) } \\
\hline Nominal flask volume (mL) & \multicolumn{3}{|c|}{$100 \pm 0.08$} \\
\hline Wt reagent $\mathrm{H}_{2} \mathrm{O}$ to fill flask $(\mathrm{g})$ & 99.528 & 99.593 & 99.554 \\
\hline Temperature of $\mathrm{H}_{2} \mathrm{O}\left({ }^{\circ} \mathrm{C}\right)$ & \multicolumn{3}{|c|}{24.0} \\
\hline Reference $\mathrm{H}_{2} \mathrm{O}$ density $(\mathrm{g} / \mathrm{mL})$ & \multicolumn{3}{|c|}{0.997296} \\
\hline Calculated $\mathrm{H}_{2} \mathrm{O}$ density $(\mathrm{g} / \mathrm{mL})$ & .995 & .996 & .996 \\
\hline \multicolumn{4}{|c|}{ AW-106 Composite } \\
\hline Wt composite to fill flask (g) & 126.497 & 126.741 & 126.536 \\
\hline Calculated composite density (g/mL) & 1.265 & 1.267 & 1.265 \\
\hline Temperature of composite $\left({ }^{\circ} \mathrm{C}\right)$ & \multicolumn{3}{|c|}{27.1} \\
\hline Average composite density $(\mathrm{g} / \mathrm{mL})$ & \multicolumn{3}{|c|}{$1.266 \pm 0.001 \mathrm{~g} / \mathrm{mL}$} \\
\hline Density reported by $222-\mathrm{S}(\mathrm{g} / \mathrm{mL})^{\mathrm{a}}$ & \multicolumn{3}{|c|}{1.250} \\
\hline
\end{tabular}

On February 12, 2013, approximately $13 \mathrm{~mL}$ of the composite (Sample CP) was transferred to a $15-\mathrm{mL}$ centrifuge cone. To ensure that enough sample was available for chemical analysis of the composite, an additional $17 \mathrm{~mL}$ of the composite was placed in a glass vial and assigned sample number S13T001220. The cone was suspended in a water bath maintained at $18.0{ }^{\circ} \mathrm{C}$ for 5 days. No physical changes (specifically, no solids formation) were observed. The liquid in the cone was then transferred to a second sample vial and assigned sample number S13T001221.

\subsection{FEED MIX TEST}

On February 13, 2013, equal portions of the AW-106 composite and an archived grab sample from tank 241-AP-107 (AP-107) were combined. Consecutive boildowns were scheduled to be run on feeds from AP-107 and AW-106, and the feed mix test was requested to observe any physical changes, e.g., solids formation, gas generation, color change, temperature change, and clarity upon mixing. Approximately $20 \mathrm{~mL}$ of the AW-106 composite was placed in a glass vial, and $\sim 20 \mathrm{~mL}$ of the AP-107 grab sample, 7AP-10-02A, was placed in a 50-mL centrifuged cone, Figure 2-1A. Both samples were clear and yellow with no visible solids, and the temperatures were $24.0{ }^{\circ} \mathrm{C}$ for the AW-106 sample and $24.2{ }^{\circ} \mathrm{C}$ for the AP-107 sample.

The AW-106 sample was then combined with the AP-107 sample in the centrifuge cone and gently swirled. There were no signs of gas evolution or solid formation, and the liquid remained clear, Figure 2-1B. The temperature of the solution was $24.1{ }^{\circ} \mathrm{C}$ indicating no exothermic or endothermic reactions occurred. After 6 days of periodic observations in the hot cell, there were no changes to the solution; it remained clear with no visible solids, Figure 2-1C. 
Figure 2-1. Feed Mix Testing of Tank 241-AW-106 and Tank 241-AP-107 Supernatant

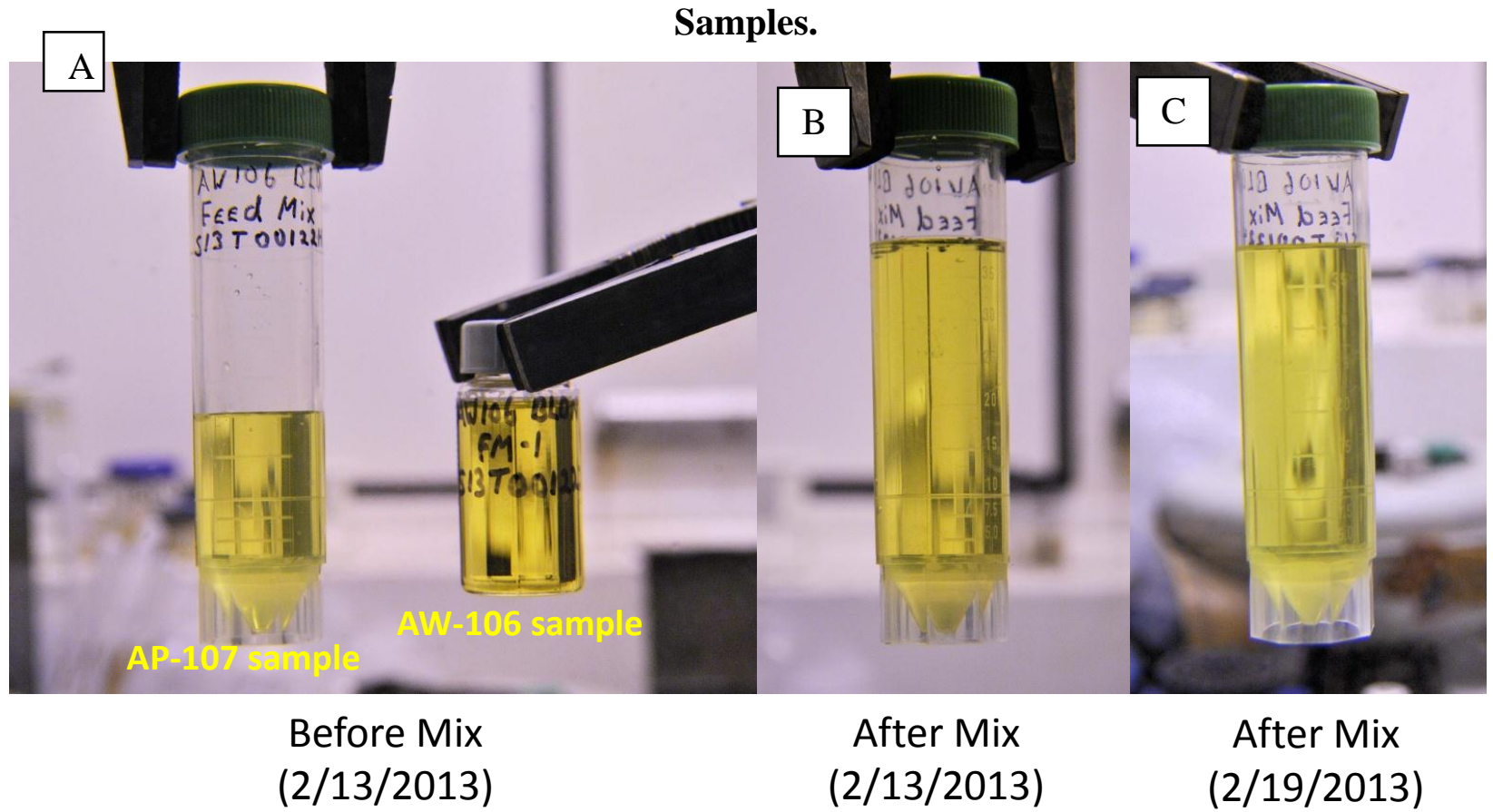

\subsection{BOILDOWN APPARATUS}

\subsubsection{Temperature Sensor}

A K-type thermocouple was used to measure the temperature of the composite in the boildown apparatus. The thermocouple signal was converted to a temperature readout $\left(\mathrm{T}_{\text {Read }}\right)$ using a Fisher ${ }^{1}$ Model M107568 thermocouple reader. The $\mathrm{T}_{\text {Read }}$ values were changed to corrected temperatures $\left(\mathrm{T}_{\text {Corrected }}\right)$ using a calibration equation comparing the $\mathrm{T}_{\text {Read }}$ with 'true' temperatures measured with a National Institute of Standards and Technology (NIST) certified, platinum RTD digital thermometer (Ebro $\AA^{2}$ Electronic, Model TFX410-1/TPX100, Serial Number 15100653/15073983). Comparative temperature readings were made as initially cold reagent water in the boildown pot was slowly heated to boiling and then allowed to cool while being stirred gently. The resulting temperature calibration equation was:

$$
\mathrm{T}_{\text {Corrected }}{ }^{\circ} \mathrm{C}=\left(2.81 \times 10^{-6}\right)\left(\mathrm{T}_{\text {Read }}\right)^{3}-\left(7.16 \times 10^{-4}\right)\left(\mathrm{T}_{\text {Read }}\right)^{2}+(1.04)\left(\mathrm{T}_{\text {Read }}\right)+1.20
$$

\subsection{PRESSURE SENSOR/CONTROLLER}

The pressure within the boildown pot was read from a Cole-Parmer ${ }^{\circledR 3}$ Instrument Company, Model 68801-23 pressure reader/controller. A calibration equation was generated to change

\footnotetext{
${ }^{1}$ Thermo Fisher Scientific Inc., Waltham, Massachusetts.

${ }^{2}$ ebro® is a registered trademark of ebro Electronic Gmbh \& Co. KG, Ingolstadt, Fed Rep Germany.

${ }^{3}$ Cole-Parmer ${ }^{\circledR}$ is a registered trademark of Cole-Parmer Instrument Company, Vernon Hills, Illinois.
} 
pressure readings $\left(\mathrm{P}_{\text {Read }}\right)$ from the reader/controller to corrected pressures $\left(\mathrm{P}_{\text {Corrected }}\right)$. Sets of $\mathrm{T}_{\text {Corrected }}$ and $\mathrm{P}_{\text {Read }}$ values were recorded as reagent water was boiled at pressures ranging from 24 to 98 Torr. The $\mathrm{P}_{\text {Read }}$ values were then compared with reference values for the vapor pressure of pure water at $\mathrm{T}_{\text {Corrected }}$. The resulting pressure calibration equation was:

$$
\mathrm{P}_{\text {Corrected }} \text { Torr }=(1.01)\left(\mathrm{P}_{\text {Read }}\right)+3.50
$$

\subsubsection{Boildown Pot}

The glass boildown pot used in this study has a maximum working volume of $500 \mathrm{~mL}$ and a minimum working volume of $\sim 75 \mathrm{~mL}$. The main portion of the pot is a flat-bottomed cylindrical vessel with an inner diameter of $7.9 \mathrm{~cm}$ and a height of $9.5 \mathrm{~cm}$. There are three vertical, fin-like indentations protruding $6 \mathrm{~mm}$ into the interior of the pot which facilitate mixing of the pot contents when stirred by a magnetic stir bar. The upper portion of the pot is tapered (over $2.5 \mathrm{~cm}$ ) to a cylindrical throat with an inner diameter of $5 \mathrm{~cm}$. The top surface of the upper throat contains a groove for the O-ring joint by which the pot is connected to the rest of the boildown apparatus. Heating of the pot contents is accomplished by bringing a laboratory hotplate/magnetic stirrer into contact with the bottom of the pot.

\subsubsection{Centrifuge Cones}

The AW-106 boildown samples were initially collected in $15 \mathrm{~mL}$, plastic centrifuge cones during the volume reduction and dilution sequences. The volume scales on the cones were used to estimate the quantities of solids present in the samples and to calculate bulk densities $\left(\mathrm{D}_{\text {Bulk }}\right)$. These cones are graduated in $0.5-\mathrm{mL}$ increments from 1 to $14.5 \mathrm{~mL}$ and in $0.1-\mathrm{mL}$ increments from 0 to $1 \mathrm{~mL}$. The accuracy of the volume scales was checked by measuring the weight of reagent water required to fill the cones to the 10-, 12-, and 14-mL marks. The reference densities of water at the measurement temperatures were then used to calculate the actual volumes of water added. Duplicate measurements were performed for each cone. A linear function was derived for each cone relating the volume read from the cone gradations ( $\left.\mathrm{Vol}_{\text {Read }}\right)$ to the 'actual' volume $\left(\mathrm{Vol}_{\text {Corrected }}\right)$ contained. The gravimetric data, reference densities, calculations, and derived correction functions for each cone/boildown sample are presented in Attachment A. 


\section{TEST OPERATIONS AND RESULTS}

\subsection{HOT CELL TEST OPERATIONS}

The basic operations performed and observations made during the boildown concentration, dilution, and sample processing stages are summarized in this section. Transcripts of the hot cell data logs that were used to control the boildown operations and perform the first data processing calculations are presented in Attachment B. Photographs of the samples at various times after being withdrawn from the pot during the boildown are presented in Attachment $\mathrm{C}$.

\subsubsection{Boildown Progress Parameters}

Three parameters were used to monitor the progress of the boildown operations and in postboildown data processing: concentration ratio $(C R)$, percent waste volume reduction (\%WVR), and concentrate bulk density $\left(\mathrm{D}_{\mathrm{Bulk}}\right)$. The $C R$ and $\% \mathrm{WVR}$ are defined as

$$
\begin{gathered}
C R=\mathrm{Vol}_{\text {Start }} / \mathrm{Vol}_{\text {End }} \\
\% \mathrm{WVR}=\left[\left(\mathrm{Vol}_{\text {Start }}-\mathrm{Vol}_{\text {End }}\right) / \mathrm{Vol}_{\text {Start }}\right] \times 100
\end{gathered}
$$

The $C R$ is the factor to which nonvolatile, infinitely soluble species become concentrated over their initial concentrations as the solution volume is reduced $(C R>1)$ or increased $(0<C R<1)$.

Accurate measurement of the concentrate volume during a boildown run is very difficult. Even if this were not so, when multiple samples are withdrawn from the pot the concentrate volume during a boildown is no longer the appropriate value of $\mathrm{Vol}_{\text {End }}$ for calculation of $C R$ or $\% \mathrm{WVR}$.

In practice, a boildown test is planned and controlled using an additive volumes model based on the following assumptions: (1) all solutes are nonvolatile (i.e., only water is removed from the test system), (2) the quantities of all additions to or removals from the system are accurately measured, (3) the volumes of all system components are measured at a common temperature, and (4) the volumes of system components are additive (i.e., $\mathrm{Vol}_{\text {Start }}=\mathrm{Vol}_{\text {End }} \pm \mathrm{Vol}_{\mathrm{H} 2 \mathrm{O}}$ ). Using this model, boildown progress is calculated stepwise. For each step $\mathrm{N}$

$$
\begin{gathered}
\mathrm{Vol}_{\text {Start Step N }}=\mathrm{Vol}_{\text {End Step N-1 }}-\mathrm{Vol}_{\text {Sample N }} \text {, and } \\
C R_{\text {Step N }}=\mathrm{Vol}_{\text {Start Step N }} /\left(\mathrm{Vol}_{\text {Start Step N }} \pm \mathrm{Vol}_{\mathrm{H} 2 \mathrm{O}}\right)
\end{gathered}
$$

The cumulative $C R$ based on the additive volumes model, $C R_{\text {Model }}$, is

$$
C R_{\text {Model }}=C R_{\text {Step } 1} \times C R_{\text {Step } 2} \times C R_{\text {Step } 3} \times \ldots . . \times C R_{\text {Step N }}
$$

and

$$
\% \mathrm{WVR}_{\text {Model }}=\left[\left(C R_{\text {Model }}-1\right) / C R_{\text {Model }}\right] \times 100
$$

In the additive volumes model, the bulk density of the concentrate, $\mathrm{D}_{\text {Model }}$, is a linear function of CR:

$$
\mathrm{D}_{\text {Model }}=\left[\left(\mathrm{D}_{\mathrm{AW}-106 \text { Composite }}-\mathrm{D}_{\mathrm{H} 2 \mathrm{O}}\right) \times C R_{\text {Model }}\right]+\mathrm{D}_{\mathrm{H} 2 \mathrm{O}}
$$


The density of the AW-106 test composite was measured in the 11A-6 hot cell (Table 2-2) and found to be $1.266 \mathrm{~g} / \mathrm{mL}$ at $27.1{ }^{\circ} \mathrm{C}$. This value was used to convert the starting weight of the test composite to a volume. The weights of water removed/added during the boildown were converted to volumes by dividing by the reference density of water at $27.1^{\circ} \mathrm{C}$. The weights of samples removed from the pot were converted to volumes by dividing by the $\mathrm{D}_{\text {Model }} 27.1^{\circ} \mathrm{C}$ values

calculated in the spreadsheet log. The resulting values of $C R_{\text {Model }}{ }^{27.1{ }^{\circ} \mathrm{C}}$ and $\% \mathrm{WVR}_{\text {Model }}{ }^{27.1{ }^{\circ} \mathrm{C}}$ are shown in the boildown log in Table B-1.

\subsubsection{Boildown Test Log}

The following is a chronological log of the AW-106 boildown study, annotated with key observations and descriptions. Where pressures are cited only as integral values, they refer to the nominal target reflux pressures of 40,60 , or 80 Torr, not actual $\mathrm{P}_{\text {Read }}$ or $\mathrm{P}_{\text {Corrected }}$ values.

The boildown concentration and dilution steps were performed in the 11A-6 hot cell; sample processing was performed in the adjacent $11 \mathrm{~A}-5$ hot cell. Typical ambient temperatures in the hot cells were 24 to $27^{\circ} \mathrm{C}$. All test samples were collected in disposable plastic $15-\mathrm{mL}$ centrifuge cones (Section 2.2.4) and processed in these cones through the final separation into centrifuged liquid (C-Liq) and centrifuged solids (C-Slds) fractions.

\section{Boildown Composite Preparation-February 11, 2013}

08:30 The AW-106 boildown test composite was prepared volumetrically, as specified by the 242-A Evaporator POC, using 6 of the 8 grab samples received at the 222-S Laboratory (Section 2.1). A small scattering of fine particulate on the bottom of the amber glass jar was observed in grab samples 6AW-12-03A, -04, and -04A. After consultation with the Evaporator POC, the particles were left in the jars and allowed to transfer into the composite. After composite creation, no appreciable solids were observed in the composite; the particulate either did not transfer or it dissolved in the solution. The final composite was a clear, yellow liquid containing no visible solids.

A 30-mL sample was withdrawn from the composite for analysis, Sample CP. Approximately $13 \mathrm{~mL}$ of the sample was transferred to a $15-\mathrm{mL}$ centrifuge cone and placed in an $18.0{ }^{\circ} \mathrm{C}$ water bath. The remaining $17 \mathrm{~mL}$ was transferred to a labeled sample vial and set aside.

A $20 \mathrm{~mL}$ sample of the composite was also withdrawn and placed in a labeled sample vial, which was set aside for use in a feed mix test with an AP-107 archived sample.

\section{Feed Mix Test-February 13, 2013}

09:20 The 20-mL composite sample withdrawn on 2/11/13 was combined with a 20-mL archived grab sample from AP-107 in a 50-mL centrifuge cone (Section 2.2). After the mixing, there were no signs of gas evolution, solid formation, or temperature change, and the liquid remained clear. 


\section{Boildown Volume Reduction Sequence-February 20, 2013}

08:15 The prepared AW-106 composite, $618.119 \mathrm{~g}$, was transferred to the boildown pot using $100 \mathrm{~mL}$ volumetric flasks. The density of the composite was measured during the transfer (Section 2.1) and determined to be $1.266 \mathrm{~g} / \mathrm{mL}$ at $27.1^{\circ} \mathrm{C}$. The calculated initial volume of the composite test sample was $488.3 \mathrm{~mL}$.

10:40 Boiling pressure/temperature $(\mathrm{P} / \mathrm{T})$ measurements on the composite were completed at 40, 60, and 80 Torr. Boiling was gentle and well behaved. Foam, made of large bubbles, formed in the pot and rose to the bottom of the condensing column (Figure 3-1A). The test composite was a clear, yellow liquid with no visible solids.

11:10 Concentration at 40 Torr was begun (CON-1a). On completion at 12:32, $37.4 \mathrm{~mL}$ of water was removed: $7.66 \% \mathrm{WVR}_{\text {Model }}{ }^{27.1{ }^{\circ} \mathrm{C}}$. P/T measurements at 40,60 , and 80 Torr were completed at 12:50. Boiling was gentle, producing easily broken large bubbles. Composite was a clear, medium yellow liquid with no visible solids.

13:02 Concentration at 40 Torr was begun (CON-1b). On completion at 13:45, $39.4 \mathrm{~mL}$ of water was removed: $15.73 \% \mathrm{WVR}_{\text {Model }}{ }^{27.1^{\circ} \mathrm{C}}$. P/T measurements at 40,60 , and 80 Torr were completed at 14:04. Boiling was gentle and well behaved with quickly popping bubbles (Figure 3-1B). Composite was a clear, yellow liquid with no visible solids.

\section{Figure 3-1. Tank 241-AW-106 Composite during the Early Stages of the Volume} Reduction.
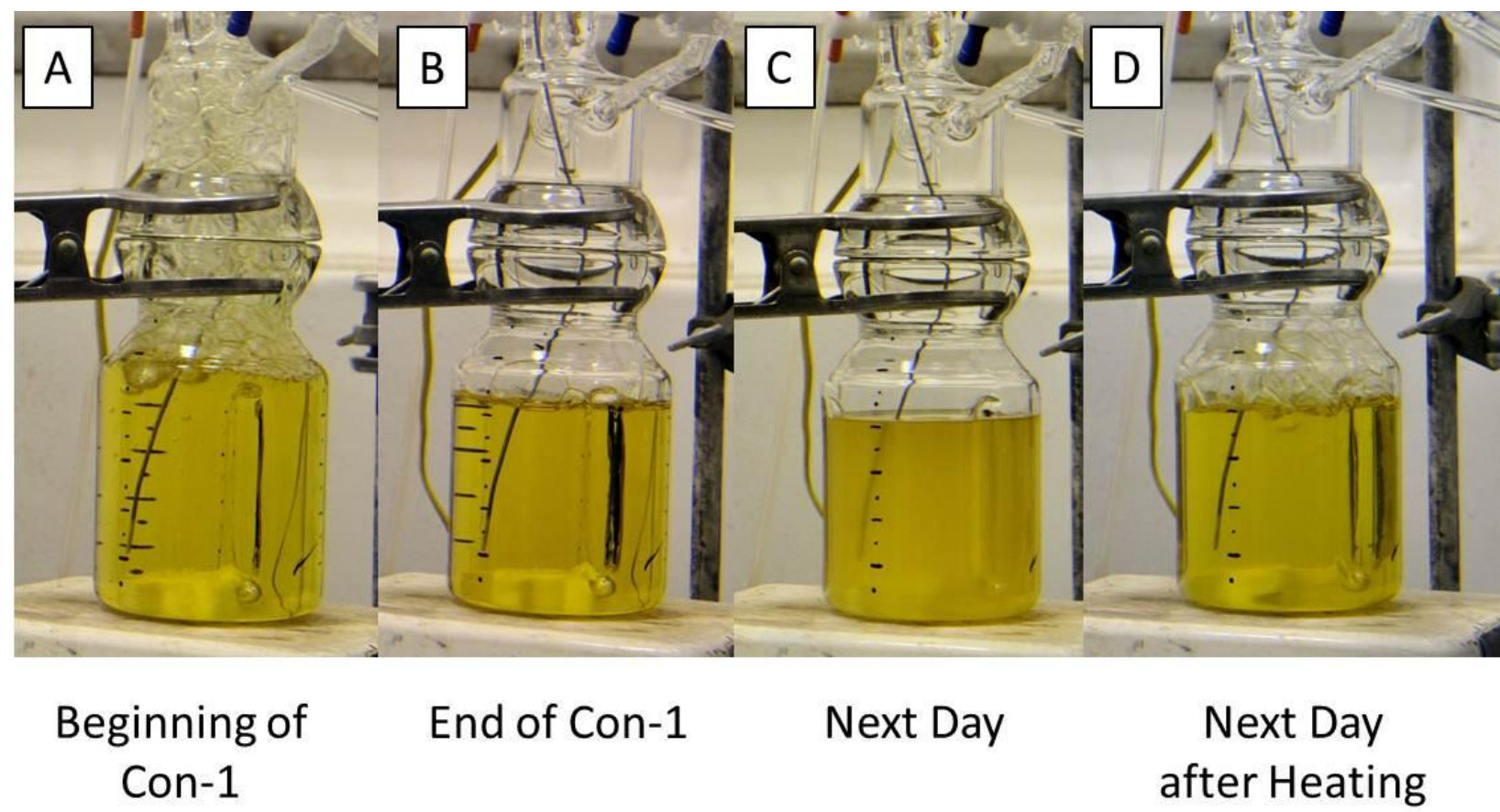

14:20 Sample CON-1 was drawn from the pot $(12.5 \mathrm{~mL})$ and transferred to Centrifuge Cone 8. A photograph of the sample was taken after the pot was reconnected to the still head. 
14:30 Boildown was halted. The heat to the boildown pot was turned off, the pot was vented to hot cell ambient pressure, and the magnetic stirrer was left on.

\section{Boildown Volume Reduction Sequence-February 21, 2013}

07:30 Overnight at hot cell ambient pressure and temperature $\left(26.4{ }^{\circ} \mathrm{C}\right)$, the test composite became cloudy and was partially opaque (Figure 3-1C).

07:53 Composite reflux established at 40 Torr $\left(38.0^{\circ} \mathrm{C}\right)$. The cloudiness disappeared and the solution became clear. Boiling was well behaved with no visible solids (Figure 3-1D).

07:56 Concentration at 40 Torr was begun (CON-2). On completion at 08:25, $37.7 \mathrm{~mL}$ of water was removed: $23.69 \% \mathrm{WVR}_{\text {Model }}{ }^{27.1^{\circ} \mathrm{C}}$. P/T measurements at 40, 60, and 80 Torr were completed at 08:39. Boiling was steady, gentle, and well behaved with large bubbles breaking at a single layer (Figure 3-2A). The liquid was medium yellow with no visible solids.

08:50 Sample CON-2 was drawn from the pot $(12.5 \mathrm{~mL})$ and transferred to Centrifuge Cone 11. A photograph of the sample was taken after the pot was reconnected to the still head.

09:12 Concentration at 40 Torr was begun (CON-3). On completion at 10:02, $26.7 \mathrm{~mL}$ of water was removed: $29.53 \% \mathrm{WVR}_{\text {Model }}{ }^{27.1^{\circ} \mathrm{C}}$. P/T measurements at 40, 60, and 80 Torr were completed at 10:15. Boiling was steady and gentle, no foaming, with a single layer of popping bubbles. The liquid was medium yellow with no visible solids (Figure 3-2B).

Figure 3-2. Tank 241-AW-106 Composite during Mid Stages of the Volume Reduction.

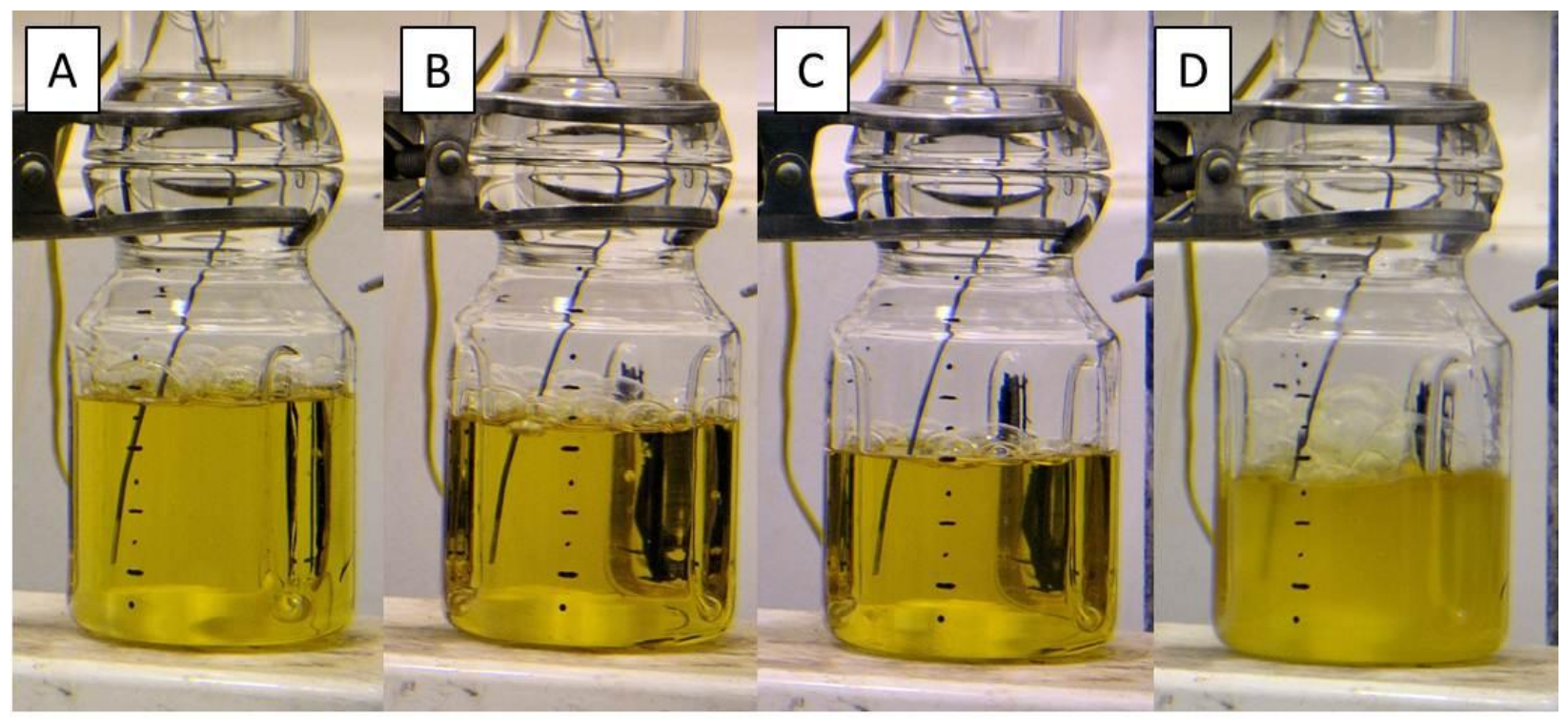

End of Con-2 End of Con-3 End of Con-4

Con-5 Solids Formation 
10:27 Sample CON-3 was drawn from the pot (12.5 mL) and transferred to Centrifuge Cone 3. A photograph of the sample was taken after the pot was reconnected to the still head.

10:45 Concentration at 40 Torr was begun (CON-4). On completion at 11:16, $25.5 \mathrm{~mL}$ of water was removed: $35.32 \% \mathrm{WVR}_{\text {Model }}{ }^{27.1^{\circ} \mathrm{C}}$. P/T measurements at 40, 60, and 80 Torr were completed at 11:24. Boiling was steady and gentle with larger, quickly popping bubbles one layer thick. The liquid was medium yellow with no visible solids (Figure 3-2C).

11:37 Sample CON-4 was drawn from the pot $(12.4 \mathrm{~mL})$ and transferred to Centrifuge Cone 4. A photograph of the sample was taken after the pot was reconnected to the still head.

11:54 Concentration at 40 Torr was begun (CON-5). After $16.9 \mathrm{~mL}$ of water was removed (12:15), the composite become cloudy as solids began to form (Figure 3-2D). The concentration step was interrupted and P/T measurements taken. Solids remained for all three measurements, and the concentration step was restarted. On completion at 12:30, $21.4 \mathrm{~mL}$ of water was removed: $40.42 \% \mathrm{WVR}_{\text {Model }} 27.1^{\circ} \mathrm{C} . \mathrm{P} / \mathrm{T}$ measurements at 40,60 , and 80 Torr were completed at 12:38. Boiling was well behaved with a single layer of bubbles. The liquid was very cloudy and yellow (Figure 3-3A).

12:47 Sample CON-5 was drawn from the pot $(12.3 \mathrm{~mL})$ and transferred to Centrifuge Cone 5. A photograph of the sample was taken after the pot was reconnected to the still head.

13:04 Concentration at 40 Torr was begun (CON-6). On completion at 13:18, $19.5 \mathrm{~mL}$ of water was removed: $45.31 \% \mathrm{WVR}_{\text {Model }}{ }^{27.1^{\circ} \mathrm{C}}$. P/T measurements at 40, 60, and 80 Torr were completed at 13:25. Boiling was steady, well behaved, and without foaming. The composite was completely opaque, and the loading of fine, white solids in the slurry was noticeably greater (Figure 3-3B).

Figure 3-3. Tank 241-AW-106 Composite During the End Stages of the Volume Reduction.

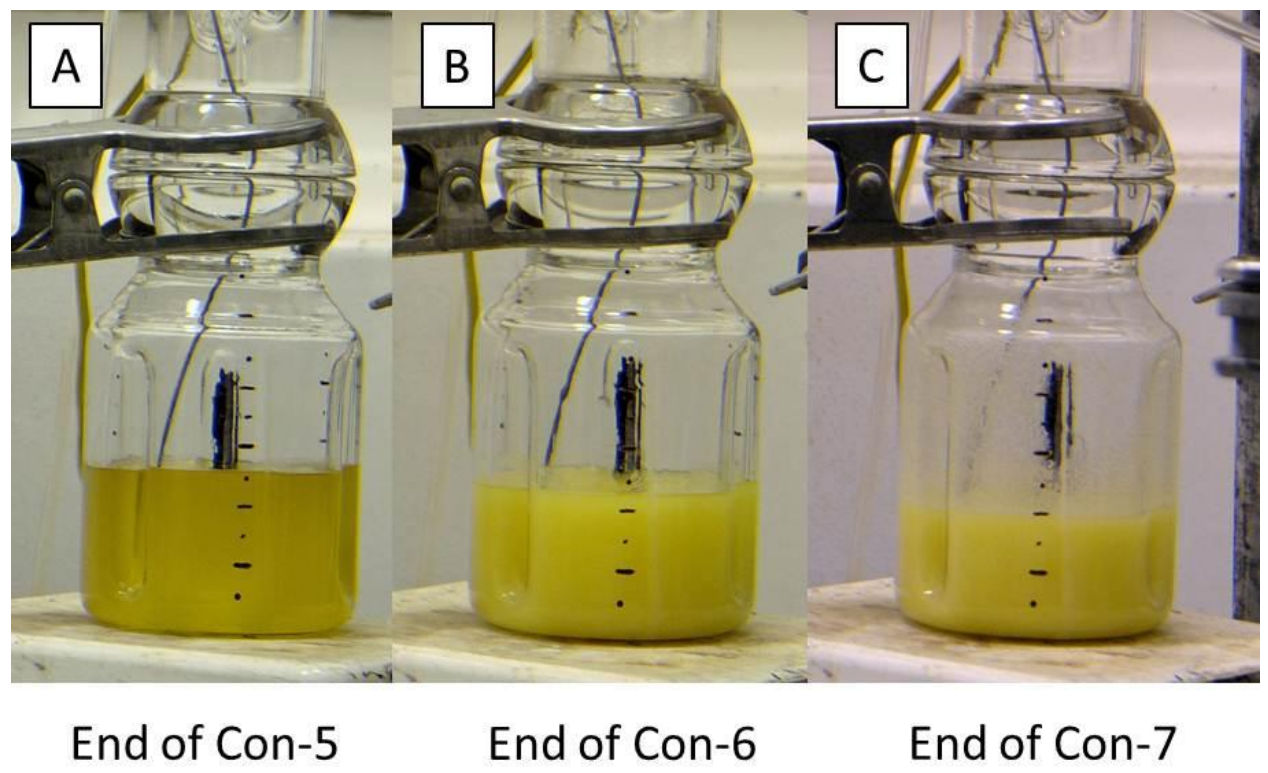


13:36 Sample CON-6 was drawn from the pot (12.4 mL) and transferred to Centrifuge Cone 14. A photograph of the sample was taken after the pot was reconnected to the still head.

13:57 Concentration at 80 Torr was begun (CON-7). On completion at 14:08, $18.1 \mathrm{~mL}$ of water was removed: $50.10 \% \mathrm{WVR}_{\text {Model }}{ }^{27.1{ }^{\circ} \mathrm{C}}$. P/T measurements at 40, 60, and 80 Torr were completed at 14:13. This was the end-point of the boildown concentration. The test composite was a thick, milky, yellow slurry of fine, white solids (Figure 3-3C).

14:23 Sample CON-7 was drawn from the pot $(12.4 \mathrm{~mL})$ and transferred to Centrifuge Cone 13. A photograph of the sample was taken after the pot was reconnected to the still head.

\section{End-point Slurry Dilution Sequence—February 21, 2013}

14:50 Dilution step DIL-1 was completed by adding $52.8 \mathrm{~mL}$ of water back to the pot: $35.10 \% \mathrm{WVR}_{\text {Model }}{ }^{27.1{ }^{\circ} \mathrm{C}}$. Reflux of the test slurry at 60 Torr was established and a P/T measurement completed at 15:00. Boiling was well behaved with no foaming. The concentration of solids was visibly reduced but the test slurry remained cloudy (Figure 3-4A).

15:06 Sample DIL-1 was drawn from the pot (12.3 mL) and transferred to Centrifuge Cone 15. A photograph of the sample was taken after the pot was reconnected to the still head.

15:26 Dilution step DIL-2 was completed by adding $35.3 \mathrm{~mL}$ of water back to the pot: $24.49 \% \mathrm{WVR}_{\text {Model }} 27 .{ }^{\circ} \mathrm{C}$. Reflux of the test slurry at 60 Torr was established, and a P/T measurement was completed at 15:38. Boiling was well behaved with no foaming. The composite remained cloudy (Figure 3-4B).

16:00 Sample DIL-2 was drawn from the pot $(12.5 \mathrm{~mL})$ and transferred to Centrifuge Cone 10. A photograph of the sample was taken after the pot was reconnected to the still head.

Figure 3-4. Tank 241-AW-106 Composite during the Volume Dilution.

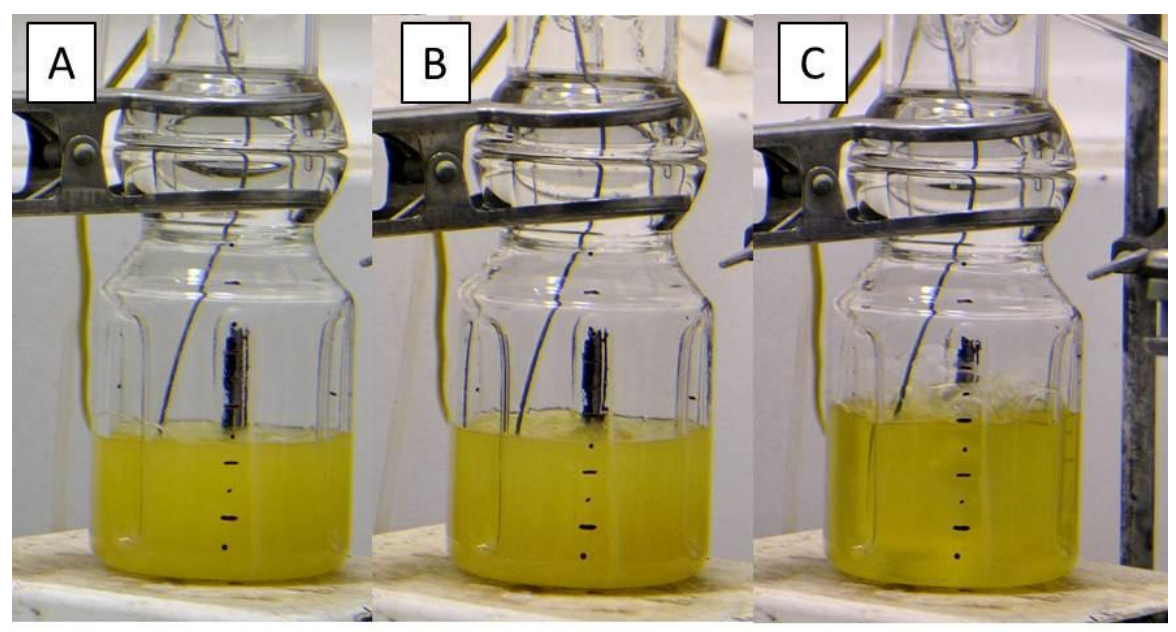

End of Con-5 End of Con-6 End of Con-7 
16:10 Dilution step DIL-3 was completed by adding $46.8 \mathrm{~mL}$ of water back to the pot:

$9.71 \% \mathrm{WVR}_{\text {Model }}{ }^{27.1^{\circ} \mathrm{C}}$. Reflux of the test slurry at 60 Torr was established, and a P/T measurement was completed at 16:23. Boiling was well behaved with no foaming. The test slurry was partially cloudy (Figure 3-4C).

16:33 Sample DIL-3 was drawn from the pot $(12.6 \mathrm{~mL})$ and transferred to Centrifuge Cone 2. A photograph of the sample was taken after the pot was reconnected to the still head.

16:34 Boildown was terminated. The reconstituted composite was transferred to a glass jar for temporary storage. The weight of the remaining composite was $341.82 \mathrm{~g}$.

\subsection{HOT CELL SAMPLE PROCESSING}

\subsubsection{Initial Sample Processing}

February 22, 2013: The boildown samples were transferred to Hot Cell 11A-5. By the morning of this day, Sample CON-1 had been sitting at hot cell ambient temperature for $42 \mathrm{hrs}$, and Samples CON-2 through CON-7 and DIL-1 through DIL-3 had been sitting for 18-24 hrs. All 10 cones were weighed and photographed (Attachment $\mathrm{C}$ ). The total sample volume and the estimated volume of any settled solids (S-Slds) were recorded for each sample.

All 10 sample cones and the jar containing the final slurry recovered from the boildown pot were suspended in a water bath cooled to $18.0^{\circ} \mathrm{C}$.

February 27, 2013: Starting at 10:12, each boildown sample was removed from the $18.0^{\circ} \mathrm{C}$ water bath and photographed (Attachment C). The total sample volume, S-Slds volume, and visual appearance of the S-Slds were recorded for each sample. The samples were then returned to the water bath.

The appearance and settling behavior observed in boildown Samples CON-1 through CON-7 and DIL-1 through DIL-3 are summarized in Table 3-1. Descriptions of the samples shortly after removal from the pot, after at least $18 \mathrm{hrs}$ at hot cell ambient temperature and after $\sim 5$ days at $18.0^{\circ} \mathrm{C}$, are included.

\subsubsection{Final Sample Processing}

February 27, 2013: Starting at 13:30, the boildown samples were removed from the $18.0^{\circ} \mathrm{C}$ water bath and centrifuged for 10 minutes at $\sim 1000 \times g$. The samples were then returned to the water bath. Photos were taken (Attachment C). 
Table 3-1. Appearance of Settled Solids in Boildown Samples. (2 sheets)

\begin{tabular}{|c|c|c|}
\hline Sample & \%WVR & Appearance of Settled Solids \\
\hline $\mathrm{CON}-1$ & 15.7 & $\begin{array}{l}\text { <1 hr after sampling: The pot sample was a clear, yellow liquid with no visible solids. } \\
\mathbf{4 2} \text { hrs at } \mathbf{2 4 . 4}{ }^{\circ} \mathrm{C} \text { : The sample was a clear, yellow liquid with no settled solids. Some } \\
\text { small solids were attached to the cone wall. } \\
\mathbf{5} \text { days at } 18{ }^{\circ} \mathbf{C} \text { : The sample was a clear, yellow liquid with no settled solids. Some small } \\
\text { solids were attached to the cone wall. }\end{array}$ \\
\hline $\mathrm{CON}-2$ & 23.7 & $\begin{array}{l}\text { <1 hr after sampling: The pot sample was a clear, yellow liquid with no visible solids. } \\
\mathbf{2 4} \text { hrs at } 24.4^{\circ} \mathrm{C} \text { : The sample was a clear, yellow liquid with no settled solids. Some } \\
\text { small, granular solids were attached to the lower cone wall. } \\
\mathbf{5} \text { days at } 18{ }^{\circ} \mathrm{C} \text { : The sample was a clear, yellow liquid with no settled solids. Some small, } \\
\text { granular solids were attached to the lower cone wall. }\end{array}$ \\
\hline $\mathrm{CON}-3$ & 29.5 & $\begin{array}{l}\text { <1 hr after sampling: The pot sample was a clear, yellow liquid with no visible solids. } \\
\mathbf{2 3} \text { hrs at } 24.4^{\circ} \mathrm{C} \text { : The sample was a clear, yellow liquid with no settled solids. Small, } \\
\text { clear, granular solids were attached to the lower cone wall. } \\
5 \text { days at } 18{ }^{\circ} \mathrm{C} \text { : The sample was a clear, yellow liquid with no settled solids. Small, clear, } \\
\text { granular solids were attached to the cone wall with a greater number near the bottom of the } \\
\text { cone. }\end{array}$ \\
\hline $\mathrm{CON}-4$ & 35.3 & $\begin{array}{l}\text { <1 hr after sampling: The pot sample was a clear, yellow liquid with no visible solids. } \\
\mathbf{2 2} \text { hrs at } 24.4{ }^{\circ} \text { C: The sample was a clear, yellow liquid with a trace of settled solids. } \\
\text { There was a continuous layer of clear, granular particles adhered to the lower half of the } \\
\text { cone wall. } \\
\mathbf{5} \text { days at } 18{ }^{\circ} \mathbf{C} \text { : The sample was a clear, yellow liquid with a trace of settled solids. There } \\
\text { was a continuous layer of clear, granular particles adhered to the lower half of the cone } \\
\text { wall. }\end{array}$ \\
\hline CON-5 & 40.4 & $\begin{array}{l}<\mathbf{~ h r} \text { after sampling: The pot sample was a cloudy, yellow liquid with some settled, fine } \\
\text { solids filling } \sim 0.1 \mathrm{~mL} \text { of the bottom of the cone. } \\
\mathbf{2 1} \text { hrs at } \mathbf{2 4 . 4}{ }^{\circ} \mathrm{C} \text { : The sample was a clear, yellow liquid with some settled, fine solids } \\
\text { filling } \sim 0.2 \mathrm{~mL} \text { of the bottom of the cone. } \\
\mathbf{5} \text { days at } 18{ }^{\circ} \mathbf{C} \text { : The sample was a clear, yellow liquid with some settled, fine solids. No } \\
\text { significant change in the appearance of the S-Slds. Particles in the S-Slds were too small to } \\
\text { observe any morphology. }\end{array}$ \\
\hline CON-6 & 45.3 & $\begin{array}{l}\mathbf{1} \mathbf{h r} \text { after sampling: The pot sample was a cloudy, yellow liquid with flocculent solids } \\
\text { filling } \sim 9 \mathrm{~mL} \text { of the cone. } \\
\mathbf{2 0} \text { hrs at } \mathbf{2 4 . 4}{ }^{\circ} \mathbf{C} \text { : The sample was a clear, yellow liquid with flocculent solids filling } \\
\sim 6 \mathrm{~mL} \text { of the cone. } \\
\mathbf{5} \text { days at } \mathbf{1 8}{ }^{\circ} \mathrm{C} \text { : No significant change in the appearance of the S-Slds. Particles in the } \\
\text { S-Slds were too small to observe any morphology. }\end{array}$ \\
\hline $\mathrm{CON}-7$ & 50.1 & $\begin{array}{l}\mathbf{1} \text { hr after sampling: This was the end-point slurry sample. The cone was completely } \\
\text { filled with suspended solids. } \\
\mathbf{2 0} \text { hrs at } \mathbf{2 4 . 4}{ }^{\circ} \mathbf{C} \text { : The sample was a clear, yellow liquid with fine solids filling } \sim 6 \mathrm{~mL} \text { of } \\
\text { the cone. One large pyramidal crystal on cone wall. } \\
\mathbf{5} \text { days at } \mathbf{1 8}{ }^{\circ} \mathrm{C} \text { : No significant change in the appearance of the S-Slds. Particles in the } \\
\text { S-Slds were too small to observe any morphology. }\end{array}$ \\
\hline
\end{tabular}


Table 3-1. Appearance of Settled Solids in Boildown Samples. (2 sheets)

\begin{tabular}{|c|c|c|}
\hline Sample & $\% \mathbf{W V R}$ & Appearance of Settled Solids \\
\hline DIL-1 & 35.1 & $\begin{array}{l}<\mathbf{1 ~ h r} \text { after sampling: The pot sample was a cloudy, yellow liquid with some settled, fine } \\
\text { solids filling }<0.1 \mathrm{~mL} \text { of the bottom of the cone. } \\
\mathbf{1 9} \text { hrs at } 24.4{ }^{\circ} \mathbf{C} \text { : The sample was a clear, yellow liquid with some settled, fine solids } \\
\text { filling } \sim 1.5 \mathrm{~mL} \text { of the bottom of the cone. } \\
\mathbf{5} \text { days at } 18{ }^{\circ} \mathrm{C} \text { : There was no significant change in the appearance of the S-Slds. } \\
\text { Particles in the S-Slds were too small to observe any morphology. Some additional granular } \\
\text { solids on cone wall. }\end{array}$ \\
\hline DIL-2 & 24.5 & $\begin{array}{l}\text { <1 hr after sampling: The pot sample was a clear, yellow liquid with flocculent solids } \\
\text { filling } \sim 2 \mathrm{~mL} \text { of the cone. } \\
\mathbf{1 8} \text { hrs at } 24.4{ }^{\circ} \mathbf{C} \text { : The sample was a clear, yellow liquid with some settled, fine solids } \\
\text { filling } \sim 1 \mathrm{~mL} \text { of the bottom of the cone. } \\
\mathbf{5} \text { days at } 18{ }^{\circ} \mathrm{C} \text { : There was no significant change in the appearance of the S-Slds. } \\
\text { Particles in the S-Slds were too small to observe any morphology. Some additional solids } \\
\text { on cone wall. }\end{array}$ \\
\hline DIL-3 & 9.7 & $\begin{array}{l}\text { <1 hr after sampling: The pot sample was slightly cloudy with no settled solids. } \\
\mathbf{1 8} \text { hrs at } 24.4{ }^{\circ} \mathrm{C} \text { : The sample was a clear, yellow liquid with some settled, fine solids } \\
\text { filling } \sim 0.5 \mathrm{~mL} \text { of the bottom of the cone. } \\
\mathbf{5} \text { days at } 18{ }^{\circ} \mathrm{C} \text { : There was no significant change in the appearance of the S-Slds. } \\
\text { Particles in the } \mathrm{S} \text {-Slds were too small to observe any morphology. Some additional solids } \\
\text { were on the cone wall. }\end{array}$ \\
\hline
\end{tabular}

March 4, 2013: Boildown Samples CON-1 through CON-7 and DIL-1 through DIL-3 were removed from the $18.0{ }^{\circ} \mathrm{C}$ water bath, centrifuged for 10 minutes at $\sim 1000 \times g$, and then returned to the bath. After all 10 samples had been through the second centrifuge cycle, they were photographed.

Densities of the C-Liq were measured by transferring $1.0 \mathrm{~mL}$ aliquots to a tared glass vial via a positive displacement pipette. The liquid was then returned to the centrifuge cone, and the cone placed back into the $18.0^{\circ} \mathrm{C}$ water bath.

March 5, 2013: The centrifuged supernatant liquid C-Liq was decanted into labeled sample vials for all of the 10 samples. The C-Slds were then collected for solid phase characterization (SPC).

Due to the small quantities of C-Slds present, the solids recovered from samples CON-3 through CON-5 were combined. A small quantity of C-Liq from Sample CON-5 was used to facilitate recovery and transfer of the $\mathrm{C}$-Slds to a sample vial.

The C-Slds from Sample CON-6 were recovered and transferred to a sample vial.

The C-Slds from Sample CON-7 were recovered and transferred to a sample vial. Due to the compacted nature of the solids, some C-Liq from CON-7 was used to transfer the solids. 
Due to the limited amount of C-Slds in Sample DIL-3, the solids from step DIL-3 were collected from the S-Slds in the bottom of the jar containing the final slurry set aside at the conclusion of the boildown test.

The final identifications of the AW-106 boildown study samples are tabulated in Table 3-2.

Table 3-2. Identification of Tank 241-AW-106 Boildown Samples.

\begin{tabular}{|c|c|c|}
\hline \multirow{2}{*}{ Test Sample } & \multicolumn{2}{|c|}{ 222-S Sample Number S13T00- } \\
\cline { 2 - 3 } Test Composite & Liquid & Solids \\
\hline CP & -1220 & \multicolumn{1}{|c|}{} \\
\cline { 2 - 3 } & -1221 & \multicolumn{1}{|c|}{} \\
\hline Volume Reduction & \multicolumn{2}{|c|}{} \\
\hline CON-1 & -1234 & - \\
\hline CON-2 & -1235 & -1244 \\
\hline CON-3 & -1236 & \\
\hline CON-4 & -1237 & -1245 \\
\hline CON-5 & -1238 & -1246 \\
\hline CON-6 & -1239 & \\
\hline CON-7 & -1242 & -1254 \\
\hline Dilution of End-point Slurry & - \\
\hline DIL-1 & -1251 & - \\
\hline DIL-2 & -1252 & \\
\hline DIL-3 & -1253 & \\
\hline
\end{tabular}

March 8, 2013: The 12 samples of boildown liquids were loaded out of the 11A hot cells and submitted to 222-S Laboratory for analysis. The 4 samples of boildown sample solids were loaded out and submitted for SPC measurements. 


\subsubsection{Densities of Boildown Sample Liquids}

The densities of the boildown C-Liq samples were measured before the samples were loaded out of the hot cells and submitted to the 222-S Laboratory for analysis. To perform the measurements, the temperature of the C-Liq samples were first measured (the temperatures of the samples were $18.0{ }^{\circ} \mathrm{C}$ due to the use of the water bath). Using a positive-displacement pipette, a 1.00-mL portion of each liquid was transferred to a sample vial and weighed. A second $1.00 \mathrm{~mL}$-sample portion was then added to the vial and weighed. The average C-Liq density was calculated. The test liquid was then returned to the parent sample using a disposable pipette.

The density of demineralized water $\left(24.2^{\circ} \mathrm{C}\right)$ was measured before and after the C-Liq sample measurements. All the measured densities were within $1 \%$ of the reference values for pure water.

\subsection{FINAL VOLUME AND WEIGHT DATA}

The results of gravimetric and volumetric measurements on the boildown samples are summarized in Table 3-3.

The total S-Slds and C-Slds volumes at hot cell ambient temperature $\left(24.4{ }^{\circ} \mathrm{C}\right)$ and at $18.0{ }^{\circ} \mathrm{C}$ are based on examination of sample photographs. Apparent volumes $\left(\mathrm{Vol}_{\text {Read }}\right)$ were measured as accurately as possible from enlargements of sample photographs. The $\mathrm{Vol}_{\text {Read }}$ values were then converted to $\mathrm{Vol}_{\text {Corrected }}$ volumes using the cone calibration functions in Attachment A.

The vol\% S-Slds and vol\% C-Slds in each sample are the apparent volumes of the solids divided by the corrected total volumes at $18.0{ }^{\circ} \mathrm{C}$ or at hot cell ambient temperature with the results multiplied by 100 .

The $\mathrm{D}_{\text {Bulk }}$ values are the weights of the bulk samples divided by the total sample volumes measured at the indicated temperature.

The $\mathrm{D}_{\mathrm{Liq}}{ }^{18^{\circ} \mathrm{C}}$ measurement values in Table 3-3 are the results of densities measurements of the C-Liq portions of the boildown samples as discussed in Section 3.2.3. Each $\mathrm{D}_{\text {Liq }}{ }^{1{ }^{\circ} \mathrm{C}}$ calculation value is the weight of the C-Liq decanted from a sample divided by the estimated difference between the total and C-Slds volumes while still in the $15-\mathrm{mL}$ centrifuge cone at $18.0{ }^{\circ} \mathrm{C}$. The $\mathrm{D}_{\mathrm{Liq}}{ }^{222-\mathrm{S}}$ values are the densities of the C-Liq samples measured by the 222-S Laboratory personnel. 
Table 3-3. Gravimetric and Volumetric Data for Tank 241-AW-106 Boildown Samples.

\begin{tabular}{|c|c|c|c|c|c|c|c|c|c|c|c|}
\hline Test Sample & $\mathbf{C P}$ & CON 1 & CON 2 & CON 3 & CON 4 & CON 5 & CON 6 & CON 7 & DIL 1 & DIL 2 & DIL 3 \\
\hline$\% \mathrm{WVR}^{18^{\circ} \mathrm{Ca}}$ & 0.0 & 15.5 & 23.3 & 29.0 & 34.7 & 39.3 & 44.1 & 48.7 & 34.4 & 24.1 & 10.0 \\
\hline$C R^{18^{\circ} \mathrm{Ca}}$ & 1.00 & 1.18 & 1.30 & 1.41 & 1.53 & 1.65 & 1.79 & 1.95 & 1.52 & 1.32 & 1.11 \\
\hline Total Wt (g) & 16.275 & 16.466 & 16.856 & 17.207 & 17.552 & 17.882 & 18.466 & 19.006 & 17.386 & 16.951 & 16.308 \\
\hline Wt Wet $18{ }^{\circ} \mathrm{C}$ C-Slds (g) & 0.000 & 0.151 & 0.186 & 0.260 & 0.352 & 1.167 & 5.071 & 6.370 & 0.981 & 0.668 & 0.213 \\
\hline Wt $18{ }^{\circ} \mathrm{C}$ C-Liq (g) & 16.275 & 16.315 & 16.670 & 16.947 & 17.200 & 16.715 & 13.395 & 12.636 & 16.405 & 16.283 & 16.095 \\
\hline Total $\mathrm{Vol}^{\text {Ambient }}(\mathrm{mL})$ & 12.80 & 12.55 & 12.57 & 12.61 & 12.56 & 12.54 & 12.73 & 12.78 & 12.44 & 12.52 & 12.49 \\
\hline $\mathrm{Vol}^{\text {Ambient }} \mathrm{S}$-Slds (mL) & 0.00 & 0.00 & 0.00 & 0.00 & 0.00 & 0.25 & 6.50 & 6.20 & 1.50 & 1.20 & 0.45 \\
\hline Total $\mathrm{Vol}^{18^{\circ} \mathrm{C}}(\mathrm{mL})$ & 12.85 & 12.54 & 12.55 & 12.57 & 12.54 & 12.56 & 12.67 & 12.71 & 12.44 & 12.59 & 12.55 \\
\hline $\operatorname{Vol}^{18^{\circ} \mathrm{C}}$ S-Slds $(\mathrm{mL})$ & 0.00 & 0.00 & 0.00 & 0.00 & 0.00 & 0.28 & 6.50 & 6.10 & 1.50 & 1.20 & 0.40 \\
\hline $\mathrm{Vol}^{18{ }^{\circ} \mathrm{C}} \mathrm{C}-\mathrm{Slds}(\mathrm{mL})$ & 0.00 & 0.07 & 0.10 & 0.15 & 0.19 & 0.40 & 3.20 & 4.00 & 0.55 & 0.32 & 0.10 \\
\hline $\operatorname{Vol}^{18{ }^{\circ} \mathrm{C}} \mathrm{C}$-Liq $(\mathrm{mL})$ & 12.85 & 12.47 & 12.45 & 12.42 & 12.35 & 12.16 & 9.47 & 8.71 & 11.89 & 12.27 & 12.45 \\
\hline Vol\% S-Slds at Ambient T & 0.00 & 0.00 & 0.00 & 0.00 & 0.00 & 1.99 & 51.06 & 48.51 & 12.06 & 9.58 & 3.60 \\
\hline Vol\% S-Slds at $18^{\circ} \mathrm{C}$ & 0.00 & 0.00 & 0.00 & 0.00 & 0.00 & 2.23 & 51.30 & 47.99 & 12.06 & 9.53 & 3.19 \\
\hline Vol\% C-Slds at $18^{\circ} \mathrm{C}$ & 0.00 & 0.56 & 0.80 & 1.19 & 1.52 & 3.18 & 25.26 & 31.47 & 4.42 & 2.54 & 0.80 \\
\hline Wt $\%$ Wet $18{ }^{\circ} \mathrm{C} \mathrm{C}$-Slds & 0.000 & 0.917 & 1.103 & 1.511 & 2.005 & 6.526 & 27.461 & 33.516 & 5.642 & 3.941 & 1.306 \\
\hline $\mathrm{D}_{\text {Bulk }}{ }^{18^{\circ} \mathrm{C}}(\mathrm{g} / \mathrm{mL})$ & 1.267 & 1.313 & 1.343 & 1.369 & 1.400 & 1.424 & 1.457 & 1.495 & 1.398 & 1.346 & 1.299 \\
\hline $\mathrm{D}_{\text {Liq }}{ }^{18^{\circ} \mathrm{C}}(\mathrm{g} / \mathrm{mL})$ measured & 1.267 & 1.318 & 1.348 & 1.371 & 1.400 & 1.421 & 1.427 & 1.431 & 1.393 & 1.349 & 1.303 \\
\hline $\mathrm{D}_{\text {Liq }}{ }^{18^{\circ} \mathrm{C}}(\mathrm{g} / \mathrm{mL})$ calculated & 1.267 & 1.308 & 1.339 & 1.364 & 1.393 & 1.375 & 1.414 & 1.451 & 1.380 & 1.327 & 1.293 \\
\hline $\mathrm{D}_{\mathrm{Liq}}{ }^{222-\mathrm{S}}(\mathrm{g} / \mathrm{mL})$ & 1.250 & 1.291 & 1.317 & 1.336 & 1.356 & 1.392 & 1.366 & 1.380 & 1.347 & 1.313 & 1.368 \\
\hline
\end{tabular}

$\mathrm{CP}=$ initial test composite

${ }^{\mathrm{a}}$ Actual test values of boildown progress parameters as calculated in Section 5.1.2. 
The $\mathrm{D}_{\mathrm{Liq}}{ }^{10^{\circ} \mathrm{C}}$ measurement values and the density values reported by the $222-\mathrm{S}$ Laboratory are presented graphically in Figure 3-5. In this figure, and all other plots in this report, values for the initial test composite (CP) and the volume reduction sequence samples (CON-1 to CON-7) are displayed with solid data markers; values for the dilution sequence samples (DIL-1 to DIL-3) are displayed with hollow data markers of the same shape and border color.

The plots of the $\mathrm{D}_{\mathrm{Liq}}{ }^{1{ }^{\circ} \mathrm{C}}$ and $\mathrm{D}_{\mathrm{Liq}}{ }^{222-\mathrm{S}}$ values both display similar trends: an increasing density which begins to plateau when solids formed in the composite. The values reported by the 222-S Laboratory have a lower density. This could be a systematic error (the temperature of the 222-S Laboratory data were not recorded). In contrast, the $\mathrm{D}_{\mathrm{Liq}}{ }^{\circ{ }^{\circ} \mathrm{C}}$ values follow the trend line well, were all acquired at the reported temperature, and do not have any outliers suggesting that they better represents the actual densities of the C-Liq in the samples.

Figure 3-5. Density of Sample Liquids versus Tank 241-AW-106 Boildown Progress.

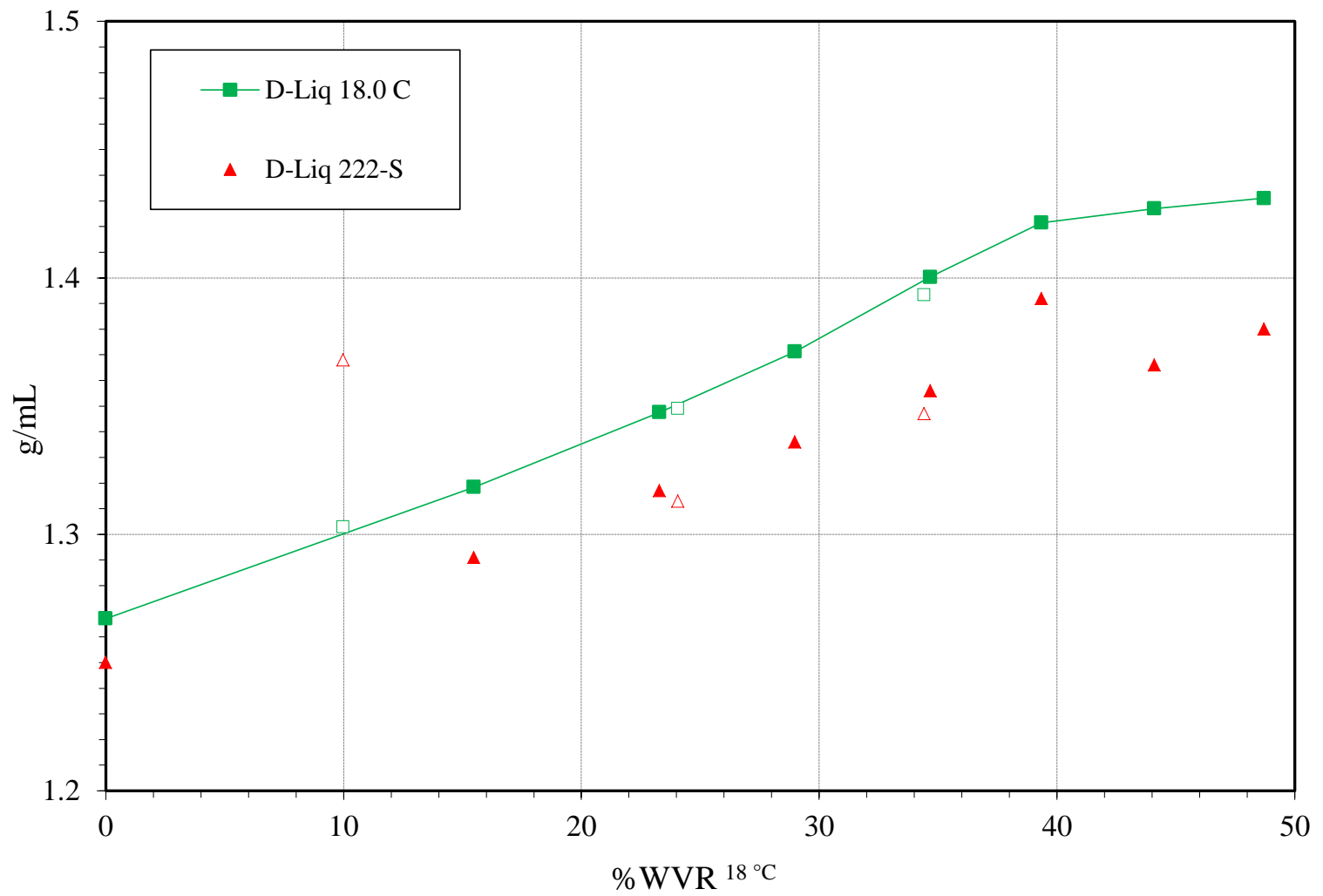




\section{LABORATORY ANALYSIS OF BOILDOWN SAMPLES}

The liquid samples created during the AW-106 boildown were submitted to the 222-S Laboratory for chemical analysis. These analyses were performed by the 222-S analytical contractor, Advanced Technologies and Laboratories International, Inc. (ATL). A transcript of the analysis results is presented in Attachment D.

The analysis results are summarized in Table 4-1. Analysis results for all priority analytes are presented. Other (opportunistic) analytes for which none of the analysis results exceeded the reported detection limit have been omitted from the table.

The sum of the total organic carbon (TOC) and total inorganic carbon (TIC) analysis results compares well ( $<2 \%$ error) to all three measurements of the total carbon (Total C) confirming the accuracy of these measurements.

The concentrations of four organic acid anions - formate, acetate, glycolate, and oxalate — in the sample liquids were analyzed by ion chromatography (IC). The concentrations of organic carbon represented by the reported concentrations of the anions were calculated and subtracted from the reported TOC values measured by acid sparging/persulfate oxidation/coulometry. The differences are tabulated as $\triangle T O C$. The reported TOC is $42-71 \%$ greater than the sum of the carbon from the organic acid anions. Although this unaccounted organic carbon was also similarly observed in the previous AP-107 boildown (LAB-RPT-12-00008,), the cause for this discrepancy is unknown although it is likely that other organic compounds are in the waste.

The oxalate concentration drops below the quantitative detection limit for the CON-5 sample (where solids first formed) suggesting that oxalate precipitated from solution and did not go back into solution during the dilution sequence.

The concentrations of phosphate $\left(\mathrm{PO}_{4}{ }^{3-}\right)$ in the liquid samples measured with IC fell below the detection limit for all samples except for CP and DIL-3. However, the phosphate number was captured by using the reported concentrations of $\mathrm{P}$, measured with inductively coupled plasmaatomic emission spectrometry (ICP-AES), and then recalculated as $\mathrm{PO}_{4}{ }^{3-}$. The calculated $\mathrm{PO}_{4}{ }^{3-}$ trend also shows that the highest concentrations were in the CP and DIL-3 samples similar to the two measured $\mathrm{PO}_{4}{ }^{3-}$ concentrations.

The concentrations of sulfate $\left(\mathrm{SO}_{4}{ }^{2-}\right)$ in the liquid samples measured with IC can be compared with concentrations of $\mathrm{S}$ measured with ICP-AES and then recalculated as $\mathrm{SO}_{4}{ }^{2-}$. The calculated ICP-AES SO ${ }_{4}{ }^{2-}$ values correspond rather well with the measured sulfate $(<10 \%)$ for all samples except CON-7, DIL-1, and DIL-2 (15 to 20\%).

The ratio of the total, calculated positive charge to the total, calculated negative charge, referred to as a charge balance calculation, is shown in the last row of the table and serves as a quality check of the chemical results. Values from 0.90 to 1.05 are generally considered acceptable. 
Table 4-1. Results of Analyses of Tank 241-AW-106 Boildown Sample Liquids. (2 sheets)

(All analysis results in units of $\mu \mathrm{g} / \mathrm{mL}$ )

\begin{tabular}{|c|c|c|c|c|c|c|c|c|c|c|c|}
\hline \multirow{2}{*}{$\begin{array}{r}\text { Test Sample } \\
\% \mathrm{WVR}^{18^{\circ} \mathrm{C}}\end{array}$} & $\mathrm{CP}$ & CON-1 & CON-2 & CON-3 & CON-4 & CON-5 & CON-6 & CON-7 & DIL-1 & DIL-2 & DIL-3 \\
\hline & 0.00 & 15.49 & 23.28 & 28.99 & 34.67 & 39.35 & 44.09 & 48.71 & 34.42 & 24.07 & 9.98 \\
\hline Total C & 7,780 & - & - & - & - & - & 12,600 & - & - & - & 8,910 \\
\hline TOC & $\begin{array}{l}1,340 \\
\end{array}$ & $\begin{array}{l}1,600 \\
\end{array}$ & $\begin{array}{l}1,870 \\
\end{array}$ & $\begin{array}{l}1,930 \\
\end{array}$ & 2,260 & $\begin{array}{l}1,970 \\
\end{array}$ & 2,060 & 2,500 & $\begin{array}{l}1,900 \\
\end{array}$ & $1,1,580$ & $\begin{array}{l}1,440 \\
\end{array}$ \\
\hline TIC & 6,330 & 7,600 & 8,640 & 9,330 & 10,600 & 11,100 & 8,980 & 7,720 & 10,200 & 8,760 & 7,330 \\
\hline as $\mathrm{CO}_{3}{ }^{\mathrm{b}}$ & 31,600 & 38,000 & 43,200 & 46,600 & 53,000 & 55,500 & 44,900 & 38,600 & 51,000 & 43,800 & 36,600 \\
\hline Acetate & 537 & 747 & 894 & 912 & 1,160 & 1,020 & 1,260 & 1,450 & 815 & 922 & 676 \\
\hline Glycolate & $<141$ & 743 & 831 & 821 & 725 & 790 & 848 & 997 & $<141$ & 665 & $<141$ \\
\hline Oxalate & 433 & 703 & 692 & 688 & 972 & $<346$ & $<346$ & $<346$ & $<346$ & $<346$ & $<346$ \\
\hline Nitrite & 38,300 & 52,600 & 61,600 & 63,300 & 69,800 & 74,000 & 85,400 & 103,000 & 68,200 & 52,800 & 50,100 \\
\hline Nitrate & 137,000 & 188,000 & 220,000 & 226,000 & 247,000 & 260,000 & 269,000 & 278,000 & 241,000 & 187,000 & 178,000 \\
\hline Chloride & 1,690 & 2,430 & 2,960 & 3,020 & 3,320 & 3,430 & 3,910 & 4,730 & 3,170 & 2,410 & 2,420 \\
\hline Bromide & $<870$ & $<870$ & $<870$ & $<870$ & $<870$ & $<870$ & $<870$ & $<870$ & $<870$ & $<870$ & $<870$ \\
\hline
\end{tabular}


Table 4-1. Results of Analyses of Tank 241-AW-106 Boildown Sample Liquids. (2 sheets)

(All analysis results in units of $\mu \mathrm{g} / \mathrm{mL}$ )

\begin{tabular}{|c|c|c|c|c|c|c|c|c|c|c|c|}
\hline \multirow{2}{*}{$\begin{array}{l}\text { Test Sample } \\
\% \mathrm{WVR}^{18^{\circ} \mathrm{C}}\end{array}$} & $\mathrm{CP}$ & CON-1 & CON-2 & CON-3 & $\mathrm{CON}-4$ & CON-5 & CON-6 & $\mathrm{CON}-7$ & DIL-1 & DIL-2 & DIL-3 \\
\hline & 0.00 & 15.49 & 23.28 & 28.99 & 34.67 & 39.35 & 44.09 & 48.71 & 34.42 & 24.07 & 9.98 \\
\hline $\mathrm{Na}$ & 127,000 & 149,000 & 165,000 & 177,000 & 188,000 & 199,000 & 210,000 & 205,000 & 186,000 & 166,000 & 145,000 \\
\hline $\mathrm{Al}$ & 5,870 & 7,030 & 7,850 & 8,480 & 9,050 & 9,820 & 11,700 & 12,600 & 9,180 & 8,030 & 6,890 \\
\hline $\mathrm{Si}$ & 51 & 167 & 96 & 77 & 84 & 83 & 105 & 111 & 83 & 70 & 61 \\
\hline \multirow{2}{*}{$\mathrm{P} \quad\left(\text { as } \mathrm{PO}_{4}\right)^{\mathrm{c}}$} & 690 & 403 & 391 & 332 & 302 & 297 & 315 & 328 & 344 & 372 & 461 \\
\hline & 2,120 & 1,240 & 1,200 & 1,020 & 926 & 911 & 966 & 1,010 & 1,060 & 1,140 & 1,410 \\
\hline \multirow{2}{*}{$\begin{array}{ll}\mathrm{S} & \left(\mathrm{as} \mathrm{SO}_{4}\right)^{\mathrm{c}} \\
\end{array}$} & 2,160 & 2,520 & 2,810 & 3,010 & 3,080 & 1,190 & 1,080 & 981 & 1,360 & 1,950 & 2,520 \\
\hline & 6,470 & 7,550 & 8,420 & 9,020 & 9,230 & 3,570 & 3,240 & 2,940 & 4,080 & 5,840 & 7,550 \\
\hline $\mathrm{K}$ & 4,420 & 5,200 & 5,760 & 6,210 & 6,630 & 7,180 & 8,310 & 9,230 & 6,720 & 5,890 & 5,070 \\
\hline $\mathrm{Ca}$ & $<160$ & $<160$ & $<160$ & $<160$ & $<160$ & $<160$ & $<160$ & $<160$ & $<160$ & $<160$ & $<160$ \\
\hline $\mathrm{Cr}$ & 484 & 594 & 656 & 707 & 753 & 816 & 904 & 1,050 & 771 & 676 & 581 \\
\hline $\mathrm{Fe}$ & 48 & 49 & 58 & 63 & 65 & 73 & 79 & 96 & 68 & 60 & 53 \\
\hline $\mathrm{Cd}$ & 3 & 3 & 3 & 4 & 4 & 4 & 5 & 6 & 4 & 3 & 3 \\
\hline $\mathrm{Ni}$ & 21 & 24 & 27 & 28 & 30 & 32 & 35 & 41 & 31 & 28 & 24 \\
\hline ChgBal (+/-) & 1.04 & 0.94 & 0.91 & 0.93 & 0.90 & 0.92 & 0.94 & 0.86 & 0.90 & 1.01 & 0.95 \\
\hline
\end{tabular}

${ }^{\mathrm{a}} \Delta \mathrm{TOC} \mu \mathrm{g} / \mathrm{mL}=\mu \mathrm{g} / \mathrm{mL}$ TOC $-[(\mu \mathrm{g} / \mathrm{mL}$ Formate $\times 0.2668)+(\mu \mathrm{g} / \mathrm{mL}$ Acetate $\times 0.4068)+(\mu \mathrm{g} / \mathrm{mL}$ Glycolate $\times 0.3201)+(\mu \mathrm{g} / \mathrm{mL}$ Oxalate $\times 0.2729)]$.

${ }^{\mathrm{b}} \mu \mathrm{g} / \mathrm{mL} \mathrm{CO} \mathrm{CO}_{3}=\mu \mathrm{g} / \mathrm{mL}$ TIC $\times 4.9961$.

${ }^{\mathrm{c}} \mathrm{P}$ and $\mathrm{S}$ were analyzed by ICP-AES. Analysis results were converted to phosphate and sulfate as follows: $\mathrm{PO}_{4} \mu \mathrm{g} / \mathrm{mL}=\mu \mathrm{g} / \mathrm{mL} \mathrm{P} \times 3.0662$ and

$\mathrm{SO}_{4} \mu \mathrm{g} / \mathrm{mL}=\mu \mathrm{g} / \mathrm{mL} \mathrm{S} \times 2.9959$ 


\section{DATA ANALYSIS}

\subsection{DENSITY}

In this report, bulk density, $\mathrm{D}_{\mathrm{Bulk}}$, is the density of a total sample, i.e., the density of the combined liquid and solid fractions of a sample. Liquid densities, $\mathrm{D}_{\text {Liq }}$ are the measured densities of the C-Liq portion of the samples processed in $15-\mathrm{mL}$ centrifuge cones. The density of the initial composite is reported as a $\mathrm{D}_{\text {Bulk }}$ when measured in triplicate in $100-\mathrm{mL}$ volumetric flasks and as a $\mathrm{D}_{\mathrm{Liq}}$ when measured on the subsample in the $15-\mathrm{mL}$ cone.

\subsubsection{Bulk Density of Tank 241-AW-106 Boildown Samples}

The $\mathrm{D}_{\text {Bulk }} 27.1^{\circ} \mathrm{C}$ for the initial composite is believed to be the most accurately measured density in this study since it was obtained using $100-\mathrm{mL}$ volumetric flasks. The $\mathrm{D}_{\mathrm{Bulk}}{ }^{{ }^{\circ} \mathrm{C}}$ values, tabulated in Table 3-3, are based on volume measurements of the boildown samples, at $18.0^{\circ} \mathrm{C}$, in the $15-\mathrm{mL}$ centrifuge cones in which they were collected. These volume (and $\mathrm{D}_{\mathrm{Bulk}}{ }^{1{ }^{\circ} \mathrm{C}}$ ) measurements were made as carefully as possible but are less accurate than those for the initial composite.

In Table B-2 (Attachment B), the additive volumes model calculations are reset to a base temperature of $18.0^{\circ} \mathrm{C}$. This temperature was chosen to represent common temperatures of the waste tanks. The volume of the initial composite sample was corrected to account for cooling. Previous measurements (Mem-052174, "Densities of Caustic Waste Solutions as a Function of Temperature") showed that the thermal expansion coefficients of two synthetic tank waste concentrates were $4.409 \times 10^{-4}$ and $4.838 \times 10^{-4}(\Delta \mathrm{mL} / \mathrm{mL}) / \Delta^{\circ} \mathrm{C}$ over a range of $22-56.5^{\circ} \mathrm{C}$. Another set of measurements (WRPS-0900372, "Results of Lifetime Testing of Anton Paar DMA 35N Portable Density Meter") showed that thermal expansion coefficients of a double-shell tank waste simulant were $3.757 \times 10^{-4}(\Delta \mathrm{mL} / \mathrm{mL}) / \Delta^{\circ} \mathrm{C}$ from $18-30{ }^{\circ} \mathrm{C}$ and $6.843 \times 10^{-4}(\Delta \mathrm{mL} / \mathrm{mL}) / \Delta^{\circ} \mathrm{C}$ from $30-42{ }^{\circ} \mathrm{C}$. An average value of $4.335 \times 10^{-4}(\Delta \mathrm{mL} / \mathrm{mL}) / \Delta^{\circ} \mathrm{C}$ was used to adjust the initial composite volume. The corresponding $\mathrm{D}_{\mathrm{Bulk}}{ }^{1{ }^{\circ} \mathrm{C}}$ was $1.271 \mathrm{~g} / \mathrm{mL}$.

The calculated $\mathrm{D}_{\text {Model }} 18^{\circ} \mathrm{C}$ and measured $\mathrm{D}_{\text {Bulk }}{ }^{\circ{ }^{\circ} \mathrm{C}}$ values are plotted against $C R_{\text {Model }}{ }^{\circ} \mathrm{C}$ in Figure 5-1. The $\mathrm{D}_{\mathrm{Liq}}{ }^{1{ }^{\circ} \mathrm{C}}$ values have also been plotted for comparison. In this figure and all other plots in this report, values for the initial test composite (CP) and the volume reduction sequence samples (CON-1 to CON-7) are displayed with solid data markers; values for the dilution sequence samples (DIL-1 to DIL-3) are displayed with hollow data markers of the same shape and border color.

The plot of measured $\mathrm{D}_{\text {Bulk }}{ }^{\circ} \mathrm{C}$ vs. $C R_{\text {Model }}{ }^{1{ }^{\circ} \mathrm{C}}$ in Figure 5-1 clearly deviates from the linear projection of the additive volumes model. The concentrate volumes indicated by the $\mathrm{D}_{\mathrm{Bulk}} 18^{\circ} \mathrm{C}$ values are larger than those predicted by the additive volumes model. Small downward curvature in plots of density vs. $C R$ is common for concentrated solutions of chemical species found in tank wastes. It is also quite likely that as the quantity of solid precipitates in the concentrates increases, the additive volumes assumption of the model becomes an increasingly 
poor one. The pronounced decrease in the slope of the $\mathrm{D}_{\mathrm{Liq}}{ }^{1{ }^{\circ} \mathrm{C}}$ plot beginning at CR 1.7 (Sample CON-5) suggests that this is a factor.

Figure 5-1. Comparison of Model and Measured Bulk Densities.

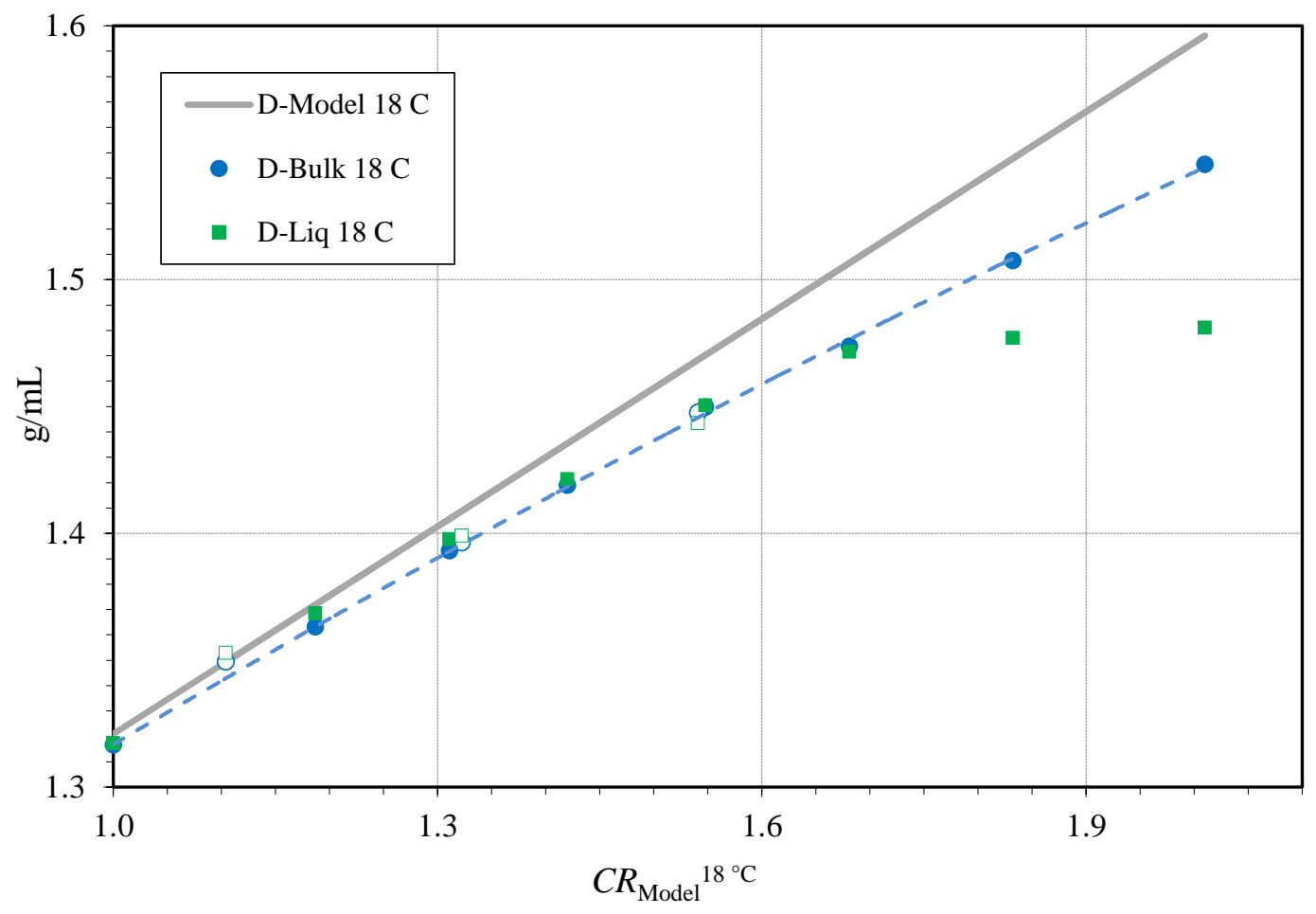

\subsubsection{Test Values of $C R$ and \%WVR}

The measured $\mathrm{D}_{\mathrm{Bulk}} 1{ }^{\circ} \mathrm{C}$ values can be used to calculate the virtual volumes of $18.0{ }^{\circ} \mathrm{C}$ pot concentrates at each step of the boildown test. These volumes can then be used to calculate values of $C R$ and $\% \mathrm{WVR}$ actually reached, $C R^{18{ }^{\circ} \mathrm{C}}$ and $\% \mathrm{WVR}{ }^{18^{\circ} \mathrm{C}}$. These calculations are shown in Table 5-1. The calculation chain proceeds down a column of the table for each boildown step.

1. The weight and volume of concentrate at the beginning of the step are entered. These values are the weight and volume of concentrate at the end of the previous step.

2. The weight of the concentrate is then adjusted by the weight of water removed/added.

3. The new concentrate weight is converted to a new volume by dividing by $\mathrm{D}_{\mathrm{Bulk}}{ }^{1{ }^{\circ} \mathrm{C}}$.

4. The $C R^{18{ }^{\circ} \mathrm{C}}$ is then calculated using Equations 3-1 and 3-5.

5. The $\% \mathrm{WVR}^{18^{\circ} \mathrm{C}}$ is then calculated using Equation 3-6.

6. The final concentrate weight is then calculated by subtracting the weight of sample removed.

7. The final step concentrate weight is converted to a final step volume by dividing by $\mathrm{D}_{\text {Bulk }}{ }^{10^{\circ} \mathrm{C}}$. 
Table 5-1. Calculation of Test Values of $C R$ and \%WVR.

\begin{tabular}{|c|c|c|c|c|c|c|c|c|}
\hline & $\mathbf{C P}$ & CON 1 & CON 2 & CON 3 & CON 4 & CON 5 & CON 6 & CON 7 \\
\hline Wt Co & 618.2 & 618.2 & 525.2 & 470.8 & 427.0 & 384.1 & 344.8 & 306.9 \\
\hline Vol C & 488.1 & 488.1 & 400.0 & 350.5 & 311.9 & 274.4 & 242.2 & 210.6 \\
\hline$\Delta \mathrm{H}_{2} \mathrm{O}(\mathrm{g})$ & 0.000 & 76.519 & 37.562 & 26.617 & 25.357 & 21.359 & 19.436 & 18.014 \\
\hline Wt Concentrate (g) & 618.2 & 541.7 & 487.7 & 444.2 & 401.6 & 362.7 & 325.4 & 288.9 \\
\hline $\mathrm{D}_{\text {Bulk }}{ }^{1{ }^{\circ} \mathrm{C}}(\mathrm{g} / \mathrm{mL})$ & 1.267 & 1.313 & 1.343 & 1.369 & 1.400 & 1.424 & 1.458 & 1.495 \\
\hline Vol Concentrate $(\mathrm{mL})$ & 488.1 & 412.5 & 363.1 & 324.5 & 286.9 & 254.8 & 223.2 & 193.2 \\
\hline$C R^{18^{\circ} \mathrm{C}}$ & 1.000 & 1.183 & 1.304 & 1.408 & 1.531 & 1.649 & 1.789 & 1.950 \\
\hline$\% \mathrm{WVR}^{18^{\circ} \mathrm{C}}$ & 0.00 & 15.49 & 23.28 & 28.99 & 34.67 & 39.35 & 44.09 & 48.71 \\
\hline Wt Sample Rmvd (g) & 0.000 & 16.466 & 16.856 & 17.207 & 17.552 & 17.882 & 18.466 & 19.006 \\
\hline Wt Concentrate $(\mathrm{g})$ & 618.2 & 525.2 & 470.8 & 427.0 & 384.1 & 344.8 & 306.9 & 269.9 \\
\hline Vol Concentrate $(\mathrm{mL})$ & 488.1 & 400.0 & 350.5 & 311.9 & 274.4 & 242.2 & 210.6 & 180.5 \\
\hline
\end{tabular}

\begin{tabular}{|l|r|r|r|}
\hline & \multicolumn{1}{|c|}{ DIL 1 } & \multicolumn{1}{c|}{ DIL 2 } & \multicolumn{1}{c|}{ DIL 3 } \\
\hline Wt Concentrate $(\mathrm{g})$ & 269.9 & 305.1 & 323.4 \\
\hline Vol Concentrate $(\mathrm{mL})$ & 180.5 & 218.3 & 240.2 \\
\hline$\Delta \mathrm{H}_{2} \mathrm{O}(\mathrm{g})$ & -52.618 & -35.223 & -46.595 \\
\hline Wt Concentrate $(\mathrm{g})^{\circ}$ & 322.5 & 340.4 & 367.0 \\
\hline $\mathrm{D}_{\text {Bulk }}{ }^{1{ }^{\circ} \mathrm{C}}(\mathrm{g} / \mathrm{mL})$ & 1.398 & 1.346 & 1.299 \\
\hline Vol Concentrate $(\mathrm{mL})^{2}$ & 230.8 & 252.8 & 284.7 \\
\hline $\boldsymbol{C R}^{\mathbf{1 8}}{ }^{\circ} \mathbf{C}$ & 1.525 & 1.317 & 1.111 \\
\hline \% WVR $^{\mathbf{1 8}}{ }^{\mathbf{C}}$ & 34.42 & 24.07 & 9.98 \\
\hline Wt Sample Rmvd $(\mathrm{g})$ & 17.386 & 16.951 & 16.308 \\
\hline Wt Concentrate $(\mathrm{g})$ & 305.1 & 323.4 & 353.7 \\
\hline Vol Concentrate $(\mathrm{mL})$ & 218.3 & 240.2 & 272.2 \\
\hline
\end{tabular}

The values of $C R^{18^{\circ} \mathrm{C}}$ and $\% \mathrm{WVR}^{18^{\circ} \mathrm{C}}$ calculated in Table 5-1 are the boildown progress parameters used throughout the remainder of this report. The $\mathrm{D}_{\mathrm{Bulk}}{ }^{1{ }^{\circ} \mathrm{C}}$ values are plotted against $C R_{\text {Model }}{ }^{{ }^{\circ} \mathrm{C}}$ and $C R^{18^{\circ} \mathrm{C}}$ in Figure 5-2 for comparison. 
Figure 5-2. Bulk Densities at $18{ }^{\circ} \mathrm{C}$ versus Concentration Ratio.

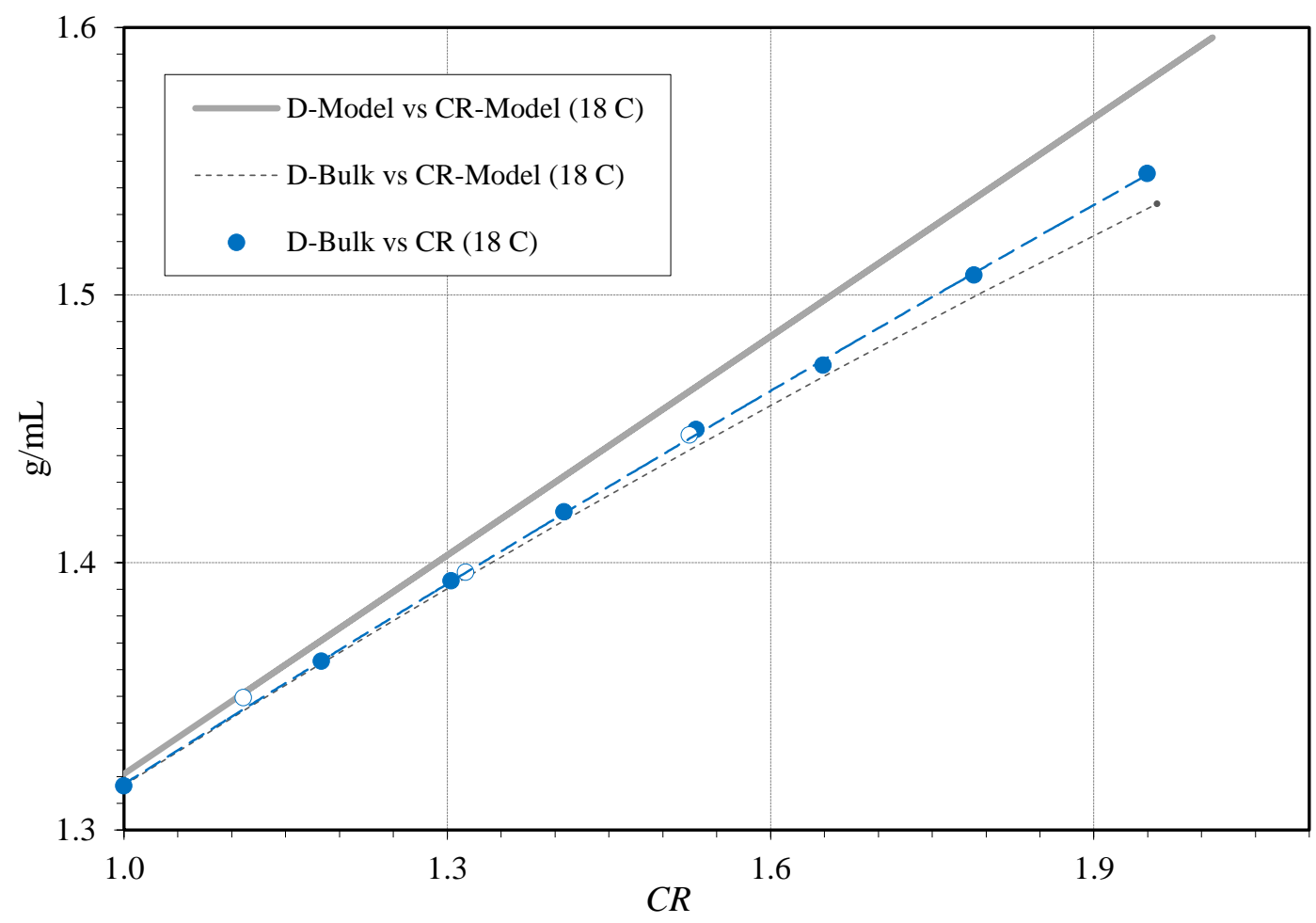

\subsubsection{Volumes and Densities at Process Temperatures}

Estimates of $\mathrm{D}_{\mathrm{Bulk}}$ of the concentrated composite at boildown process temperatures (boiling temperatures) are of interest as an indicator of real-time densities that may be observed during a 242-A Evaporator campaign. To estimate these in-process $D_{\text {Bulk }}$ values, the volumes of the boildown samples at $18.0{ }^{\circ} \mathrm{C}$ were adjusted to estimated volumes at the boiling temperatures of the pot concentrates at 60 Torr.

The temperature adjustment process is shown in Table 5-2. The total and C-Slds volumes at $18.0^{\circ} \mathrm{C}$ are the base measurements. The fraction of the measured $\mathrm{C}$-Slds volumes that are true solids must be assumed and is assigned a value of 0.5 in the table. The volumes of the solid and liquid portions of the samples at $18.0{ }^{\circ} \mathrm{C}$ are then calculated. A thermal expansion coefficient of $4.335 \times 10^{-4}(\Delta \mathrm{mL} / \mathrm{mL}) / \Delta^{\circ} \mathrm{C}$ was used to adjust the volumes of the liquids from $18-30{ }^{\circ} \mathrm{C}$. A coefficient of $5.364 \times 10^{-4}(\Delta \mathrm{mL} / \mathrm{mL}) / \Delta^{\circ} \mathrm{C}$ was then used to adjust these volumes from $30^{\circ} \mathrm{C}$ to the measured boiling temperatures at 60 Torr. The sources of the above thermal expansion factors were noted in Section 5.1.1.

The adjusted total sample volumes were then calculated by adding the volumes of the $18.0^{\circ} \mathrm{C}$ solids and the adjusted liquid volumes. Temperature reported adjusted densities, $\mathrm{D}_{\mathrm{Bulk}} 60$ Torr were then obtained by dividing the sample weights by the adjusted total volumes. 
Table 5-2. Adjusted Sample Volumes and Densities at Process Temperatures.

[Adjusted densities of samples at boiling temperatures at 60 Torr $\left(\mathrm{T}_{3}\right)$ in bottom-right column.]

\begin{tabular}{|c|c|c|c|c|c|c|}
\hline & & & & \multirow{2}{*}{\multicolumn{2}{|c|}{$\frac{\text { Vol }_{\text {Solids }} / \text { Vol }_{\text {C-Slds }}}{0.500}$}} & \multirow{3}{*}{$\begin{array}{l} \\
\text { Vol }_{\text {Liquid }} \\
\text { at } \mathbf{T}_{1} \\
(\mathrm{~mL}) \\
\end{array}$} \\
\hline & & & & & & \\
\hline Sample & $\begin{array}{c}\mathbf{W t}_{\text {Total }} \\
(\mathrm{g}) \\
\end{array}$ & $\begin{array}{c}\mathbf{T}_{1} \\
\left({ }^{\circ} \mathbf{C}\right) \\
\end{array}$ & $\begin{array}{l}\mathbf{V o l}_{\text {Total }} \\
\text { at } \mathbf{T}_{1} \\
(\mathrm{~mL}) \\
\end{array}$ & $\begin{array}{c}\text { Vol }_{\text {C-Slds }} \\
\text { at } \mathbf{T}_{1} \\
(\mathbf{m L}) \\
\end{array}$ & $\begin{array}{c}\text { Vol }_{\text {Solids }} \\
\text { at } \mathbf{T}_{1} \\
(\mathbf{m L}) \\
\end{array}$ & \\
\hline $\mathrm{CP}$ & 16.275 & 18.0 & 12.85 & 0.00 & 0.000 & 12.85 \\
\hline CON-1 & 16.466 & 18.0 & 12.54 & 0.07 & 0.035 & 12.51 \\
\hline $\mathrm{CON}-2$ & 16.856 & 18.0 & 12.55 & 0.10 & 0.050 & 12.50 \\
\hline CON-3 & 17.207 & 18.0 & 12.57 & 0.15 & 0.075 & 12.50 \\
\hline CON-4 & 17.552 & 18.0 & 12.54 & 0.19 & 0.095 & 12.45 \\
\hline CON-5 & 17.882 & 18.0 & 12.56 & 0.40 & 0.200 & 12.36 \\
\hline CON-6 & 18.466 & 18.0 & 12.67 & 3.20 & 1.600 & 11.07 \\
\hline CON-7 & 19.006 & 18.0 & 12.71 & 4.00 & 2.000 & 10.71 \\
\hline DIL-1 & 17.386 & 18.0 & 12.44 & 0.55 & 0.275 & 12.17 \\
\hline DIL-2 & 16.951 & 18.0 & 12.59 & 0.32 & 0.160 & 12.43 \\
\hline DIL-3 & 16.308 & 18.0 & 12.55 & 0.10 & 0.050 & 12.50 \\
\hline
\end{tabular}

\begin{tabular}{|c|c|c|c|c|c|c|}
\hline \multirow[b]{3}{*}{ Sample } & \multicolumn{4}{|c|}{$(\Delta \mathrm{mL} / \mathrm{mL}) / \Delta^{\circ} \mathrm{C}$} & \multirow[b]{3}{*}{$\begin{array}{l}\text { Vol }_{\text {Total }} \\
\text { at } \mathbf{T}_{\mathbf{3}} \\
(\mathbf{m L}) \\
\end{array}$} & \multirow[b]{3}{*}{$\begin{array}{c}\mathrm{D}_{\text {Bulk }} \\
\text { at } \mathrm{T}_{3} \\
(\mathrm{~g} / \mathrm{mL})\end{array}$} \\
\hline & \multicolumn{2}{|c|}{0.00043349} & \multicolumn{2}{|c|}{0.00053635} & & \\
\hline & $\begin{array}{c}\mathbf{T}_{2} \\
\left({ }^{\circ} \mathbf{C}\right) \\
\end{array}$ & $\begin{array}{c}\text { Vol }_{\text {Liquid }} \\
\text { at } \mathbf{T}_{2} \\
(\mathbf{m L}) \\
\end{array}$ & $\begin{array}{c}\mathbf{T}_{3} \\
\left({ }^{\circ} \mathbf{C}\right) \\
\end{array}$ & $\begin{array}{c}\text { Vol }_{\text {Liquid }} \\
\text { at } \mathbf{T}_{3} \\
(\mathbf{m L})\end{array}$ & & \\
\hline $\mathrm{CP}$ & 30.0 & 12.92 & 46.04 & 13.03 & 13.03 & 1.249 \\
\hline $\mathrm{CON}-1$ & 30.0 & 12.57 & 47.32 & 12.69 & 12.72 & 1.294 \\
\hline $\mathrm{CON}-2$ & 30.0 & 12.57 & 47.82 & 12.69 & 12.74 & 1.324 \\
\hline $\mathrm{CON}-3$ & 30.0 & 12.56 & 48.95 & 12.69 & 12.76 & 1.348 \\
\hline $\mathrm{CON}-4$ & 30.0 & 12.51 & 49.59 & 12.64 & 12.74 & 1.378 \\
\hline $\mathrm{CON}-5$ & 30.0 & 12.42 & 50.78 & 12.56 & 12.76 & 1.401 \\
\hline $\mathrm{CON}-6$ & 30.0 & 11.13 & 51.66 & 11.26 & 12.86 & 1.436 \\
\hline $\mathrm{CON}-7$ & 30.0 & 10.77 & 51.66 & 10.89 & 12.89 & 1.474 \\
\hline DIL-1 & 30.0 & 12.23 & 49.50 & 12.36 & 12.63 & 1.376 \\
\hline DIL-2 & 30.0 & 12.49 & 48.11 & 12.62 & 12.78 & 1.327 \\
\hline DIL-3 & 30.0 & 12.57 & 46.83 & 12.68 & 12.73 & 1.281 \\
\hline
\end{tabular}

In the above calculations, the $18.0{ }^{\circ} \mathrm{C} \mathrm{C}$-Slds are assumed to contain a constant $50 \%$ interstitial liquid, and the volumes of solids present at $18.0^{\circ} \mathrm{C}$ and at process temperatures are assumed to be equal. Both these assumptions are only approximations. The impact of the assumed solids content of the samples at elevated temperature on the adjusted volumes increases as the solids volume increases and is not large until large volumes of solids are present. 
The measured $\mathrm{D}_{\mathrm{Bulk}}{ }^{10^{\circ} \mathrm{C}}$ and estimated $\mathrm{D}_{\mathrm{Bulk}}{ }^{60}$ Torr values are plotted against $\% \mathrm{WVR}{ }^{18}{ }^{\circ} \mathrm{C}$ in Figure 5-3. The estimated $\mathrm{D}_{\mathrm{Bulk}}{ }^{60}$ Torr values are based on assumptions (true solids content at process temperatures) and indirect supporting data (liquid thermal expansion coefficients). The temperature-adjusted values do indicate, however, that real-time measurements of the densities of boildown composite will return values that are smaller than those based on measurements at lower temperatures. For example, for Sample CON-5, collected during the initial onset of solids, the estimated $\mathrm{D}_{\mathrm{Bulk}}{ }^{60 \text { Torr }}$ is $0.022 \mathrm{~g} / \mathrm{mL}$ smaller than the measured $\mathrm{D}_{\mathrm{Bulk}}{ }^{\circ{ }^{\circ} \mathrm{C}}$ value.

Figure 5-3. Bulk Densities at Process Temperatures versus $\% \mathrm{WVR}^{18^{\circ} \mathrm{C}}$.

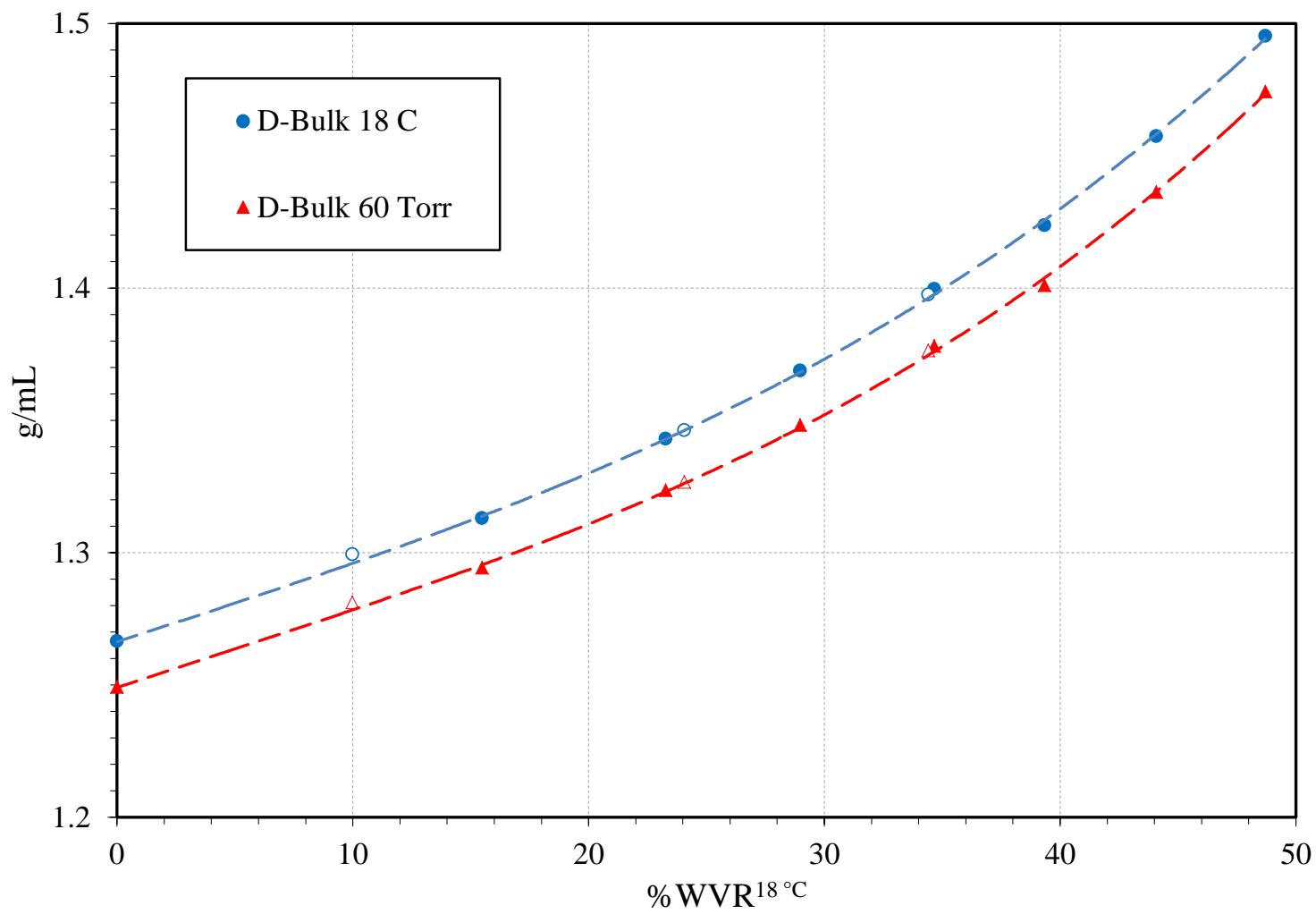

Fit Lines: $\mathrm{D}_{\text {Bulk }}{ }^{1{ }^{\circ} \mathrm{C}}=\left(7.85 \times 10^{-7}\right)(\% \mathrm{WVR})^{3}-\left(1.84 \times 10^{-6}\right)(\% \mathrm{WVR})^{2}+\left(2.91 \times 10^{-3}\right)(\% \mathrm{WVR})+1.27$

$\mathrm{D}_{\text {Bulk }}{ }^{60 \text { Torr }}=\left(9.76 \times 10^{-7}\right)(\% \mathrm{WVR})^{3}-\left(1.42 \times 10^{-5}\right)(\% \mathrm{WVR})^{2}+\left(2.99 \times 10^{-3}\right)(\% \mathrm{WVR})+1.25$

\subsection{BOILDOWN TEMPERATURE CURVES}

The boiling temperatures $\left(\mathrm{T}_{\mathrm{Corr}}\right)$ of the $\mathrm{AW}-106$ composite at the three nominal test pressures of 40, 60, and 80 Torr are plotted against boildown progress in Figure 5-4. The boiling temperatures are taken from Table B-2 in Attachment B. Boiling temperatures are plotted against \%WVR ${ }^{18^{\circ} \mathrm{C}}$ in Figure 5-4(a) and against estimated $\mathrm{D}_{\mathrm{Bulk}}{ }^{60}$ Torr in Figure 5-4(b).

The temperature curves shown in the figures were constrained to pass through the reference boiling temperatures and densities of pure water at the nominal test pressures. The resulting curves display steadily increasing boiling temperatures as the volume reduction progressed without any significant discontinuities. Within the estimated measurement precision, boiling 
temperatures measured during the dilution sequence at 60 Torr were those that would have been predicted based on the concentration sequence measurements.

Figure 5-4. Boiling Temperature versus Boildown Progress.
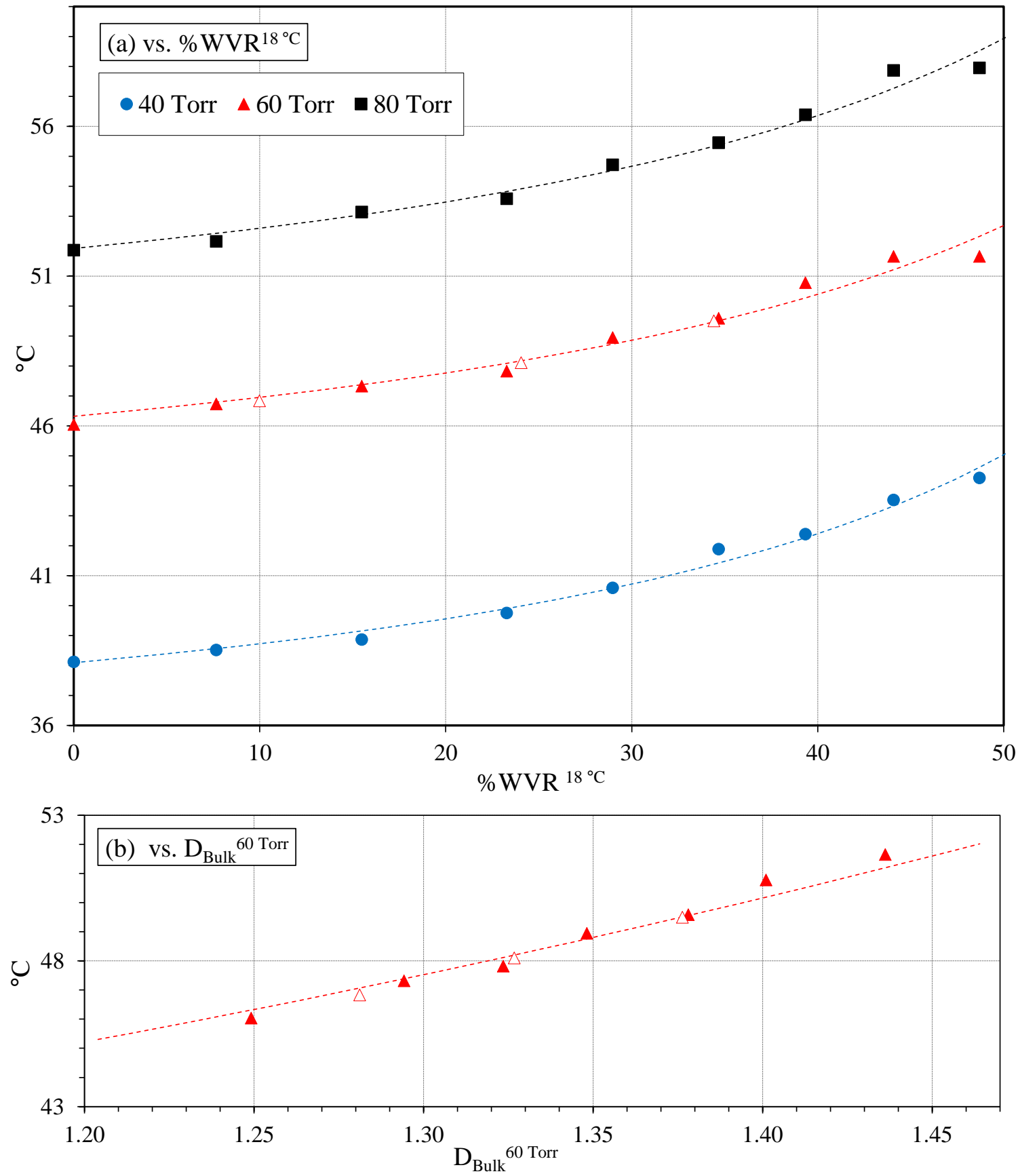


\subsection{QUANTITY OF SOLIDS IN COOL CONCENTRATES}

\subsubsection{Boildown Volume Reduction Samples}

The quantities of solids found in the original composite and the 7 samples that were withdrawn from the boildown pot during the volume reduction sequence ( $\mathrm{CP}$ through $\mathrm{CON}-7)$ and then cooled to $18.0^{\circ} \mathrm{C}$ for 5 days are graphically displayed in Figure 5-5. The quantity of solids data was tabulated in Table 3-3. Three quantities are displayed against $\mathrm{D}_{\text {Bulk }}{ }^{60}$ Torr in Figure 5-5(a): the vol\% S-Slds found after a maximum of $42 \mathrm{hrs}^{1}$ at hot cell ambient temperature $\left(\sim 24.4^{\circ} \mathrm{C}\right)$, the vol\% S-Slds found after the samples had been in the $18.0{ }^{\circ} \mathrm{C}$ water bath for 5 days, and the vol\% C-Slds found after the samples had been in the water bath and then centrifuged. Photographs of the S-Slds and C-Slds in the samples are presented in Attachment C.

Settled solids begin to be observed in Sample CON-5 and quickly increased in volume percent for CON-6 and CON-7. A small amount of solids were also present in the centrifuge cones for CON-1 through CON-4 but were attached to the cone wall. These solids appeared after sample collection and were measured only after centrifugation when they were forced to the bottom of the cone.

Figure 5-5(a) and the photographs in Attachment $\mathrm{C}$ indicate that most of the solids in the boildown samples were present after cooling to ambient hot cell temperatures as the volumes of additional solids that formed while the samples were in the $18.0^{\circ} \mathrm{C}$ water bath were smaller or roughly equal to the decreases in the volumes of the S-Slds due to compaction. Sample photographs and observations during the boildown also suggest that a significant portion of the solids found in the $18.0{ }^{\circ} \mathrm{C}$ concentrate samples were already present in the boildown pot at process temperatures. Even though some solids precipitated and adhered to the cone surface during cooling, these amounts were small as seen by the red bars for Samples CON-1 through CON-4.

Comparison of the vol\% S-Slds and vol\% C-Slds in the samples after cooling to $18.0^{\circ} \mathrm{C}$ for 5 days is informative. The samples settled to produce a clear supernatant liquid within a few hours after removal from the boildown pot. The vol\% C-Slds data suggests that the initial volume of S-Slds found in concentrated evaporator feeds might be expected to decrease by as much as $50 \%$ as the $\mathrm{S}$-Slds compact over time.

In Figure 5-5(b) the vol\% C-Slds and wt\% C-Slds data are compared. Both of these quantities can be difficult to measure accurately when small quantities of solids are present. Nevertheless, the two data sets display very similar trends in the increase of solids with boildown progress.

\footnotetext{
${ }^{1}$ Sample CON 1 sat at hot cell ambient temperature for $42 \mathrm{hrs}$. The remaining 6 samples sat at hot cell ambient temperature for 18-24 hrs.
} 
Figure 5-5. Quantity of Solids in Cooled Concentrates.
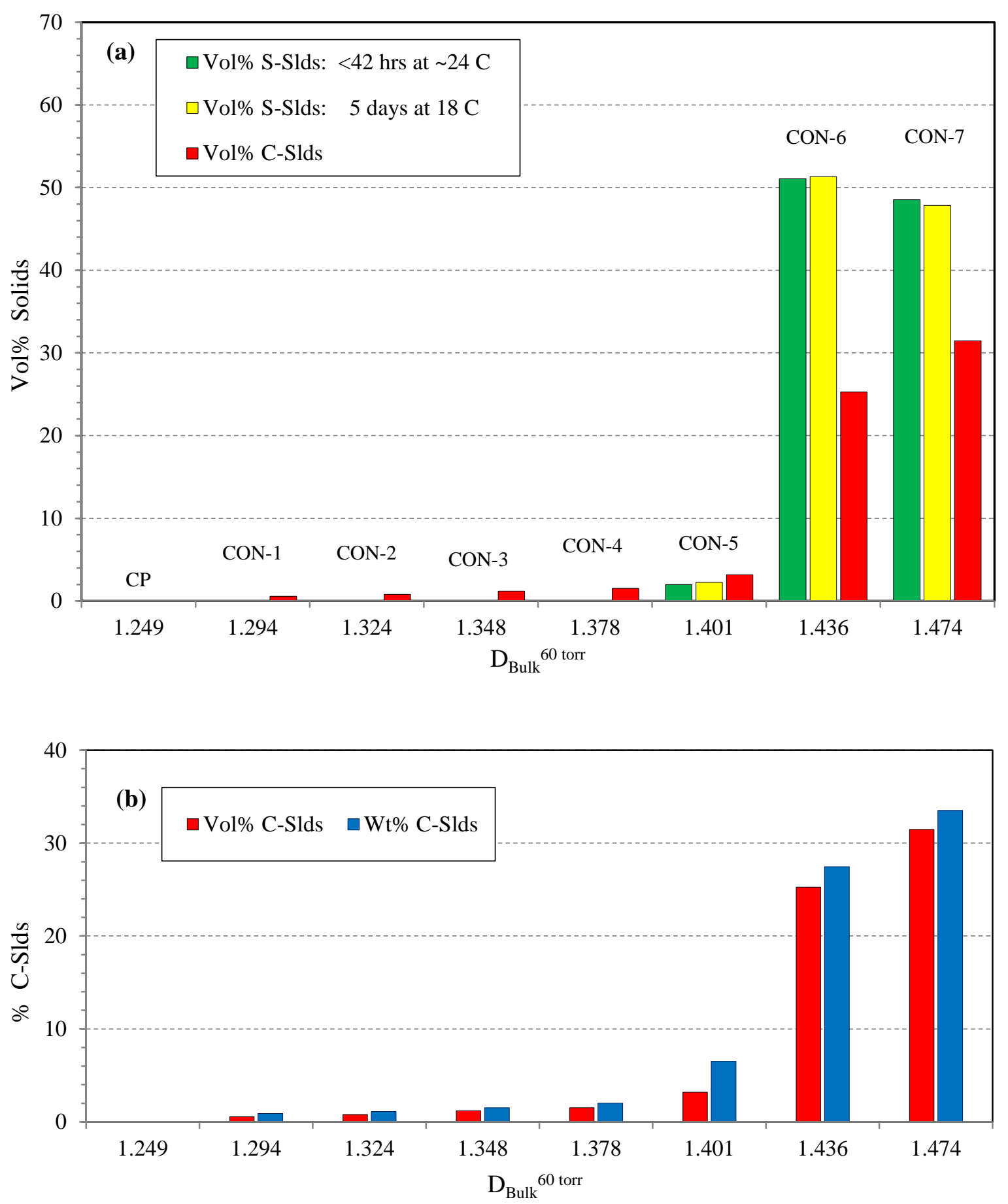
Part of the apparent increase in the amounts of solids present in the concentrates as the volume reduction progresses is due solely to the reduction in the volume of the test slurry. The predicted quantity of solids that would be found in a sample if solids formation ceased after the preceding boildown step is:

$$
\text { Predicted } \% \text { Slds }=(\% \text { Slds at the end of the previous step })\left(C R_{\text {Step }}\right)
$$

The predicted, based on Equation 5-1, and measured quantities of solids present in the boildown volume reduction samples are displayed in Figure 5-6 for the vol\% and wt\% C-Slds data $\left(18.0^{\circ} \mathrm{C}\right)$. This format emphasizes that the quantities of new solids in the CON-1through CON-4 concentrates were relatively small and relatively consistent. The solids begin to precipitate at CON-5 and quickly escalate by CON-6 and increase slightly at CON-7.

Figure 5-6. Quantities of New Solids in Concentrates.
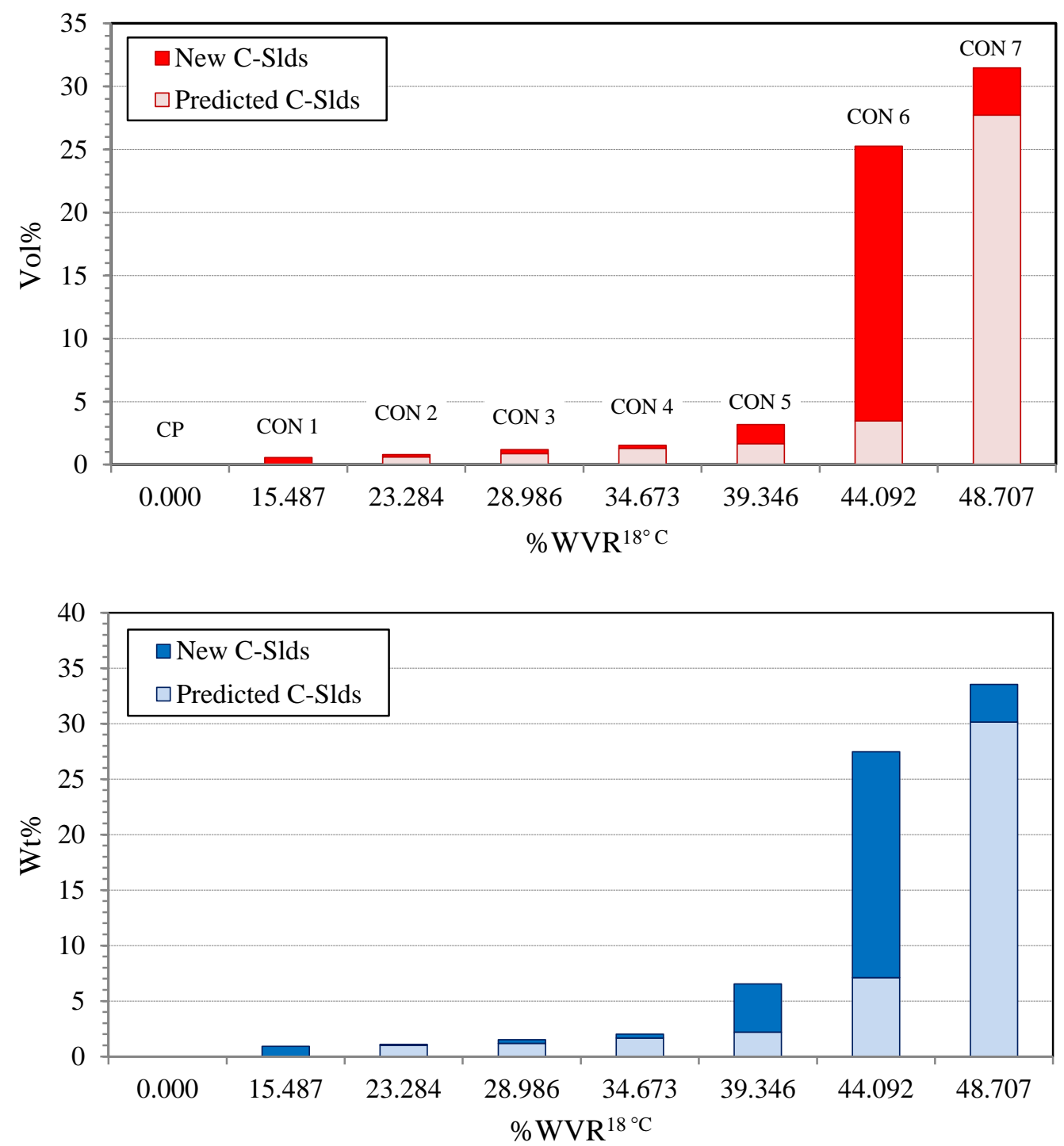


\subsubsection{End-point Slurry Dilution Samples}

The quantities of solids found in the three dilution sequence samples, DIL-1 through DIL-3, are displayed in Figure 5-7 along with the samples from the concentration steps for reference. Data for the vol\% C-Slds and wt\% C-Slds found in the samples after cooling in the $18.0{ }^{\circ} \mathrm{C}$ water bath are shown.

All the dilution samples contain relatively greater amounts of solids than the surrounding samples from the volume reduction. This suggests that some supersaturation of the composite could have been present before solids were initially observed in CON-5. Another cause of the increased solids amount in the dilution samples could be a low dissolution rate of the solids.

Figure 5-7. Quantity of Solids in Dilution Samples at $18{ }^{\circ} \mathrm{C}$.

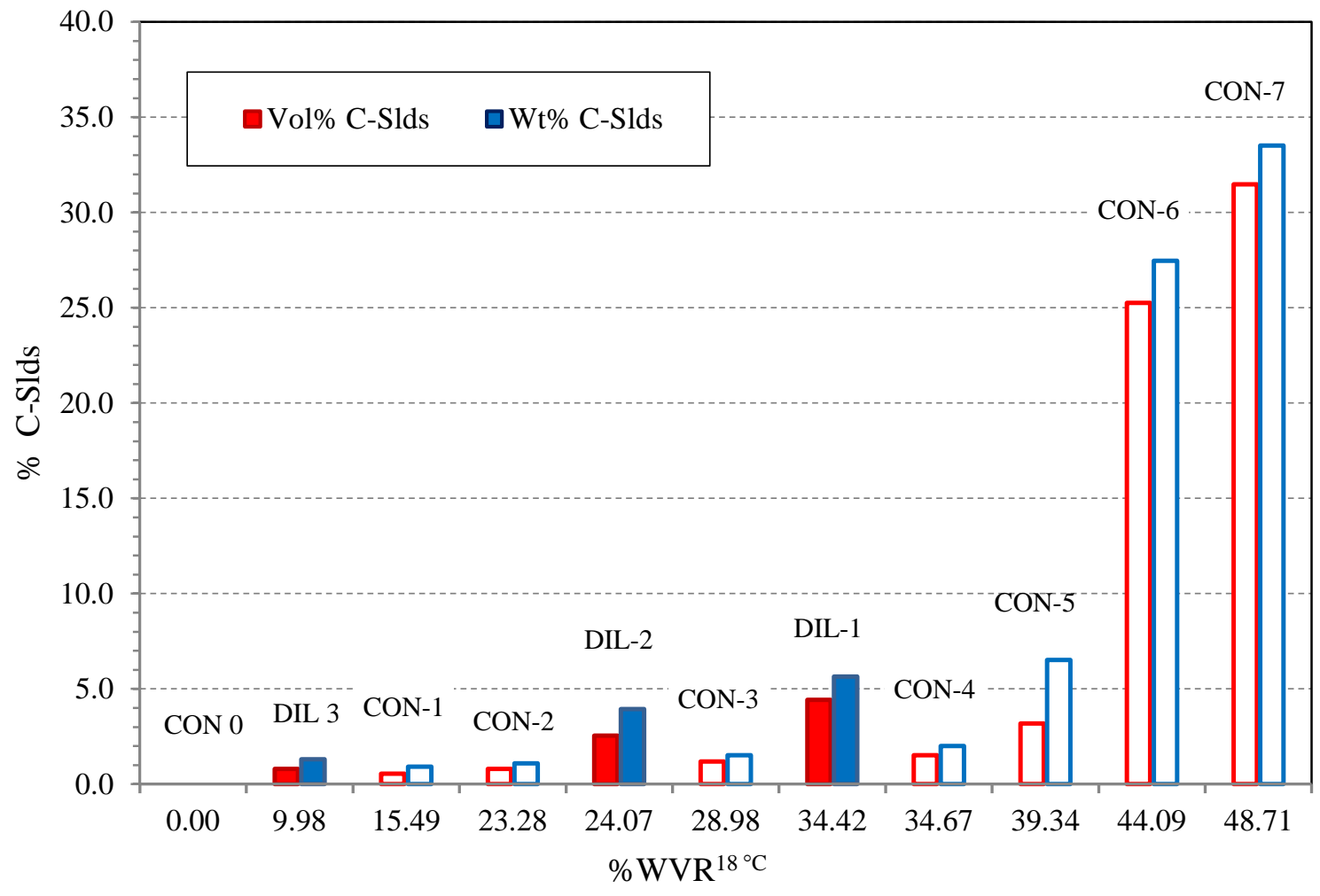

\subsubsection{Calculated Weights of Solids in Boildown Samples}

A check of the volume and density measurements/calculations performed in this study can be made by calculating the weights of dry solids predicted to be present after the concentrates from each volume reduction step cooled to $18.0^{\circ} \mathrm{C}$. After conversion to $\mathrm{wt} \%$ dry solids values, these calculated weights can be compared to the measured wt $\%$ wet C-Slds values.

The calculation series is shown in Table 5-3. Proceeding down a column for each boildown step, the following calculations are performed (rows where the calculations are performed are highlighted in green). 
1. The final volume of the concentrate at $18.0{ }^{\circ} \mathrm{C}\left(\mathrm{Vol}_{\text {Step }}{ }^{1{ }^{\circ} \mathrm{C}}\right)$ is calculated:

$$
\mathrm{Vol}_{\text {Initial }}{ }^{1{ }^{\circ} \mathrm{C}} / C R^{18^{\circ} \mathrm{C}}
$$

2. The final weight of the step concentrate, $\mathrm{Wt}_{\text {Step }}$, is calculated:

$$
\left(\text { Vol }_{\text {Step }} 18^{\circ} \mathrm{C}\right)\left(\mathrm{D}_{\text {Bulk }}{ }^{\circ}{ }^{\circ} \mathrm{C}\right)
$$

3. The estimated volume of liquid in the concentrate at $18.0{ }^{\circ} \mathrm{C}, \operatorname{Vol}_{\mathrm{Liq}}{ }^{1{ }^{\circ} \mathrm{C}}$, is calculated:

$$
\left(\text { Vol }_{\text {Step }}{ }^{1{ }^{\circ} \mathrm{C}}\right)\left(f_{\text {Liq }}\right)
$$

4. The weight of the liquid in the concentrate, Wt Liquid, is calculated:

$$
\left(\operatorname{Vol}_{\text {Liq }}{ }^{18^{\circ} \mathrm{C}}\right)\left(\mathrm{D}_{\mathrm{Liq}}{ }^{18^{\circ} \mathrm{C}}\right)
$$

5. The weight of dry solids in the concentrate, Wt Dry Solids, is calculated:

$$
\mathrm{Wt}_{\text {Step }}-\mathrm{Wt} \text { Liquid }
$$

\begin{tabular}{|c|c|c|c|c|c|c|c|c|c|}
\hline & Step & $\mathbf{C P}$ & CON 1 & CON 2 & CON 3 & CON 4 & CON 5 & CON 6 & CON 7 \\
\hline \multicolumn{2}{|c|}{$\% \mathrm{WVR}^{18{ }^{\circ} \mathrm{C}}$} & 0.00 & 15.49 & 23.28 & 29.00 & 34.67 & 39.35 & 44.10 & 48.71 \\
\hline $\mathrm{Vol}_{\text {Initial }} 18^{\circ} \mathrm{C}$ & $\mathrm{mL}$ & 488.1 & - & - & - & - & - & - & - \\
\hline$C R^{18^{\circ} \mathrm{C}}$ & & 1.000 & 1.183 & 1.304 & 1.408 & 1.531 & 1.649 & 1.789 & 1.950 \\
\hline $\mathrm{Vol}_{\text {Step }} 18^{\circ} \mathrm{C}$ & $\mathrm{mL}$ & 488.1 & 412.5 & 374.5 & 346.6 & 318.9 & 296.1 & 272.9 & 250.4 \\
\hline $\mathrm{D}_{\text {Bulk }}{ }^{18^{\circ} \mathrm{C}}$ & $\mathrm{g} / \mathrm{mL}$ & 1.267 & 1.313 & 1.343 & 1.369 & 1.400 & 1.424 & 1.458 & 1.495 \\
\hline $\mathrm{Wt}_{\text {Step }}$ & $\mathrm{g}$ & 618.4 & 541.6 & 02.9 & 474.5 & 446.4 & 421.6 & 397.9 & 374.3 \\
\hline$f_{\mathrm{Liq}}$ & & 1.000 & 0.997 & 0.996 & 0.994 & 0.992 & 0.984 & 0.874 & 0.843 \\
\hline $\operatorname{Vol}_{\mathrm{Liq}}{ }^{1{ }^{\circ} \mathrm{C}}$ & $\mathrm{mL}$ & 488.1 & 411.3 & 373.0 & 344.5 & 316.3 & 291.3 & 238.5 & 211.1 \\
\hline $\mathrm{D}_{\mathrm{Liq}}{ }^{10^{\circ} \mathrm{C}}$ & $\mathrm{g} / \mathrm{mL}$ & 1.267 & 1.318 & 1.348 & 1.371 & 1.400 & 1.421 & 1.427 & 1.431 \\
\hline Wt Liquid & $\mathrm{g}$ & 618.4 & 542.0 & 502.7 & 472.4 & 442.8 & 414.0 & 340.3 & 302.0 \\
\hline Wt Dry Solids & $\mathrm{g}$ & 0.0 & -0.4 & 0.2 & 2.1 & 3.6 & 7.6 & 57.6 & 72.3 \\
\hline Wt\% Dry Soli & & 0.0 & -0.1 & 0.0 & 0.4 & 0.8 & 1.8 & 14.5 & 19.3 \\
\hline Wt $\%$ Wet $18^{\circ}$ & C-Slds & 0.0 & 0.9 & 1.1 & 1.5 & 2.0 & 6.5 & 27.5 & 33.5 \\
\hline
\end{tabular}

6. The wt\% of dry solids in the concentrate is calculated:

(Wt Dry Solids / $\left.\mathrm{Wt}_{\text {Step }}\right)(100)$

Table 5-3. Estimated Dry Weights of Solids in Concentrates at $18{ }^{\circ} \mathrm{C}$.

The liquid fraction, $f_{\text {Liq }}$, was estimated by assuming that the C-Slds from each concentrate contained $50 \mathrm{vol} \%$ solids and $50 \mathrm{vol} \%$ interstitial liquid. This was the same assumption used to calculate the total volume of liquid in the boildown samples at $18.0{ }^{\circ} \mathrm{C}$ (Section 5.1.3).

The calculated wt $\%$ dry solids in the pot concentrates and the wt $\%$ wet $18{ }^{\circ} \mathrm{C} \mathrm{C}$-Slds measured in the boildown samples (from Table 3-3) are compared graphically in Figure 5-8. The two values display a very similar trend in solids weight versus boildown progress. The relative agreement of the calculated and measured solids weights suggests that the volumes and densities measured/calculated in this study are internally consistent and reasonably accurate. 
Figure 5-8. Calculated and Measured Weights of Solids in Concentrates.

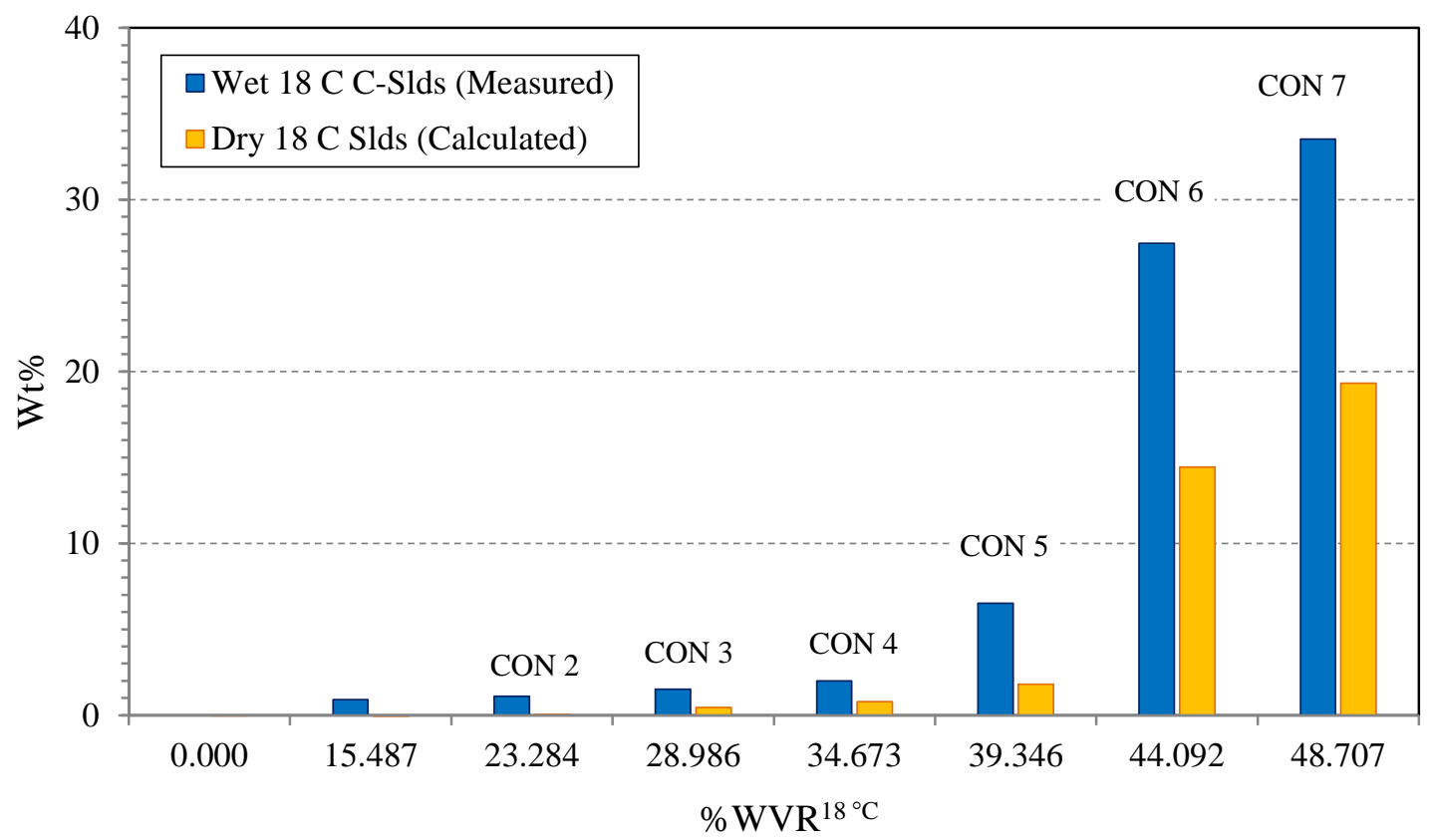

\subsection{COMPOSITION OF BOILDOWN SOLIDS}

\subsubsection{Quantities of Species Remaining in Solution}

Concentrations of chemical species in the C-Liq fractions of the AW-106 test composite and the 10 boildown test samples are tabulated in Table 4-1. In order to better discern how the amounts of the chemical species changed during the progress of the boildown, this data was reformatted to show the estimated total quantities of species in solution after the concentrates were cooled to $18.0{ }^{\circ} \mathrm{C}$.

The total weight of a species present in a pot concentrate is:

$$
\mathrm{Wt}_{\text {Species }}=\mathrm{Wt}_{\text {In solution }}+\mathrm{Wt}_{\text {In precipitated solids }}
$$

From Eq. 3-1, $C R_{\text {Total }}=\mathrm{Vol}_{\text {Composite }} / \mathrm{Vol}_{\text {Pot Concentrate, }}$, the total weight of a species present in a pot concentrate is, therefore:

$$
\mathrm{Wt}_{\text {Species }}=\left[(\mathrm{g} / \mathrm{L})_{\mathrm{C}-\mathrm{Liq}} \times\left(0.4881 \mathrm{~L} / C R^{18^{\circ} \mathrm{C}}\right) \times f_{\mathrm{Liq}}\right]+\left[(\mathrm{g} / \mathrm{L})_{\mathrm{C}-\text {-Slds }} \times\left(0.4881 \mathrm{~L} / C R^{18^{\circ} \mathrm{C}}\right) \times f_{\text {Slds }}\right]
$$

where $f_{\text {Liq }}$ and $f_{\text {Slds }}$ are the volume fractions of liquid and solids in the concentrate.

If a species is not removed from the liquid phase by precipitation (or volatilization) during a boildown, the total weight of the species in a pot concentrate reduces to

$$
\mathrm{Wt}_{\text {Species }}=\mathrm{Wt}_{\text {In Solution }}=(\mathrm{g} / \mathrm{L})_{\mathrm{C}-\mathrm{Liq}} \times\left(0.4881 \mathrm{~L} / C R^{18^{\circ} \mathrm{C}}\right) \times f_{\text {Liq }}
$$


These values are displayed for the boildown samples in Figure 5-9(a)-(u). The 'Constant Wt' line in each plot shows the weight of the species that was present in the $488.1 \mathrm{~mL} \mathrm{AW}-106$ composite added to the pot at the beginning of the boildown test (in cases where the reported result for the CP sample was arbitrarily low, the result for the DIL-3 sample was used instead). As previously noted, values for the test composite (CP) and the volume reduction sequence samples (CON-1 to CON-7) are displayed with solid data markers; values for the dilution sequence samples (DIL-1 to DIL-3) are displayed with hollow data markers of the same shape. Plots for phosphate, bromide, and $\mathrm{Ca}$ are not included because insufficient or no analytical results exceeded reported detection limits. The phosphate plot in Figure 5-9 (k) was generated using the results from the detected phosphorous in solution.

If a species is not removed from the liquid phase by precipitation (or volatilization) during a boildown, the calculated weights for all the samples should plot on or near the Constant Wt line. If a species is removed from solution by precipitation, species weights calculated using Equation 5-10 should fall below the Constant Wt line for some or all of the boildown samples.

Use of a reasonably accurate value of $f_{\text {Liq }}$ is of importance (particularly for highly concentrated species and/or when large quantities of solids are present). However, the values for $f_{\text {Liq }}$ and $f_{\text {SIds }}$ were not directly measured. Values for $f_{\text {Liq }}$ were estimated using the same assumed composition of sample C-Slds - 50 vol\% solids and 50 vol\% interstitial liquid-used in previous calculations (Sections 5.1.3 and 5.3.3).

The errors associated with the displayed weights of species in solution combine analytical errors, errors in determination of $\% \mathrm{WVR}^{18^{\circ} \mathrm{C}}\left(C R^{18^{\circ} \mathrm{C}}\right)$ values, and errors in estimation of $f_{\text {Liq. }}$. The displayed values are, however, of sufficient accuracy to distinguish between changes due to removal/addition of water from/to the boildown pot and changes due to solids formation.

Reported minimum detection limit (MDL) values associated with each species have been converted to minimum detectable weight (MDW) values for each sample in the same manner used to calculate the weights in solution. The MDW values are displayed as small horizontal bars below each data point for the boildown samples.

Complementary to the weights of species in solution are the estimated weights of species in the solids in the $18.0{ }^{\circ} \mathrm{C}$ concentrates. These estimates can be calculated by subtracting the weights of a species remaining in solution from the Constant Wt value. The estimated weights of chemical species that would be found in precipitated solids of the pot concentrates from steps $\mathrm{CON}-5, \mathrm{CON}-6$, and CON-7 which were cooled to $18.0^{\circ} \mathrm{C}$ are displayed in Figure 5-10. (Small negative calculated weights are displayed with red data markers.) 
Figure 5-9. Weights of Species Remaining in Solution at $18{ }^{\circ} \mathrm{C}$. ( 8 sheets)
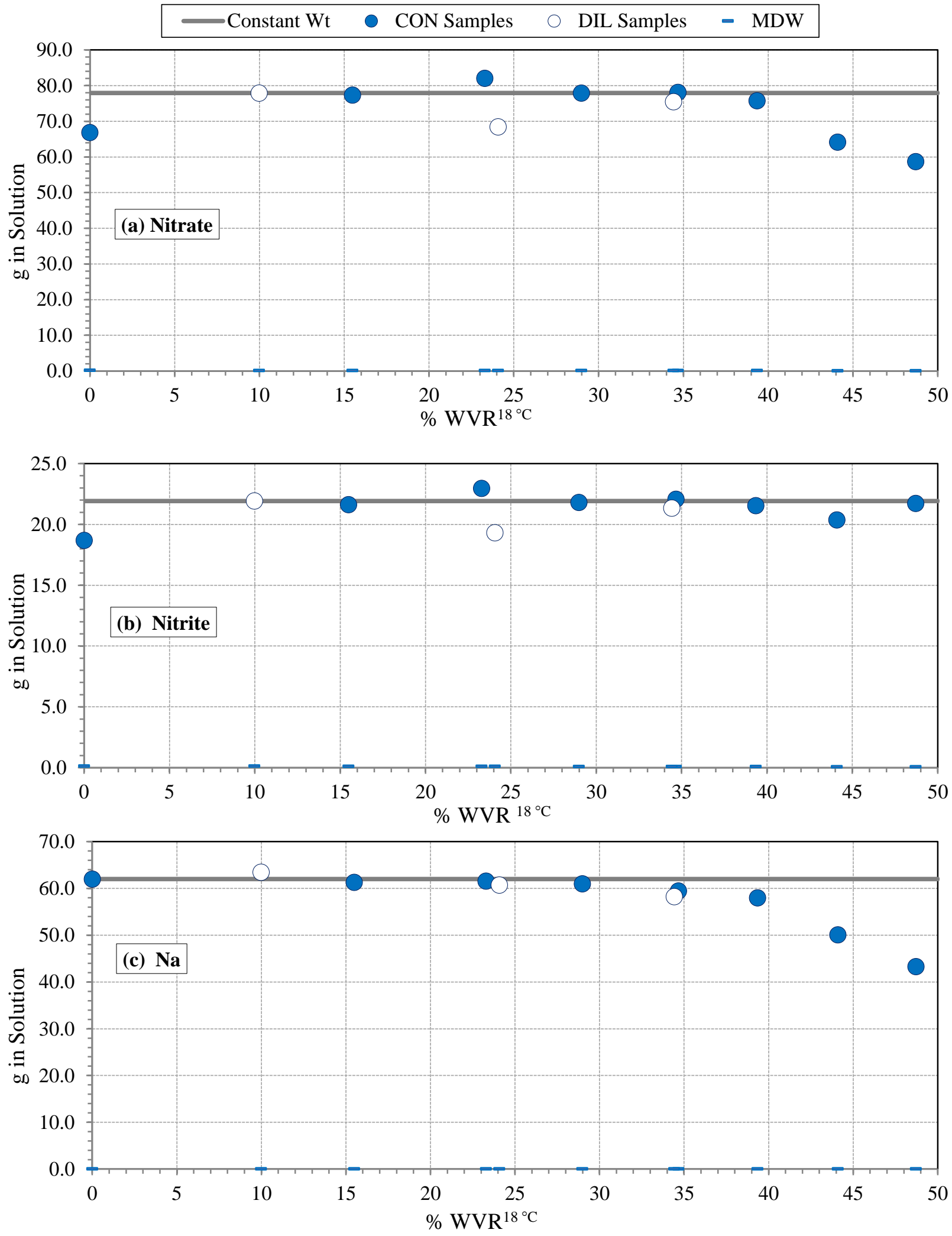
Figure 5-9. Weights of Species Remaining in Solution at $18{ }^{\circ} \mathrm{C}$. (8 sheets)
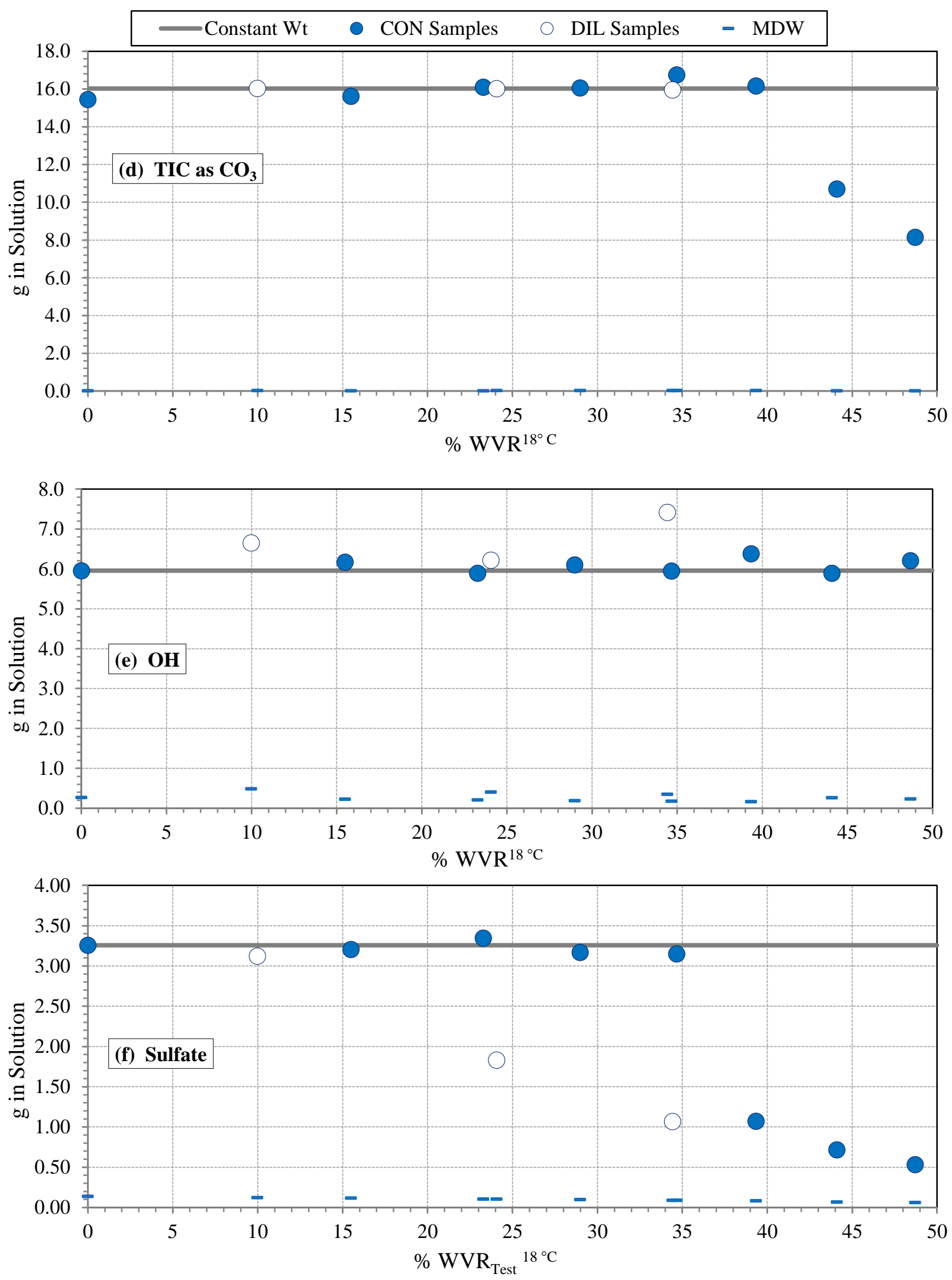
Figure 5-9. Weights of Species Remaining in Solution at $18{ }^{\circ} \mathrm{C}$. (8 sheets)
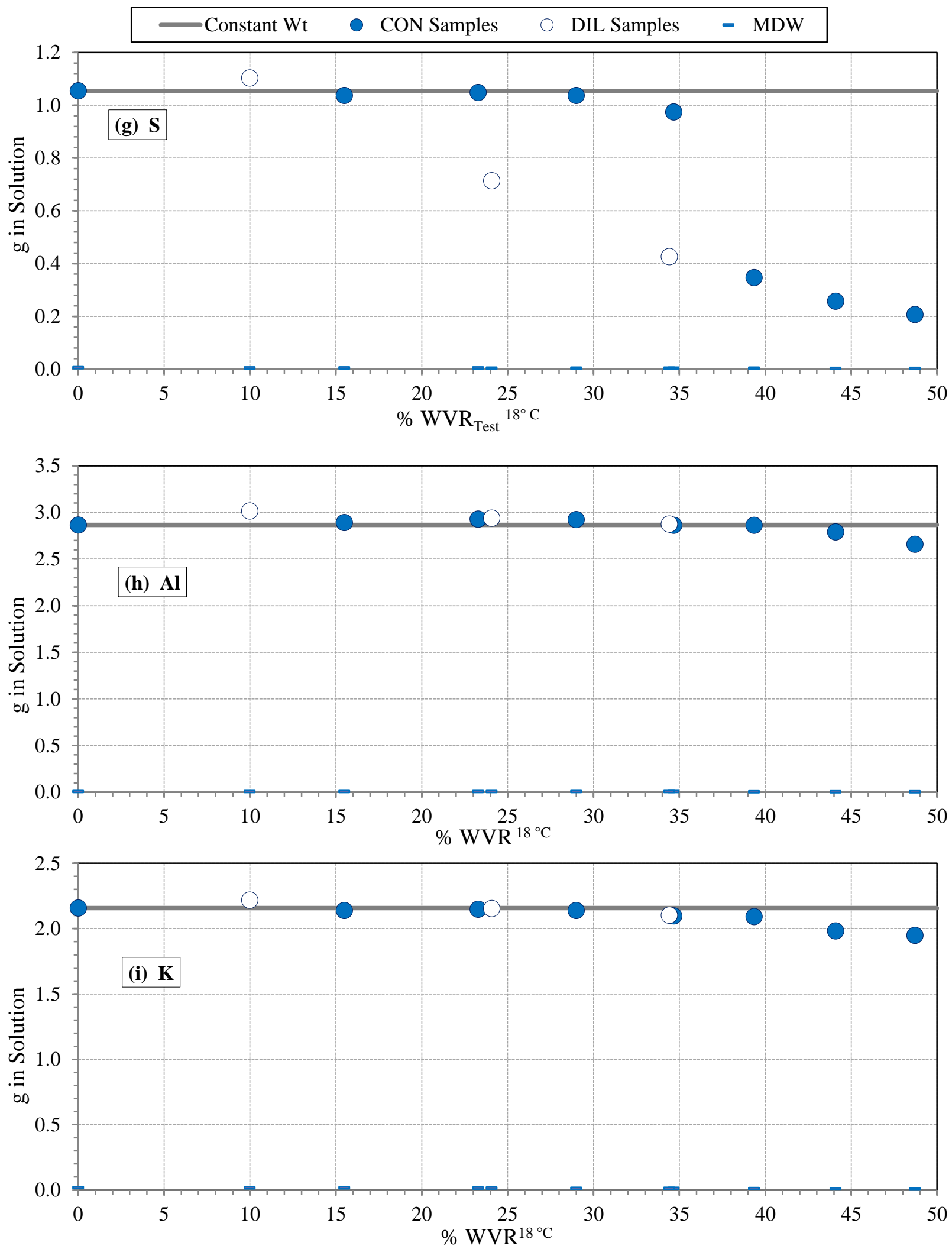
Figure 5-9. Weights of Species Remaining in Solution at $18{ }^{\circ} \mathrm{C}$. ( 8 sheets)
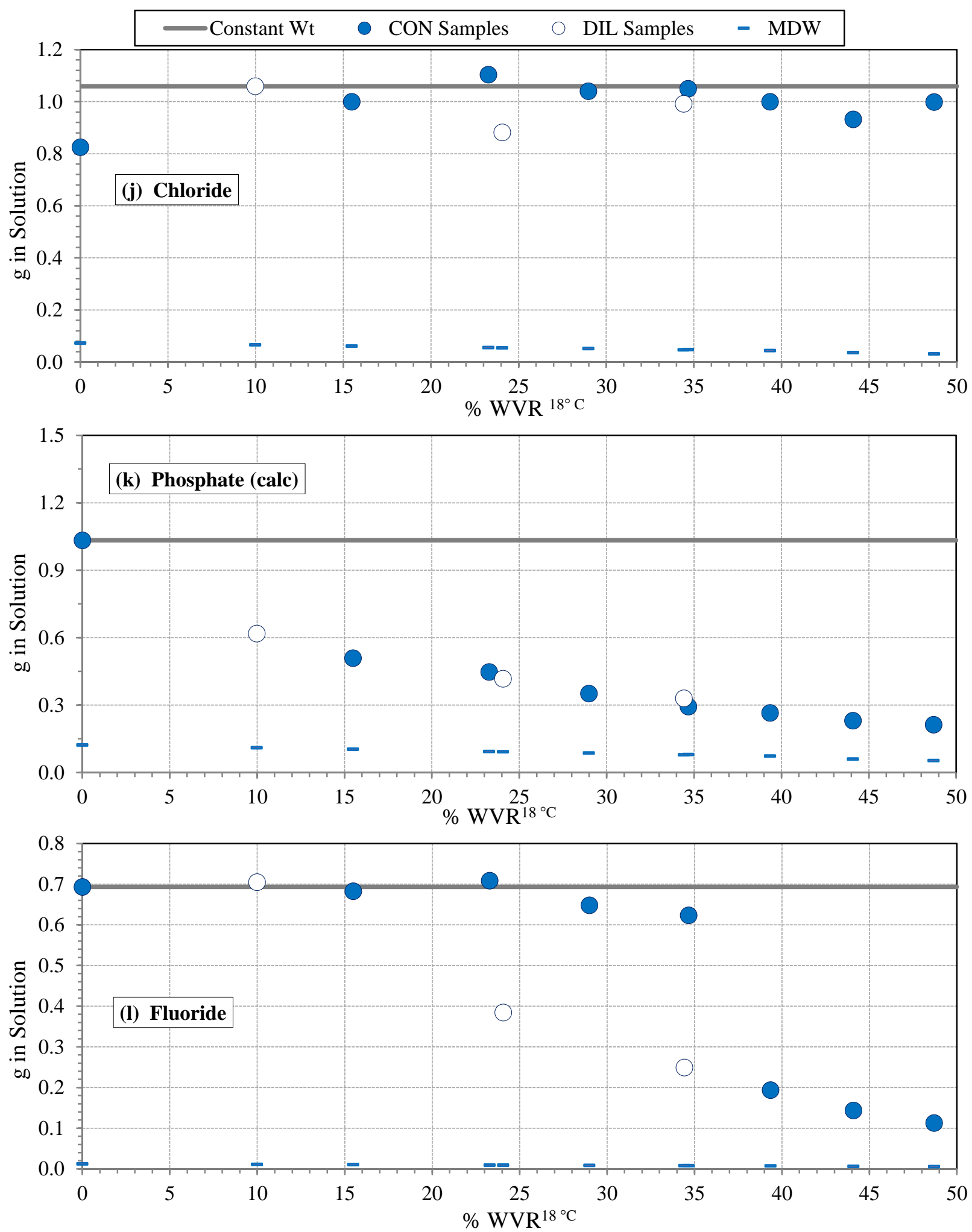
Figure 5-9. Weights of Species Remaining in Solution at $18{ }^{\circ} \mathrm{C}$. ( 8 sheets)
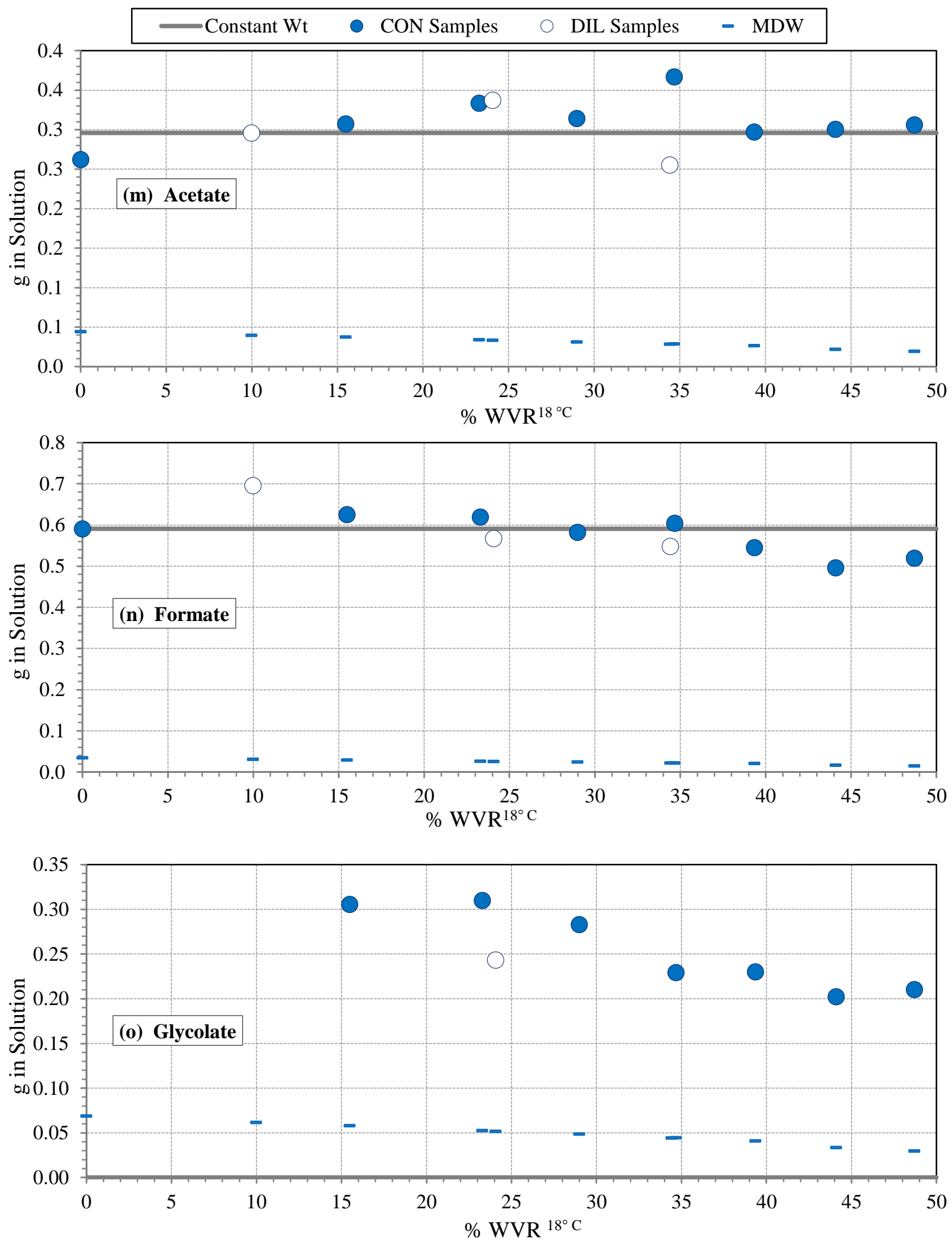
Figure 5-9. Weights of Species Remaining in Solution at $18{ }^{\circ} \mathrm{C}$. (8 sheets)
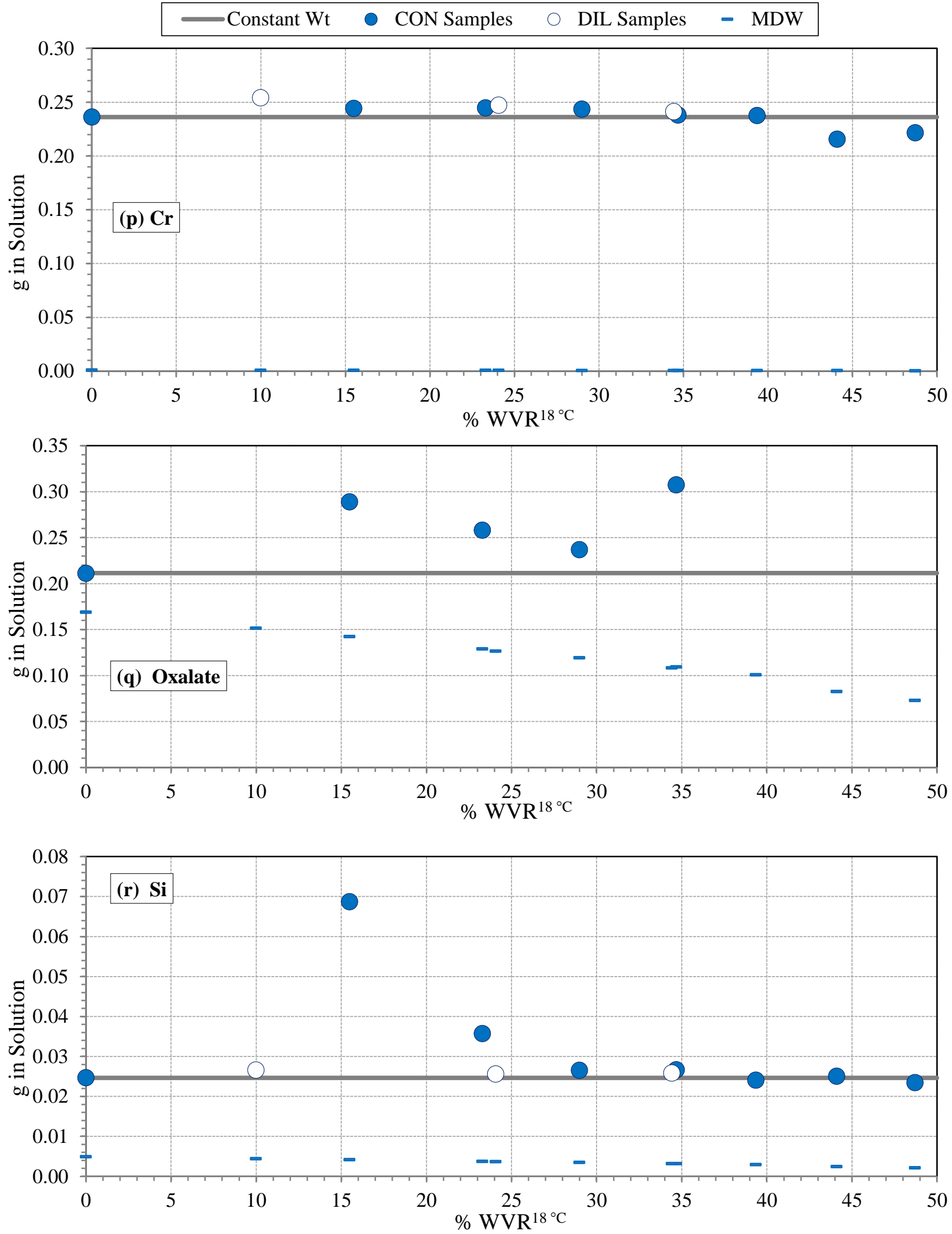
Figure 5-9. Weights of Species Remaining in Solution at $18{ }^{\circ} \mathrm{C}$. ( 8 sheets)
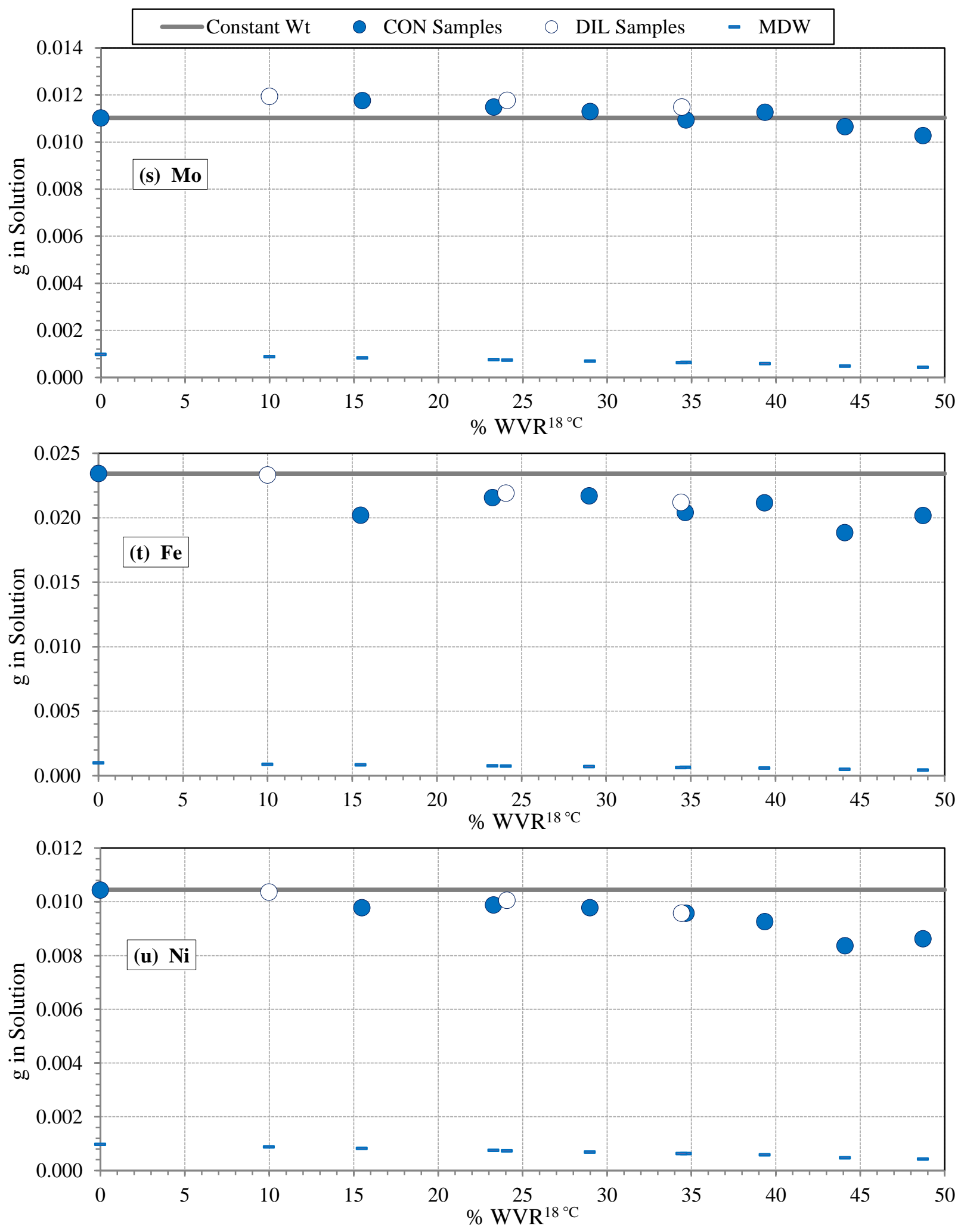
Figure 5-9. Weights of Species Remaining in Solution at $18{ }^{\circ} \mathrm{C}$. (8 sheets)

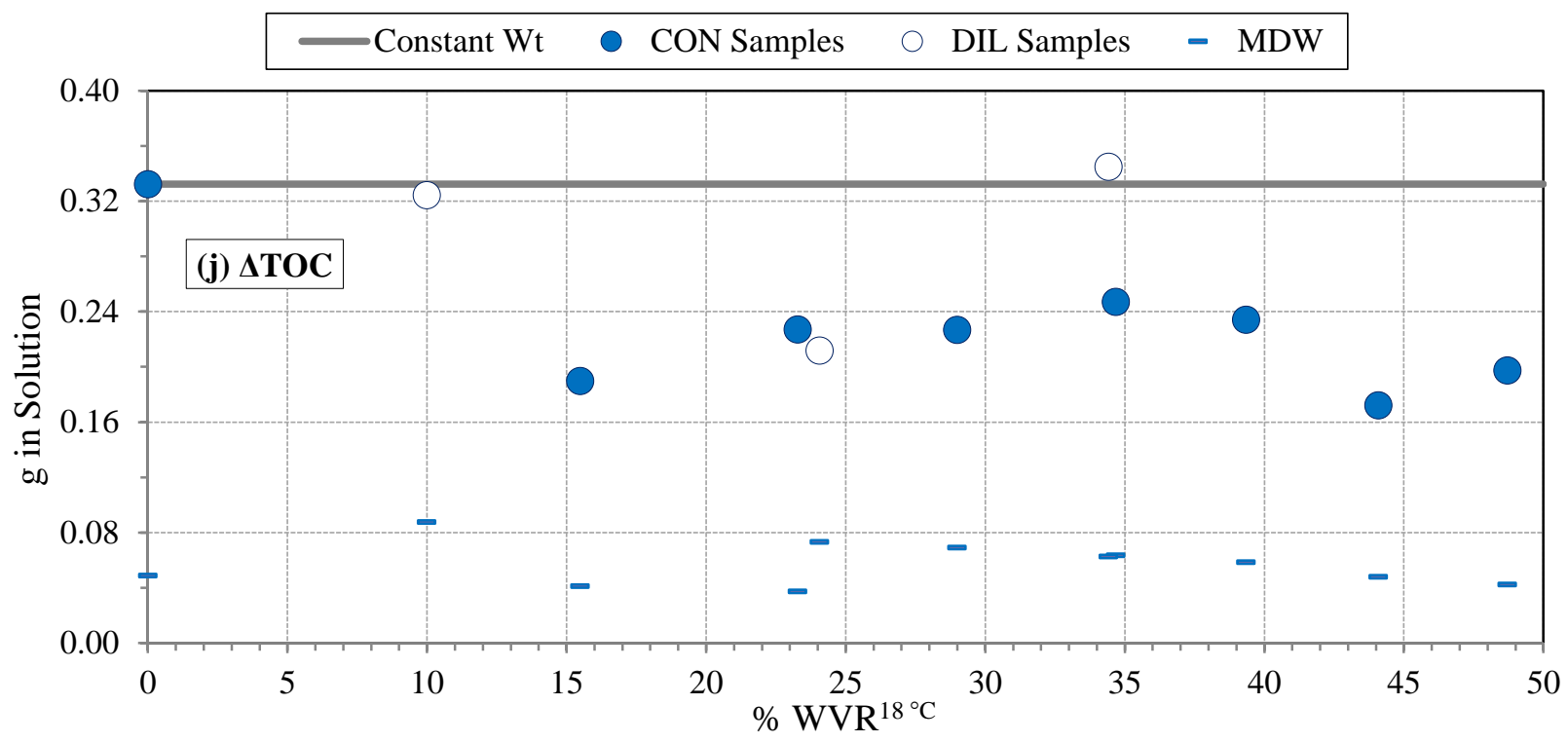


Figure 5-10. Estimated Weights of Species in $18{ }^{\circ} \mathrm{C}$ Solids.
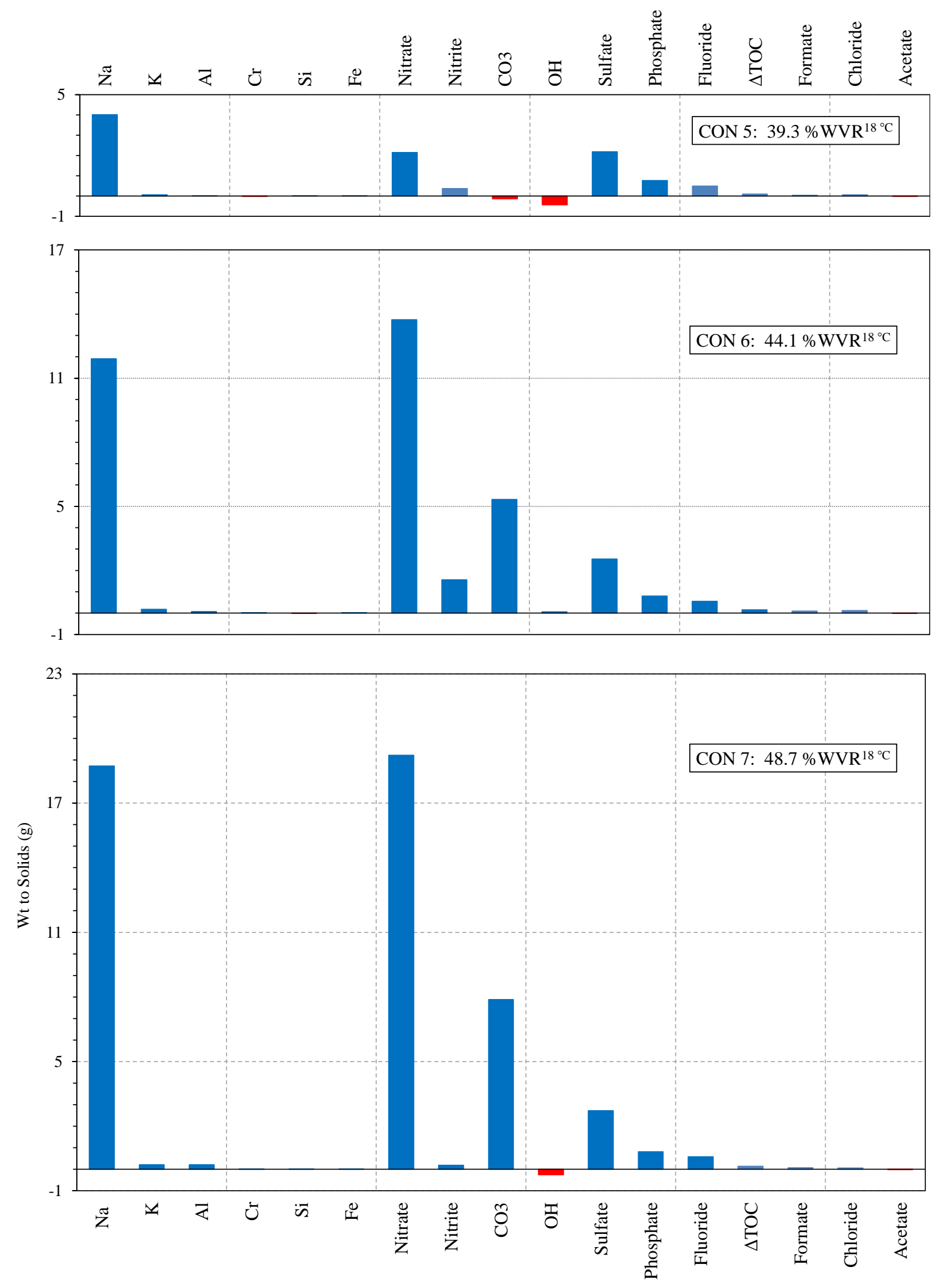
The chemical analysis data indicate that $\mathrm{Cr}, \mathrm{Si}, \mathrm{Fe}, \mathrm{OH}$, formate, chloride, acetate, and glycolate species do not contribute significantly to the solids formed in the boildown concentrates. Based on the changes in solution concentrations, the major species in the solids are predicted to be $\mathrm{Na}$, nitrate, $\mathrm{CO}_{3}$, sulfate, phosphate, and fluoride. The plot for fluoride is also very similar to the plot for sulfate suggesting that these two species co-precipitate.

\subsubsection{Solid Phase Characterization Results}

The 4 samples of C-Slds recovered from the AW-106 boildown samples (as identified in Table 3-2) were submitted to the 222-S Laboratory for SPC to identify solid phases present. Three methods were used: polarized light microscopy (PLM), powder X-ray diffraction (XRD), and scanning electron microscopy with energy-dispersive X-ray spectrometry (SEM/EDX). The SPC analyses were performed by members of the 222-S Special Analytical Services and Process Chemistry groups. Analysis results for the three SPC methods, including photographs and spectra, are presented in Attachment E.

The results of the SPC analyses are summarized in Table 5-4. The quantity descriptors are those used by the analysts in the method-specific reports.

Each of the SPC methods is limited to examination of very small quantities of solids. Homogenization and subsampling of radiologically "hot" samples to collect representative specimens of the required weight/volume is difficult at best. The tabulated results in Table 5-4 are also based on analysis of a single specimen for each method. In addition, specimens for XRD and SEM/EDX analyses are dried during preparation, and solids dissolved in the liquids collected with the samples may precipitate and complicate interpretation of analysis results. For these reasons, the results of the SPC analyses are only considered qualitative and not quantitative.

The solid phase composition of the first three samples, i.e., the C-Slds from the samples preceding and including the end-point slurry, represent the accumulating inventory of solids in the boildown pot during the volume reduction sequence. The final sample [Table 5-4(d)] shows the solid phases that remain after dilution of the end-point slurry solids was complete. 
Table 5-4. Solid Phases Identified in C-SIds Samples. (2 sheets)

(a) S13T001244: Composite of C-Slds from Samples CON-3, CON-4, and CON-5 (39.3\%WVR $\left.18^{\circ} \mathrm{C}\right)$

\begin{tabular}{|c|c|c|c|c|}
\hline \multirow[b]{2}{*}{ Solid Phase } & \multirow[b]{2}{*}{ Formula } & \multicolumn{3}{|c|}{ Observations of Characterization Technique } \\
\hline & & XRD & SEM/EDX & PLM \\
\hline $\begin{array}{l}\text { Thermonatrite } \\
\text { (sodium carbonate monohydrate) }\end{array}$ & $\mathrm{Na}_{2} \mathrm{CO}_{3} \cdot \mathrm{H}_{2} \mathrm{O}$ & Major & Moderate & Moderate \\
\hline $\begin{array}{l}\text { Natrophosphate } \\
\text { (sodium fluoride phosphate hydrate) }\end{array}$ & $\mathrm{Na}_{7} \mathrm{~F}\left(\mathrm{PO}_{4}\right)_{2} \cdot 19 \mathrm{H}_{2} \mathrm{O}$ & Major & Major & Major \\
\hline $\begin{array}{l}\text { Kogarkoite } \\
\text { (sodium fluoride sulfate) }\end{array}$ & $\mathrm{Na}_{3} \mathrm{FSO}_{4}$ & Minor & Major & Major \\
\hline Sodium nitrate & $\mathrm{NaNO}_{3}$ & Major $^{a}$ & - & - \\
\hline Sodium nitrite & $\mathrm{NaNO}_{2}$ & Minor $^{a}$ & - & - \\
\hline
\end{tabular}

${ }^{\text {a }}$ Identified as a probable specimen preparation artifact where solids dissolved in the liquid collected with the sample precipitated upon drying.

(b) S13T001245: C-Slds from Sample CON-6 (44.1\% WVR $\left.{ }^{18^{\circ} \mathrm{C}}\right)$

\begin{tabular}{|c|c|c|c|c|}
\hline \multirow[b]{2}{*}{ Solid Phase } & \multirow[b]{2}{*}{ Formula } & \multicolumn{3}{|c|}{ Observations of Characterization Technique } \\
\hline & & XRD & SEM/EDX & PLM \\
\hline Thermonatrite & $\mathrm{Na}_{2} \mathrm{CO}_{3} \cdot \mathrm{H}_{2} \mathrm{O}$ & Minor & Major & Major \\
\hline Natrophosphate & $\mathrm{Na}_{7} \mathrm{~F}\left(\mathrm{PO}_{4}\right)_{2} \cdot 19 \mathrm{H}_{2} \mathrm{O}$ & Minor & Moderate & Moderate \\
\hline Kogarkoite & $\mathrm{Na}_{3} \mathrm{FSO}_{4}$ & Minor & Moderate & Moderate \\
\hline $\begin{array}{l}\text { Natroxalate } \\
\text { (sodium oxalate) }\end{array}$ & $\mathrm{Na}_{2} \mathrm{C}_{2} \mathrm{O}_{4}$ & - & - & Minor \\
\hline Sodium nitrate & $\mathrm{NaNO}_{3}$ & Major $^{a}$ & Trace & Trace \\
\hline Sodium nitrite & $\mathrm{NaNO}_{2}$ & Minor $^{a}$ & - & - \\
\hline
\end{tabular}

${ }^{\mathrm{a}}$ Identified as a probable specimen preparation artifact where solids dissolved in the liquid collected with the sample precipitated upon drying.

(c) S13T001246: C-Slds from end point slurry Sample CON-7 $\left(48.7 \% \mathrm{WVR}^{18^{\circ} \mathrm{C}}\right)$

\begin{tabular}{|c|c|c|c|c|}
\hline \multirow[b]{2}{*}{ Solid Phase } & \multirow[b]{2}{*}{ Formula } & \multicolumn{3}{|c|}{ Observations of Characterization Technique } \\
\hline & & XRD & SEM/EDX & PLM \\
\hline Thermonatrite & $\mathrm{Na}_{2} \mathrm{CO}_{3} \cdot \mathrm{H}_{2} \mathrm{O}$ & Major & Major & Major \\
\hline Natrophosphate & $\mathrm{Na}_{7} \mathrm{~F}\left(\mathrm{PO}_{4}\right)_{2} \cdot 19 \mathrm{H}_{2} \mathrm{O}$ & Minor & Minor & Minor \\
\hline Kogarkoite & $\mathrm{Na}_{3} \mathrm{FSO}_{4}$ & Minor & Minor & Minor \\
\hline Natroxalate & $\mathrm{Na}_{2} \mathrm{C}_{2} \mathrm{O}_{4}$ & - & - & Minor \\
\hline Sodium nitrate & $\mathrm{NaNO}_{3}$ & Major $^{a}$ & - & Trace \\
\hline Sodium nitrite & $\mathrm{NaNO}_{2}$ & Minor $^{\mathrm{a}}$ & - & - \\
\hline
\end{tabular}

${ }^{a}$ Identified as a probable specimen preparation artifact where solids dissolved in the liquid collected with the sample precipitated upon drying. 
LAB-RPT-13-00003 R0

Table 5-4. Solid Phases Identified in C-SIds Samples. (2 sheets)

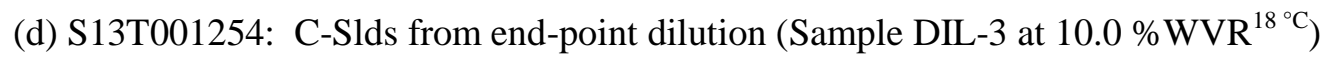

\begin{tabular}{|c|c|c|c|c|}
\hline \multirow[b]{2}{*}{ Solid Phase } & \multirow[b]{2}{*}{ Formula } & \multicolumn{3}{|c|}{ Observations of Characterization Technique } \\
\hline & & XRD & SEM/EDX & PLM \\
\hline Natroxalate & $\mathrm{Na}_{2} \mathrm{C}_{2} \mathrm{O}_{4}$ & Major & Major & Major \\
\hline Natrophosphate & $\mathrm{Na}_{7} \mathrm{~F}\left(\mathrm{PO}_{4}\right)_{2} \cdot 19 \mathrm{H}_{2} \mathrm{O}$ & Minor & Minor & Minor \\
\hline Kogarkoite & $\mathrm{Na}_{3} \mathrm{FSO}_{4}$ & - & - & Minor \\
\hline Thermonatrite & $\mathrm{Na}_{2} \mathrm{CO}_{3} \cdot \mathrm{H}_{2} \mathrm{O}$ & Major & - & Trace \\
\hline Sodium nitrate & $\mathrm{NaNO}_{3}$ & Major $^{a}$ & - & - \\
\hline Sodium nitrite & $\mathrm{NaNO}_{2}{ }^{\mathrm{a}}$ & Minor $^{a}$ & - & - \\
\hline
\end{tabular}

${ }^{\text {a }}$ Identified as a probable specimen preparation artifact where solids dissolved in the liquid collected with the sample precipitated upon drying.

\subsubsection{Solid Phases Present in Concentrate Solids}

In Figure 5-11, the chemical analysis data of Section 5.4.1 and the SPC results of Section 5.4.2 are combined. The estimated weights of the chemical species in the solid fractions of the $18.0^{\circ} \mathrm{C}$ concentrates (displayed in Figure 5-10) were first converted to weights of solid phases identified in SPC analysis. The weights of the solid phases were then adjusted so the sums of the phase weights for each boildown step were equal to the estimated dry solids weights calculated in Section 5.3.3. The adjusted phase weights were then converted to solid phase volumes by dividing by the reference densities of the solid phases.

In general, the $\mathrm{AW}-106$ boildown testing indicates that kogarkoite $\left(\mathrm{Na}_{3} \mathrm{FSO}_{4}\right)$, natrophosphate $\left[\mathrm{Na}_{7} \mathrm{~F}\left(\mathrm{PO}_{4}\right)_{2} \cdot 19 \mathrm{H}_{2} \mathrm{O}\right]$, and sodium nitrate are the first species to precipitate from the composite as it is reduced, and given sufficient time/nucleation sites, natrophosphate can form earlier than when solids first appeared in the boildown apparatus at $39.3 \% \mathrm{WVR}$.

By CON-6, 44.1\%WVR, much of the phosphate, sulfate, and fluoride is depleted from the solution ( $\sim 80 \%$ for each species), and the next major species to form are sodium nitrate and sodium carbonate $\left(\mathrm{Na}_{2} \mathrm{CO}_{3} \bullet \mathrm{H}_{2} \mathrm{O}\right)$.

During dilution of the endpoint slurry, sodium nitrate, sodium carbonate, and natrophosphate readily dissolve, and the kogarkoite does go back into solution but at a much lower rate. Eventually, by DIL-3, sodium oxalate remains as the major component of the solids. Sodium oxalate was observed in trace amounts in the concentration samples by only one of the SPC methods due to the relative small amounts present compared to the other species in the solids. 
Figure 5-11. Estimated Vol\% of Solid Phases in Concentrate Solids.
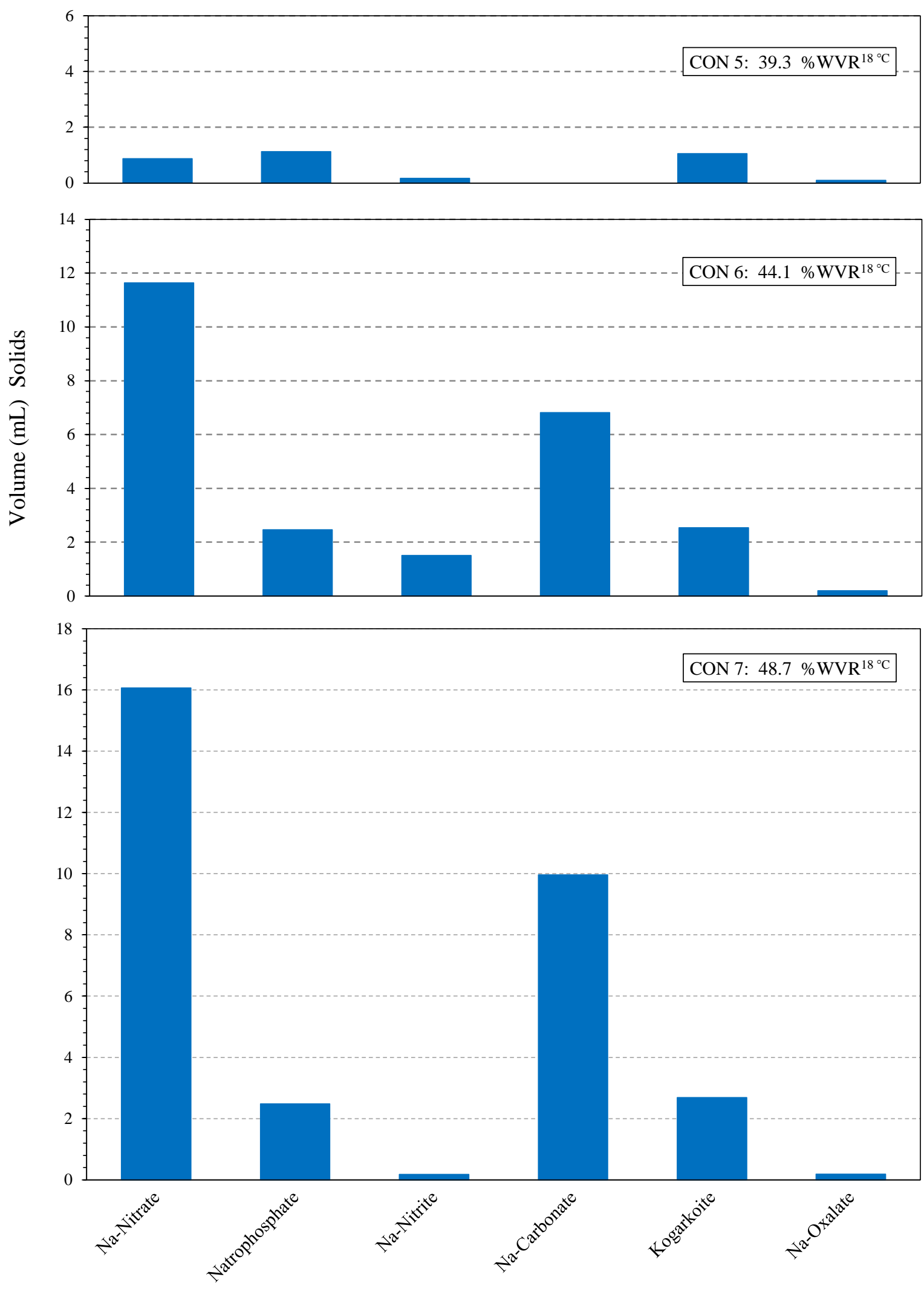
LAB-RPT-13-00003 R0

\section{QUALITY ASSURANCE}

\subsection{HOT CELL OPERATIONS}

As discussed in Section 2.2, temperature measurements recorded during the hot cell boildown operations were corrected to true readings provided by a certified, Pt-resistance (RTD) thermometer. The Certificate of Calibration for this reference thermometer was issued September 5, 2012 and is valid for 1 year. A copy of the calibration certificate is included in the project file.

Pressure measurements in the hot cell operations were indirectly calibrated through the verified temperature readings. The measured pressures over pure water boiling at measured temperatures were compared with tabulated vapor pressures of pure water at the same temperatures.

The in-tolerance status of each analytical balance used during the boildown study was verified at a minimum of $\pm 0.1 \%$ before use or daily, whichever was less frequent (ATS-LO-140-008, "222S Laboratory Routine Use and Quality Assurance for Analytical Balances at 222-S Laboratory Complex"). The calibration verification measurements were recorded on Balance Calibration Verification Check Sheets. Copies of the check sheets are included in the project file.

\subsection{LABORATORY ANALYSES}

Quality control measurements required to ensure the quality of the analyses of the boildown samples performed at the 222-S Laboratory are specified in ATS-MP-1032, 222-S Laboratory Quality Assurance Project Plan, and in ATL-MP-1011, ATL Quality Assurance Project Plan for 222-S Laboratory. The results of all quality control measurements performed are included in the transcript of the analytical results presented in Attachment D.

\subsection{DEVIATIONS FROM TEST PLAN}

The AW-106 boildown study was executed, in general, as described in the client-approved laboratory test plan (LAB-PLN-13-00001). The test plan incorporated some minor deviations from the guidance for completion of the boildown study provided in the TSAP

(RPP-PLAN-53006); these changes were executed with the concurrence of the 242-A Evaporator Technical Point of Contact. 


\section{REFERENCES}

ATL-MP-1011, Rev. 9, ATL Quality Assurance Project Plan for 222-S Laboratory, Advanced Technologies and Laboratories International, Inc., Richland, Washington.

ATS-LO-140-008, Rev. N-0, "Routine Use and Quality Assurance for Analytical Balances at 222-S Laboratory Complex,” Washington River Protection Solutions LLC, Richland, Washington.

ATS-LT-519-183, Rev. F-0, “222-S Laboratory Determination of Properties of Radiological Solutions as a Function of Volume Reduction at Reduced Pressure," Washington River Protection Solutions LLC, Richland, Washington.

ATS-MP-1032, Rev. D-1, 222-S Laboratory Quality Assurance Project Plan, Washington River Protection Solutions LLC, Richland, Washington.

LAB-PLN-13-00001, 2013, Test Plan for Boildown Study on Supernate Retrieved from Tank 241-AW-106 in December 2012, Rev. 0, Washington River Protection Solutions LLC, Richland, Washington.

LAB-RPT-12-00008, 2012, Boildown Study on Supernatant Liquid Retrieved from AP-107 in May 2010, Rev. 0, Washington River Protection Solutions LLC, Richland, Washington.

MEM-052174, 1974, "Densities of Caustic Waste Solutions as a Function of Temperature," (Internal memorandum from J. S. Buckingham to H. F. Jensen, May 21), Atlantic Richfield Hanford Company, Richland, Washington.

RPP-PLAN-53006, 2012, Tank 241-AW-106 Grab Sampling and Analysis Plan in Support of Evaporator Campaign for Fiscal Year 2013, Rev. 2, Washington River Protection Solutions LLC, Richland, Washington.

RPP-RPT-54430, 2013, Final Report for Tank 241-AW-106 Grab Samples in Support of Evaporator Campaign for Fiscal Year 2013, Rev. 0, prepared for Washington River Protection Solutions LLC by ATL International, Inc., Richland, Washington.

WRPS-0900372, 2009, "Results of Lifetime Testing of Anton Paar DMA 35N Portable Density Meter," (internal memorandum from W. S. Callaway to C. M. Seidel, March 23), Washington River Protection Solutions LLC, Richland, Washington. 
LAB-RPT-13-00003 R0

ATTACHMENT A

VOLUME CALIBRATION OF CENTRIFUGE CONES 
LAB-RPT-13-00003 R0

Attachment A

\section{VOLUME CALIBRATIONS OF CENTRIFUGE CONES}

The volumes read ( $\mathrm{Vol}_{\text {Read }}$ ) from gradations on the $15-\mathrm{mL}$ centrifuge cones used to collect the boildown samples were adjusted to corrected values ( Vol $\left._{\text {Corrected }}\right)$. The volumetric and gravimetric data collected and calculations performed in deriving the correction functions are presented in Table A-1.

Table A-1. Centrifuge Cone Volume Calibrations. (4 sheets)

\begin{tabular}{|c|c|c|c|c|c|c|c|}
\hline \multirow{3}{*}{ Cone ID } & \multirow{3}{*}{ Cal Date } & \multirow{2}{*}{\multicolumn{2}{|c|}{$\mathrm{H}_{2} \mathrm{O}$}} & \multirow{2}{*}{$\begin{array}{r}\text { ConeVol } \\
\mathrm{Wt} \mathrm{H}_{2} \mathrm{O} \text { Added } \\
\end{array}$} & \multicolumn{3}{|c|}{$=$ Volume Read on Cone $(\mathrm{mL})$} \\
\hline & & & & & \multicolumn{3}{|c|}{$=\mathrm{Wt}_{2} \mathrm{O}$ Added to Cone $(\mathrm{g})$} \\
\hline & & $\mathrm{T}\left({ }^{\circ} \mathrm{C}\right)$ & $\mathrm{D}(\mathrm{g} / \mathrm{mL})$ & Vol $\mathrm{H}_{2} \mathrm{O}$ Added & \multicolumn{3}{|c|}{$=\mathrm{Wt} \mathrm{H}_{2} \mathrm{O}(\mathrm{g}) / \mathrm{D} \mathrm{H}_{2} \mathrm{O}(\mathrm{g} / \mathrm{mL})$} \\
\hline \multirow{6}{*}{$\begin{array}{l}\text { AW-106 } \\
\text { BLDN } \\
\text { Cone } 2\end{array}$} & \multirow{3}{*}{$11 / 12 / 12$} & \multirow{3}{*}{22.3} & \multirow{3}{*}{0.99770} & Cone Vol $(\mathrm{mL})$ & 10.10 & 12.06 & 14.03 \\
\hline & & & & Wt $\mathrm{H}_{2} \mathrm{O}$ Added $(\mathrm{g})$ & 9.97774 & 11.93578 & 13.85823 \\
\hline & & & & $\mathrm{Vol} \mathrm{H} \mathrm{H}_{2} \mathrm{O}(\mathrm{mL})$ & 10.0010 & 11.9633 & 13.8898 \\
\hline & \multirow{3}{*}{$11 / 13 / 12$} & \multirow{3}{*}{20.4} & \multirow{3}{*}{0.99812} & Cone Vol (mL) & 10.09 & 12.00 & 13.98 \\
\hline & & & & Wt $\mathrm{H}_{2} \mathrm{O}$ Added (g) & 9.98991 & 11.90236 & 13.80422 \\
\hline & & & & $\mathrm{Vol} \mathrm{H}{ }_{2} \mathrm{O}(\mathrm{mL})$ & 10.0087 & 11.9248 & 13.8302 \\
\hline \multicolumn{4}{|c|}{ one 2 - Sample DIL-3 } & \multicolumn{4}{|c|}{$\mathrm{Vol}_{\text {Corrected }}=\left(0.99 \times \mathrm{Vol}_{\text {Read }}\right)+0.06$} \\
\hline
\end{tabular}

\begin{tabular}{|c|c|c|c|c|c|c|c|}
\hline \multirow{3}{*}{ Cone ID } & \multirow{3}{*}{ Cal Date } & \multirow{2}{*}{\multicolumn{2}{|c|}{$\mathrm{H}_{2} \mathrm{O}$}} & ConeVol & \multicolumn{3}{|c|}{$=$ Volume Read on Cone $(\mathrm{mL})$} \\
\hline & & & & Wt $\mathrm{H}_{2} \mathrm{O}$ Added & \multicolumn{3}{|c|}{$=\mathrm{Wt}_{2} \mathrm{O}$ Added to Cone $(\mathrm{g})$} \\
\hline & & $\mathrm{T}\left({ }^{\circ} \mathrm{C}\right)$ & $\mathrm{D}(\mathrm{g} / \mathrm{mL})$ & Vol $\mathrm{H}_{2} \mathrm{O}$ Added & \multicolumn{3}{|c|}{$=\mathrm{Wt} \mathrm{H}_{2} \mathrm{O}(\mathrm{g}) / \mathrm{D} \mathrm{H}_{2} \mathrm{O}(\mathrm{g} / \mathrm{mL})$} \\
\hline \multirow{6}{*}{$\begin{array}{c}\text { AW-106 } \\
\text { BLDN } \\
\text { Cone } 3\end{array}$} & \multirow{3}{*}{$11 / 12 / 12$} & \multirow{3}{*}{22.1} & \multirow{3}{*}{0.99775} & Cone Vol (mL) & 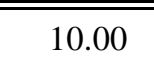 & 12.00 & 13.94 \\
\hline & & & & Wt $\mathrm{H}_{2} \mathrm{O}$ Added $(\mathrm{g})$ & 9.88795 & 11.87520 & 13.73602 \\
\hline & & & & $\mathrm{Vol} \mathrm{H}_{2} \mathrm{O}(\mathrm{mL})$ & 9.9105 & 11.9020 & 13.7670 \\
\hline & \multirow{3}{*}{$11 / 13 / 12$} & \multirow{3}{*}{20.4} & \multirow{3}{*}{0.99812} & Cone Vol (mL) & 10.05 & 12.05 & 14.00 \\
\hline & & & & Wt $\mathrm{H}_{2} \mathrm{O}$ Added $(\mathrm{g})$ & 9.93861 & 11.88029 & 13.77412 \\
\hline & & & & $\mathrm{Vol} \mathrm{H} \mathrm{H}_{2} \mathrm{O}(\mathrm{mL})$ & 9.9573 & 11.9027 & 13.8001 \\
\hline \multicolumn{4}{|c|}{ Cone 3 - Sample CON-3 } & \multicolumn{4}{|c|}{$\mathrm{Vol}_{\text {Corrected }}=\left(0.98 \times \mathrm{Vol}_{\text {Read }}\right)+0.16$} \\
\hline
\end{tabular}


LAB-RPT-13-00003 R0 Attachment A

Table A-1. Centrifuge Cone Volume Calibrations. (4 sheets)

\begin{tabular}{|c|c|c|c|c|c|c|c|}
\hline \multirow{3}{*}{ Cone ID } & \multirow{3}{*}{ Cal Date } & \multirow{2}{*}{\multicolumn{2}{|c|}{$\mathrm{H}_{2} \mathrm{O}$}} & \multicolumn{4}{|c|}{$=$ Volume Read on Cone $(\mathrm{mL})$} \\
\hline & & & & $\mathrm{Wt} \mathrm{H}_{2} \mathrm{O}$ Added & \multicolumn{3}{|c|}{$=\mathrm{Wt} \mathrm{H}_{2} \mathrm{O}$ Added to Cone $(\mathrm{g})$} \\
\hline & & $\mathrm{T}\left({ }^{\circ} \mathrm{C}\right)$ & $\mathrm{D}(\mathrm{g} / \mathrm{mL})$ & Vol $\mathrm{H}_{2} \mathrm{O}$ Added & \multicolumn{3}{|c|}{$=\mathrm{Wt} \mathrm{H}_{2} \mathrm{O}(\mathrm{g}) / \mathrm{D} \mathrm{H}_{2} \mathrm{O}(\mathrm{g} / \mathrm{mL})$} \\
\hline \multirow{6}{*}{$\begin{array}{l}\text { AW-106 } \\
\text { BLDN } \\
\text { Cone } 4\end{array}$} & \multirow{3}{*}{$11 / 16 / 12$} & \multirow{3}{*}{21.0} & \multirow{3}{*}{0.99799} & Cone Vol $(\mathrm{mL})$ & 10.00 & 12.05 & 14.12 \\
\hline & & & & $\mathrm{Wt} \mathrm{H}_{2} \mathrm{O}$ Added $(\mathrm{g})$ & 9.95792 & 11.98409 & 13.95255 \\
\hline & & & & $\mathrm{Vol} \mathrm{H}_{2} \mathrm{O}(\mathrm{mL})$ & 9.9780 & 12.0082 & 13.9806 \\
\hline & \multirow{3}{*}{$11 / 16 / 12$} & \multirow{3}{*}{21.0} & \multirow{3}{*}{0.9979} & Cone Vol $(\mathrm{mL})$ & 10.09 & 12.02 & 14.05 \\
\hline & & & & Wt $\mathrm{H}_{2} \mathrm{O}$ Added $(\mathrm{g})$ & 10.04527 & 11.93698 & 13.87498 \\
\hline & & & & $\mathrm{Vol} \mathrm{H}_{2} \mathrm{O}(\mathrm{mL})$ & 10.0655 & 11.9610 & 13.9029 \\
\hline \multicolumn{4}{|c|}{ Cone 4 - Sample CON-4 } & \multicolumn{4}{|c|}{$\operatorname{Vol}_{\text {Corrected }}=\left(0.97 \times \mathrm{Vol}_{\text {Read }}\right)+0.29$} \\
\hline
\end{tabular}

\begin{tabular}{|c|c|c|c|c|c|c|c|}
\hline \multirow{3}{*}{ Cone ID } & \multirow{3}{*}{ Cal Date } & \multirow{2}{*}{\multicolumn{2}{|c|}{$\mathrm{H}_{2} \mathrm{O}$}} & \multirow{2}{*}{$\begin{array}{r}\text { ConeVol } \\
\mathrm{Wt} \mathrm{H}_{2} \mathrm{O} \text { Added }\end{array}$} & \multicolumn{3}{|c|}{$=$ Volume Read on Cone $(\mathrm{mL})$} \\
\hline & & & & & \multicolumn{3}{|c|}{$=\mathrm{Wt} \mathrm{H}_{2} \mathrm{O}$ Added to Cone $(\mathrm{g})$} \\
\hline & & $\mathrm{T}\left({ }^{\circ} \mathrm{C}\right)$ & $\mathrm{D}(\mathrm{g} / \mathrm{mL})$ & Vol $\mathrm{H}_{2} \mathrm{O}$ Added & \multicolumn{3}{|c|}{$=\mathrm{Wt} \mathrm{H}_{2} \mathrm{O}(\mathrm{g}) / \mathrm{D} \mathrm{H}_{2} \mathrm{O}(\mathrm{g} / \mathrm{mL})$} \\
\hline \multirow{6}{*}{$\begin{array}{l}\text { AW-106 } \\
\text { BLDN } \\
\text { Cone } 5\end{array}$} & \multirow{3}{*}{$11 / 12 / 12$} & \multirow{3}{*}{21.9} & \multirow{3}{*}{0.99779} & Cone Vol (mL) & 10.05 & 12.05 & 13.98 \\
\hline & & & & Wt $\mathrm{H}_{2} \mathrm{O}$ Added (g) & 9.95465 & 11.91992 & 13.82598 \\
\hline & & & & $\mathrm{Vol} \mathrm{H}_{2} \mathrm{O}(\mathrm{mL})$ & 9.9767 & 11.9463 & 13.8566 \\
\hline & \multirow{3}{*}{$11 / 13 / 12$} & \multirow{3}{*}{20.5} & \multirow{3}{*}{0.99810} & Cone Vol (mL) & 10.02 & 12.05 & 13.95 \\
\hline & & & & Wt $\mathrm{H}_{2} \mathrm{O}$ Added (g) & 9.95389 & 11.92570 & 13.79276 \\
\hline & & & & $\mathrm{Vol} \mathrm{H}_{2} \mathrm{O}(\mathrm{mL})$ & 9.9728 & 11.9484 & 13.8190 \\
\hline \multicolumn{4}{|c|}{ Cone 5 - Sample CON-5 } & \multicolumn{4}{|c|}{$\mathrm{Vol}_{\text {Corrected }}=\left(0.98 \times \mathrm{Vol}_{\text {Read }}\right)+0.11$} \\
\hline
\end{tabular}

\begin{tabular}{|c|c|c|c|c|c|c|c|}
\hline \multirow{3}{*}{ Cone ID } & \multirow{3}{*}{ Cal Date } & \multirow{2}{*}{\multicolumn{2}{|c|}{$\mathrm{H}_{2} \mathrm{O}$}} & ConeVol & \multicolumn{3}{|c|}{$=$ Volume Read on Cone $(\mathrm{mL})$} \\
\hline & & & & Wt $\mathrm{H}_{2} \mathrm{O}$ Added & \multicolumn{3}{|c|}{$=\mathrm{Wt} \mathrm{H}_{2} \mathrm{O}$ Added to Cone $(\mathrm{g})$} \\
\hline & & $\mathrm{T}\left({ }^{\circ} \mathrm{C}\right)$ & $\mathrm{D}(\mathrm{g} / \mathrm{mL})$ & Vol $\mathrm{H}_{2} \mathrm{O}$ Added & \multicolumn{3}{|c|}{$=\mathrm{Wt} \mathrm{H}_{2} \mathrm{O}(\mathrm{g}) / \mathrm{D} \mathrm{H}_{2} \mathrm{O}(\mathrm{g} / \mathrm{mL})$} \\
\hline \multirow{6}{*}{$\begin{array}{c}\text { AW-106 } \\
\text { BLDN } \\
\text { Cone } 6\end{array}$} & \multirow{3}{*}{$11 / 16 / 12$} & \multirow{3}{*}{21.0} & \multirow{3}{*}{0.99799} & Cone Vol (mL) & 10.11 & 12.09 & 13.98 \\
\hline & & & & Wt $\mathrm{H}_{2} \mathrm{O}$ Added $(\mathrm{g})$ & 10.05515 & 12.01415 & 13.82372 \\
\hline & & & & $\mathrm{Vol} \mathrm{H}_{2} \mathrm{O}(\mathrm{mL})$ & 10.0754 & 12.0383 & 13.8515 \\
\hline & \multirow{3}{*}{$11 / 16 / 12$} & \multirow{3}{*}{21.0} & \multirow{3}{*}{0.9979} & Cone Vol $(\mathrm{mL})$ & 10.05 & 12.07 & 13.95 \\
\hline & & & & Wt $\mathrm{H}_{2} \mathrm{O}$ Added $(\mathrm{g})$ & 10.02131 & 11.99776 & 13.81385 \\
\hline & & & & $\mathrm{Vol} \mathrm{H}_{2} \mathrm{O}(\mathrm{mL})$ & 10.0415 & 12.0219 & 13.8416 \\
\hline \multicolumn{4}{|c|}{ Cone 6 - Sample CP } & \multicolumn{4}{|c|}{$\mathrm{Vol}_{\text {Corrected }}=\left(0.98 \times \mathrm{Vol}_{\text {Read }}\right)+0.23$} \\
\hline
\end{tabular}


LAB-RPT-13-00003 R0

Attachment A

Table A-1. Centrifuge Cone Volume Calibrations. (4 sheets)

\begin{tabular}{|c|c|c|c|c|c|c|c|}
\hline \multirow{3}{*}{ Cone ID } & \multirow{3}{*}{ Cal Date } & \multirow{2}{*}{\multicolumn{2}{|c|}{$\mathrm{H}_{2} \mathrm{O}$}} & ConeVol & \multicolumn{3}{|c|}{$=$ Volume Read on Cone $(\mathrm{mL})$} \\
\hline & & & & Wt $\mathrm{H}_{2} \mathrm{O}$ Added & \multicolumn{3}{|c|}{$=\mathrm{Wt} \mathrm{H}_{2} \mathrm{O}$ Added to Cone $(\mathrm{g})$} \\
\hline & & $\mathrm{T}\left({ }^{\circ} \mathrm{C}\right)$ & $\mathrm{D}(\mathrm{g} / \mathrm{mL})$ & Vol $\mathrm{H}_{2} \mathrm{O}$ Added & \multicolumn{3}{|c|}{$=\mathrm{Wt} \mathrm{H}_{2} \mathrm{O}(\mathrm{g}) / \mathrm{D} \mathrm{H}_{2} \mathrm{O}(\mathrm{g} / \mathrm{mL})$} \\
\hline \multirow{6}{*}{$\begin{array}{c}\text { AW-106 } \\
\text { BLDN } \\
\text { Cone } 8\end{array}$} & \multirow{3}{*}{$11 / 12 / 12$} & \multirow{3}{*}{21.5} & \multirow{3}{*}{0.99788} & Cone Vol $(\mathrm{mL})$ & 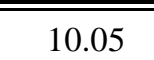 & 12.10 & 13.95 \\
\hline & & & & Wt $\mathrm{H}_{2} \mathrm{O}$ Added $(\mathrm{g})$ & 9.93728 & 11.93329 & 13.76967 \\
\hline & & & & $\mathrm{Vol} \mathrm{H}_{2} \mathrm{O}(\mathrm{mL})$ & 9.9584 & 11.9586 & 13.7986 \\
\hline & \multirow{3}{*}{$11 / 13 / 12$} & \multirow{3}{*}{20.6} & \multirow{3}{*}{0.99808} & Cone Vol (mL) & 10.09 & 12.06 & 14.00 \\
\hline & & & & Wt $\mathrm{H}_{2} \mathrm{O}$ Added $(\mathrm{g})$ & 9.97530 & 11.91983 & 13.80424 \\
\hline & & & & $\mathrm{Vol} \mathrm{H}_{2} \mathrm{O}(\mathrm{mL})$ & 9.9943 & 11.9428 & 13.8308 \\
\hline \multicolumn{4}{|c|}{ Cone 8 - Sample CON-1 } & \multicolumn{4}{|c|}{$\mathrm{Vol}_{\text {Corrected }}=\left(0.98 \times \mathrm{Vol}_{\text {Read }}\right)+0.08$} \\
\hline
\end{tabular}

\begin{tabular}{|c|c|c|c|c|c|c|c|}
\hline \multirow{3}{*}{ Cone ID } & \multirow{3}{*}{ Cal Date } & \multirow{2}{*}{\multicolumn{2}{|c|}{$\mathrm{H}_{2} \mathrm{O}$}} & \multirow{2}{*}{$\begin{array}{r}\text { ConeVol } \\
\mathrm{Wt} \mathrm{H}_{2} \mathrm{O} \text { Added }\end{array}$} & \multicolumn{3}{|c|}{$=$ Volume Read on Cone $(\mathrm{mL})$} \\
\hline & & & & & \multicolumn{3}{|c|}{$=\mathrm{Wt} \mathrm{H}_{2} \mathrm{O}$ Added to Cone $(\mathrm{g})$} \\
\hline & & $\mathrm{T}\left({ }^{\circ} \mathrm{C}\right)$ & $\mathrm{D}(\mathrm{g} / \mathrm{mL})$ & Vol $\mathrm{H}_{2} \mathrm{O}$ Added & \multicolumn{3}{|c|}{$=\mathrm{Wt} \mathrm{H}_{2} \mathrm{O}(\mathrm{g}) / \mathrm{D} \mathrm{H}_{2} \mathrm{O}(\mathrm{g} / \mathrm{mL})$} \\
\hline \multirow{6}{*}{$\begin{array}{c}\text { AW-106 } \\
\text { BLDN } \\
\text { Cone } 10\end{array}$} & \multirow{3}{*}{$11 / 12 / 12$} & \multirow{3}{*}{21.3} & \multirow{3}{*}{0.99793} & Cone Vol (mL) & 10.05 & 12.02 & 13.95 \\
\hline & & & & $\mathrm{Wt}_{2} \mathrm{O}$ Added $(\mathrm{g})$ & 10.00225 & 11.92800 & 13.77958 \\
\hline & & & & $\mathrm{Vol} \mathrm{H}_{2} \mathrm{O}(\mathrm{mL})$ & 10.0230 & 11.9528 & 13.8082 \\
\hline & \multirow{3}{*}{$11 / 13 / 12$} & \multirow{3}{*}{20.6} & \multirow{3}{*}{0.99808} & Cone Vol $(\mathrm{mL})$ & 10.09 & 12.05 & 13.95 \\
\hline & & & & Wt $\mathrm{H}_{2} \mathrm{O}$ Added $(\mathrm{g})$ & 10.02537 & 11.94759 & 13.83192 \\
\hline & & & & $\mathrm{Vol} \mathrm{H}{ }_{2} \mathrm{O}(\mathrm{mL})$ & 10.0447 & 11.9706 & 13.8586 \\
\hline \multicolumn{4}{|c|}{ Cone 10 - Sample DIL-2 } & \multicolumn{4}{|c|}{$\mathrm{Vol}_{\text {Corrected }}=\left(0.98 \times \mathrm{Vol}_{\text {Read }}\right)+0.17$} \\
\hline
\end{tabular}

\begin{tabular}{|c|c|c|c|c|c|c|c|}
\hline \multirow{3}{*}{ Cone ID } & \multirow{3}{*}{ Cal Date } & \multirow{2}{*}{\multicolumn{2}{|c|}{$\mathrm{H}_{2} \mathrm{O}$}} & ConeVol & \multicolumn{3}{|c|}{$=$ Volume Read on Cone $(\mathrm{mL})$} \\
\hline & & & & Wt $\mathrm{H}_{2} \mathrm{O}$ Added & \multicolumn{3}{|c|}{$=\mathrm{Wt} \mathrm{H}_{2} \mathrm{O}$ Added to Cone $(\mathrm{g})$} \\
\hline & & $\mathrm{T}\left({ }^{\circ} \mathrm{C}\right)$ & $\mathrm{D}(\mathrm{g} / \mathrm{mL})$ & Vol $\mathrm{H}_{2} \mathrm{O}$ Added & \multicolumn{3}{|c|}{$=\mathrm{Wt} \mathrm{H}_{2} \mathrm{O}(\mathrm{g}) / \mathrm{D} \mathrm{H}_{2} \mathrm{O}(\mathrm{g} / \mathrm{mL})$} \\
\hline \multirow{6}{*}{$\begin{array}{c}\text { AW-106 } \\
\text { BLDN } \\
\text { Cone } 11\end{array}$} & \multirow{3}{*}{$11 / 12 / 12$} & \multirow{3}{*}{21.3} & \multirow{3}{*}{0.99793} & Cone Vol (mL) & 10.05 & 12.05 & 14.00 \\
\hline & & & & Wt $\mathrm{H}_{2} \mathrm{O}$ Added $(\mathrm{g})$ & 9.98536 & 11.96007 & 13.85431 \\
\hline & & & & $\mathrm{Vol} \mathrm{H}_{2} \mathrm{O}(\mathrm{mL})$ & 10.0061 & 11.9849 & 13.8831 \\
\hline & \multirow{3}{*}{$11 / 13 / 12$} & \multirow{3}{*}{20.6} & \multirow{3}{*}{0.99808} & Cone Vol $(\mathrm{mL})$ & 10.07 & 12.07 & 13.95 \\
\hline & & & & Wt $\mathrm{H}_{2} \mathrm{O}$ Added $(\mathrm{g})$ & 10.06973 & 11.97845 & 13.82213 \\
\hline & & & & $\mathrm{Vol} \mathrm{H}_{2} \mathrm{O}(\mathrm{mL})$ & 10.0891 & 12.0015 & 13.8487 \\
\hline \multicolumn{4}{|c|}{ Cone 11 - Sample CON-2 } & \multicolumn{4}{|c|}{$\mathrm{Vol}_{\text {Corrected }}=\left(0.98 \times \mathrm{Vol}_{\text {Read }}\right)+0.23$} \\
\hline
\end{tabular}


LAB-RPT-13-00003 R0 Attachment A

Table A-1. Centrifuge Cone Volume Calibrations. (4 sheets)

\begin{tabular}{|c|c|c|c|c|c|c|c|}
\hline \multirow{3}{*}{ Cone ID } & \multirow{3}{*}{ Cal Date } & \multirow{2}{*}{\multicolumn{2}{|c|}{$\mathrm{H}_{2} \mathrm{O}$}} & \multicolumn{4}{|c|}{$=$ Volume Read on Cone $(\mathrm{mL})$} \\
\hline & & & & $\mathrm{Wt} \mathrm{H}_{2} \mathrm{O}$ Added & \multicolumn{3}{|c|}{$=\mathrm{Wt} \mathrm{H}_{2} \mathrm{O}$ Added to Cone $(\mathrm{g})$} \\
\hline & & $\mathrm{T}\left({ }^{\circ} \mathrm{C}\right)$ & $\mathrm{D}(\mathrm{g} / \mathrm{mL})$ & Vol $\mathrm{H}_{2} \mathrm{O}$ Added & \multicolumn{3}{|c|}{$=\mathrm{Wt} \mathrm{H}_{2} \mathrm{O}(\mathrm{g}) / \mathrm{D} \mathrm{H}_{2} \mathrm{O}(\mathrm{g} / \mathrm{mL})$} \\
\hline \multirow{6}{*}{$\begin{array}{c}\text { AW-106 } \\
\text { BLDN } \\
\text { Cone } 13\end{array}$} & \multirow{3}{*}{$11 / 12 / 12$} & \multirow{3}{*}{21.2} & \multirow{3}{*}{0.99795} & Cone Vol $(\mathrm{mL})$ & 10.07 & 12.03 & 14.00 \\
\hline & & & & Wt $\mathrm{H}_{2} \mathrm{O}$ Added $(\mathrm{g})$ & 10.00435 & 11.91339 & 13.84452 \\
\hline & & & & $\mathrm{Vol} \mathrm{H}_{2} \mathrm{O}(\mathrm{mL})$ & 10.0249 & 11.9379 & 13.8730 \\
\hline & \multirow{3}{*}{$11 / 13 / 12$} & \multirow{3}{*}{20.7} & \multirow{3}{*}{0.99806} & Cone Vol $(\mathrm{mL})$ & 10.05 & 12.05 & 13.98 \\
\hline & & & & Wt $\mathrm{H}_{2} \mathrm{O}$ Added $(\mathrm{g})$ & 9.97052 & 11.95501 & 13.82254 \\
\hline & & & & $\mathrm{Vol} \mathrm{H}_{2} \mathrm{O}(\mathrm{mL})$ & 9.9899 & 11.9783 & 13.8494 \\
\hline \multicolumn{4}{|c|}{ Cone 13 - Sample CON-7 } & \multicolumn{4}{|c|}{$\operatorname{Vol}_{\text {Corrected }}=\left(0.98 \times \mathrm{Vol}_{\text {Read }}\right)+0.15$} \\
\hline
\end{tabular}

\begin{tabular}{|c|c|c|c|c|c|c|c|}
\hline \multirow{3}{*}{ Cone ID } & \multirow{3}{*}{ Cal Date } & \multirow{2}{*}{\multicolumn{2}{|c|}{$\mathrm{H}_{2} \mathrm{O}$}} & ConeVol & \multicolumn{3}{|c|}{$=$ Volume Read on Cone $(\mathrm{mL})$} \\
\hline & & & & Wt $\mathrm{H}_{2} \mathrm{O}$ Added & \multicolumn{3}{|c|}{$=\mathrm{Wt} \mathrm{H}_{2} \mathrm{O}$ Added to Cone $(\mathrm{g})$} \\
\hline & & $\mathrm{T}\left({ }^{\circ} \mathrm{C}\right)$ & $\mathrm{D}(\mathrm{g} / \mathrm{mL})$ & Vol $\mathrm{H}_{2} \mathrm{O}$ Added & \multicolumn{3}{|c|}{$=\mathrm{Wt} \mathrm{H}_{2} \mathrm{O}(\mathrm{g}) / \mathrm{D} \mathrm{H}_{2} \mathrm{O}(\mathrm{g} / \mathrm{mL})$} \\
\hline \multirow{6}{*}{$\begin{array}{c}\text { AW-106 } \\
\text { BLDN } \\
\text { Cone } 14\end{array}$} & \multirow{3}{*}{$11 / 12 / 12$} & \multirow{3}{*}{21.1} & \multirow{3}{*}{0.99797} & Cone Vol $(\mathrm{mL})$ & 10.02 & 12.10 & 13.95 \\
\hline & & & & Wt $\mathrm{H}_{2} \mathrm{O}$ Added $(\mathrm{g})$ & 9.96208 & 11.97237 & 13.81411 \\
\hline & & & & $\mathrm{Vol} \mathrm{H}_{2} \mathrm{O}(\mathrm{mL})$ & 9.9823 & 11.9967 & 13.8422 \\
\hline & \multirow{3}{*}{$11 / 13 / 12$} & \multirow{3}{*}{20.7} & \multirow{3}{*}{0.99806} & Cone Vol (mL) & 10.09 & 11.95 & 13.95 \\
\hline & & & & $\mathrm{Wt}_{2} \mathrm{O}$ Added $(\mathrm{g})$ & 10.03283 & 11.85613 & 13.81576 \\
\hline & & & & $\mathrm{Vol} \mathrm{H}_{2} \mathrm{O}(\mathrm{mL})$ & 10.0524 & 11.8792 & 13.8427 \\
\hline \multicolumn{4}{|c|}{ Cone 14 - Sample CON-6 } & \multicolumn{4}{|c|}{$\mathrm{Vol}_{\text {Corrected }}=\left(0.98 \times \mathrm{Vol}_{\text {Read }}\right)+0.14$} \\
\hline
\end{tabular}

\begin{tabular}{|c|c|c|c|c|c|c|c|}
\hline \multirow{3}{*}{ Cone ID } & \multirow{3}{*}{ Cal Date } & \multirow{2}{*}{\multicolumn{2}{|c|}{$\mathrm{H}_{2} \mathrm{O}$}} & ConeVol & \multicolumn{3}{|c|}{$=$ Volume Read on Cone $(\mathrm{mL})$} \\
\hline & & & & Wt $\mathrm{H}_{2} \mathrm{O}$ Added & \multicolumn{3}{|c|}{$=\mathrm{Wt} \mathrm{H}_{2} \mathrm{O}$ Added to Cone $(\mathrm{g})$} \\
\hline & & $\mathrm{T}\left({ }^{\circ} \mathrm{C}\right)$ & $\mathrm{D}(\mathrm{g} / \mathrm{mL})$ & Vol $\mathrm{H}_{2} \mathrm{O}$ Added & \multicolumn{3}{|c|}{$=\mathrm{Wt} \mathrm{H}_{2} \mathrm{O}(\mathrm{g}) / \mathrm{D} \mathrm{H}_{2} \mathrm{O}(\mathrm{g} / \mathrm{mL})$} \\
\hline \multirow{6}{*}{$\begin{array}{c}\text { AW-106 } \\
\text { BLDN } \\
\text { Cone } 15\end{array}$} & \multirow{3}{*}{$11 / 16 / 12$} & \multirow{3}{*}{21.0} & \multirow{3}{*}{0.99799} & Cone Vol (mL) & 10.09 & 12.02 & 14.02 \\
\hline & & & & Wt $\mathrm{H}_{2} \mathrm{O}$ Added $(\mathrm{g})$ & 10.09085 & 12.03928 & 13.94215 \\
\hline & & & & $\mathrm{Vol} \mathrm{H}_{2} \mathrm{O}(\mathrm{mL})$ & 10.1112 & 12.0635 & 13.9702 \\
\hline & \multirow{3}{*}{$11 / 16 / 12$} & \multirow{3}{*}{20.9} & \multirow{3}{*}{0.99801} & Cone Vol $(\mathrm{mL})$ & 10.04 & 12.05 & 14.02 \\
\hline & & & & $\mathrm{Wt}_{2} \mathrm{O}$ Added (g) & 10.06847 & 12.04975 & 13.95205 \\
\hline & & & & $\mathrm{Vol} \mathrm{H}_{2} \mathrm{O}(\mathrm{mL})$ & 10.0887 & 12.0737 & 13.9798 \\
\hline \multicolumn{4}{|c|}{ Cone 15 - Sample DIL-1 } & \multicolumn{4}{|c|}{$\mathrm{Vol}_{\text {Corrected }}=\left(0.98 \times \mathrm{Vol}_{\text {Read }}\right)+0.25$} \\
\hline
\end{tabular}


LAB-RPT-13-00003 R0

\section{ATTACHMENT B}

BOILDOWN HOT CELL DATA LOGS 
LAB-RPT-13-00003 R0

Attachment B

\section{BOILDOWN HOT CELL DATA LOG}

The hot cell data log reproduced in Table B-1 was used to track the progress of the boildown operations and to calculate volumes of water $\left(\Delta \mathrm{H}_{2} \mathrm{O}\right)$ that needed to be distilled from or added to the test sample to reach target concentrations or densities. Quantities of water removed from or added to the boildown pot were weighed and then converted to volumes by dividing by the density of pure water at $27.1{ }^{\circ} \mathrm{C}$. The volumes of samples removed from the pot were calculated by dividing the weight of the samples by the model density $\left(\mathrm{D}_{\text {Model }}{ }^{27 .{ }^{\circ} \mathrm{C}}\right)$ calculated by the spreadsheet.

A registered and verified Excel spreadsheet (SVF-1543; SDD RPP-38843) was used to generate the hot cell data log. Within the log, the chronology of entries proceeds from left to right across a row, and then down to the following row.

The primary hot cell data log was subsequently modified by changing the base reference temperature for the model calculations from $27.1^{\circ} \mathrm{C}$ to $18.0^{\circ} \mathrm{C}$. This revised data $\log$ is presented in Table B-2.

The column headings/entries in the data logs are defined as follows:

\begin{tabular}{|c|c|}
\hline \multirow[t]{2}{*}{ Sample Rmvd (mL) } & $\begin{array}{l}\text { Volume of sample withdrawn from pot at beginning of step as } \\
\text { read from volume gradations on centrifuge cone }\end{array}$ \\
\hline & $=$ Manual data entry \\
\hline \multirow[t]{2}{*}{ Pot Vol Initial (mL) } & $\begin{array}{l}\text { Volume of pot contents after removal of a sample following the } \\
\text { conclusion of a preceding concentration/dilution step }\end{array}$ \\
\hline & $=(\text { Pot Vol Final })_{\text {previous }}-(\text { Sample Vol Corrected })_{\text {current }}$ \\
\hline \multirow[t]{2}{*}{$\Delta \mathrm{H}_{2} \mathrm{O}(\mathrm{mL})$} & $\begin{array}{l}\text { Volume of water removed from or added to pot contents during a } \\
\text { concentration/dilution step read from a graduated cylinder }\end{array}$ \\
\hline & $=$ Manual data entry with additions entered as negative values \\
\hline \multirow[t]{2}{*}{ Pot Vol Final (mL) } & Final volume of pot contents for a step \\
\hline & $=(\text { Pot Vol Initial })_{\text {current }}-\left(\Delta \mathrm{H}_{2} \mathrm{O}\right)_{\text {current }}$ \\
\hline \multirow[t]{2}{*}{$C R$ Step } & (Incremental) concentration ratio for a step \\
\hline & $=(\text { Pot Vol Initial })_{\text {current }} \div(\text { Pot Vol Final })_{\text {current }}$ \\
\hline \multirow[t]{2}{*}{$C R$ Total } & $\begin{array}{l}\text { (Cumulative) concentration ratio applicable to a boildown since } \\
\text { the last baseline reset }\end{array}$ \\
\hline & $=(C R \text { Total })_{\text {previous }} \times(C R \text { Step })_{\text {current }}$ \\
\hline
\end{tabular}


LAB-RPT-13-00003 R0

Attachment B

\begin{tabular}{|c|c|}
\hline \multirow[t]{2}{*}{$\% \mathrm{WVR}$} & $\begin{array}{l}\% \text { waste volume reduction applicable to a boildown since the last } \\
\text { baseline reset }\end{array}$ \\
\hline & $=\left\{\left[(\mathrm{CR} \text { Total })_{\text {current }}-1.0\right] \div(C R \text { Total })_{\text {current }}\right\} \times 100$ \\
\hline \multirow[t]{2}{*}{$\mathrm{D}_{\text {Model }}(\mathrm{g} / \mathrm{mL})$} & $\begin{array}{l}\text { Calculated density of pot contents, based on simple additive } \\
\text { additions model, at the end of a boildown step }\end{array}$ \\
\hline & $=\left[\left(\mathrm{D}_{\text {Initial Composite }}-\mathrm{D}_{\mathrm{H} 2 \mathrm{O}}\right) \times C R\right.$ Total $]+\mathrm{D}_{\mathrm{H} 2 \mathrm{O}}$ \\
\hline \multirow[t]{2}{*}{$\mathrm{P}_{\text {Read }}($ Torr) } & $\begin{array}{l}\text { Pressure in the boildown apparatus read from pressure } \\
\text { reader/controller }\end{array}$ \\
\hline & $=$ Manual data entry \\
\hline \multirow[t]{2}{*}{$\mathrm{P}_{\text {Corr }}$ (Torr) } & Corrected pressure in boildown apparatus \\
\hline & $=(1.01)\left(\mathrm{P}_{\text {Read }}\right)+3.50$ \\
\hline \multirow[t]{2}{*}{$\mathrm{T}_{\text {Read }}\left({ }^{\circ} \mathrm{C}\right)$} & $\begin{array}{l}\text { Temperature of pot contents from readout of K-type } \\
\text { thermocouple/reader }\end{array}$ \\
\hline & $=$ Manual data entry \\
\hline \multirow[t]{2}{*}{$\mathrm{T}_{\text {Corr }}\left({ }^{\circ} \mathrm{C}\right)$} & Corrected temperature of pot contents \\
\hline & $=\left(2.81 \times 10^{-6}\right)\left(\mathrm{T}_{\text {Read }}\right)^{3}-\left(7.16 \times 10^{-4}\right)\left(\mathrm{T}_{\text {Read }}\right)^{2}+(1.04)\left(\mathrm{T}_{\text {Read }}\right)+1.20$ \\
\hline
\end{tabular}

The abbreviations used in the row entries in the 'Action' column are defined as follows:

\begin{tabular}{|l|l|}
\hline CON-\# & Boildown volume reduction step \# and sample \# \\
\hline DIL-\# & Boildown dilution step \# and sample \# \\
\hline P/T Step \# [ $\left.\mathrm{P}_{\text {nominal }}\right]$ & $\begin{array}{l}\text { Measurement of boiling temperature }(\mathrm{T}) \text { and system pressure (P) } \\
\text { during specified boildown/dilution step (\#) at nominal test } \\
\text { pressure of 40,60, or 80 Torr }\end{array}$ \\
\hline
\end{tabular}


Table B-1. Tank 241-AW-106 Boildown Hot Cell Data Log. (3 sheets)

Vol Initial Composite $(\mathrm{mL})=618.199 \mathrm{~g} / 1.2659 \mathrm{~g} / \mathrm{mL}$

$\Delta \mathrm{H}_{2} \mathrm{O}(\mathrm{mL})=\mathrm{Wt} \mathrm{H}_{2} \mathrm{O} / \mathrm{D}_{\mathrm{H} 2 \mathrm{O}}$ at $27.1^{\circ} \mathrm{C}$

Sample Rmvd $(\mathrm{mL})=\mathrm{Wt}$ Sample $/ \mathrm{D}_{\text {Model }}{ }^{27.1^{\circ} \mathrm{C}}$

\begin{tabular}{|c|c|c|c|c|c|c|c|c|c|c|c|c|c|c|}
\hline & & & & & & & & & $\rho \mathrm{H}_{2} \mathrm{O}$ & 0.99649 & & & & \\
\hline & & Action & & & $\Delta \mathrm{H}_{2} \mathrm{O}$ & & $\mathrm{CR}$ & $\mathrm{CR}$ & \%WVR & $\rho$ & $\mathrm{P}$ & & $\mathrm{T}$ & $\mathrm{T}$ \\
\hline $\begin{array}{c}\text { Date } \\
\mathrm{mm} / \mathrm{dd}\end{array}$ & $\begin{array}{c}\text { Time } \\
\text { hh:mm }\end{array}$ & & $\begin{array}{l}\text { Rmvd } \\
(\mathrm{mL})\end{array}$ & $\begin{array}{l}\text { Initial } \\
(\mathrm{mL})\end{array}$ & $(\mathrm{mL})$ & $\begin{array}{l}\text { Final } \\
(\mathrm{mL})\end{array}$ & Step & Total & & $\begin{array}{c}\text { Calc } \\
(\mathrm{g} / \mathrm{mL})\end{array}$ & $\begin{array}{l}\text { Read } \\
\text { (torr) }\end{array}$ & $\begin{array}{l}\text { Calc } \\
\text { (torr) }\end{array}$ & $\begin{array}{c}\text { Read } \\
\left({ }^{\circ} \mathrm{C}\right)\end{array}$ & $\begin{array}{l}\text { Calc } \\
\left({ }^{\circ} \mathrm{C}\right)\end{array}$ \\
\hline $02 / 20$ & 09:30 & INITIAL & 0.00 & 488.309 & 0.000 & 488.309 & 1.0000 & 1.0000 & 0.000 & 1.2659 & - & - & - & - \\
\hline & $10: 40$ & $\mathrm{P} / \mathrm{T} 0$ [40] & 0.00 & 488.309 & 0.000 & 488.309 & 1.0000 & 1.0000 & 0.000 & 1.2659 & 37 & 40.9 & 37.5 & 38.11 \\
\hline & $10: 55$ & P/T 0 [60] & 0.00 & 488.309 & 0.000 & 488.309 & 1.0000 & 1.0000 & 0.000 & 1.2659 & 57 & 61.1 & 45.5 & 46.04 \\
\hline & 11:00 & P/T 0 [80] & 0.00 & 488.309 & 0.000 & 488.309 & 1.0000 & 1.0000 & 0.000 & 1.2659 & 76 & 80.3 & 51.4 & 51.86 \\
\hline & $11: 10$ & CON 1a & 0.00 & 488.309 & 37.382 & 450.927 & 1.0829 & 1.0829 & 7.655 & 1.2882 & - & - & - & - \\
\hline & $12: 34$ & $\mathrm{P} / \mathrm{T}$ 1a [40] & 0.00 & 450.927 & 0.000 & 450.927 & 1.0000 & 1.0829 & 7.655 & 1.2882 & 36 & 39.9 & 37.9 & 38.51 \\
\hline & $12: 43$ & $\mathrm{P} / \mathrm{T}$ 1a [60] & 0.00 & 450.927 & 0.000 & 450.927 & 1.0000 & 1.0829 & 7.655 & 1.2882 & 57 & 61.1 & 46.2 & 46.73 \\
\hline & $12: 50$ & $\mathrm{P} / \mathrm{T}$ 1a [80] & 0.00 & 450.927 & 0.000 & 450.927 & 1.0000 & 1.0829 & 7.655 & 1.2882 & 76 & 80.3 & 51.7 & 52.16 \\
\hline & 13:02 & $\mathrm{CON} 1 \mathrm{~b}$ & 0.00 & 450.927 & 39.406 & 411.521 & 1.0958 & 1.1866 & 15.725 & 1.3162 & - & - & - & - \\
\hline & $13: 49$ & $\mathrm{P} / \mathrm{T} 1 \mathrm{~b}[40]$ & 0.00 & 411.521 & 0.000 & 411.521 & 1.0000 & 1.1866 & 15.725 & 1.3162 & 35 & 38.9 & 38.3 & 38.86 \\
\hline & $13: 58$ & $\mathrm{P} / \mathrm{T} 1 \mathrm{~b}[60]$ & 0.00 & 411.521 & 0.000 & 411.521 & 1.0000 & 1.1866 & 15.725 & 1.3162 & 57 & 61.1 & 46.8 & 47.32 \\
\hline & $14: 04$ & $\mathrm{P} / \mathrm{T} 1 \mathrm{~b}[80]$ & 0.00 & 411.521 & 0.000 & 411.521 & 1.0000 & 1.1866 & 15.725 & 1.3162 & 77 & 81.3 & 52.7 & 53.14 \\
\hline & & EON 1e & 0.00 & 411.521 & 0.000 & 411.521 & 1.0000 & 1.1866 & 15.725 & 1.3162 & - & - & - & - \\
\hline & & $\mathrm{P} / \mathrm{T} 1 \mathrm{c}[40]$ & 0.00 & 411.521 & 0.000 & 411.521 & 1.0000 & 1.1866 & 15.725 & 1.3162 & - & - & - & - \\
\hline & & $\mathrm{P} / \mathrm{T} 1 \mathrm{c}[60]$ & 0.00 & 411.521 & 0.000 & 411.521 & 1.0000 & 1.1866 & 15.725 & 1.3162 & - & - & - & - \\
\hline & & $\mathrm{P} / \mathrm{T}$ 1c $[80]$ & 0.00 & 411.521 & 0.000 & 411.521 & 1.0000 & 1.1866 & 15.725 & 1.3162 & - & - & - & - \\
\hline & $14: 20$ & Sample Con-1 & 12.51 & 399.011 & 0.000 & 399.011 & 1.0000 & 1.1866 & 15.725 & 1.3162 & - & - & - & - \\
\hline
\end{tabular}


Table B-1. Tank 241-AW-106 Boildown Hot Cell Data Log. (3 sheets)

\begin{tabular}{|c|c|c|c|c|c|c|c|c|c|c|c|c|c|c|}
\hline \multirow{2}{*}{\multicolumn{2}{|c|}{2013}} & \multirow{3}{*}{ Action } & \multirow{3}{*}{$\begin{array}{l}\text { Sample } \\
\text { Rmvd } \\
(\mathrm{mL})\end{array}$} & \multirow{3}{*}{$\begin{array}{c}\text { Pot Vol } \\
\text { Initial } \\
(\mathrm{mL})\end{array}$} & \multirow{3}{*}{$\begin{array}{c}\Delta \mathrm{H}_{2} \mathrm{O} \\
(\mathrm{mL})\end{array}$} & \multirow{3}{*}{$\begin{array}{c}\text { Pot Vol } \\
\text { Final } \\
(\mathrm{mL})\end{array}$} & & & $\rho \mathrm{H}_{2} \mathrm{O}$ & 0.99649 & & & & \\
\hline & & & & & & & \multirow{2}{*}{$\begin{array}{c}\text { CR } \\
\text { Step }\end{array}$} & \multirow{2}{*}{$\begin{array}{c}\text { CR } \\
\text { Total }\end{array}$} & \multirow[t]{2}{*}{$\% \mathrm{WVR}$} & \multirow{2}{*}{$\begin{array}{c}\rho \\
\text { Calc } \\
(\mathrm{g} / \mathrm{mL})\end{array}$} & \multirow{2}{*}{$\begin{array}{c}\mathrm{P} \\
\text { Read } \\
\text { (torr) }\end{array}$} & \multirow{2}{*}{$\begin{array}{c}\mathrm{P} \\
\text { Calc } \\
\text { (torr) }\end{array}$} & \multirow{2}{*}{$\begin{array}{c}\mathrm{T} \\
\text { Read } \\
\left({ }^{\circ} \mathrm{C}\right)\end{array}$} & \multirow{2}{*}{$\begin{array}{c}\mathrm{T} \\
\text { Calc } \\
\left({ }^{\circ} \mathrm{C}\right)\end{array}$} \\
\hline $\begin{array}{c}\text { Date } \\
\mathrm{mm} / \mathrm{dd}\end{array}$ & $\begin{array}{c}\text { Time } \\
\text { hh:mm }\end{array}$ & & & & & & & & & & & & & \\
\hline \multirow[t]{20}{*}{$02 / 21$} & $07: 56$ & $\mathrm{CON} 2$ & 0.00 & 399.011 & 37.694 & 361.317 & 1.1043 & 1.3104 & 23.687 & 1.3495 & - & - & - & - \\
\hline & $08: 27$ & P/T 2 [80] & 0.00 & 361.317 & 0.000 & 361.317 & 1.0000 & 1.3104 & 23.687 & 1.3495 & 36 & 39.9 & 39.2 & 39.75 \\
\hline & $08: 33$ & P/T 2 [60] & 0.00 & 361.317 & 0.000 & 361.317 & 1.0000 & 1.3104 & 23.687 & 1.3495 & 56 & 60.1 & 47.3 & 47.82 \\
\hline & $08: 39$ & $\mathrm{P} / \mathrm{T} 2$ [40] & 0.00 & 361.317 & 0.000 & 361.317 & 1.0000 & 1.3104 & 23.687 & 1.3495 & 76 & 80.3 & 53.2 & 53.58 \\
\hline & $08: 55$ & Sample Con-2 & 12.49 & 348.827 & 0.000 & 348.827 & 1.0000 & 1.3104 & 23.687 & 1.3495 & - & - & - & - \\
\hline & 09:12 & CON 3 & 0.00 & 348.827 & 26.710 & 322.117 & 1.0829 & 1.4190 & 29.530 & 1.3788 & - & - & - & - \\
\hline & 10:04 & P/T 3 [40] & 0.00 & 322.117 & 0.000 & 322.117 & 1.0000 & 1.4190 & 29.530 & 1.3788 & 36 & 39.9 & 40.0 & 40.59 \\
\hline & 10:11 & P/T 3 [60] & 0.00 & 322.117 & 0.000 & 322.117 & 1.0000 & 1.4190 & 29.530 & 1.3788 & 57 & 61.1 & 48.5 & 48.95 \\
\hline & $10: 15$ & P/T 3 [80] & 0.00 & 322.117 & 0.000 & 322.117 & 1.0000 & 1.4190 & 29.530 & 1.3788 & 77 & 81.3 & 54.3 & 54.71 \\
\hline & $10: 27$ & Sample Con-3 & 12.48 & 309.637 & 0.000 & 309.637 & 1.0000 & 1.4190 & 29.530 & 1.3788 & - & - & - & - \\
\hline & $10: 45$ & $\mathrm{CON} 4$ & 0.00 & 309.637 & 25.450 & 284.187 & 1.0896 & 1.5461 & 35.322 & 1.4130 & - & - & - & - \\
\hline & $11: 17$ & $\mathrm{P} / \mathrm{T} 4$ [40] & 0.00 & 284.187 & 0.000 & 284.187 & 1.0000 & 1.5461 & 35.322 & 1.4130 & 37 & 40.9 & 41.3 & 41.88 \\
\hline & $11: 21$ & $\mathrm{P} / \mathrm{T} 4[60]$ & 0.00 & 284.187 & 0.000 & 284.187 & 1.0000 & 1.5461 & 35.322 & 1.4130 & 56 & 60.1 & 49.1 & 49.59 \\
\hline & $11: 24$ & $\mathrm{P} / \mathrm{T} 4[80]$ & 0.00 & 284.187 & 0.000 & 284.187 & 1.0000 & 1.5461 & 35.322 & 1.4130 & 76 & 80.3 & 55.1 & 55.45 \\
\hline & $11: 39$ & Sample Con-4 & 12.42 & 271.767 & 0.000 & 271.767 & 1.0000 & 1.5461 & 35.322 & 1.4130 & - & - & - & - \\
\hline & $11: 54$ & CON 5 & 0.00 & 271.767 & 21.434 & 250.333 & 1.0856 & 1.6785 & 40.423 & 1.4487 & - & - & - & - \\
\hline & $12: 38$ & P/T 5 [40] & 0.00 & 250.333 & 0.000 & 250.333 & 1.0000 & 1.6785 & 40.423 & 1.4487 & 36 & 39.9 & 41.8 & 42.38 \\
\hline & & P/T 5 [60] & 0.00 & 250.333 & 0.000 & 250.333 & 1.0000 & 1.6785 & 40.423 & 1.4487 & 57 & 61.1 & 50.3 & 50.78 \\
\hline & & P/T 5 [80] & 0.00 & 250.333 & 0.000 & 250.333 & 1.0000 & 1.6785 & 40.423 & 1.4487 & 76 & 80.3 & 56.0 & 56.38 \\
\hline & $12: 48$ & Sample Con-5 & 12.34 & 237.993 & 0.000 & 237.993 & 1.0000 & 1.6785 & 40.423 & 1.4487 & - & - & - & - \\
\hline
\end{tabular}


Table B-1. Tank 241-AW-106 Boildown Hot Cell Data Log. (3 sheets)

\begin{tabular}{|c|c|c|c|c|c|c|c|c|c|c|c|c|c|c|}
\hline \multirow{2}{*}{\multicolumn{2}{|c|}{2013}} & \multirow{3}{*}{ Action } & \multirow{3}{*}{$\begin{array}{c}\text { Sample } \\
\text { Rmvd } \\
(\mathrm{mL})\end{array}$} & \multirow{3}{*}{$\begin{array}{c}\text { Pot Vol } \\
\text { Initial } \\
(\mathrm{mL})\end{array}$} & \multirow{3}{*}{$\begin{array}{r}\Delta \mathrm{H}_{2} \mathrm{O} \\
(\mathrm{mL})\end{array}$} & \multirow{3}{*}{$\begin{array}{c}\text { Pot Vol } \\
\text { Final } \\
(\mathrm{mL})\end{array}$} & \multirow{3}{*}{$\begin{array}{c}\text { CR } \\
\text { Step }\end{array}$} & & \multirow{3}{*}{$\frac{\rho \mathrm{H}_{2} \mathrm{O}}{\% \mathrm{WVR}}$} & \multirow{3}{*}{$\begin{array}{c}0.99649 \\
\rho \\
\text { Calc } \\
(\mathrm{g} / \mathrm{mL}) \\
\end{array}$} & \multirow{3}{*}{$\begin{array}{c}\mathrm{P} \\
\text { Read } \\
\text { (torr) }\end{array}$} & \multirow{3}{*}{$\begin{array}{c}\mathrm{P} \\
\text { Calc } \\
\text { (torr) }\end{array}$} & \multirow{3}{*}{$\begin{array}{c}\mathrm{T} \\
\text { Read } \\
\left({ }^{\circ} \mathrm{C}\right) \\
\end{array}$} & \multirow{3}{*}{$\begin{array}{c}\mathrm{T} \\
\text { Calc } \\
\left({ }^{\circ} \mathrm{C}\right) \\
\end{array}$} \\
\hline & & & & & & & & \multirow{2}{*}{$\begin{array}{c}\text { CR } \\
\text { Total }\end{array}$} & & & & & & \\
\hline \multirow[t]{20}{*}{$\begin{array}{c}\text { Date } \\
\mathrm{mm} / \mathrm{dd}\end{array}$} & $\begin{array}{c}\text { Time } \\
\text { hh:mm }\end{array}$ & & & & & & & & & & & & & \\
\hline & $13: 04$ & CON 6 & 0.00 & 237.993 & 19.504 & 218.489 & 1.0893 & 1.8283 & 45.306 & 1.4891 & - & - & - & - \\
\hline & $13: 18$ & P/T 6 [40] & 0.00 & 218.489 & 0.000 & 218.489 & 1.0000 & 1.8283 & 45.306 & 1.4891 & 36 & 39.9 & 43.0 & 43.52 \\
\hline & $13: 22$ & P/T 6 [60] & 0.00 & 218.489 & 0.000 & 218.489 & 1.0000 & 1.8283 & 45.306 & 1.4891 & 56 & 60.1 & 51.2 & 51.66 \\
\hline & $13: 25$ & P/T 6 [80] & 0.00 & 218.489 & 0.000 & 218.489 & 1.0000 & 1.8283 & 45.306 & 1.4891 & 78 & 82.3 & 57.5 & 57.86 \\
\hline & $13: 37$ & Sample Con-6 & 12.40 & 206.089 & 0.000 & 206.089 & 1.0000 & 1.8283 & 45.306 & 1.4891 & - & - & - & - \\
\hline & $13: 57$ & CON 7 & 0.00 & 206.089 & 18.077 & 188.012 & 1.0961 & 2.0041 & 50.103 & 1.5364 & - & - & - & - \\
\hline & 14:09 & P/T 7 [80] & 0.00 & 188.012 & 0.000 & 188.012 & 1.0000 & 2.0041 & 50.103 & 1.5364 & 76 & 80.3 & 57.6 & 57.95 \\
\hline & $14: 10$ & P/T 7 [60] & 0.00 & 188.012 & 0.000 & 188.012 & 1.0000 & 2.0041 & 50.103 & 1.5364 & 56 & 60.1 & 51.2 & 51.66 \\
\hline & $14: 13$ & $\mathrm{P} / \mathrm{T} 7$ [40] & 0.00 & 188.012 & 0.000 & 188.012 & 1.0000 & 2.0041 & 50.103 & 1.5364 & 37 & 40.9 & 43.7 & 44.26 \\
\hline & $14: 24$ & Sample Con-7 & 12.37 & 175.642 & 0.000 & 175.642 & 1.0000 & 2.0041 & 50.103 & 1.5364 & - & - & - & - \\
\hline & $14: 50$ & DIL 1 & 0.00 & 175.642 & -52.803 & 228.445 & 0.7689 & 1.5409 & 35.103 & 1.4116 & - & - & - & - \\
\hline & $15: 00$ & $\mathrm{P} / \mathrm{T} 10$ [60] & 0.00 & 228.445 & 0.000 & 228.445 & 1.0000 & 1.5409 & 35.103 & 1.4116 & 57 & 61.1 & 49.0 & 49.50 \\
\hline & $15: 08$ & Sample Dil-1 & 12.31 & 216.135 & 0.000 & 216.135 & 1.0000 & 1.5409 & 35.103 & 1.4116 & - & - & - & - \\
\hline & $15: 26$ & DIL 2 & 0.00 & 216.135 & -35.347 & 251.482 & 0.8594 & 1.3243 & 24.489 & 1.3533 & - & - & - & - \\
\hline & $15: 38$ & $\mathrm{P} / \mathrm{T} 11[60]$ & 0.00 & 251.482 & 0.000 & 251.482 & 1.0000 & 1.3243 & 24.489 & 1.3533 & 57 & 61.1 & 47.6 & 48.11 \\
\hline & $16: 00$ & Sample Dil-2 & 12.53 & 238.952 & 0.000 & 238.952 & 1.0000 & 1.3243 & 24.489 & 1.3533 & - & - & - & - \\
\hline & $16: 10$ & DIL 3 & 0.00 & 238.952 & -46.759 & 285.711 & 0.8363 & 1.1076 & 9.713 & 1.2949 & - & - & - & - \\
\hline & $16: 23$ & P/T 12 [60] & 0.00 & 285.711 & 0.000 & 285.711 & 1.0000 & 1.1076 & 9.713 & 1.2949 & 57 & 61.1 & 46.3 & 46.83 \\
\hline & $16: 33$ & Sample Dil-3 & 12.60 & 273.111 & 0.000 & 273.111 & 1.0000 & 1.1076 & 9.713 & 1.2949 & - & - & - & - \\
\hline
\end{tabular}


Table B-2. Revised Tank 241-AW-106 Boildown Hot Cell Data Log. (3 sheets)

Initial Composite $\operatorname{Vol}^{1{ }^{\circ} \mathrm{C}}(\mathrm{mL})=\operatorname{Vol}^{27.1{ }^{\circ} \mathrm{C}}+\left[\left(\mathrm{Vol}^{27.1^{\circ} \mathrm{C}}\right)(0.00043349 \Delta \mathrm{V} / \mathrm{mL})\left(-9.1 \Delta^{\circ} \mathrm{C}\right)\right]$

Initial Composite $\mathrm{D}_{\text {Model }}{ }^{\circ{ }^{\circ} \mathrm{C}}(\mathrm{g} / \mathrm{mL})=618.199 \mathrm{~g} / \mathrm{Vol}^{18{ }^{\circ} \mathrm{C}}$

$\Delta \mathrm{H}_{2} \mathrm{O}(\mathrm{mL})=\mathrm{Wt} \mathrm{H} \mathrm{H}_{2} \mathrm{O} / \mathrm{D}_{\mathrm{H} 2 \mathrm{O}}{ }^{1{ }^{\circ} \mathrm{C}}$

Sample Rmvd $(\mathrm{mL})=\mathrm{Vol}_{\text {Corrected }}$ based on $\mathrm{Vol}_{\text {Read }}$ measured from sample photograph

\begin{tabular}{|c|c|c|c|c|c|c|c|c|c|c|c|c|c|c|}
\hline \multirow{2}{*}{\multicolumn{2}{|c|}{2013}} & \multirow{3}{*}{ Action } & \multirow{3}{*}{$\begin{array}{c}\text { Sample } \\
\text { Rmvd } \\
(\mathrm{mL})\end{array}$} & \multirow{3}{*}{$\begin{array}{c}\text { Pot Vol } \\
\text { Initial } \\
(\mathrm{mL})\end{array}$} & & & & & $\rho \mathrm{H}_{2} \mathrm{O}$ & 0.9986 & & & & \\
\hline & & & & & \multirow{2}{*}{$\begin{array}{r}\Delta \mathrm{H}_{2} \mathrm{O} \\
(\mathrm{mL}) \\
\end{array}$} & \multirow{2}{*}{$\begin{array}{c}\text { Pot Vol } \\
\text { Final } \\
(\mathrm{mL})\end{array}$} & \multirow{2}{*}{$\begin{array}{c}\text { CR } \\
\text { Step }\end{array}$} & \multirow{2}{*}{$\begin{array}{c}\text { CR } \\
\text { Total }\end{array}$} & \multirow[t]{2}{*}{$\%$ WVR } & \multirow{2}{*}{$\begin{array}{c}\rho \\
\text { Calc } \\
(\mathrm{g} / \mathrm{mL}) \\
\end{array}$} & \multirow{2}{*}{$\begin{array}{c}\mathrm{P} \\
\text { Read } \\
\text { (torr) } \\
\end{array}$} & \multirow{2}{*}{$\begin{array}{c}\mathrm{P} \\
\text { Calc } \\
\text { (torr) } \\
\end{array}$} & \multirow{2}{*}{$\begin{array}{c}\mathrm{T} \\
\text { Read } \\
\left({ }^{\circ} \mathrm{C}\right) \\
\end{array}$} & \multirow{2}{*}{$\begin{array}{c}\mathrm{T} \\
\text { Calc } \\
\left({ }^{\circ} \mathrm{C}\right) \\
\end{array}$} \\
\hline $\begin{array}{c}\text { Date } \\
\mathrm{mm} / \mathrm{dd}\end{array}$ & $\begin{array}{c}\text { Time } \\
\text { hh:mm }\end{array}$ & & & & & & & & & & & & & \\
\hline \multirow[t]{17}{*}{$02 / 20$} & 09:30 & INITIAL & 0.00 & 486.383 & 0.000 & 486.383 & 1.0000 & 1.0000 & 0.000 & 1.2710 & - & - & - & - \\
\hline & $10: 40$ & $\mathrm{P} / \mathrm{T} 0$ [40] & 0.00 & 486.383 & 0.000 & 486.383 & 1.0000 & 1.0000 & 0.000 & 1.2710 & 37 & 40.9 & 37.5 & 38.11 \\
\hline & $10: 55$ & P/T 0 [60] & 0.00 & 486.383 & 0.000 & 486.383 & 1.0000 & 1.0000 & 0.000 & 1.2710 & 57 & 61.1 & 45.5 & 46.04 \\
\hline & 11:00 & $\mathrm{P} / \mathrm{T} 0$ [80] & 0.00 & 486.383 & 0.000 & 486.383 & 1.0000 & 1.0000 & 0.000 & 1.2710 & 76 & 80.3 & 51.4 & 51.86 \\
\hline & 11:10 & CON 1a & 0.00 & 486.383 & 37.303 & 449.080 & 1.0831 & 1.0831 & 7.669 & 1.2936 & - & - & - & - \\
\hline & $12: 34$ & P/T 1a [40] & 0.00 & 449.080 & 0.000 & 449.080 & 1.0000 & 1.0831 & 7.669 & 1.2936 & 36 & 39.9 & 37.9 & 38.51 \\
\hline & $12: 43$ & P/T 1a [60] & 0.00 & 449.080 & 0.000 & 449.080 & 1.0000 & 1.0831 & 7.669 & 1.2936 & 57 & 61.1 & 46.2 & 46.73 \\
\hline & $12: 50$ & P/T 1a [80] & 0.00 & 449.080 & 0.000 & 449.080 & 1.0000 & 1.0831 & 7.669 & 1.2936 & 76 & 80.3 & 51.7 & 52.16 \\
\hline & 13:02 & CON $1 b$ & 0.00 & 449.080 & 39.323 & 409.757 & 1.0960 & 1.1870 & 15.754 & 1.3219 & & - & - & - \\
\hline & $13: 49$ & $\mathrm{P} / \mathrm{T} 1 \mathrm{~b}[40]$ & 0.00 & 409.757 & 0.000 & 409.757 & 1.0000 & 1.1870 & 15.754 & 1.3219 & 35 & 38.9 & 38.3 & 38.86 \\
\hline & $13: 58$ & $\mathrm{P} / \mathrm{T} 1 \mathrm{~b}[60]$ & 0.00 & 409.757 & 0.000 & 409.757 & 1.0000 & 1.1870 & 15.754 & 1.3219 & 57 & 61.1 & 46.8 & 47.32 \\
\hline & 14:04 & $\mathrm{P} / \mathrm{T} 1 \mathrm{~b}[80]$ & 0.00 & 409.757 & 0.000 & 409.757 & 1.0000 & 1.1870 & 15.754 & 1.3219 & 77 & 81.3 & 52.7 & 53.14 \\
\hline & & EON $1 \mathrm{e}$ & 0.00 & 409.757 & 0.000 & 409.757 & 1.0000 & 1.1870 & 15.754 & 1.3219 & - & - & - & - \\
\hline & & $\mathrm{P} / \mathrm{T} 1 \mathrm{c}[40]$ & 0.00 & 409.757 & 0.000 & 409.757 & 1.0000 & 1.1870 & 15.754 & 1.3219 & - & - & - & - \\
\hline & & $\mathrm{P} / \mathrm{T}$ 1c $[60]$ & 0.00 & 409.757 & 0.000 & 409.757 & 1.0000 & 1.1870 & 15.754 & 1.3219 & - & - & - & - \\
\hline & & $\mathrm{P} / \mathrm{T}$ 1c [80] & 0.00 & 409.757 & 0.000 & 409.757 & 1.0000 & 1.1870 & 15.754 & 1.3219 & - & - & - & - \\
\hline & $14: 20$ & Sample Con-1 & 12.54 & 397.217 & 0.000 & 397.217 & 1.0000 & 1.1870 & 15.754 & 1.3219 & - & - & - & - \\
\hline
\end{tabular}


Table B-2. Revised Tank 241-AW-106 Boildown Hot Cell Data Log. (3 sheets)

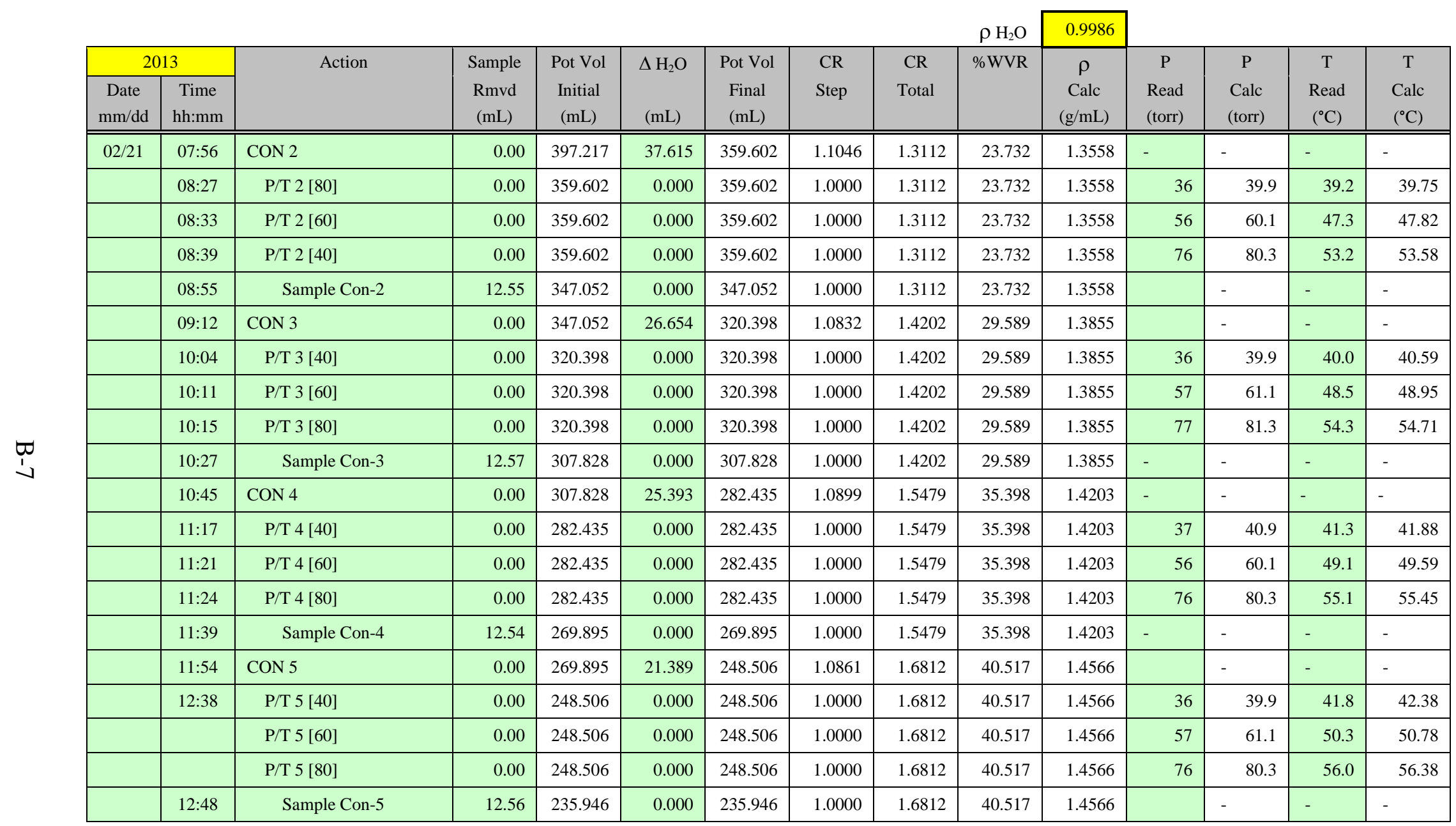


Table B-2. Revised Tank 241-AW-106 Boildown Hot Cell Data Log. (3 sheets)

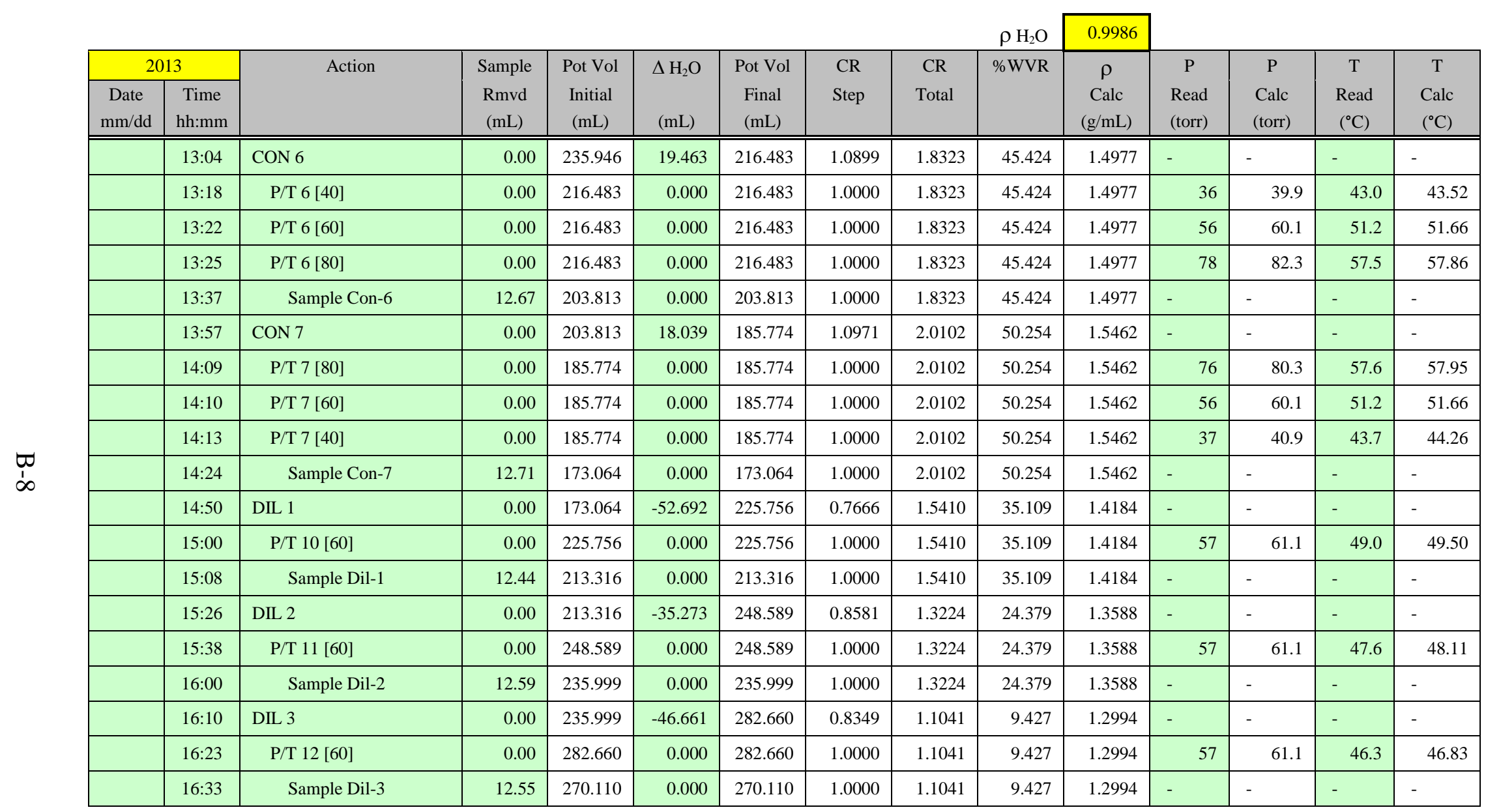


LAB-RPT-13-00003 R0

ATTACHMENT C

PHOTOGRAPHS OF BOILDOWN SAMPLES

$\mathrm{C}-\mathrm{i}$ 
Figure C-1. Tank 241-AW-106 Samples < 1 Hour Out of Pot.

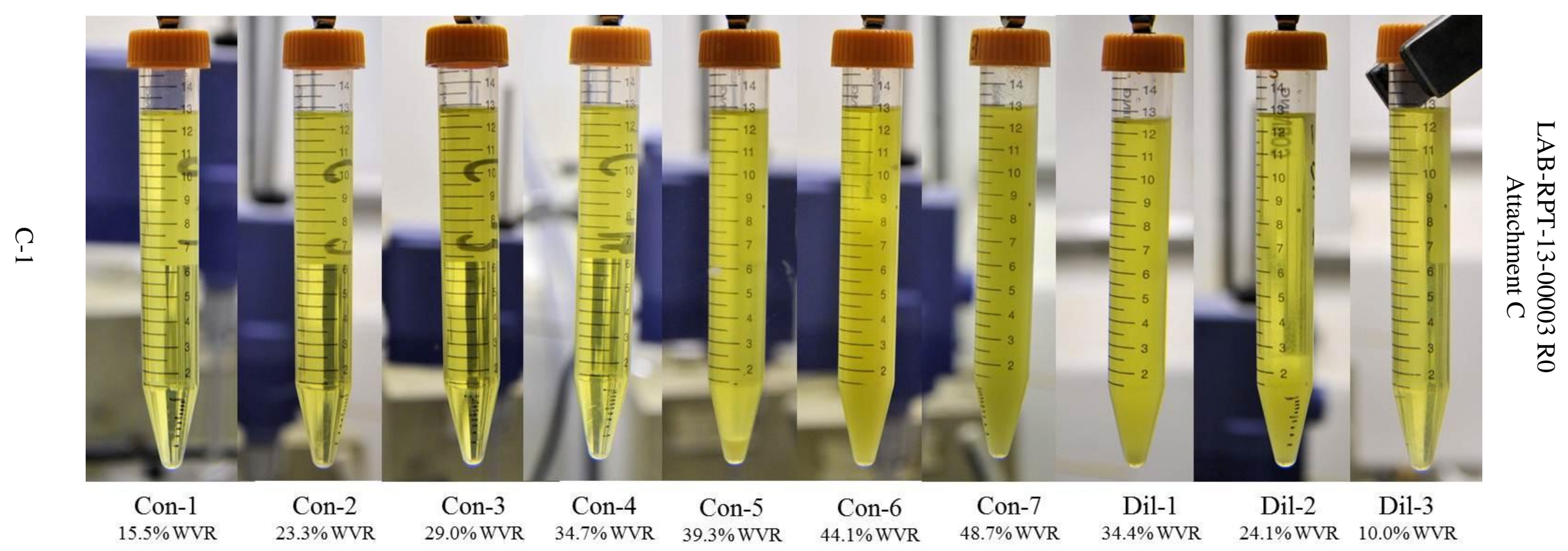


Figure C-2. Tank 241-AW-106 Samples after 1 day at $24.4{ }^{\circ} \mathrm{C}$ in Hot Cell.

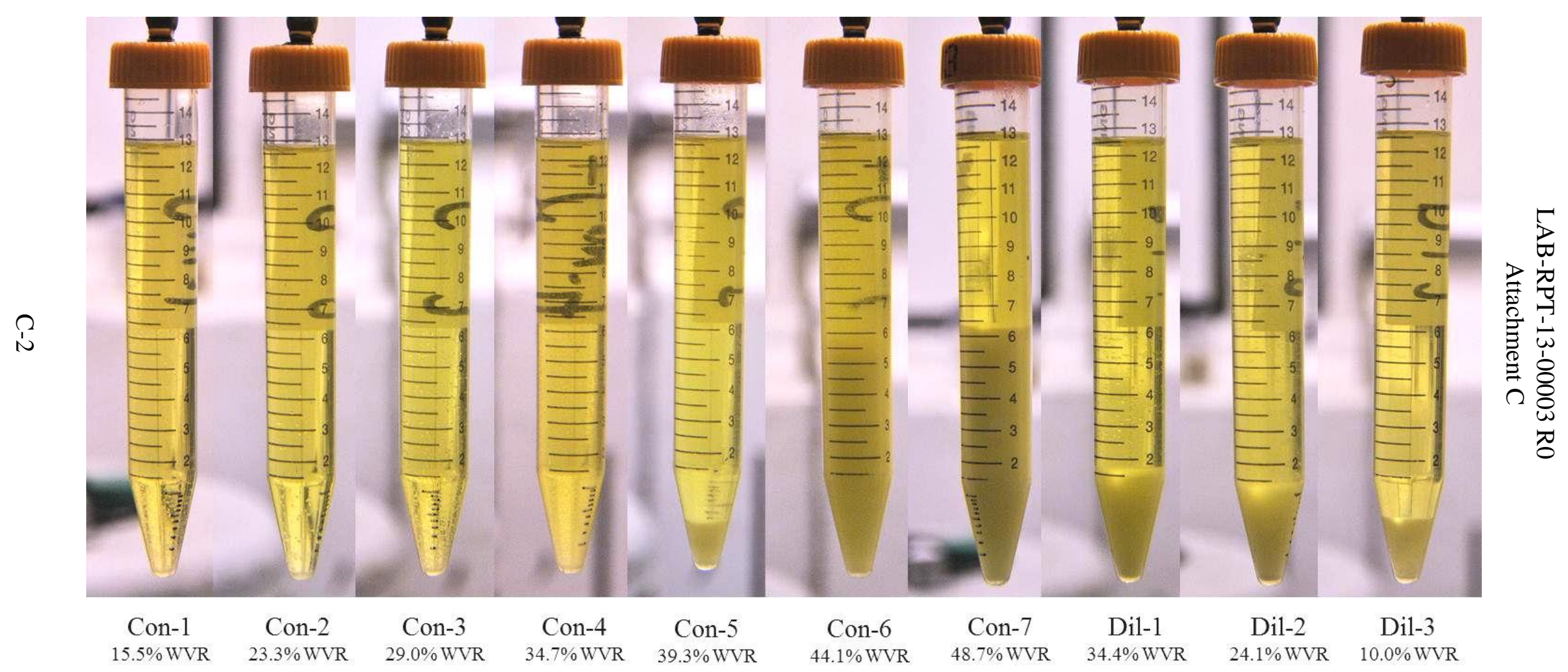


Figure C-3. Tank 241-AW-106 Samples after 5 Days at $18.0{ }^{\circ} \mathrm{C}$.

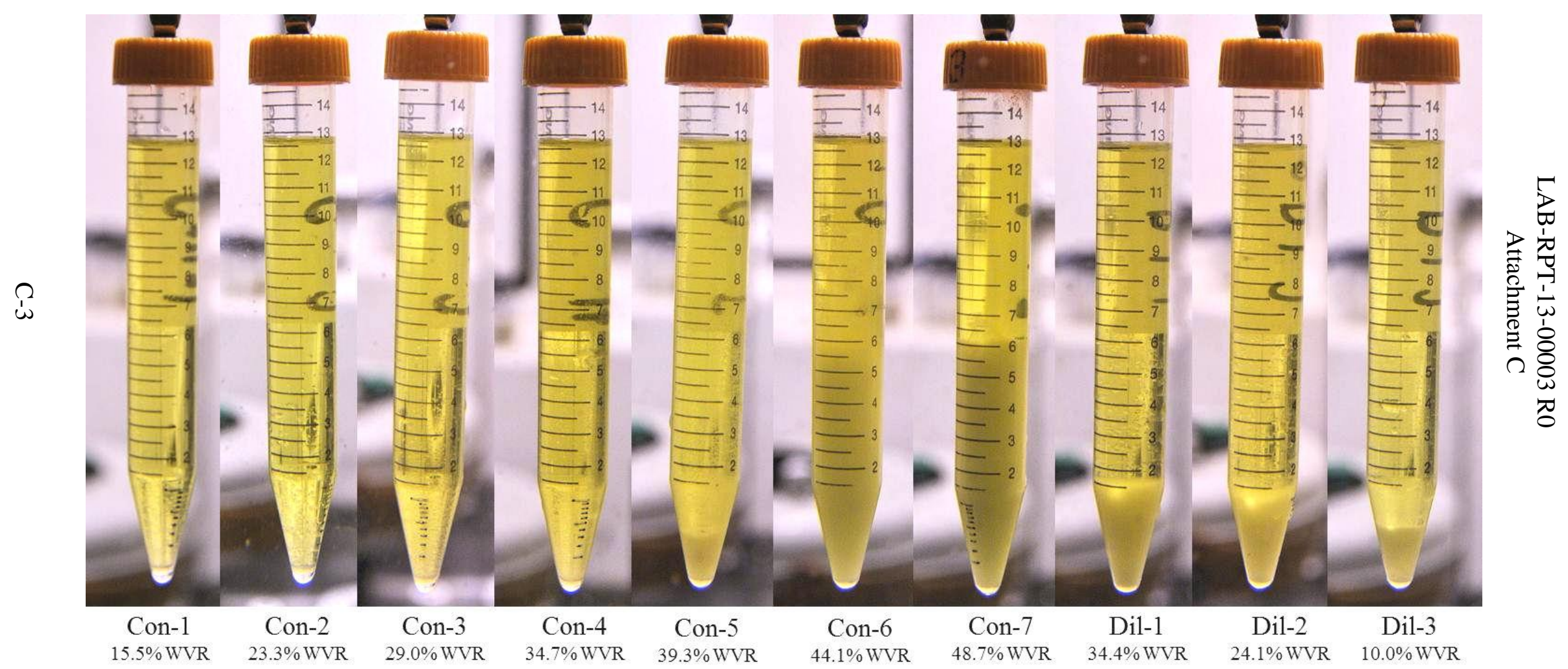


Figure C-4. Tank 241-AW-106 Samples after 5 Days at $18.0{ }^{\circ} \mathrm{C}$ and Centrifuged.

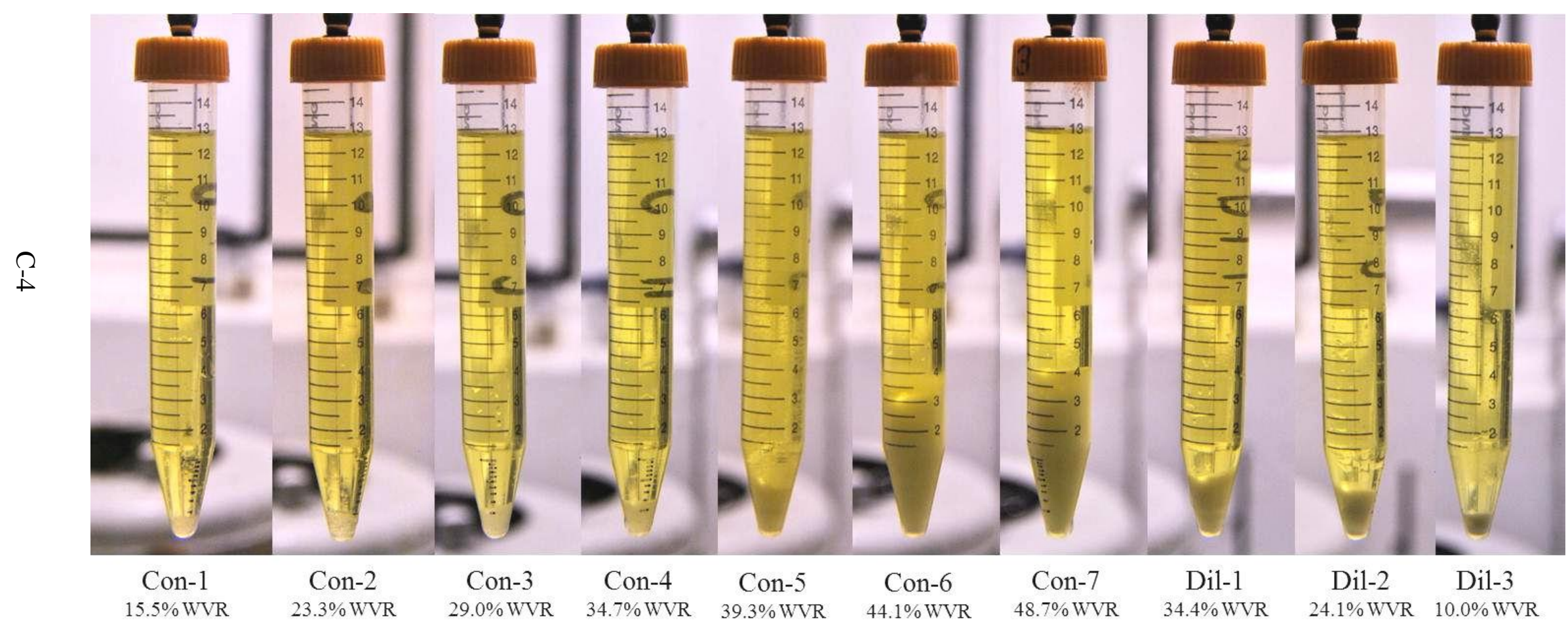

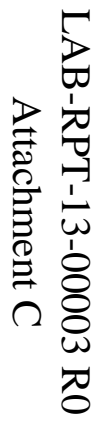


LAB-RPT-13-00003 R0

\section{ATTACHMENT D}

\section{LABORATORY ANALYSIS RESULTS}

D-i 


\section{LABORATORY ANALYSIS RESULTS}

The data summary report for the physicochemical analyses of the AW-106 boildown sample liquids are presented in this attachment. All analyses were performed in the 222-S Laboratory by Advanced Technologies and Laboratories International, Inc. personnel. The following analyses were performed:

\begin{tabular}{|c|c|}
\hline $\begin{array}{l}\text { Component } \\
\text { (Method) }\end{array}$ & $\begin{array}{l}\text { 222-S Procedure } \\
\text { Specific Analytes }\end{array}$ \\
\hline $\begin{array}{l}\text { Density } \\
\quad \text { (gravimetric) }\end{array}$ & $\begin{array}{l}\text { LA-510-112, "Determination of Density for Free Liquid } \\
\text { Samples," Rev/Mod I-0, Advanced Technologies and } \\
\text { Laboratories International, Inc., Richland, Washington. }\end{array}$ \\
\hline $\begin{array}{l}\text { Total inorganic carbon / total organic carbon } \\
\text { (acid-sparging/persulfate-oxidation coulometry) }\end{array}$ & $\begin{array}{l}\text { LA-342-100, "Determination of Carbon by Hot Persulfate } \\
\text { Oxidation and Coulometric Detection," Rev/Mod J-0, } \\
\text { Advanced Technologies and Laboratories International, } \\
\text { Inc., Richland, Washington. }\end{array}$ \\
\hline $\begin{array}{l}\text { Anions } \\
\quad \text { (ion chromatography) }\end{array}$ & $\begin{array}{l}\text { LA-533-166, "Ion Chromatographic Analysis of Anions } \\
\text { and Small Organic Acids on DIONEX Model ICS 3000" } \\
\text { Rev/Mod B-1-A, Advanced Technologies and } \\
\text { Laboratories International, Inc., Richland, Washington. } \\
\mathrm{Br}^{-}, \mathrm{Cl}^{-}, \mathrm{F}^{-}, \mathrm{NO}_{2}^{-}, \mathrm{NO}_{3}^{-}, \mathrm{PO}_{4}{ }^{3-} \text {, and } \mathrm{SO}_{4}{ }^{2-} \text {, and } \\
\text { Small organic anions: formate, acetate, oxalate, and } \\
\text { glycolate. }\end{array}$ \\
\hline $\begin{array}{l}\text { Elemental components } \\
\quad \text { (inductively coupled plasma-atomic emission) }\end{array}$ & $\begin{array}{l}\text { LA-505-174, "Inductively Coupled Plasma (ICP) } \\
\text { Emission Spectrometric Method for the Thermo Scientific } \\
\text { iCAP 6500" Rev/Mod A-0, Advanced Technologies and } \\
\text { Laboratories International, Inc., Richland, Washington. } \\
\text { Priority analytes: Na, Al, Si, P, S, K, Ca, and Cr. All } \\
\text { others reported as opportunistic analytes. }\end{array}$ \\
\hline $\begin{array}{l}\text { Hydroxide } \\
\quad \text { (potentiometric titration) }\end{array}$ & $\begin{array}{l}\text { LA-211-102, "Determination of Free OH-/+ Using } \\
\text { Metrohm Titrando," Rev/Mod I-1, Advanced } \\
\text { Technologies and Laboratories International, Inc., } \\
\text { Richland, Washington. }\end{array}$ \\
\hline $\begin{array}{l}\text { Total carbon } \\
\quad \text { (combustion-coulometry) }\end{array}$ & $\begin{array}{l}\text { LA-344-105, "Determination of Carbon in Solutions by } \\
\text { Combustion and Coulometry," Rev/Mod J-0, Advanced } \\
\text { Technologies and Laboratories International, Inc., } \\
\text { Richland, Washington. }\end{array}$ \\
\hline
\end{tabular}

The quality assurance data 'flags' in the right-most column of the data summary tables are defined as follows:

\begin{tabular}{|l|l|}
\hline $\mathbf{J}$ & Estimated \\
\hline $\mathrm{U}$ & Less than detection limit \\
\hline
\end{tabular}


Table D-1. Tank 241-AW-106 Boildown Chemical Analysis Results for all Submitted Liquid Samples (20 sheets)

AW106 BLDN 2013

Data Summary Report

Sample Group: 20130122

Customer Group or SDG Number:

Segment Portion: Tank Composite (Supernatant Liquid)

Parent Sample Number: S13T001219

\begin{tabular}{|c|c|c|c|c|c|c|c|c|c|c|c|c|c|c|}
\hline Sample\# $\mathbf{R}$ & A\# & CAS \# & Analyte & Unit & STD \% & Blank & Result & Duplicate & Average & RPD \% & Spk Rec \% & Det Limit & Cnt Err \% & Qual Flags \\
\hline \multicolumn{15}{|c|}{ Anions and Small Organic Acids } \\
\hline S13T00 1220 & & $16984-48-8$ & Fluoride & ug $/ \mathrm{mL}$ & 95.8 & $<1.61 \mathrm{E}-03$ & $1.42 E+03$ & $\mathrm{n} / \mathrm{a}$ & $\mathrm{n} / \mathrm{a}$ & $\mathrm{n} / \mathrm{a}$ & $\mathrm{n} / \mathrm{a}$ & 24.2 & $\mathrm{n} / \mathrm{a}$ & \\
\hline S13T00 1220 & & $866-14-8$ & Glycolate & $\mathrm{ug} / \mathrm{mL}$ & 95.4 & $<9.37 \mathrm{E}-03$ & $<141$ & $\mathrm{n} / \mathrm{a}$ & $\mathrm{n} / \mathrm{a}$ & $\mathrm{n} / \mathrm{a}$ & $n / a$ & 141 & $n / a$ & $\mathrm{u}$ \\
\hline S13T00 1220 & & 71-50-1 & Acetate & ug $/ \mathrm{mL}$ & 93.4 & $<6.04 \mathrm{E}-03$ & 537 & $\mathrm{n} / \mathrm{a}$ & $\mathrm{n} / \mathrm{a}$ & $\mathrm{n} / \mathrm{a}$ & $n / a$ & 90.6 & $\mathrm{n} / \mathrm{a}$ & $\mathrm{J}$ \\
\hline S13T00 1220 & & $12311-97-6$ & Formate & $\mathrm{ug} / \mathrm{mL}$ & 97.2 & $<4.67 \mathrm{E}-03$ & $1.21 \mathrm{E}+03$ & $\mathrm{n} / \mathrm{a}$ & $\mathrm{n} / \mathrm{a}$ & $\mathrm{n} / \mathrm{a}$ & $n / a$ & 70.0 & $\mathrm{n} / \mathrm{a}$ & $\mathrm{J}$ \\
\hline$S 13 T 001220$ & & $16887-00-6$ & Chloride & $\mathrm{ug} / \mathrm{mL}$ & 96.3 & 0.0110 & $1.69 \mathrm{E}+03$ & $n / a$ & $\mathrm{n} / \mathrm{a}$ & $\mathrm{n} / \mathrm{a}$ & $n / a$ & 150 & $n / a$ & \\
\hline S13T00 1220 & & $14797-65-0$ & Nitrite & $\mathrm{ug} / \mathrm{mL}$ & 104 & $<0.0192$ & $3.83 E+04$ & $\mathrm{n} / \mathrm{a}$ & $\mathrm{n} / \mathrm{a}$ & $\mathrm{n} / \mathrm{a}$ & $n / a$ & 288 & $n / a$ & \\
\hline S13T00 1220 & & $14808-79-8$ & Sulfate & $\mathrm{ug} / \mathrm{mL}$ & 96.2 & $<0.0187$ & $6.67 E+03$ & $\mathrm{n} / \mathrm{a}$ & $\mathrm{n} / \mathrm{a}$ & $\mathrm{n} / \mathrm{a}$ & $n / a$ & 280 & $\mathrm{n} / \mathrm{a}$ & \\
\hline S13T00 1220 & & $338-70-5$ & Oxalate & $\mathrm{ug} / \mathrm{mL}$ & 97.4 & $<0.0231$ & 433 & $n / a$ & $\mathrm{n} / \mathrm{a}$ & $\mathrm{n} / \mathrm{a}$ & $\mathrm{n} / \mathrm{a}$ & 346 & $\mathrm{n} / \mathrm{a}$ & $\mathrm{J}$ \\
\hline $\mathrm{S} 13 \mathrm{~T} 001220$ & & $24959-67-9$ & Bromide & $\mathrm{ug} / \mathrm{mL}$ & 97.2 & $<0.0580$ & $<870$ & $\mathrm{n} / \mathrm{a}$ & $\mathrm{n} / \mathrm{a}$ & $\mathrm{n} / \mathrm{a}$ & $n / a$ & 870 & $n / a$ & $u$ \\
\hline $\mathrm{S} 13 \mathrm{~T} 001220$ & & $14797-55-8$ & Nitrate & $\mathrm{ug} / \mathrm{mL}$ & 95.6 & $<0.0208$ & $1.37 E+05$ & $n / a$ & $n / a$ & $\mathrm{n} / \mathrm{a}$ & $n / a$ & 312 & $n / a$ & \\
\hline S13T00 1220 & & $14265-44-2$ & Phosphate & ug $/ \mathrm{mL}$ & 96.8 & $<0.0167$ & $2.28 \mathrm{E}+03$ & $\mathrm{n} / \mathrm{a}$ & $\mathrm{n} / \mathrm{a}$ & $\mathrm{n} / \mathrm{a}$ & $\mathrm{n} / \mathrm{a}$ & 250 & $n / a$ & $\mathrm{~J}$ \\
\hline \multicolumn{15}{|l|}{ DENSITY } \\
\hline S13T00 1221 & & Density & Density & $g / \mathrm{mL}$ & 99.42 & $n / a$ & 1.255 & 1.246 & 1.250 & 0.6878 & $n / a$ & $1.000 \mathrm{E}-03$ & $\mathrm{n} / \mathrm{a}$ & \\
\hline \multicolumn{15}{|c|}{ ICP-RCRA Metals } \\
\hline S13T00 1221 & & $7429-90-5$ & Aluminum & ug $/ \mathrm{mL}$ & 95.5 & $<6.00 \mathrm{E}-03$ & $5.87 E+03$ & $5.86 \mathrm{E}+03$ & $5.87 E+03$ & 0.0861 & 82.4 & 12.0 & $\mathrm{n} / \mathrm{a}$ & \\
\hline S13T00 1221 & & $7440-38-2$ & Arsenic & $\mathrm{ug} / \mathrm{mL}$ & 99.2 & $<5.00 \mathrm{E}-03$ & $<10.0$ & $<10.0$ & $\mathrm{n} / \mathrm{a}$ & $\mathrm{n} / \mathrm{a}$ & 98.8 & 10.0 & $n / a$ & $u$ \\
\hline S13T00 1221 & & $7440-39-3$ & Barium & $u g / m L$ & 101 & $<1.00 \mathrm{E}-03$ & $<2.00$ & $<2.00$ & $\mathrm{n} / \mathrm{a}$ & $\mathrm{n} / \mathrm{a}$ & 98.4 & 2.00 & $\mathrm{n} / \mathrm{a}$ & $u$ \\
\hline S13T001221 & & $7440-41-7$ & Beryllium & $\mathrm{ug} / \mathrm{mL}$ & 102 & $<1.00 \mathrm{E}-03$ & $<2.00$ & $<2.00$ & $\mathrm{n} / \mathrm{a}$ & $\mathrm{n} / \mathrm{a}$ & 104 & 2.00 & $\mathrm{n} / \mathrm{a}$ & $u$ \\
\hline S13T001221 & & $7440-70-2$ & Calcium & $\mathrm{ug} / \mathrm{mL}$ & 95.5 & $<0.0800$ & $<160$ & $<160$ & $\mathrm{n} / \mathrm{a}$ & $\mathrm{n} / \mathrm{a}$ & 90.4 & 160 & $\mathrm{n} / \mathrm{a}$ & u \\
\hline S13T00 1221 & & $7440-43-8$ & Cadmium & ug $/ \mathrm{mL}$ & 97.0 & $<1.00 \mathrm{E}-03$ & 2.81 & 2.82 & 2.82 & 0.497 & 81.4 & 2.00 & $n / a$, & $\mathrm{J}$ \\
\hline S13T001221 & & $7440-47-3$ & Chromium & ug $/ \mathrm{mL}$ & 101 & $<1.00 \mathrm{E}-03$ & 485 & 484 & 484 & 0.278 & 102 & 2.00 & $n / a$ & \\
\hline S13T00 1221 & & $7440-53-1$ & Europium & ug $/ \mathrm{mL}$ & 100 & $<1.00 \mathrm{E}-03$ & $<2.00$ & $<2.00$ & $\mathrm{n} / \mathrm{a}$ & $\mathrm{n} / \mathrm{a}$ & 99.6 & 2.00 & $n / a$ & u \\
\hline S13T00 1221 & & $7439-89-6$ & \begin{tabular}{|l|} 
Iron \\
\end{tabular} & $\mathrm{ug} / \mathrm{mL}$ & 103 & $<0.0100$ & 47.1 & 48.9 & 48.0 & 3.86 & 104 & 20.0 & $n / a$ & $\mathrm{~J}$ \\
\hline S13T001221 & & $7440-09-7$ & Potassium & $\mathrm{ug} / \mathrm{mL}$ & 98.7 & $<0.0200$ & $4.42 E+03$ & $4.42 E+03$ & $4.42 E+03$ & 0.0138 & 96.7 & 40.0 & $\mathrm{n} / \mathrm{a}$ & \\
\hline S13T00 1221 & & 7439-91-0 & Lanthanum & $\mathrm{ug} / \mathrm{mL}$ & 104 & $<1.00 \mathrm{E}-03$ & $<2.00$ & $<2.00$ & $\mathrm{n} / \mathrm{a}$ & $\mathrm{n} / \mathrm{a}$ & 107 & 2.00 & $\mathrm{n} / \mathrm{a}$ & $u$ \\
\hline S13T001221 & & 7439-93-2 & Lithium & $\mathrm{ug} / \mathrm{mL}$ & 105 & $<1.00 \mathrm{E}-03$ & $<2.00$ & $<2.00$ & $\mathrm{n} / \mathrm{a}$ & $\mathrm{n} / \mathrm{a}$ & 102 & 2.00 & $\mathrm{n} / \mathrm{a}$ & u \\
\hline S13T00 1221 & & $7439-98-7$ & Molybdenum & $\mathrm{ug} / \mathrm{mL}$ & 96.0 & $<1.00 \mathrm{E}-03$ & 22.6 & 22.6 & 22.6 & 0.0892 & 92.7 & 2.00 & $n / a$ & \\
\hline
\end{tabular}


Table D-1. Tank 241-AW-106 Boildown Chemical Analysis Results for all Submitted Liquid Samples (20 sheets)

AW106 BLDN 2013

Data Summary Report

Sample Group: 20130122

Customer Group or SDG Number:

Segment Portion: Tank Composite (Supernatant Liquid)

Parent Sample Number: S13T001219

\begin{tabular}{|c|c|c|c|c|c|c|c|c|c|c|c|c|c|c|}
\hline \begin{tabular}{|ll} 
Sample\# & R \\
\end{tabular} & A\# & CAS\# & Analyte & Unit & STD \% & Blank & Result & Duplicate & Average & RPD \% & \begin{tabular}{|l|l|} 
Spk Rec $\%$ & \\
\end{tabular} & Det Limit & Cnt Err \% & Qual Flags \\
\hline \multicolumn{15}{|c|}{ ICP-RCRA Metals } \\
\hline S13T001221 & & $7440-23-5$ & Sodium & $\mathrm{ug} / \mathrm{mL}$ & 96.0 & $<0.0400$ & $1.27 E+05$ & $1.27 E+05$ & $1.27 \mathrm{E}+05$ & 0.476 & 85.0 & 80.0 & $n / a$ & \\
\hline S13T001221 & & $7440-02-0$ & Nickel & $\mathrm{ug} / \mathrm{mL}$ & 100 & $<1.00 \mathrm{E}-03$ & 21.6 & 21.2 & 21.4 & 1.84 & 96.1 & 2.00 & $n / a$ & \\
\hline S13T001221 & & $7723-14-0$ & Phosphorus & $\mathrm{ug} / \mathrm{mL}$ & 96.1 & $<3.00 \mathrm{E}-03$ & 693 & 686 & 690 & 0.918 & 91.8 & 6.00 & $n / a$ & \\
\hline S13T001221 & & $7439-92-1$ & Lead & $\mathrm{ug} / \mathrm{mL}$ & 104 & $<6.00 \mathrm{E}-03$ & $<12.0$ & $<12.0$ & $\mathrm{n} / \mathrm{a}$ & $\mathrm{n} / \mathrm{a}$ & 101 & 12.0 & $\mathrm{n} / \mathrm{a}$ & u \\
\hline S13T001221 & & $7704-34-9$ & Sulfur & $u g / m L$ & 100 & $<5.00 \mathrm{E}-03$ & $2.17 \mathrm{E}+03$ & $2.16 \mathrm{E}+03$ & $2.16 \mathrm{E}+03$ & 0.222 & 102 & 10.0 & $n / a$ & \\
\hline S13T001221 & & $7782-49-2$ & Selenium & $\mathrm{ug} / \mathrm{mL}$ & 99.0 & $<6.00 \mathrm{E}-03$ & $<12.0$ & $<12.0$ & $\mathrm{n} / \mathrm{a}$ & $n / a$ & 99.2 & 12.0 & $n / a$ & $\mathrm{u}$ \\
\hline S13T001221 & & $7440-21-3$ & Silicon & $\mathrm{ug} / \mathrm{mL}$ & 103 & $<5.00 \mathrm{E}-03$ & 50.5 & 53.8 & 52.2 & 6.34 & 104 & 10.0 & $n / a$. & $\mathrm{J}$ \\
\hline S13T001221 & & $7440-24-6$ & Strontium & $u g / \mathrm{mL}$ & 100 & $<2.00 \mathrm{E}-03$ & $<4.00$ & $<4.00$ & $n / a$ & $\mathrm{n} / \mathrm{a}$ & 96.0 & 4.00 & $n / a$ & $\mathrm{u}$ \\
\hline S13T001221 & & $7440-32-6$ & Titanium & $\mathrm{ug} / \mathrm{mL}$ & 97.8 & $<1.00 \mathrm{E}-03$ & $<2.00$ & $<2.00$ & $\mathrm{n} / \mathrm{a}$ & $\mathrm{n} / \mathrm{a}$ & 97.8 & 2.00 & $n / a$ & $\mathrm{u}$ \\
\hline S13T001221 & & $7440-28-0$ & Thallium & $u g / m L$ & 97.3 & $<6.00 \mathrm{E}-03$ & $<12.0$ & $<12.0$ & $\mathrm{n} / \mathrm{a}$ & $\mathrm{n} / \mathrm{a}$ & 82.5 & 12.0 & $n / a$ & $u$ \\
\hline S13T001221 & & $7440-66-6$ & Zinc & $u g / m L$ & 100 & $<4.00 \mathrm{E}-03$ & $<8.00$ & $<8.00$ & $\mathrm{n} / \mathrm{a}$ & $\mathrm{n} / \mathrm{a}$ & 98.7 & 8.00 & $n / a$ & $\mathrm{u}$ \\
\hline S13T001221 & & $7440-67-7$ & Zirconium & $\mathrm{ug} / \mathrm{mL}$ & 98.2 & $<1.00 \mathrm{E}-03$ & $<2.00$ & 2.08 & $n / a$ & $\mathrm{n} / \mathrm{a}$ & 104 & 2.00 & $n / a$ & u \\
\hline \multicolumn{15}{|c|}{$\mathrm{OH}$ - by Pot. Titration } \\
\hline S13T001221 & & HYDROXIDE & Hydroxide & $u g / \mathrm{mL}$ & 88.8 & $<9.22$ & $1.21 E+04$ & $1.23 E+04$ & $1.22 \mathrm{E}+04$ & 1.38 & 99.8 & 553 & $n / a$ & \\
\hline \multicolumn{15}{|c|}{ TIC/TOC by Acid Persulfate } \\
\hline S13T001220 & & TIC & Total inorganic carbon & $\mathrm{ug} / \mathrm{mL}$ & 101 & $<7.00$ & $6.56 \mathrm{E}+03$ & $6.10 \mathrm{E}+03$ & $6.33 \mathrm{E}+03$ & 7.27 & 102 & 35.0 & $n / a$ & \\
\hline S13T001220 & & TOC & Total organic carbon & $\mathrm{ug} / \mathrm{mL}$ & 89.1 & $<20.0$ & $1.38 E+03$ & $1.30 \mathrm{E}+03$ & $1.34 E+03$ & 5.97 & 95.6 & 100 & $n / a$ & \\
\hline \multicolumn{15}{|c|}{ Total Carbon by Furnace } \\
\hline S13T001220 & & TC & Total carbon & $\mathrm{ug} / \mathrm{mL}$ & 100 & 10.5 & $7.96 \mathrm{E}+03$ & $7.59 \mathrm{E}+03$ & $7.78 \mathrm{E}+03$ & 4.76 & 84.6 & 305 & $n / a$ & \\
\hline \multicolumn{15}{|c|}{ Parent Sample Number: S13T001225 } \\
\hline \begin{tabular}{|ll} 
Sample\# & $\mathbf{R}$ \\
\end{tabular} & A\# & CAS\# & Analyte & Unit & STD \% & Blank & Result & Duplicate & Average & RPD \% & Spk Rec \% & Det Limit & Cnt Err \% & Qual Flags \\
\hline \multicolumn{15}{|c|}{ Anions and Small Organic Acids } \\
\hline S13T001234 & & $16984-48-8$ & Fluoride & $\mathrm{ug} / \mathrm{mL}$ & 94.5 & $<1.61 \mathrm{E}-03$ & $1.66 \mathrm{E}+03$ & $n / a$ & $n / a$ & $n / a$ & $n / a$ & 24.2 & $n / a$ & \\
\hline S13T001234 & & 686-14-8 & Glycolate & $\mathrm{ug} / \mathrm{mL}$ & 94.0 & $<9.37 \mathrm{E}-03$ & 743 & $n / a$ & $n / a$ & $n / a$ & $n / a$ & 141 & $n / a$ & $\mathrm{~J}$ \\
\hline S13T001234 & & $71-50-1$ & Acetate & $\mathrm{ug} / \mathrm{mL}$ & 91.4 & $<6.04 \mathrm{E}-03$ & 747 & $\mathrm{n} / \mathrm{a}$ & $\mathrm{n} / \mathrm{a}$ & $\mathrm{n} / \mathrm{a}$ & $n / a$ & 90.6 & $n / a$ & $\mathrm{~J}$ \\
\hline S13T00 1234 & & $12311-87-6$ & Formate & $\mathrm{ug} / \mathrm{mL}$ & 96.6 & $<4.67 \mathrm{E}-03$ & $1.52 \mathrm{E}+03$ & $\mathrm{n} / \mathrm{a}$ & $\mathrm{n} / \mathrm{a}$ & $\mathrm{n} / \mathrm{a}$ & $\mathrm{n} / \mathrm{a}$ & 70.0 & $\mathrm{n} / \mathrm{a}$ & $\mathrm{J}$ \\
\hline S13T001234 & & $16887-00-6$ & Chloride & $\mathrm{ug} / \mathrm{mL}$ & 94.0 & $<9.98 \mathrm{E}-03$ & $2.43 E+03$ & $n / a$ & $n / a$ & $n / a$ & $n / a$ & 150 & $n / a$ & \\
\hline
\end{tabular}


Table D-1. Tank 241-AW-106 Boildown Chemical Analysis Results for all Submitted Liquid Samples (20 sheets)

AW106 BLDN 2013

Data Summary Report

Sample Group: 20130122

Customer Group or SDG Number:

Segment Portion: Tank Composite (Supernatant Liquid)

Parent Sample Number: S13T001225

\begin{tabular}{|c|c|c|c|c|c|c|c|c|c|c|c|c|c|c|}
\hline Sample\# $\mathbf{R}$ & A\# & CAS\# & Analyte & Unit & STD \% & Blank & Result & Duplicate & Average & RPD \% & Spk Rec \% & Det Limit & Cnt Err \% & Qual Flags \\
\hline \multicolumn{15}{|c|}{ Anions and Small Organic Acids } \\
\hline S13T001234 & & $14797-65-0$ & Nitrite & $\mathrm{ug} / \mathrm{mL}$ & 102 & $<0.0192$ & $5.26 \mathrm{E}+04$ & $\mathrm{n} / \mathrm{a}$ & $\mathrm{n} / \mathrm{a}$ & $\mathrm{n} / \mathrm{a}$ & $n / a$ & 288 & $n / a$ & \\
\hline S13T00 1234 & & $14808-79-8$ & Sulfate & $\mathrm{ug} / \mathrm{mL}$ & 95.3 & $<0.0187$ & $7.79 \mathrm{E}+03$ & $\mathrm{n} / \mathrm{a}$ & $n / a$ & $\mathrm{n} / \mathrm{a}$ & $n / a$ & 280 & $n / a$ & \\
\hline S13T001234 & & $338-70-5$ & Oxalate & $\mathrm{ug} / \mathrm{mL}$ & 97.0 & $<0.0231$ & 703 & $\mathrm{n} / \mathrm{a}$ & $n / a$ & $n / a$ & $n / a$ & 346 & $n / a$. & $\mathrm{J}$ \\
\hline S13T001234 & & $24959-67-9$ & Bromide & $\mathrm{ug} / \mathrm{mL}$ & 96.8 & $<0.0580$ & $<870$ & $\mathrm{n} / \mathrm{a}$ & $n / a$ & $n / a$ & $n / a$ & 870 & $n / a$ & u \\
\hline S13T001234 & & $14797-55-8$ & Nitrate & $\mathrm{ug} / \mathrm{mL}$ & 94.5 & $<0.0208$ & $1.88 \mathrm{E}+05$ & $n / a$ & $n / a$ & $n / a$ & $n / a$ & 312 & $n / a$ & \\
\hline S13T001234 & & $14265-44-2$ & Phosphate & $u g / m L$ & 95.1 & $<0.0167$ & $<250$ & $\mathrm{n} / \mathrm{a}$ & $n / a$ & $n / a$ & $n / a$ & 250 & $n / a$ & u \\
\hline \multicolumn{15}{|l|}{ DENSITY } \\
\hline S13T001234 & & Density & Density & $\mathrm{g} / \mathrm{mL}$ & 99.42 & $n / a$ & 1.291 & $\mathrm{n} / \mathrm{a}$ & $n / a$ & $\mathrm{n} / \mathrm{a}$ & $\mathrm{n} / \mathrm{a}$ & $1.000 \mathrm{E}-03$ & $n / a$ & \\
\hline \multicolumn{15}{|c|}{ ICP-RCRA Metals } \\
\hline S13T001234 & & $7429-90-5$ & Aluminum & $\mathrm{ug} / \mathrm{mL}$ & 95.5 & $<6.00 \mathrm{E}-03$ & $7.03 E+03$ & $n / a$ & $\mathrm{n} / \mathrm{a}$ & $\mathrm{n} / \mathrm{a}$ & $\mathrm{n} / \mathrm{a}$ & 12.0 & $n / a$ & \\
\hline S13T001234 & & $7440-38-2$ & Arsenic & $\mathrm{ug} / \mathrm{mL}$ & 99.2 & $<5.00 \mathrm{E}-03$ & $<10.0$ & $\mathrm{n} / \mathrm{a}$ & $\mathrm{n} / \mathrm{a}$ & $\mathrm{n} / \mathrm{a}$ & $\mathrm{n} / \mathrm{a}$ & 10.0 & $n / a)$ & u \\
\hline S13T001234 & & $7440-39-3$ & Barium & $\mathrm{ug} / \mathrm{mL}$ & 101 & $<1.00 \mathrm{E}-03$ & $<2.00$ & $\mathrm{n} / \mathrm{a}$ & $\mathrm{n} / \mathrm{a}$ & $\mathrm{n} / \mathrm{a}$ & $\mathrm{n} / \mathrm{a}$ & 2.00 & $n / a)$ & u \\
\hline S13T001234 & & $7440-41-7$ & Beryllium & $\mathrm{ug} / \mathrm{mL}$ & 102 & $<1.00 \mathrm{E}-03$ & $<2.00$ & $\mathrm{n} / \mathrm{a}$ & $n / a$ & $\mathrm{n} / \mathrm{a}$ & $\mathrm{n} / \mathrm{a}$ & 2.00 & $n / a$ & $\mathrm{u}$ \\
\hline S13T00 1234 & & $7440-70-2$ & Calcium & $\mathrm{ug} / \mathrm{mL}$ & 95.5 & $<0.0800$ & $<160$ & $n / a$ & $\mathrm{n} / \mathrm{a}$ & $n / a$ & $n / a$ & 160 & $n / a$ & u \\
\hline S13T001234 & & $7440-43-8$ & Cadmium & $\mathrm{ug} / \mathrm{mL}$ & 97.0 & $<1.00 \mathrm{E}-03$ & 3.19 & $n / a$ & $n / a$ & $n / a$ & $n / a$ & 2.00 & $n / a$. & $\mathrm{J}$ \\
\hline S13T001234 & & $7440-47-3$ & Chromium & $\mathrm{ug} / \mathrm{mL}$ & 101 & $<1.00 \mathrm{E}-03$ & 594 & $n / a$ & $\mathrm{n} / \mathrm{a}$ & $n / a$ & $n / a$ & 2.00 & $n / a$ & \\
\hline S13T001234 & & $7440-53-1$ & Europium & $u g / m L$ & 100 & $<1.00 \mathrm{E}-03$ & $<2.00$ & $n / a$ & $n / a$ & $\mathrm{n} / \mathrm{a}$ & $\mathrm{n} / \mathrm{a}$ & 2.00 & $n / a$ & u \\
\hline S13T001234 & & $7439-89-6$ & Iron & $\mathrm{ug} / \mathrm{mL}$ & 103 & $<0.0100$ & 49.1 & $n / a$ & $\mathrm{n} / \mathrm{a}$ & $\mathrm{n} / \mathrm{a}$ & $\mathrm{n} / \mathrm{a}$ & 20.0 & $n / a$ & $\mathrm{~J}$ \\
\hline S13T00 1234 & & $7440-09-7$ & Potassium & $\mathrm{ug} / \mathrm{mL}$ & 98.7 & $<0.0200$ & $5.20 \mathrm{E}+03$ & $\mathrm{n} / \mathrm{a}$ & $\mathrm{n} / \mathrm{a}$ & $\mathrm{n} / \mathrm{a}$ & $\mathrm{n} / \mathrm{a}$ & 40.0 & $n / a$ & \\
\hline S13T001234 & & 7439-91-0 & Lanthanum & $\mathrm{ug} / \mathrm{mL}$ & 104 & $<1.00 \mathrm{E}-03$ & $<2.00$ & $\mathrm{n} / \mathrm{a}$ & $n / a$ & $\mathrm{n} / \mathrm{a}$ & $\mathrm{n} / \mathrm{a}$ & 2.00 & $n / a)$ & u \\
\hline S13T001234 & & 7439-93-2 & Lithium & $\mathrm{ug} / \mathrm{mL}$ & 105 & $<1.00 \mathrm{E}-03$ & $<2.00$ & $\mathrm{n} / \mathrm{a}$ & $\mathrm{n} / \mathrm{a}$ & $\mathrm{n} / \mathrm{a}$ & $\mathrm{n} / \mathrm{a}$ & 2.00 & $n / a$ & u \\
\hline S13T001234 & & $7439-98-7$ & Molybdenum & $\mathrm{ug} / \mathrm{mL}$ & 98.0 & $<1.00 \mathrm{E}-03$ & 28.6 & $\mathrm{n} / \mathrm{a}$ & $n / a$ & $\mathrm{n} / \mathrm{a}$ & $\mathrm{n} / \mathrm{a}$ & 2.00 & $n / a$ & \\
\hline S13T00 1234 & & $7440-23-5$ & Sodium & $\mathrm{ug} / \mathrm{mL}$ & 96.0 & $<0.0400$ & $1.49 \mathrm{E}+05$ & $\mathrm{n} / \mathrm{a}$ & $\mathrm{n} / \mathrm{a}$ & $\mathrm{n} / \mathrm{a}$ & $n / a$ & 80.0 & $n / a$ & \\
\hline S13T001234 & & $7440-02-0$ & Nickel & $\mathrm{ug} / \mathrm{mL}$ & 100 & $<1.00 \mathrm{E}-03$ & 23.8 & $\mathrm{n} / \mathrm{a}$ & $\mathrm{n} / \mathrm{a}$ & $\mathrm{n} / \mathrm{a}$ & $n / a$ & 2.00 & $n / a$ & \\
\hline S13T00 1234 & & $7723-14-0$ & Phosphorus & $\mathrm{ug} / \mathrm{mL}$ & 96.1 & $<3.00 \mathrm{E}-03$ & 403 & $\mathrm{n} / \mathrm{a}$ & $\mathrm{n} / \mathrm{a}$ & $\mathrm{n} / \mathrm{a}$ & $\mathrm{n} / \mathrm{a}$ & 6.00 & $n / a$ & \\
\hline S13T00 1234 & & $7439-92-1$ & Lead & $\mathrm{ug} / \mathrm{mL}$ & 104 & $<6.00 \mathrm{E}-03$ & $<12.0$ & $\mathrm{n} / \mathrm{a}$ & $\mathrm{n} / \mathrm{a}$ & $\mathrm{n} / \mathrm{a}$ & $\mathrm{n} / \mathrm{a}$ & 12.0 & $n / a$ & u \\
\hline S13T001234 & & $7704-34-9$ & Sulfur & $\mathrm{ug} / \mathrm{mL}$ & 100 & $<5.00 \mathrm{E}-03$ & $2.52 \mathrm{E}+03$ & $n / a$ & $\mathrm{n} / \mathrm{a}$ & $\mathrm{n} / \mathrm{a}$ & $\mathrm{n} / \mathrm{a}$ & 10.0 & $n / a$ & \\
\hline
\end{tabular}


Table D-1. Tank 241-AW-106 Boildown Chemical Analysis Results for all Submitted Liquid Samples (20 sheets)

AW106 BLDN 2013

Data Summary Report

Sample Group: 20130122

Customer Group or SDG Number:

Segment Portion: Tank Composite (Supernatant Liquid)

Parent Sample Number: S13T001225

\begin{tabular}{|c|c|c|c|c|c|c|c|c|c|c|c|c|c|}
\hline Sample\# $\quad R$ & \begin{tabular}{l|l} 
A\# & CAS \# \\
\end{tabular} & Analyte & Unit & STD \% & Blank & Result & Duplicate & Average & RPD \% & Spk Rec \% & Det Limit & Cnt Err \% & Qual Flags \\
\hline \multicolumn{14}{|c|}{ ICP-RCRA Metals } \\
\hline S13T001234 & $7782-49-2$ & Selenium & $\mathrm{ug} / \mathrm{mL}$ & 99.0 & $<6.00 \mathrm{E}-03$ & $<12.0$ & $\mathrm{n} / \mathrm{a}$ & $\mathrm{n} / \mathrm{a}$ & $n / a$ & $n / a$ & 12.0 & $\mathrm{n} / \mathrm{a}$ & u \\
\hline S13T00 1234 & $7440-21-3$ & Silicon & $\mathrm{ug} / \mathrm{mL}$ & 103 & $<5.00 E-03$ & 167 & $\mathrm{n} / \mathrm{a}$ & $\mathrm{n} / \mathrm{a}$ & $n / a$ & $n / a$ & 10.0 & $\mathrm{n} / \mathrm{a}$ & \\
\hline S13T00 1234 & $7440-24-6$ & Strontium & $\mathrm{ug} / \mathrm{mL}$ & 100 & $<2.00 \mathrm{E}-03$ & $<4.00$ & $\mathrm{n} / \mathrm{a}$ & $\mathrm{n} / \mathrm{a}$ & $n / a$ & $n / a$ & 4.00 & $\mathrm{n} / \mathrm{a}$ & u \\
\hline S13T001234 & $7440-32-6$ & Titanium & $\mathrm{ug} / \mathrm{mL}$ & 97.8 & $<1.00 \mathrm{E}-03$ & $<2.00$ & $\mathrm{n} / \mathrm{a}$ & $\mathrm{n} / \mathrm{a}$ & $n / a$ & $n / a$ & 2.00 & $\mathrm{n} / \mathrm{a}$ & u \\
\hline S13T00 1234 & $7440-28-0$ & Thallium & $\mathrm{ug} / \mathrm{mL}$ & 97.3 & $<6.00 \mathrm{E}-03$ & $<12.0$ & $n / a$ & $\mathrm{n} / \mathrm{a}$ & $n / a$ & $n / a$ & 12.0 & $n / a$ & u \\
\hline S13T001234 & $7440-68-6$ & Zinc & $\mathrm{ug} / \mathrm{mL}$ & 100 & $<4.00 \mathrm{E}-03$ & $<8.00$ & $\mathrm{n} / \mathrm{a}$ & $\mathrm{n} / \mathrm{a}$ & $n / a$ & $n / a$ & 8.00 & $\mathrm{n} / \mathrm{a}$ & u \\
\hline S13T001234 & $7440-67-7$ & Zirconium & $\mathrm{ug} / \mathrm{mL}$ & 98.2 & $<1.00 \mathrm{E}-03$ & $<2.00$ & $n / a$ & $\mathrm{n} / \mathrm{a}$ & $n / a$ & $n / a$ & 2.00 & $n / a$ & u \\
\hline \multicolumn{14}{|c|}{$\mathrm{OH}$ - by Pot. Titration } \\
\hline S13T001234 & HYDROXIDE & Hydroxide & $\mathrm{ug} / \mathrm{mL}$ & 88.8 & $<9.22$ & $1.50 \mathrm{E}+04$ & $\mathrm{n} / \mathrm{a}$ & $\mathrm{n} / \mathrm{a}$ & $n / a$ & $n / a$ & 553 & $\mathrm{n} / \mathrm{a}$ & \\
\hline \multicolumn{14}{|c|}{ TIC/TOC by Acid Persulfate } \\
\hline S13T001234 & TIC & Total inorganic carbon & $\mathrm{ug} / \mathrm{mL}$ & 101 & $<7.00$ & $7.60 \mathrm{E}+03$ & $\mathrm{n} / \mathrm{a}$ & n/a & $n / a$ & $n / a$ & 35.0 & $n / a$ & \\
\hline S13T001234 & TOC & Total organic carbon & $\mathrm{ug} / \mathrm{mL}$ & 89.1 & $<20.0$ & $1.60 \mathrm{E}+03$ & $\mathrm{n} / \mathrm{a}$ & $\mathrm{n} / \mathrm{a}$ & $\mathrm{n} / \mathrm{a}$ & $n / a$ & 100 & $\mathrm{n} / \mathrm{a}$ & \\
\hline
\end{tabular}

Parent Sample Number: S13T001226

\begin{tabular}{|c|c|c|c|c|c|c|c|c|c|c|c|c|c|c|}
\hline \begin{tabular}{|ll} 
Sample\# & R \\
\end{tabular} & A\# & CAS\# & Analyte & Unit & STD \% & Blank & Result & Duplicate & Average & RPD \% & Spk Rec \% & Det Limit & Cnt Err \% & Qual Flags \\
\hline \multicolumn{15}{|c|}{ Anions and Small Organic Acids } \\
\hline S13T001235 & & $16984-48-8$ & Fluoride & ug $/ \mathrm{mL}$ & 95.8 & $<1.61 \mathrm{E}-03$ & $1.90 \mathrm{E}+03$ & $\mathrm{n} / \mathrm{a}$ & $n / a$ & $n / a$ & $n / a$ & 24.2 & $n / a$ & \\
\hline S13T001235 & & 866-14-8 & Glycolate & $\mathrm{ug} / \mathrm{mL}$ & 95.4 & $<9.37 \mathrm{E}-03$ & 831 & $\mathrm{n} / \mathrm{a}$ & $\mathrm{n} / \mathrm{a}$ & $n / a$ & $\mathrm{n} / \mathrm{a}$ & 141 & $n / a$ & $\mathrm{~J}$ \\
\hline S13T001235 & & $71-50-1$ & Acetate & $\mathrm{ug} / \mathrm{mL}$ & 93.4 & $<6.04 \mathrm{E}-03$ & 894 & $n / a$ & $n / a$ & $\mathrm{n} / \mathrm{a}$ & $n / a$ & 90.6 & $n / a$ & $\mathrm{~J}$ \\
\hline S13T001235 & & $12311-97-6$ & Formate & $\mathrm{ug} / \mathrm{mL}$ & 97.2 & $<4.67 \mathrm{E}-03$ & $1.66 \mathrm{E}+03$ & $\mathrm{n} / \mathrm{a}$ & $n / a$ & $\mathrm{n} / \mathrm{a}$ & $n / a$ & 70.0 & $n / a$ & $\mathrm{~J}$ \\
\hline S13T001235 & & $16887-00-6$ & Chloride & $\mathrm{ug} / \mathrm{mL}$ & 96.3 & 0.0110 & $2.96 \mathrm{E}+03$ & $n / a$ & $n / a$ & $\mathrm{n} / \mathrm{a}$ & $n / a$ & 150 & $n / a$ & \\
\hline S13T001235 & & $14797-65-0$ & Nitrite & $\mathrm{ug} / \mathrm{mL}$ & 104 & $<0.0192$ & $6.16 \mathrm{E}+04$ & $\mathrm{n} / \mathrm{a}$ & $n / a$ & $n / a$ & $n / a$ & 288 & $n / a$ & \\
\hline S13T001235 & & $14808-79-8$ & Sulfate & $\mathrm{ug} / \mathrm{mL}$ & 96.2 & $<0.0187$ & $8.97 \mathrm{E}+03$ & $\mathrm{n} / \mathrm{a}$ & $n / a$ & $\mathrm{n} / \mathrm{a}$ & $n / a$ & 280 & $n / a$ & \\
\hline S13T001235 & & $338-70-5$ & Oxalate & $\mathrm{ug} / \mathrm{mL}$ & 97.4 & $<0.0231$ & 692 & $\mathrm{n} / \mathrm{a}$ & $n / a$ & $\mathrm{n} / \mathrm{a}$ & $n / a$ & 346 & $n / a$ & $\mathrm{~J}$ \\
\hline S13T001235 & & $24959-67-9$ & Bromide & $\mathrm{ug} / \mathrm{mL}$ & 97.2 & $<0.0580$ & $<870$ & $\mathrm{n} / \mathrm{a}$ & $\mathrm{n} / \mathrm{a}$ & $n / a$ & $\mathrm{n} / \mathrm{a}$ & 870 & & $u$ \\
\hline S13T001235 & & $14797-55-8$ & Nitrate & $\mathrm{ug} / \mathrm{mL}$ & 95.6 & $<0.0208$ & $2.20 \mathrm{E}+0.5$ & $\mathrm{n} / \mathrm{a}$ & $\mathrm{n} / \mathrm{a}$ & $n / a$ & $\mathrm{n} / \mathrm{a}$ & 312 & $\mathrm{n} / \mathrm{a}$ & \\
\hline S13T001235 & & $14265-44-2$ & Phosphate & ug $/ \mathrm{mL}$ & 96.8 & $<0.0167$ & $<250$ & $\mathrm{n} / \mathrm{a}$ & $n / a$ & $n / a$ & $\mathrm{n} / \mathrm{a}$ & 250 & $n / a$ & $u$ \\
\hline
\end{tabular}


Table D-1. Tank 241-AW-106 Boildown Chemical Analysis Results for all Submitted Liquid Samples (20 sheets)

AW106 BLDN 2013

Data Summary Report

Sample Group: 20130122

Customer Group or SDG Number:

Segment Portion: Tank Composite (Supernatant Liquid)

Parent Sample Number: S13T001226

\begin{tabular}{|c|c|c|c|c|c|c|c|c|c|c|c|c|c|c|}
\hline $\begin{array}{|ll|}\text { Sample\# } & \mathbf{R} \\
\end{array}$ & A\# & CAS \# & Analyte & Unit & STD \% & Blank & Result & Duplicate & Average & RPD \% & Spk Rec \% & Det Limit & Cnt Err \% & \begin{tabular}{|l} 
Qual Flags \\
\end{tabular} \\
\hline \multicolumn{15}{|l|}{ DENSITY } \\
\hline S13T00 1235 & & Density & Density & $\mathrm{g} / \mathrm{mL}$ & 99.42 & $n / a$ & 1.317 & $n / a$ & $n / a$ & $\mathrm{n} / \mathrm{a}$ & $n / a$ & $1.000 \mathrm{E}-03$ & $n / a$ & \\
\hline \multicolumn{15}{|c|}{ ICP-RCRA Metals } \\
\hline S13T00 1235 & & $7429-90-5$ & Aluminum & $\mathrm{ug} / \mathrm{mL}$ & 95.5 & $<6.00 \mathrm{E}-03$ & $7.85 \mathrm{E}+03$ & $\mathrm{n} / \mathrm{a}$ & $n / a$ & $\mathrm{n} / \mathrm{a}$ & $n / a$ & 12.0 & $n / a$ & \\
\hline S13T00 1235 & & $7440-38-2$ & Arsenic & $\mathrm{ug} / \mathrm{mL}$ & 99.2 & $<5.00 \mathrm{E}-03$ & $<10.0$ & $\mathrm{n} / \mathrm{a}$ & $n / a$ & $n / a$ & $n / a$ & 10.0 & $n / a$ & u \\
\hline S13T00 1235 & & $7440-39-3$ & Barium & $\mathrm{ug} / \mathrm{mL}$ & 101 & $<1.00 \mathrm{E}-03$ & $<2.00$ & $\mathrm{n} / \mathrm{a}$ & $n / a$ & $\mathrm{n} / \mathrm{a}$ & $n / a$ & 2.00 & $n / a$ & u \\
\hline S13T00 1235 & & $7440-41-7$ & Beryllium & ug $/ \mathrm{mL}$ & 102 & $<1.00 \mathrm{E}-03$ & $<2.00$ & $\mathrm{n} / \mathrm{a}$ & $n / a$ & $\mathrm{n} / \mathrm{a}$ & $n / a$ & 2.00 & $n / a$ & u \\
\hline S13T001235 & & $7440-70-2$ & Calcium & $\mathrm{ug} / \mathrm{mL}$ & 95.5 & $<0.0800$ & $<160$ & $\mathrm{n} / \mathrm{a}$ & $n / a$ & $n / a$ & $n / a$ & 160 & $n / a$ & u \\
\hline S13T001235 & & $7440-43-8$ & Cadmium & $\mathrm{ug} / \mathrm{mL}$ & 97.0 & $<1.00 \mathrm{E}-03$ & 2.81 & $\mathrm{n} / \mathrm{a}$ & $n / a$ & $n / a$ & $n / a$ & 2.00 & $n / a$ & $\mathrm{~J}$ \\
\hline S13T001235 & & $7440-47-3$ & Chromium & $\mathrm{ug} / \mathrm{mL}$ & 101 & $<1.00 \mathrm{E}-03$ & 656 & $\mathrm{n} / \mathrm{a}$ & $\mathrm{n} / \mathrm{a}$ & $\mathrm{n} / \mathrm{a}$ & $\mathrm{n} / \mathrm{a}$ & 2.00 & $\mathrm{n} / \mathrm{a}$ & \\
\hline S13T00 1235 & & $7440-53-1$ & Europium & $\mathrm{ug} / \mathrm{mL}$ & 100 & $<1.00 \mathrm{E}-03$ & $<2.00$ & $\mathrm{n} / \mathrm{a}$ & $n / a$ & $n / a$ & $n / a$ & 2.00 & $n / a$ & u \\
\hline S13T001235 & & $7439-89-6$ & Iron & $\mathrm{ug} / \mathrm{mL}$ & 103 & $<0.0100$ & 57.8 & $\mathrm{n} / \mathrm{a}$ & $n / a$ & $n / a$ & $n / a$ & 20.0 & $n / a$ & J \\
\hline S13T001235 & & $7440-09-7$ & Potassium & $\mathrm{ug} / \mathrm{mL}$ & 98.7 & $<0.0200$ & $5.76 \mathrm{E}+03$ & $n / a$ & $n / a$ & $n / a$ & $n / a$ & 40.0 & $n / a$ & \\
\hline S13T00 1235 & & $7439-91-0$ & Lanthanum & $\mathrm{ug} / \mathrm{mL}$ & 104 & $<1.00 \mathrm{E}-03$ & $<2.00$ & $\mathrm{n} / \mathrm{a}$ & $n / a$ & $n / a$ & $n / a$ & 2.00 & $n / a$ & u \\
\hline S13T00 1235 & & 7439-93-2 & Lithium & $u g / m L$ & 105 & $<1.00 \mathrm{E}-03$ & $<2.00$ & $\mathrm{n} / \mathrm{a}$ & $\mathrm{n} / \mathrm{a}$ & $\mathrm{n} / \mathrm{a}$ & $\mathrm{n} / \mathrm{a}$ & 2.00 & $\mathrm{n} / \mathrm{a}$ & $u$ \\
\hline S13T001235 & & 7439-98-7 & Molybdenum & $\mathrm{ug} / \mathrm{mL}$ & 96.0 & $<1.00 \mathrm{E}-03$ & 30.8 & $\mathrm{n} / \mathrm{a}$ & $n / a$ & $\mathrm{n} / \mathrm{a}$ & $\mathrm{n} / \mathrm{a}$ & 2.00 & $n / a$ & \\
\hline S13T001235 & & $7440-23-5$ & Sodium & ug $/ \mathrm{mL}$ & 96.0 & $<0.0400$ & $1.65 E+05$ & $\mathrm{n} / \mathrm{a}$ & $n / a$ & $\mathrm{n} / \mathrm{a}$ & $n / a$ & 80.0 & $n / a$ & \\
\hline S13T00 1235 & & $7440-02-0$ & Nickel & ug $/ \mathrm{mL}$ & 100 & $<1.00 \mathrm{E}-03$ & 26.5 & $\mathrm{n} / \mathrm{a}$ & $n / a$ & $\mathrm{n} / \mathrm{a}$ & $n / a$ & 2.00 & $n / a$ & \\
\hline S13T001235 & & $7723-14-0$ & Phosphorus & $\mathrm{ug} / \mathrm{mL}$ & 96.1 & $<3.00 \mathrm{E}-03$ & 391 & $\mathrm{n} / \mathrm{a}$ & $n / a$ & $n / a$ & $n / a$ & 6.00 & $n / a$ & \\
\hline S13T001235 & & $7439-92-1$ & Lead & $\mathrm{ug} / \mathrm{mL}$ & 104 & $<6.00 \mathrm{E}-03$ & $<12.0$ & $\mathrm{n} / \mathrm{a}$ & $n / a$ & $\mathrm{n} / \mathrm{a}$ & $n / a$ & 12.0 & $n / a$ & u \\
\hline S13T00 1235 & & 7704-34-8 & Sulfur & $\mathrm{ug} / \mathrm{mL}$ & 100 & $<5.00 \mathrm{E}-03$ & $2.81 \mathrm{E}+03$ & $\mathrm{n} / \mathrm{a}$ & $\mathrm{n} / \mathrm{a}$ & $\mathrm{n} / \mathrm{a}$ & $n / a$ & 10.0 & $n / a$ & \\
\hline S13T00 1235 & & $7782-49-2$ & Selenium & $\mathrm{ug} / \mathrm{mL}$ & 99.0 & $<6.00 \mathrm{E}-03$ & $<12.0$ & $\mathrm{n} / \mathrm{a}$ & $n / a$ & $n / a$ & $n / a$ & 12.0 & $n / a$ & u \\
\hline S13T00 1235 & & $7440-21-3$ & Silicon & $\mathrm{ug} / \mathrm{mL}$ & 103 & $<5.00 \mathrm{E}-03$ & 95.8 & $\mathrm{n} / \mathrm{a}$ & $n / a$ & $n / a$ & $\mathrm{n} / \mathrm{a}$ & 10.0 & $n / a$ & $\mathrm{~J}$ \\
\hline S13T00 1235 & & $7440-24-6$ & Strontium & $\mathrm{ug} / \mathrm{mL}$ & 100 & $<2.00 \mathrm{E}-03$ & $<4.00$ & $\mathrm{n} / \mathrm{a}$ & $n / a$ & $n / a$ & $n / a$ & 4.00 & $n / a$ & u \\
\hline S13T00 1235 & & $7440-32-6$ & Titanium & $\mathrm{ug} / \mathrm{mL}$ & 97.8 & $<1.00 \mathrm{E}-03$ & $<2.00$ & $\mathrm{n} / \mathrm{a}$ & $n / a$ & $n / a$ & $n / a$ & 2.00 & $n / a$ & u \\
\hline S13T001235 & & $7440-28-0$ & Thallium & $\mathrm{ug} / \mathrm{mL}$ & 97.3 & $<6.00 \mathrm{E}-03$ & $<12.0$ & $\mathrm{n} / \mathrm{a}$ & $\mathrm{n} / \mathrm{a}$ & $\mathrm{n} / \mathrm{a}$ & $\mathrm{n} / \mathrm{a}$ & 12.0 & $n / a$ & $u$ \\
\hline S13T00 1235 & & $7440-66-6$ & Zinc & $\mathrm{ug} / \mathrm{mL}$ & 100 & $<4.00 \mathrm{E}-03$ & $<8.00$ & $\mathrm{n} / \mathrm{a}$ & $n / a$ & $\mathrm{n} / \mathrm{a}$ & $n / a$ & 8.00 & $n / a$ & $u$ \\
\hline S13T00 1235 & & 7440-67-7 & Zirconium & $\mathrm{ug} / \mathrm{mL}$ & 98.2 & $<1.00 \mathrm{E}-03$ & $<2.00$ & $n / a$ & $\mathrm{n} / \mathrm{a}$ & $\mathrm{n} / \mathrm{a}$ & $n / a$ & 2.00 & $\mathrm{n} / \mathrm{a}$ & $u$ \\
\hline
\end{tabular}


Table D-1. Tank 241-AW-106 Boildown Chemical Analysis Results for all Submitted Liquid Samples (20 sheets)

AW106 BLDN 2013

Data Summary Report

Sample Group: 20130122

Customer Group or SDG Number:

Segment Portion: Tank Composite (Supernatant Liquid)

Parent Sample Number: S13T00122

\begin{tabular}{|c|c|c|c|c|c|c|c|c|c|c|c|c|c|c|}
\hline $\begin{array}{ll}\text { Sample\# } & \text { R } \\
\end{array}$ & A\# & CAS \# & Analyte & Unit & STD \% & Blank & \begin{tabular}{l|l} 
Result \\
\end{tabular} & \begin{tabular}{l|l} 
Duplicate \\
\end{tabular} & Average & RPD \% & Spk Rec \% & Det Limit & Cnt Err \% & Qual Flags \\
\hline S13T00 1235 & & HYDROXIDE & Hydroxide & $\mathrm{ug} / \mathrm{mL}$ & 88.8 & $<9.22$ & $1.58 \mathrm{E}+04$ & $\mathrm{n} / \mathrm{a}$ & $\mathrm{n} / \mathrm{a}$ & $\mathrm{n} / \mathrm{a}$ & $n / a$ & 553 & $n / a$ & \\
\hline \multicolumn{15}{|c|}{ TIC/TOC by Acid Persulfate } \\
\hline S13T001235 & & TIC & Total inorganic carbon & ug $/ \mathrm{mL}$ & 101 & $<7.00$ & $8.64 \mathrm{E}+03$ & $\mathrm{n} / \mathrm{a}$ & $\mathrm{n} / \mathrm{a}$ & $\mathrm{n} / \mathrm{a}$ & $\mathrm{n} / \mathrm{a}$ & 35.0 & $n / a$ & \\
\hline S13T001235 & & TOC & Total organic carbon & |ug/mL & 89.1 & $<20.0$ & $1.87 \mathrm{E}+03$ & $\mathrm{n} / \mathrm{a}$ & $\mathrm{n} / \mathrm{a}$ & $\mathrm{n} / \mathrm{a}$ & $\mathrm{n} / \mathrm{a}$ & 100 & $n / a$ & \\
\hline
\end{tabular}

Parent Sample Number: S13T001227

\begin{tabular}{|c|c|c|c|c|c|c|c|c|c|c|c|c|c|c|}
\hline Sample\# $\mathbf{R}$ & A\# & CAS \# & Analyte & Unit & STD \% & Blank & Result & Duplicate & Average & RPD \% & Spk Rec \% & Det Limit & Cnt Err \% & Qual Flags \\
\hline \multicolumn{15}{|c|}{ Anions and Small Organic Acids } \\
\hline S13T001236 & & $16984-48-8$ & Fluoride & $\mathrm{ug} / \mathrm{mL}$ & 95.8 & $<1.61 \mathrm{E}-03$ & $1.88 \mathrm{E}+03$ & $n / a$ & $n / a$ & $n / a$ & $n / a$ & 24.2 & $n / a$ & \\
\hline S13T001236 & & 666-14-8 & Glycolate & ug $/ \mathrm{mL}$ & 95.4 & $<9.37 \mathrm{E}-03$ & 821 & $n / a$ & $n / a$ & $\mathrm{n} / \mathrm{a}$ & $\mathrm{n} / \mathrm{a}$ & 141 & $n / a$ & $\mathrm{~J}$ \\
\hline S13T001236 & & $71-50-1$ & Acetate & ug $/ \mathrm{mL}$ & 93.4 & $<6.04 \mathrm{E}-03$ & 912 & $n / a$ & $n / a$ & $\mathrm{n} / \mathrm{a}$ & $n / a$ & 90.6 & $n / a$ & $J$ \\
\hline S13T001236 & & $12311-97-6$ & Formate & ug $/ \mathrm{mL}$ & 97.2 & $<4.67 \mathrm{E}-03$ & $1.69 \mathrm{E}+03$ & $\mathrm{n} / \mathrm{a}$ & $\mathrm{n} / \mathrm{a}$ & $\mathrm{n} / \mathrm{a}$ & $\mathrm{n} / \mathrm{a}$ & 70.0 & $\mathrm{n} / \mathrm{a}$ & $\mathrm{J}$ \\
\hline S13T001236 & & $16887-00-6$ & Chloride & $\mathrm{ug} / \mathrm{mL}$ & 96.3 & 0.0110 & $3.02 E+03$ & $\mathrm{n} / \mathrm{a}$ & $n / a$ & $\mathrm{n} / \mathrm{a}$ & $n / a$ & 150 & $n / a$ & \\
\hline S13T001236 & & $14797-65-0$ & Nitrite & ug $/ \mathrm{mL}$ & 104 & $<0.0192$ & $6.33 E+04$ & $n / a$ & $n / a$ & $\mathrm{n} / \mathrm{a}$ & $n / a$ & 288 & $n / a$ & \\
\hline S13T001236 & & $14808-79-8$ & Sulfate & ug $/ \mathrm{mL}$ & 96.2 & $<0.0187$ & $9.19 \mathrm{E}+03$ & $n / a$ & $n / a$ & $\mathrm{n} / \mathrm{a}$ & $n / a$ & 280 & $n / a$ & \\
\hline $\mathrm{S} 13 \mathrm{~T} 001236$ & & $338-70-5$ & Oxalate & ug $/ \mathrm{mL}$ & 97.4 & $<0.0231$ & 688 & $\mathrm{n} / \mathrm{a}$ & $n / a$ & $\mathrm{n} / \mathrm{a}$ & $\mathrm{n} / \mathrm{a}$ & 346 & $n / a$ & $J$ \\
\hline S13T001236 & & $24959-67-9$ & Bromide & ug $/ \mathrm{mL}$ & 97.2 & $<0.0580$ & $<870$ & $\mathrm{n} / \mathrm{a}$ & $n / a$ & $\mathrm{n} / \mathrm{a}$ & $\mathrm{n} / \mathrm{a}$ & 870 & $n / a$ & $u$ \\
\hline S13T001236 & & $14797-55-8$ & Nitrate & $\mathrm{ug} / \mathrm{mL}$ & 95.6 & $<0.0208$ & $2.26 \mathrm{E}+05$ & $n / a$ & $n / a$ & $n / a$ & $n / a$ & 312 & $n / a$ & \\
\hline S13T001236 & & $14265-44-2$ & Phosphate & ug $/ \mathrm{mL}$ & 98.8 & $<0.0167$ & $<250$ & $\mathrm{n} / \mathrm{a}$ & $\mathrm{n} / \mathrm{a}$ & $\mathrm{n} / \mathrm{a}$ & $n / a$ & 250 & & $u$ \\
\hline \multicolumn{15}{|l|}{ DENSITY } \\
\hline S13T001236 & & Density & Density & $g / \mathrm{mL}$ & 99.42 & $n / a$ & 1.336 & $\mathrm{n} / \mathrm{a}$ & $n / a$ & $\mathrm{n} / \mathrm{a}$ & $\mathrm{n} / \mathrm{a}$ & $1.000 \mathrm{E}-03$ & $n / a$ & \\
\hline \multicolumn{15}{|c|}{ ICP-RCRA Metals } \\
\hline S13T001236 & & $7429-90-5$ & Aluminum & $\mathrm{ug} / \mathrm{mL}$ & 95.5 & $<6.00 \mathrm{E}-03$ & $8.48 \mathrm{E}+03$ & $\mathrm{n} / \mathrm{a}$ & $\mathrm{n} / \mathrm{a}$ & $\mathrm{n} / \mathrm{a}$ & $\mathrm{n} / \mathrm{a}$ & 12.0 & $\mathrm{n} / \mathrm{a}$ & \\
\hline S13T001236 & & $7440-38-2$ & Arsenic & $\mathrm{ug} / \mathrm{mL}$ & 99.2 & $<5.00 \mathrm{E}-03$ & $<10.0$ & $\mathrm{n} / \mathrm{a}$ & $\mathrm{n} / \mathrm{a}$ & $\mathrm{n} / \mathrm{a}$ & $n / a$ & 10.0 & $n / a$ & $u$ \\
\hline S13T001236 & & $7440-39-3$ & Barium & ug $/ \mathrm{mL}$ & 101 & $<1.00 \mathrm{E}-03$ & $<2.00$ & $n / a$ & $n / a$ & $n / a$ & $n / a$ & 2.00 & $n / a$ & $u$ \\
\hline S13T00 1236 & & $7440-41-7$ & Beryllium & ug $/ \mathrm{mL}$ & 102 & $<1.00 \mathrm{E}-03$ & $<2.00$ & $n / a$ & $n / a$ & $\mathrm{n} / \mathrm{a}$ & $n / a$ & 2.00 & $n / a$ & $u$ \\
\hline S13T001236 & & $7440-70-2$ & Calcium & ug $/ \mathrm{mL}$ & 95.5 & $<0.0800$ & $<160$ & $\mathrm{n} / \mathrm{a}$ & $n / a$ & $n / a$ & $n / a$ & 160 & $n / a$ & $u$ \\
\hline S13T001236 & & $7440-43-9$ & Cadmium & $\mathrm{ug} / \mathrm{mL}$ & 97.0 & $<1.00 \mathrm{E}-03$ & 3.55 & $\mathrm{n} / \mathrm{a}$ & $\mathrm{n} / \mathrm{a}$ & $\mathrm{n} / \mathrm{a}$ & $\mathrm{n} / \mathrm{a}$ & 2.00 & $\mathrm{n} / \mathrm{a}$ & $\mathrm{J}$ \\
\hline S13T001236 & & $7440-47-3$ & Chromium & $\mathrm{ug} / \mathrm{mL}$ & 101 & $<1.00 \mathrm{E}-03$ & 707 & $\mathrm{n} / \mathrm{a}$ & $\mathrm{n} / \mathrm{a}$ & $\mathrm{n} / \mathrm{a}$ & $n / a$ & 2.00 & $n / a$ & \\
\hline
\end{tabular}


Table D-1. Tank 241-AW-106 Boildown Chemical Analysis Results for all Submitted Liquid Samples (20 sheets)

AW106 BLDN 2013

Data Summary Report

Sample Group: 20130122

Customer Group or SDG Number:

Segment Portion: Tank Composite (Supernatant Liquid)

Parent Sample Number: S13T001227

\begin{tabular}{|c|c|c|c|c|c|c|c|c|c|c|c|c|c|c|}
\hline $\begin{array}{ll}\text { Sample\# } & \mathbf{R}\end{array}$ & A\# & CAS\# & Analyte & Unit & STD \% & Blank & Result & Duplicate & Average & RPD \% & Spk Rec $\%$ & Det Limit & Cnt Err \% & Qual Flags \\
\hline \multicolumn{15}{|c|}{ ICP-RCRA Metals } \\
\hline $\mathrm{S} 13 \mathrm{~T} 001236$ & & $7440-53-1$ & Europium & $\mathrm{ug} / \mathrm{mL}$ & 100 & $<1.00 \mathrm{E}-03$ & $<2.00$ & $\mathrm{n} / \mathrm{a}$ & $\mathrm{n} / \mathrm{a}$ & $\mathrm{n} / \mathrm{a}$ & $\mathrm{n} / \mathrm{a}$ & 2.00 & $\mathrm{n} / \mathrm{a}$ & $u$ \\
\hline S13T001236 & & $7439-89-6$ & Iron & $\mathrm{ug} / \mathrm{mL}$ & 103 & $<0.0100$ & 83.0 & $n / a$ & $n / a$ & $n / a$ & $n / a$ & 20.0 & $n / a$. & $\mathrm{J}$ \\
\hline S13T001236 & & $7440-09-7$ & Potassium & $\mathrm{ug} / \mathrm{mL}$ & 98.7 & $<0.0200$ & $6.21 \mathrm{E}+03$ & $\mathrm{n} / \mathrm{a}$ & $\mathrm{n} / \mathrm{a}$ & $\mathrm{n} / \mathrm{a}$ & $n / a$ & 40.0 & $n / a$ & \\
\hline S13T001236 & & $7439-91-0$ & Lanthanum & $u g / m L$ & 104 & $<1.00 \mathrm{E}-03$ & $<2.00$ & $n / a$ & n/a & $\mathrm{n} / \mathrm{a}$ & $n / a$ & 2.00 & $\mathrm{n} / \mathrm{a}$ & $u$ \\
\hline S13T001236 & & $7439-93-2$ & Lithium & $u g / m L$ & 105 & $<1.00 \mathrm{E}-03$ & $<2.00$ & $n / a$ & $n / a$ & $\mathrm{n} / \mathrm{a}$ & $\mathrm{n} / \mathrm{a}$ & 2.00 & $\mathrm{n} / \mathrm{a}$ & $u$ \\
\hline S13T001236 & & $7439-98-7$ & Molybdenum & $\mathrm{ug} / \mathrm{mL}$ & 96.0 & $<1.00 \mathrm{E}-03$ & 32.8 & n/a & $\mathrm{n} / \mathrm{a}$ & $\mathrm{n} / \mathrm{a}$ & $\mathrm{n} / \mathrm{a}$ & 2.00 & $\mathrm{n} / \mathrm{a}$ & \\
\hline S13T001236 & & $7440-23-5$ & Sodium & $\mathrm{ug} / \mathrm{mL}$ & 96.0 & $<0.0400$ & $1.77 \mathrm{E}+05$ & $\mathrm{n} / \mathrm{a}$ & $n / a$ & $n / a$ & $n / a$ & 80.0 & $n / a$ & \\
\hline S13T001236 & & $7440-02-0$ & Nickel & $\mathrm{ug} / \mathrm{mL}$ & 100 & $<1.00 E-03$ & 28.4 & $n / a$ & $n / a$ & $n / a$ & $n / a$ & 2.00 & $n / a$ & \\
\hline S13T001236 & & $7723-14-0$ & Phosphorus & $\mathrm{ug} / \mathrm{mL}$ & 96.1 & $<3.00 \mathrm{E}-03$ & 332 & $n / a$ & $n / a$ & $n / a$ & $n / a$ & 6.00 & $n / a$ & \\
\hline $\mathrm{S} 13 \mathrm{~T} 001236$ & & $7439-92-1$ & Lead & $\mathrm{ug} / \mathrm{mL}$ & 104 & $<6.00 \mathrm{E}-03$ & $<12.0$ & $n / a$ & $\mathrm{n} / \mathrm{a}$ & $\mathrm{n} / \mathrm{a}$ & $n / a$ & 12.0 & $n / a$ & u \\
\hline S13T00 1236 & & $7704-34-9$ & Sulfur & $\mathrm{ug} / \mathrm{mL}$ & 100 & $<5.00 \mathrm{E}-03$ & $3.01 E+03$ & $\mathrm{n} / \mathrm{a}$ & $n / a$ & $\mathrm{n} / \mathrm{a}$ & $n / a$ & 10.0 & $\mathrm{n} / \mathrm{a}$ & \\
\hline S13T001236 & & $7782-49-2$ & Selenium & $\mathrm{ug} / \mathrm{mL}$ & 99.0 & $<6.00 \mathrm{E}-03$ & $<12.0$ & $\mathrm{n} / \mathrm{a}$ & $n / a$ & $\mathrm{n} / \mathrm{a}$ & $n / a$ & 12.0 & $\mathrm{n} / \mathrm{a}$ & $u$ \\
\hline S13T001236 & & $7440-21-3$ & Silicon & $u g / m L$ & 103 & $<5.00 \mathrm{E}-03$ & 77.0 & $n / a$ & $n / a$ & $\mathrm{n} / \mathrm{a}$ & $n / a$ & 10.0 & $\mathrm{n} / \mathrm{a}$ & $\mathrm{J}$ \\
\hline S13T001236 & & $7440-24-6$ & Strontium & $\mathrm{ug} / \mathrm{mL}$ & 100 & $<2.00 \mathrm{E}-03$ & $<4.00$ & $\mathrm{n} / \mathrm{a}$ & n/a & $n / a$ & $n / a$ & 4.00 & $n / a$ & $u$ \\
\hline S13T001236 & & $7440-32-6$ & Titanium & $\mathrm{ug} / \mathrm{mL}$ & 97.8 & $<1.00 \mathrm{E}-03$ & $<2.00$ & $n / a$ & $n / a$ & $\mathrm{n} / \mathrm{a}$ & $n / a$ & 2.00 & $\mathrm{n} / \mathrm{a}$ & u \\
\hline S13T001236 & & $7440-28-0$ & Thallium & $\mathrm{ug} / \mathrm{mL}$ & \begin{tabular}{l|l|}
97.3 \\
\end{tabular} & $<6.00 \mathrm{E}-03$ & $<12.0$ & $n / a$ & $n / a$ & $n / a$ & $n / a$ & 12.0 & $n / a$ & $u$ \\
\hline S13T001236 & & $7440-66-6$ & Zinc & $\mathrm{ug} / \mathrm{mL}$ & 100 & $<4.00 \mathrm{E}-03$ & $<8.00$ & $n / a$ & $n / a$ & $n / a$ & $\mathrm{n} / \mathrm{a}$ & 8.00 & $n / a$ & $u$ \\
\hline S13T001236 & & $7440-67-7$ & Zirconium & $\mathrm{ug} / \mathrm{mL}$ & 98.2 & $<1.00 \mathrm{E}-03$ & $<2.00$ & $n / a$ & $\mathrm{n} / \mathrm{a}$ & $n / a$ & $n / a$ & 2.00 & $n / a$ & $u$ \\
\hline \multicolumn{15}{|c|}{ OH- by Pot. Titration } \\
\hline $\mathrm{S} 13 \mathrm{~T} 001236$ & & HYDROXIDE & Hydroxide & $\mathrm{ug} / \mathrm{mL}$ & 88.8 & $<9.22$ & $1.77 \mathrm{E}+04$ & $\mathrm{n} / \mathrm{a}$ & $\mathrm{n} / \mathrm{a}$ & $\mathrm{n} / \mathrm{a}$ & $\mathrm{n} / \mathrm{a}$ & 553 & $\mathrm{n} / \mathrm{a}$ & \\
\hline \multicolumn{15}{|c|}{ TIC/TOC by Acid Persulfate } \\
\hline S13T001236 & & TIC & Total inorganic carbon & $\mathrm{ug} / \mathrm{mL}$ & 101 & $<7.00$ & $9.33 E+03$ & $\mathrm{n} / \mathrm{a}$ & $\mathrm{n} / \mathrm{a}$ & $n / a$ & $n / a$ & 70.0 & $n / a$ & \\
\hline S13T001236 & & TOC & Total organic carbon & $u g / \mathrm{mL}$ & 89.1 & $<20.0$ & $1.93 E+03$ & $n / a$ & $n / a$ & $\mathrm{n} / \mathrm{a}$ & $\mathrm{n} / \mathrm{a}$ & 200 & $\mathrm{n} / \mathrm{a}$ & \\
\hline
\end{tabular}

Parent Sample Number: S13T001228

\begin{tabular}{|c|c|c|c|c|c|c|c|c|c|c|c|c|c|c|c|}
\hline Sample\# & $R$ & A\# & CAS \# & Analyte & Unit & STD \% & Blank & Result & Duplicate & Average & RPD \% & Spk Rec \% & Det Limit & Cnt Err \% & Qual Flags \\
\hline \multicolumn{16}{|c|}{ Anions and Small Organic Acids } \\
\hline S13T00 12 & & & $16984-48-8$ & Fluoride & $\mathrm{ug} / \mathrm{mL}$ & 95.8 & $<1.61 \mathrm{E}-03$ & $1.97 \mathrm{E}+03$ & $\mathrm{n} / \mathrm{a}$ & $\mathrm{n} / \mathrm{a}$ & $\mathrm{n} / \mathrm{a}$ & $\mathrm{n} / \mathrm{a}$ & 24.2 & $n / a$ & \\
\hline
\end{tabular}


Table D-1. Tank 241-AW-106 Boildown Chemical Analysis Results for all Submitted Liquid Samples (20 sheets)

AW106 BLDN 2013

Data Summary Report

Sample Group: 20130122

Customer Group or SDG Number:

Segment Portion: Tank Composite (Supernatant Liquid)

Parent Sample Number: S13T001228

\begin{tabular}{|c|c|c|c|c|c|c|c|c|c|c|c|c|c|c|}
\hline \begin{tabular}{|ll} 
Sample\# & $\mathrm{R}$ \\
\end{tabular} & A\# & CAS\# & Analyte & Unit & STD \% & Blank & Result & Duplicate & Average & RPD \% & Spk Rec \% & Det Limit & Cnt Err \% & Qual Flags \\
\hline \multicolumn{15}{|c|}{ Anions and Small Organic Acids } \\
\hline S13T001237 & & 686-14-8 & Glycolate & $\mathrm{ug} / \mathrm{mL}$ & 95.4 & $<9.37 \mathrm{E}-03$ & 725 & $n / a$ & $\mathrm{n} / \mathrm{a}$ & $n / a$ & $n / a$ & 141 & $n / a$. & $\mathrm{J}$ \\
\hline S13T001237 & & $71-50-1$ & Acetate & $\mathrm{ug} / \mathrm{mL}$ & 93.4 & $<6.04 \mathrm{E}-03$ & $1.16 \mathrm{E}+03$ & $\mathrm{n} / \mathrm{a}$ & $n / a$ & $\mathrm{n} / \mathrm{a}$ & $\mathrm{n} / \mathrm{a}$ & 90.6 & $n / a$. & $\mathrm{J}$ \\
\hline S13T001237 & & $12311-97-6$ & Formate & $\mathrm{ug} / \mathrm{mL}$ & 97.2 & $<4.67 \mathrm{E}-03$ & $1.91 \mathrm{E}+03$ & $\mathrm{n} / \mathrm{a}$ & $\mathrm{n} / \mathrm{a}$ & $\mathrm{n} / \mathrm{a}$ & $\mathrm{n} / \mathrm{a}$ & 70.0 & $n / a$. & $\mathrm{J}$ \\
\hline S13T001237 & & $16887-00-6$ & Chloride & $\mathrm{ug} / \mathrm{mL}$ & 96.3 & 0.0110 & $3.32 \mathrm{E}+03$ & $\mathrm{n} / \mathrm{a}$ & $\mathrm{n} / \mathrm{a}$ & $\mathrm{n} / \mathrm{a}$ & $\mathrm{n} / \mathrm{a}$ & 150 & $\mathrm{n} / \mathrm{a}$ & \\
\hline S13T001237 & & $14797-65-0$ & Nitrite & $\mathrm{ug} / \mathrm{mL}$ & 104 & $<0.0192$ & $6.98 \mathrm{E}+04$ & $n / a$ & $\mathrm{n} / \mathrm{a}$ & $\mathrm{n} / \mathrm{a}$ & $n / a$ & 288 & $n / a$ & \\
\hline S13T001237 & & $14808-79-8$ & Sulfate & $\mathrm{ug} / \mathrm{mL}$ & 96.2 & $<0.0187$ & $9.95 \mathrm{E}+03$ & $\mathrm{n} / \mathrm{a}$ & $\mathrm{n} / \mathrm{a}$ & $\mathrm{n} / \mathrm{a}$ & $\mathrm{n} / \mathrm{a}$ & 280 & $n / a$ & \\
\hline S13T001237 & & $338-70-5$ & Oxalate & $\mathrm{ug} / \mathrm{mL}$ & 97.4 & $<0.0231$ & 972 & $n / a$ & $\mathrm{n} / \mathrm{a}$ & $\mathrm{n} / \mathrm{a}$ & $\mathrm{n} / \mathrm{a}$ & 346 & $\mathrm{n} / \mathrm{a}$. & $\mathrm{J}$ \\
\hline S13T001237 & & $24959-67-9$ & Bromide & $\mathrm{ug} / \mathrm{mL}$ & 97.2 & $<0.0580$ & $<870$ & $n / a$ & $\mathrm{n} / \mathrm{a}$ & $\mathrm{n} / \mathrm{a}$ & $n / a$ & 870 & $n / a$ & $u$ \\
\hline S13T001237 & & $14797-55-8$ & Nitrate & $u g / \mathrm{mL}$ & 95.6 & $<0.0208$ & $2.47 \mathrm{E}+05$ & $\mathrm{n} / \mathrm{a}$ & $\mathrm{n} / \mathrm{a}$ & $\mathrm{n} / \mathrm{a}$ & $\mathrm{n} / \mathrm{a}$ & 312 & $n / a$ & \\
\hline S13T001237 & & $14265-44-2$ & Phosphate & $u g / \mathrm{mL}$ & 96.8 & $<0.0167$ & $<250$ & $\mathrm{n} / \mathrm{a}$ & $n / a$ & $\mathrm{n} / \mathrm{a}$ & $\mathrm{n} / \mathrm{a}$ & 250 & $\mathrm{n} / \mathrm{a}$ & $\mathrm{u}$ \\
\hline \multicolumn{15}{|c|}{ DENSITY } \\
\hline S13T001237 & & Density & Density & $g / \mathrm{mL}$ & 99.42 & $\mathrm{n} / \mathrm{a}$ & 1.356 & n/a & $\mathrm{n} / \mathrm{a}$ & $\mathrm{n} / \mathrm{a}$ & $\mathrm{n} / \mathrm{a}$ & $1.000 \mathrm{E}-03$ & $n / a$ & \\
\hline \multicolumn{15}{|c|}{ ICP-RCRA Metals } \\
\hline S13T001237 & & $7429-90-5$ & Aluminum & $\mathrm{ug} / \mathrm{mL}$ & 95.5 & $<6.00 \mathrm{E}-03$ & $9.05 \mathrm{E}+03$ & $\mathrm{n} / \mathrm{a}$ & $n / a$ & $\mathrm{n} / \mathrm{a}$ & $\mathrm{n} / \mathrm{a}$ & 12.0 & $n / a$ & \\
\hline S13T001237 & & $7440-38-2$ & Arsenic & $\mathrm{ug} / \mathrm{mL}$ & 99.2 & $<5.00 \mathrm{E}-03$ & $<10.0$ & $n / a$ & $\mathrm{n} / \mathrm{a}$ & $\mathrm{n} / \mathrm{a}$ & $n / a$ & 10.0 & $n / a$ & u \\
\hline S13T001237 & & $7440-39-3$ & Barium & $\mathrm{ug} / \mathrm{mL}$ & 101 & $<1.00 \mathrm{E}-03$ & $<2.00$ & $n / a$ & $\mathrm{n} / \mathrm{a}$ & $\mathrm{n} / \mathrm{a}$ & $\mathrm{n} / \mathrm{a}$ & 2.00 & $n / a$ & $u$ \\
\hline S13T001237 & & $7440-41-7$ & Beryllium & $\mathrm{ug} / \mathrm{mL}$ & 102 & $<1.00 \mathrm{E}-03$ & $<2.00$ & $n / a$ & $\mathrm{n} / \mathrm{a}$ & $\mathrm{n} / \mathrm{a}$ & $n / a$ & 2.00 & $\mathrm{n} / \mathrm{a}$ & u \\
\hline S13T001237 & & $7440-70-2$ & Calcium & $\mathrm{ug} / \mathrm{mL}$ & 95.5 & $<0.0800$ & $<160$ & $n / a$ & $n / a$ & $\mathrm{n} / \mathrm{a}$ & $n / a$ & 160 & $\mathrm{n} / \mathrm{a}$ & $u$ \\
\hline S13T001237 & & $7440-43-8$ & Cadmium & $\mathrm{ug} / \mathrm{mL}$ & 97.0 & $<1.00 \mathrm{E}-03$ & 4.25 & $n / a$ & $n / a$ & $\mathrm{n} / \mathrm{a}$ & $\mathrm{n} / \mathrm{a}$ & 2.00 & $\mathrm{n} / \mathrm{a}$. & J \\
\hline S13T001237 & & $7440-47-3$ & Chromium & $\mathrm{ug} / \mathrm{mL}$ & 101 & $<1.00 E-03$ & 753 & $n / a$ & $\mathrm{n} / \mathrm{a}$ & $\mathrm{n} / \mathrm{a}$ & $\mathrm{n} / \mathrm{a}$ & 2.00 & $\mathrm{n} / \mathrm{a}$ & \\
\hline S13T001237 & & $7440-53-1$ & Europium & $\mathrm{ug} / \mathrm{mL}$ & 100 & $<1.00 E-03$ & $<2.00$ & $n / a$ & $\mathrm{n} / \mathrm{a}$ & $\mathrm{n} / \mathrm{a}$ & $\mathrm{n} / \mathrm{a}$ & 2.00 & $n / a$ & $u$ \\
\hline S13T001237 & & $7439-89-6$ & Iron & $\mathrm{ug} / \mathrm{mL}$ & 103 & $<0.0100$ & 64.5 & $n / a$ & $\mathrm{n} / \mathrm{a}$ & $\mathrm{n} / \mathrm{a}$ & $n / a$ & 20.0 & $\mathrm{n} / \mathrm{a}$ & J \\
\hline S13T001237 & & $7440-09-7$ & Potassium & $\mathrm{ug} / \mathrm{mL}$ & 98.7 & $<0.0200$ & $6.63 \mathrm{E}+03$ & $n / a$ & $\mathrm{n} / \mathrm{a}$ & $\mathrm{n} / \mathrm{a}$ & $\mathrm{n} / \mathrm{a}$ & 40.0 & $\mathrm{n} / \mathrm{a}$ & \\
\hline \begin{tabular}{|l|} 
S13T001237 \\
\end{tabular} & & 7439-91-0 & Lanthanum & $\mathrm{ug} / \mathrm{mL}$ & 104 & $<1.00 \mathrm{E}-03$ & $<2.00$ & $\mathrm{n} / \mathrm{a}$ & $\mathrm{n} / \mathrm{a}$ & $\mathrm{n} / \mathrm{a}$ & $n / a$ & 2.00 & $n / a$ & $u$ \\
\hline S13T001237 & & $7439-93-2$ & Lithium & ug/mL & 105 & $<1.00 \mathrm{E}-03$ & $<2.00$ & $n / a$ & $\mathrm{n} / \mathrm{a}$ & $\mathrm{n} / \mathrm{a}$ & $n / a$ & 2.00 & $\mathrm{n} / \mathrm{a}$ & $\mathrm{u}$ \\
\hline S13T001237 & & $7439-98-7$ & Molybdenum & $\mathrm{ug} / \mathrm{mL}$ & 96.0 & $<1.00 E-03$ & 34.6 & $n / a$ & $\mathrm{n} / \mathrm{a}$ & $\mathrm{n} / \mathrm{a}$ & $\mathrm{n} / \mathrm{a}$ & 2.00 & $\mathrm{n} / \mathrm{a}$ & \\
\hline S13T001237 & & $7440-23-5$ & Sodium & $\mathrm{ug} / \mathrm{mL}$ & 96.0 & $<0.0400$ & $1.88 \mathrm{E}+05$ & $n / a$ & $\mathrm{n} / \mathrm{a}$ & $\mathrm{n} / \mathrm{a}$ & $\mathrm{n} / \mathrm{a}$ & 80.0 & $\mathrm{n} / \mathrm{a}$ & \\
\hline
\end{tabular}


Table D-1. Tank 241-AW-106 Boildown Chemical Analysis Results for all Submitted Liquid Samples (20 sheets)

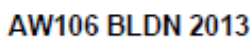

Data Summary Report

Sample Group: 20130122

Customer Group or SDG Number:

Segment Portion: Tank Composite (Supernatant Liquid)

Parent Sample Number: S13T001228

\begin{tabular}{|c|c|c|c|c|c|c|c|c|c|c|c|c|c|c|}
\hline Sample\# $\mathbf{R}$ & A\# & CAS\# & Analyte & Unit & STD \% & Blank & Result & Duplicate & Average & RPD \% & Spk Rec \% & Det Limit & Cnt Err \% & Qual Flags \\
\hline \multicolumn{15}{|c|}{ ICP-RCRA Metals } \\
\hline S13T001237 & & $7440-02-0$ & Nickel & $\mathrm{ug} / \mathrm{mL}$ & 100 & $<1.00 \mathrm{E}-03$ & 30.3 & $n / a$ & $n / a$ & $\mathrm{n} / \mathrm{a}$ & $n / a$ & 2.00 & $n / a$ & \\
\hline S13T001237 & & $7723-14-0$ & Phosphorus & $u g / m L$ & 96.1 & $<3.00 \mathrm{E}-03$ & 302 & $n / a$ & $n / a$ & $n / a$ & $n / a$ & 6.00 & $n / a$ & \\
\hline S13T00 1237 & & $7439-92-1$ & Lead & $u g / \mathrm{mL}$ & 104 & $<6.00 \mathrm{E}-03$ & $<12.0$ & $n / a$ & $n / a$ & $n / a$ & $\mathrm{n} / \mathrm{a}$ & 12.0 & $n / a$ & $u$ \\
\hline S13T00 1237 & & $7704-34-9$ & Sulfur & $\mathrm{ug} / \mathrm{mL}$ & 100 & $<5.00 \mathrm{E}-03$ & $3.08 \mathrm{E}+03$ & $n / a$ & $n / a$ & $\mathrm{n} / \mathrm{a}$ & $\mathrm{n} / \mathrm{a}$ & 10.0 & $n / a$ & \\
\hline S13T001237 & & $7782-49-2$ & Selenium & $\mathrm{ug} / \mathrm{mL}$ & 99.0 & $<6.00 \mathrm{E}-03$ & $<12.0$ & $\mathrm{n} / \mathrm{a}$ & $\mathrm{n} / \mathrm{a}$ & $\mathrm{n} / \mathrm{a}$ & $\mathrm{n} / \mathrm{a}$ & 12.0 & $n / a$ & $u$ \\
\hline S13T001237 & & $7440-21-3$ & Silicon & $\mathrm{ug} / \mathrm{mL}$ & 103 & $<5.00 \mathrm{E}-03$ & 84.2 & $\mathrm{n} / \mathrm{a}$ & $n / a$ & $n / a$ & $n / a$ & 10.0 & $n / a$. & $\mathrm{J}$ \\
\hline S13T001237 & & $7440-24-6$ & Strontium & $u g / \mathrm{mL}$ & 100 & $<2.00 \mathrm{E}-03$ & $<4.00$ & $n / a$ & $n / a$ & $n / a$ & $n / a$ & 4.00 & $n / a$ & $u$ \\
\hline S13T001237 & & $7440-32-6$ & Titanium & $\mathrm{ug} / \mathrm{mL}$ & 97.8 & $<1.00 E-03$ & $<2.00$ & $\mathrm{n} / \mathrm{a}$ & $\mathrm{n} / \mathrm{a}$ & $n / a$ & $\mathrm{n} / \mathrm{a}$ & 2.00 & $n / a$ & $u$ \\
\hline S13T001237 & & $7440-28-0$ & Thallium & $\mathrm{ug} / \mathrm{mL}$ & 97.3 & $<6.00 \mathrm{E}-03$ & $<12.0$ & $n / a$ & $n / a$ & $\mathrm{n} / \mathrm{a}$ & $\mathrm{n} / \mathrm{a}$ & 12.0 & $n / a$ & $u$ \\
\hline S13T001237 & & $7440-66-6$ & Zinc & $\mathrm{ug} / \mathrm{mL}$ & 100 & $<4.00 E-03$ & $<8.00$ & $\mathrm{n} / \mathrm{a}$ & $n / a$ & $n / a$ & $n / a$ & 8.00 & $n / a$ & $u$ \\
\hline S13T001237 & & $7440-67-7$ & Zirconium & $\mathrm{ug} / \mathrm{mL}$ & 98.2 & $<1.00 \mathrm{E}-03$ & 2.77 & $\mathrm{n} / \mathrm{a}$ & $n / a$ & $n / \mathrm{a}$ & $n / a$ & 2.00 & $n / \mathrm{a}$ & $\mathrm{J}$ \\
\hline \multicolumn{15}{|c|}{$\mathrm{OH}$ - by Pot. Titration } \\
\hline S13T001237 & & HYDROXIDE & Hydroxide & $\overline{u g} / \mathrm{mL}$ & 88.8 & $<9.22$ & $1.88 \mathrm{E}+04$ & $\mathrm{n} / \mathrm{a}$ & $\mathrm{n} / \mathrm{a}$ & $\mathrm{n} / \mathrm{a}$ & $n / a$ & 553 & $n / a$ & \\
\hline \multicolumn{15}{|c|}{ TIC/TOC by Acid Persulfate } \\
\hline S13T001237 & & TIC & Total inorganic carbon & $\mathrm{ug} / \mathrm{mL}$ & 101 & $<7.00$ & $1.06 \mathrm{E}+04$ & $n / a$ & $n / \mathrm{a}$ & $\mathrm{n} / \mathrm{a}$ & $\mathrm{n} / \mathrm{a}$ & 70.0 & $\mathrm{n} / \mathrm{a}$ & \\
\hline S13T001237 & & TOC & Total organic carbon & $u g / \mathrm{mL}$ & 89.1 & $<20.0$ & $2.26 \mathrm{E}+03$ & $n / a$ & $n / a$ & $n / a$ & $n / a$ & 200 & $n / a$ & \\
\hline
\end{tabular}

Parent Sample Number: S13T001229

\begin{tabular}{|c|c|c|c|c|c|c|c|c|c|c|c|c|c|c|}
\hline $\begin{array}{ll}\text { Sample\# } & \mathbf{R} \\
\end{array}$ & A\# & CAS\# & Analyte & Unit & STD \% & Blank & Result & Duplicate & Average & RPD \% & Spk Rec \% & Det Limit & Cnt Err \% & Qual Flags \\
\hline \multicolumn{15}{|c|}{ Anions and Small Organic Acids } \\
\hline S13T001238 & & $16984-48-8$ & Fluoride & ug $/ \mathrm{mL}$ & 95.8 & $<1.61 \mathrm{E}-03$ & 665 & $n / a$ & n/a & $\mathrm{n} / \mathrm{a}$ & $n / a$ & 24.2 & $n / a$ & \\
\hline S13T001238 & & $686-14-8$ & Glycolate & ug $/ \mathrm{mL}$ & 95.4 & $<9.37 \mathrm{E}-03$ & 790 & $n / a$ & $n / a$ & $\mathrm{n} / \mathrm{a}$ & $\mathrm{n} / \mathrm{a}$ & 141 & $n / a$ & 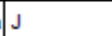 \\
\hline $\mathrm{S} 13 \mathrm{~T} 001238$ & & $71-50-1$ & Acetate & ug $/ \mathrm{mL}$ & 93.4 & $<6.04 \mathrm{E}-03$ & $1.02 E+03$ & $n / a$ & $n / a$ & $\mathrm{n} / \mathrm{a}$ & $n / a$ & 90.6 & $n / a$ & $\mathrm{~J}$ \\
\hline S13T001238 & & $12311-97-6$ & Formate & $\mathrm{ug} / \mathrm{mL}$ & 97.2 & $<4.67 \mathrm{E}-03$ & $1.87 \mathrm{E}+03$ & $\mathrm{n} / \mathrm{a}$ & $\mathrm{n} / \mathrm{a}$ & $\mathrm{n} / \mathrm{a}$ & $n / a$ & 70.0 & $\mathrm{n} / \mathrm{a}$ & $\mathrm{J}$ \\
\hline S13T001238 & & $16887-00-6$ & Chloride & $\mathrm{ug} / \mathrm{mL}$ & 96.3 & 0.0110 & $3.43 E+03$ & $n / a$ & $n / a$ & $n / a$ & $n / a$ & 150 & $\mathrm{n} / \mathrm{a}$ & \\
\hline S13T001238 & & $14797-65-0$ & Nitrite & $\mathrm{ug} / \mathrm{mL}$ & 104 & $<0.0192$ & $7.40 \mathrm{E}+04$ & $\mathrm{n} / \mathrm{a}$ & $\mathrm{n} / \mathrm{a}$ & $\mathrm{n} / \mathrm{a}$ & $\mathrm{n} / \mathrm{a}$ & 288 & $\mathrm{n} / \mathrm{a}$ & \\
\hline S13T001238 & & $14808-79-8$ & Sulfate & $\mathrm{ug} / \mathrm{mL}$ & 96.2 & $<0.0187$ & $3.67 \mathrm{E}+03$ & $n / a$ & $\mathrm{n} / \mathrm{a}$ & $\mathrm{n} / \mathrm{a}$ & $n / a$ & 280 & & $\mathrm{~J}$ \\
\hline S13T001238 & & $338-70-5$ & Oxalate & ug $/ \mathrm{mL}$ & 97.4 & $<0.0231$ & $<346$ & $n / a$ & $n / a$ & $n / a$ & $n / a$ & 346 & $\mathrm{n} / \mathrm{a}$ & $u$ \\
\hline
\end{tabular}


Table D-1. Tank 241-AW-106 Boildown Chemical Analysis Results for all Submitted Liquid Samples (20 sheets)

AW106 BLDN 2013

Data Summary Report

Sample Group: 20130122

Customer Group or SDG Number:

Segment Portion: Tank Composite (Supernatant Liquid)

Parent Sample Number: S13T001229

\begin{tabular}{|c|c|c|c|c|c|c|c|c|c|c|c|c|c|c|}
\hline $\begin{array}{ll}\text { Sample\# } & \mathbf{R} \\
\end{array}$ & A\# & CAS\# & Analyte & Unit & STD \% & Blank & Result & \begin{tabular}{l|l} 
Duplicate \\
\end{tabular} & Average & RPD \% & Spk Rec \% & Det Limit & Cnt Err \% & Qual Flags \\
\hline \multicolumn{15}{|c|}{ Anions and Small Organic Acids } \\
\hline $\mathrm{S} 13 \mathrm{~T} 001238$ & & $24959-67-9$ & Bromide & ug $/ \mathrm{mL}$ & 97.2 & $<0.0580$ & $<870$ & $\mathrm{n} / \mathrm{a}$ & $n / a$ & $n / a$ & $n / a$ & 870 & & $u$ \\
\hline S13T00 1238 & & $14797-55-8$ & Nitrate & $\mathrm{ug} / \mathrm{mL}$ & 95.6 & $<0.0208$ & $2.60 \mathrm{E}+05$ & $n / a$ & $n / a$ & $\mathrm{n} / \mathrm{a}$ & $n / a$ & 312 & $n / a$ & \\
\hline S13T00 1238 & & $14265-44-2$ & Phosphate & |ug/mL & 96.8 & $<0.0187$ & $<250$ & $n / a$ & $n / a$ & $\mathrm{n} / \mathrm{a}$ & $\mathrm{n} / \mathrm{a}$ & 250 & $n / a$ & $u$ \\
\hline \multicolumn{15}{|l|}{ DENSITY } \\
\hline S13T001238 & & Density & Density & $g / \mathrm{mL}$ & 99.42 & $n / a$ & 1.392 & $\mathrm{n} / \mathrm{a}$ & $n / \mathrm{a}$ & $n / a$ & $n / a$ & $1.000 \mathrm{E}-03$ & $\mathrm{n} / \mathrm{a}$ & \\
\hline \multicolumn{15}{|c|}{ ICP-RCRA Metals } \\
\hline S13T001238 & & $7429-90-5$ & Aluminum & ug/mL & 95.5 & $<6.00 \mathrm{E}-03$ & $9.82 \mathrm{E}+03$ & $\mathrm{n} / \mathrm{a}$ & $n / a$ & $\mathrm{n} / \mathrm{a}$ & $\mathrm{n} / \mathrm{a}$ & \begin{tabular}{l|l|}
12.0 \\
\end{tabular} & $\mathrm{n} / \mathrm{a}$ & \\
\hline S13T001238 & & $7440-38-2$ & Arsenic & $\mathrm{ug} / \mathrm{mL}$ & 99.2 & $<5.00 \mathrm{E}-03$ & $<10.0$ & $\mathrm{n} / \mathrm{a}$ & $\mathrm{n} / \mathrm{a}$ & $\mathrm{n} / \mathrm{a}$ & $n / a$ & 10.0 & $n / a$ & $u$ \\
\hline S13T001238 & & $7440-39-3$ & Barium & $\mathrm{ug} / \mathrm{mL}$ & 101 & $<1.00 E-03$ & $<2.00$ & $\mathrm{n} / \mathrm{a}$ & $\mathrm{n} / \mathrm{a}$ & $\mathrm{n} / \mathrm{a}$ & $n / a$ & 2.00 & $n / a$ & u \\
\hline S13T001238 & & $7440-41-7$ & Beryllium & $\mathrm{ug} / \mathrm{mL}$ & 102 & $<1.00 \mathrm{E}-03$ & $<2.00$ & $\mathrm{n} / \mathrm{a}$ & $n / a$ & $\mathrm{n} / \mathrm{a}$ & $n / a$ & 2.00 & $\mathrm{n} / \mathrm{a}$ & $u$ \\
\hline S13T001238 & & $7440-70-2$ & Calcium & $\mathrm{ug} / \mathrm{mL}$ & 95.5 & $<0.0800$ & $<160$ & $\mathrm{n} / \mathrm{a}$ & $n / a$ & $\mathrm{n} / \mathrm{a}$ & $\mathrm{n} / \mathrm{a}$ & 160 & $\mathrm{n} / \mathrm{a}$ & $u$ \\
\hline S13T001238 & & $7440-43-9$ & Cadmium & $\mathrm{ug} / \mathrm{mL}$ & 97.0 & $<1.00 E-03$ & \begin{tabular}{l|l}
4.15 \\
\end{tabular} & $n / a$ & $\mathrm{n} / \mathrm{a}$ & $n / a$ & $n / a$ & 2.00 & $\mathrm{n} / \mathrm{a}$ & $\mathrm{J}$ \\
\hline S13T001238 & & $7440-47-3$ & Chromium & $\mathrm{ug} / \mathrm{mL}$ & 101 & $<1.00 \mathrm{E}-03$ & 816 & $\mathrm{n} / \mathrm{a}$ & $n / a$ & $n / a$ & $n / a$ & 2.00 & $\mathrm{n} / \mathrm{a}$ & \\
\hline S13T001238 & & $7440-53-1$ & Europium & $\mathrm{ug} / \mathrm{mL}$ & 100 & $<1.00 \mathrm{E}-03$ & $<2.00$ & $n / a$ & $\mathrm{n} / \mathrm{a}$ & $\mathrm{n} / \mathrm{a}$ & $n / a$ & 2.00 & $n / a$ & $u$ \\
\hline S13T001238 & & $7439-89-6$ & Iron & $u g / m L$ & 103 & $<0.0100$ & 72.6 & $n / a$ & $n / a$ & $\mathrm{n} / \mathrm{a}$ & n/a & 20.0 & $n / a$ & $J$ \\
\hline S13T001238 & & $7440-09-7$ & Potassium & ug $/ \mathrm{mL}$ & 98.7 & $<0.0200$ & $7.18 \mathrm{E}+03$ & $\mathrm{n} / \mathrm{a}$ & $n / a$ & $n / a$ & $\mathrm{n} / \mathrm{a}$ & 40.0 & $n / a$ & \\
\hline $\mathrm{S} 13 \mathrm{~T} 001238$ & & $7439-91-0$ & Lanthanum & |ug $/ \mathrm{mL}$ & 104 & $<1.00 \mathrm{E}-03$ & $<2.00$ & $n / a$ & $n / a$ & $\mathrm{n} / \mathrm{a}$ & $\mathrm{n} / \mathrm{a}$ & 2.00 & $n / a$ & $u$ \\
\hline S13T001238 & & $7439-93-2$ & Lithium & $\mathrm{ug} / \mathrm{mL}$ & 105 & $<1.00 E-03$ & $<2.00$ & $\mathrm{n} / \mathrm{a}$ & $n / \mathrm{a}$ & $\mathrm{n} / \mathrm{a}$ & $n / a$ & 2.00 & $n / a$ & $u$ \\
\hline S13T001238 & & $7439-98-7$ & Molybdenum & $\mathrm{ug} / \mathrm{mL}$ & 96.0 & $<1.00 \mathrm{E}-03$ & 38.7 & $n / a$ & $\mathrm{n} / \mathrm{a}$ & $n / a$ & $n / a$ & 2.00 & $\mathrm{n} / \mathrm{a}$ & \\
\hline S13T001238 & & $7440-23-5$ & Sodium & $\mathrm{ug} / \mathrm{mL}$ & 96.0 & $<0.0400$ & $1.99 \mathrm{E}+05$ & $n / a$ & $\mathrm{n} / \mathrm{a}$ & $\mathrm{n} / \mathrm{a}$ & $n / a$ & 80.0 & $n / a$ & \\
\hline S13T001238 & & $7440-02-0$ & Nickel & $\mathrm{ug} / \mathrm{mL}$ & 100 & $<1.00 E-03$ & 31.8 & $\mathrm{n} / \mathrm{a}$ & $\mathrm{n} / \mathrm{a}$ & $\mathrm{n} / \mathrm{a}$ & $n / a$ & 2.00 & $n / a$ & \\
\hline S13T001238 & & $7723-14-0$ & Phosphorus & $\mathrm{ug} / \mathrm{mL}$ & 96.1 & $<3.00 \mathrm{E}-03$ & 297 & $n / a$ & $n / a$ & $n / a$ & $n / a$ & 6.00 & $n / a$ & \\
\hline S13T001238 & & $7439-92-1$ & Lead & ug $/ \mathrm{mL}$ & 104 & $<6.00 \mathrm{E}-03$ & 12.2 & $\mathrm{n} / \mathrm{a}$ & $n / a$ & $n / a$ & $n / a$ & 12.0 & $n / a$ & $J$ \\
\hline S13T001238 & & 7704-34-9 & Sulfur & ug/mL & 100 & $<5.00 \mathrm{E}-03$ & $1.19 \mathrm{E}+03$ & $\mathrm{n} / \mathrm{a}$ & $\mathrm{n} / \mathrm{a}$ & $\mathrm{n} / \mathrm{a}$ & $n / a$ & 10.0 & $n / a$ & \\
\hline S13T00 1238 & & $7782-49-2$ & Selenium & $\mathrm{ug} / \mathrm{mL}$ & 99.0 & $<6.00 \mathrm{E}-03$ & $<12.0$ & $\mathrm{n} / \mathrm{a}$ & $\mathrm{n} / \mathrm{a}$ & $\mathrm{n} / \mathrm{a}$ & $\mathrm{n} / \mathrm{a}$ & 12.0 & $\mathrm{n} / \mathrm{a}$ & u \\
\hline S13T00 1238 & & $7440-21-3$ & Silicon & $\mathrm{ug} / \mathrm{mL}$ & 103 & $<5.00 \mathrm{E}-03$ & 82.6 & $n / a$ & $n / a$ & $\mathrm{n} / \mathrm{a}$ & $n / a$ & 10.0 & $\mathrm{n} / \mathrm{a}$ & 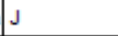 \\
\hline S13T001238 & & $7440-24-6$ & \begin{tabular}{|l} 
Strontium \\
\end{tabular} & ug $/ \mathrm{mL}$ & 100 & $<2.00 \mathrm{E}-03$ & $<4.00$ & $\mathrm{n} / \mathrm{a}$ & $n / a$ & $\mathrm{n} / \mathrm{a}$ & $\mathrm{n} / \mathrm{a}$ & 4.00 & $n / a$ & $u$ \\
\hline
\end{tabular}


Table D-1. Tank 241-AW-106 Boildown Chemical Analysis Results for all Submitted Liquid Samples (20 sheets)

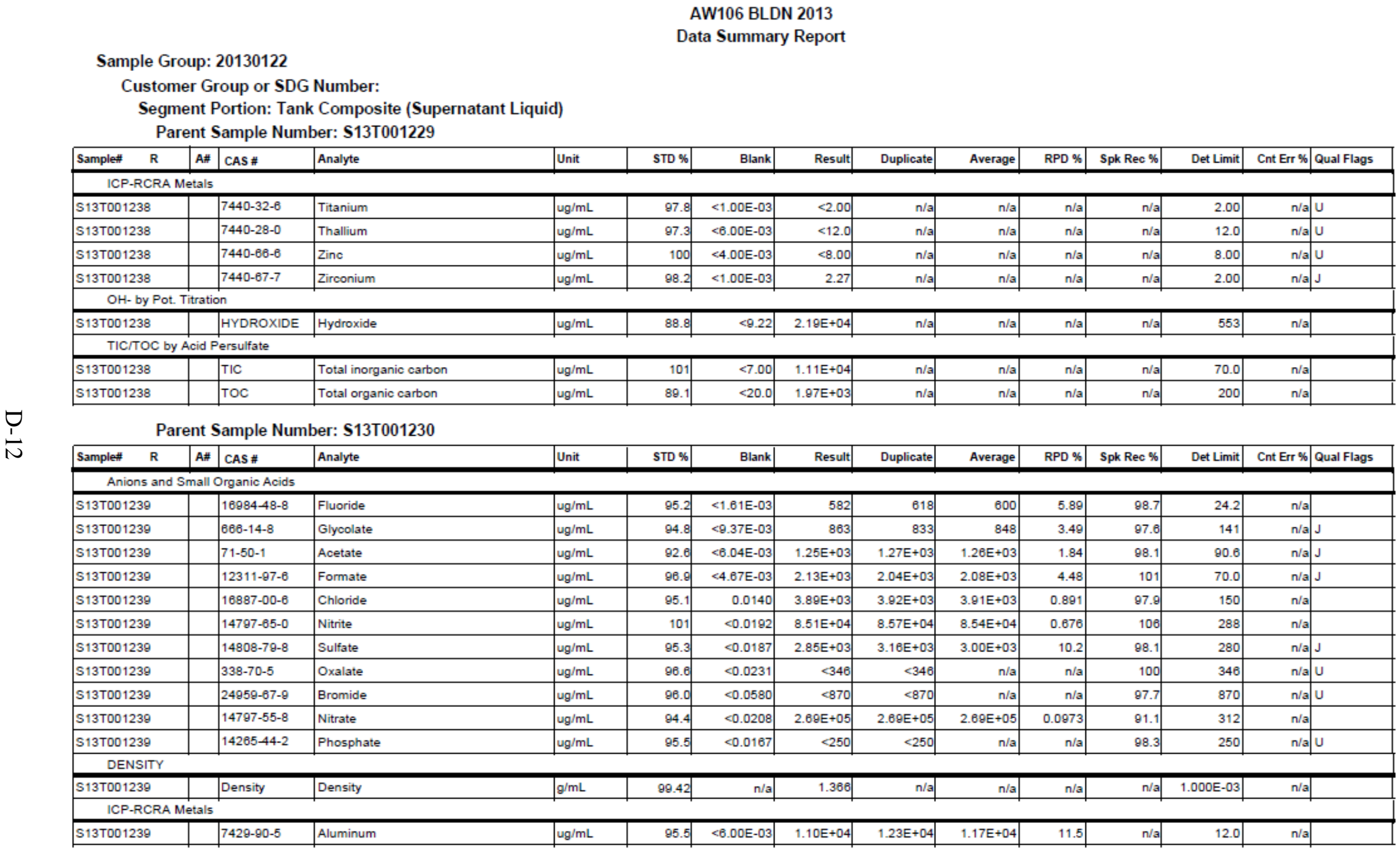


Table D-1. Tank 241-AW-106 Boildown Chemical Analysis Results for all Submitted Liquid Samples (20 sheets)

AW106 BLDN 2013

Data Summary Report

Sample Group: 20130122

Customer Group or SDG Number:

Segment Portion: Tank Composite (Supernatant Liquid)

Parent Sample Number: S13T001230

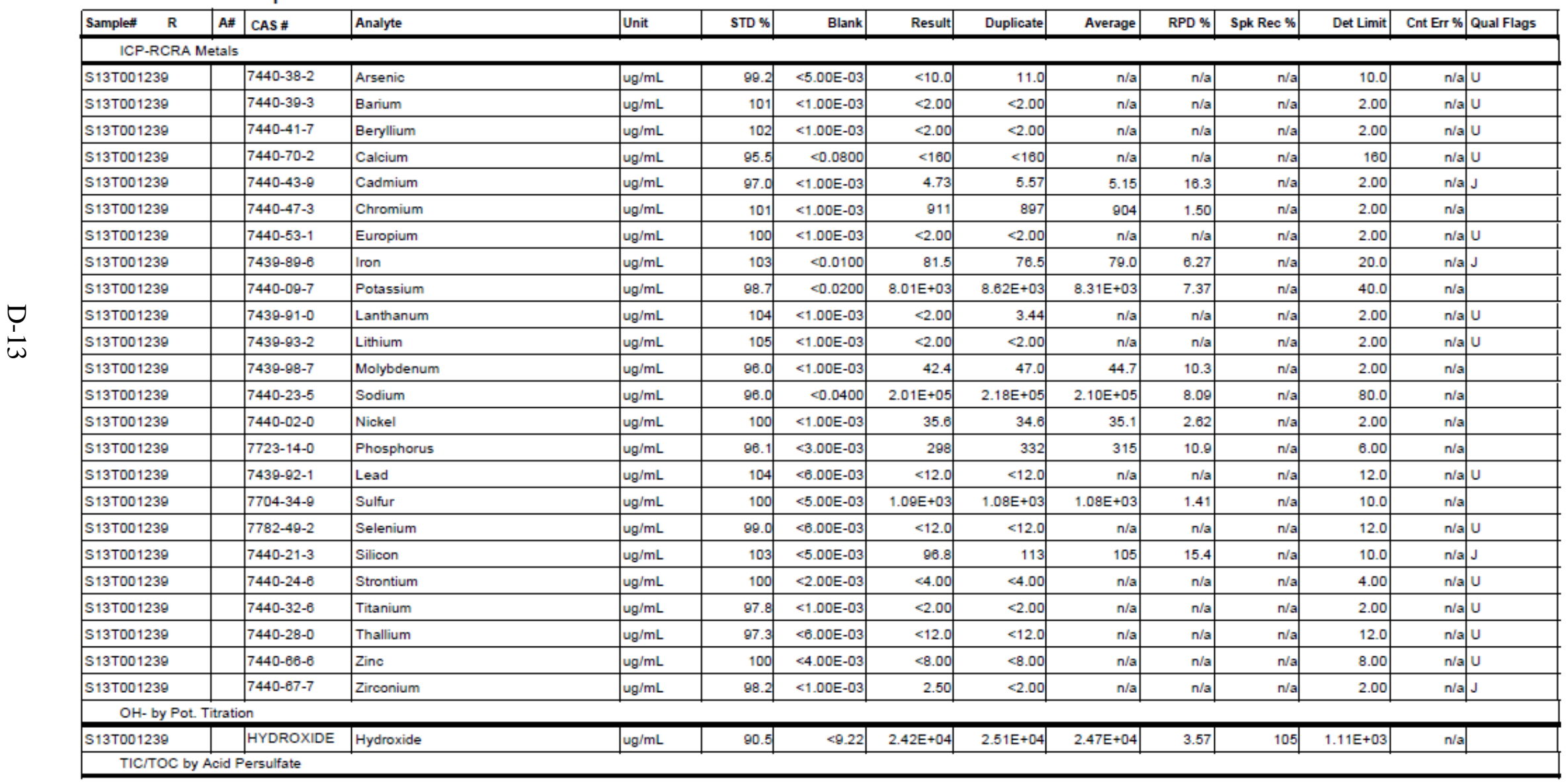


Table D-1. Tank 241-AW-106 Boildown Chemical Analysis Results for all Submitted Liquid Samples (20 sheets)

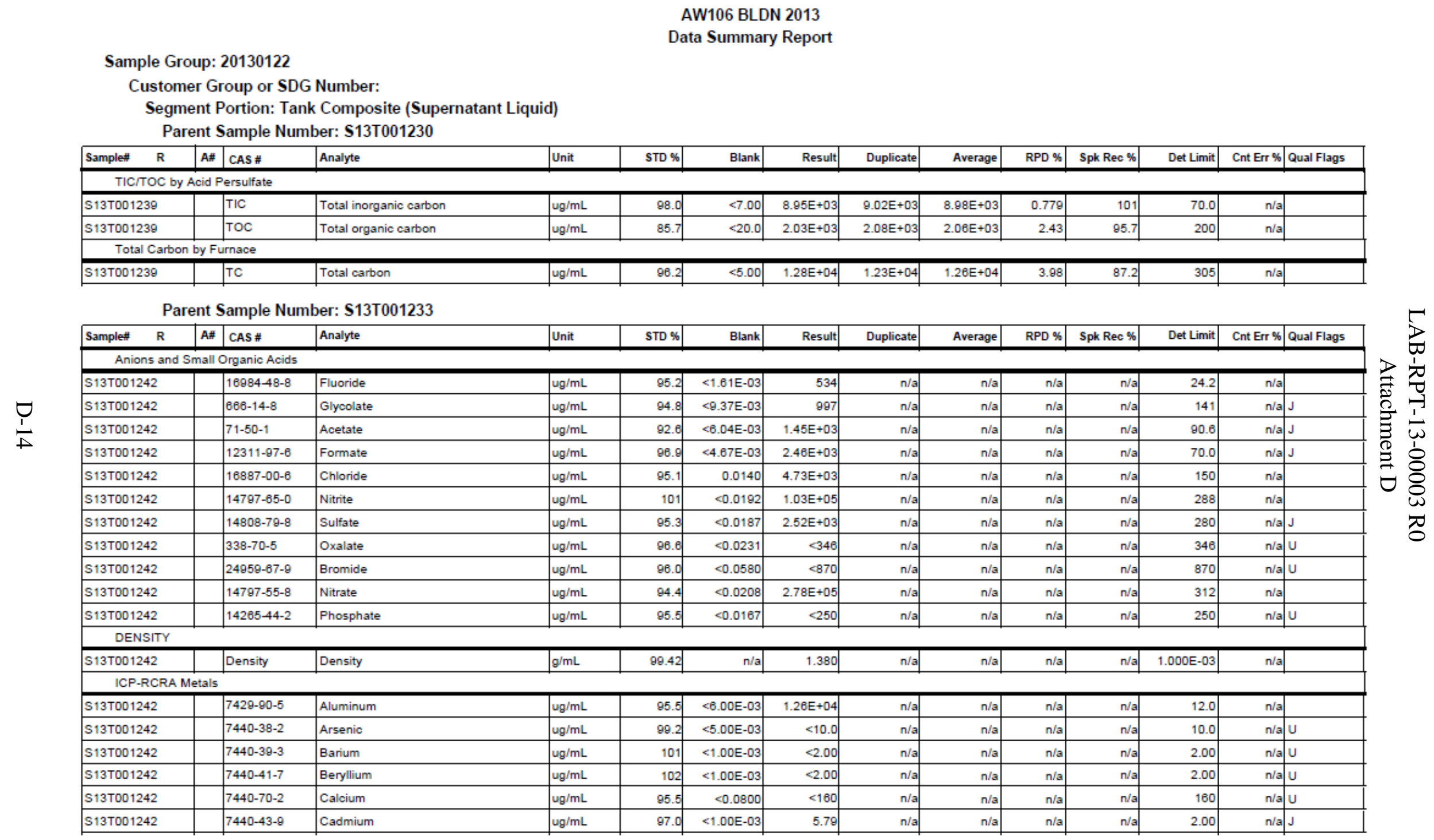


Table D-1. Tank 241-AW-106 Boildown Chemical Analysis Results for all Submitted Liquid Samples (20 sheets)

AW106 BLDN 2013

Data Summary Report

Sample Group: 20130122

Customer Group or SDG Number:

Segment Portion: Tank Composite (Supernatant Liquid)

Parent Sample Number: S13T001233

\begin{tabular}{|c|c|c|c|c|c|c|c|c|c|c|c|c|c|c|}
\hline Sample\# $\mathrm{R}$ & A\# & $\begin{array}{ll}\# \text { CAS \# } \\
\end{array}$ & Analyte & Unit & STD \% & Blank & Result & Duplicate & Average & RPD \% & Spk Rec \% & Det Limit & Cnt Err \% & Qual Flags \\
\hline \multicolumn{15}{|c|}{ ICP-RCRA Metals } \\
\hline S13T001242 & & $7440-47-3$ & Chromium & ug $/ \mathrm{mL}$ & 101 & $<1.00 \mathrm{E}-03$ & $1.05 E+03$ & $\mathrm{n} / \mathrm{a}$ & $\mathrm{n} / \mathrm{a}$ & $\mathrm{n} / \mathrm{a}$ & $n / a$ & 2.00 & $n / a$ & \\
\hline S13T001242 & & $7440-53-1$ & Europium & ug $/ \mathrm{mL}$ & 100 & $<1.00 \mathrm{E}-03$ & $<2.00$ & $n / a$ & $\mathrm{n} / \mathrm{a}$ & $\mathrm{n} / \mathrm{a}$ & $n / a$ & 2.00 & $n / a$ & $u$ \\
\hline S13T001242 & & $7439-89-6$ & Iron & |ug $/ \mathrm{mL}$ & 103 & $<0.0100$ & 95.6 & $\mathrm{n} / \mathrm{a}$ & $\mathrm{n} / \mathrm{a}$ & $\mathrm{n} / \mathrm{a}$ & $n / a$ & 20.0 & $n / a$ & $\mathrm{~J}$ \\
\hline S13T001242 & & $7440-09-7$ & Potassium & ug/mL & 98.7 & $<0.0200$ & $9.23 E+03$ & $n / a$ & $n / a$ & $\mathrm{n} / \mathrm{a}$ & $\mathrm{n} / \mathrm{a}$ & 40.0 & $n / a$ & \\
\hline S13T001242 & & $7439-81-0$ & Lanthanum & $\mathrm{ug} / \mathrm{mL}$ & 104 & $<1.00 \mathrm{E}-03$ & $<2.00$ & $n / a$ & $\mathrm{n} / \mathrm{a}$ & $\mathrm{n} / \mathrm{a}$ & $n / a$ & 2.00 & $n / a$ & u \\
\hline S13T001242 & & $7439-93-2$ & Lithium & $\mathrm{ug} / \mathrm{mL}$ & 105 & $<1.00 \mathrm{E}-03$ & $<2.00$ & $\mathrm{n} / \mathrm{a}$ & $n / a$ & $n / a$ & $n / a$ & 2.00 & $n / a$ & $u$ \\
\hline S13T001242 & & 7439-98-7 & Molybdenum & $\mathrm{ug} / \mathrm{mL}$ & 96.0 & $<1.00 \mathrm{E}-03$ & $\begin{array}{l}48.7 \\
\end{array}$ & $\mathrm{n} / \mathrm{a}$ & $\mathrm{n} / \mathrm{a}$ & $n / a$ & $n / a$ & 2.00 & $n / a$ & \\
\hline S13T001242 & & $7440-23-5$ & Sodium & $\mathrm{ug} / \mathrm{mL}$ & 96.0 & $<0.0400$ & $2.05 \mathrm{E}+05$ & $\mathrm{n} / \mathrm{a}$ & $\mathrm{n} / \mathrm{a}$ & $\mathrm{n} / \mathrm{a}$ & $n / a$ & 80.0 & $n / a$ & \\
\hline S13T001242 & & $7440-02-0$ & Nickel & ug $/ \mathrm{mL}$ & 100 & $<1.00 \mathrm{E}-03$ & 40.8 & $\mathrm{n} / \mathrm{a}$ & $\mathrm{n} / \mathrm{a}$ & $\mathrm{n} / \mathrm{a}$ & $n / a$ & 2.00 & $n / a$ & \\
\hline S13T001242 & & $7723-14-0$ & Phosphorus & $\mathrm{ug} / \mathrm{mL}$ & 96.1 & $<3.00 \mathrm{E}-03$ & 328 & $n / a$ & $n / a$ & $\mathrm{n} / \mathrm{a}$ & $n / a$ & 6.00 & $n / a$ & \\
\hline \begin{tabular}{|l|} 
S13T001242 \\
\end{tabular} & & $7439-92-1$ & Lead & $\mathrm{ug} / \mathrm{mL}$ & 104 & $<6.00 \mathrm{E}-03$ & $<12.0$ & $n / a$ & $n / a$ & $\mathrm{n} / \mathrm{a}$ & $n / a$ & 12.0 & $n / a$ & $u$ \\
\hline S13T001242 & & $7704-34-9$ & Sulfur & $\mathrm{ug} / \mathrm{mL}$ & 100 & $<5.00 \mathrm{E}-03$ & 981 & $\mathrm{n} / \mathrm{a}$ & $\mathrm{n} / \mathrm{a}$ & $\mathrm{n} / \mathrm{a}$ & $\mathrm{n} / \mathrm{a}$ & 10.0 & $n / a$ & \\
\hline S13T001242 & & $7782-49-2$ & Selenium & $\mathrm{ug} / \mathrm{mL}$ & 99.0 & $<6.00 \mathrm{E}-03$ & $<12.0$ & $\mathrm{n} / \mathrm{a}$ & $\mathrm{n} / \mathrm{a}$ & $\mathrm{n} / \mathrm{a}$ & $n / a$ & 12.0 & $n / a$ & $u$ \\
\hline S13T001242 & & $7440-21-3$ & Silicon & $\mathrm{ug} / \mathrm{mL}$ & 103 & $<5.00 \mathrm{E}-03$ & 111 & $n / a$ & $n / a$ & $n / a$ & $n / a$ & 10.0 & $n / a$ & \\
\hline S13T001242 & & $7440-24-6$ & Strontium & $\mathrm{ug} / \mathrm{mL}$ & 100 & $<2.00 \mathrm{E}-03$ & $<4.00$ & $n / a$ & $\mathrm{n} / \mathrm{a}$ & $n / a$ & $n / a$ & 4.00 & $n / a$ & $u$ \\
\hline S13T001242 & & $7440-32-6$ & Titanium & ug $/ \mathrm{mL}$ & 97.8 & $<1.00 \mathrm{E}-03$ & $<2.00$ & $\mathrm{n} / \mathrm{a}$ & $\mathrm{n} / \mathrm{a}$ & $\mathrm{n} / \mathrm{a}$ & $n / a$ & 2.00 & $n / a$ & $u$ \\
\hline S13T001242 & & $7440-28-0$ & Thallium & $\mathrm{ug} / \mathrm{mL}$ & 97.3 & $<6.00 \mathrm{E}-03$ & $<12.0$ & $\mathrm{n} / \mathrm{a}$ & $\mathrm{n} / \mathrm{a}$ & $\mathrm{n} / \mathrm{a}$ & $n / a$ & 12.0 & $n / a$ & $u$ \\
\hline S13TO0 1242 & & $7440-66-6$ & Zinc & $\mathrm{ug} / \mathrm{mL}$ & 100 & $<4.00 \mathrm{E}-03$ & $<8.00$ & $n / a$ & $\mathrm{n} / \mathrm{a}$ & $n / a$ & $n / a$ & 8.00 & $n / a$ & $u$ \\
\hline S13T001242 & & $7440-67-7$ & Zirconium & $\mathrm{ug} / \mathrm{mL}$ & 98.2 & $<1.00 \mathrm{E}-03$ & 2.68 & $\mathrm{n} / \mathrm{a}$ & $\mathrm{n} / \mathrm{a}$ & $n / a$ & $n / a$ & 2.00 & $n / a$. & $\mathrm{J}$ \\
\hline \multicolumn{15}{|c|}{$\mathrm{OH}$ - by Pot. Titration } \\
\hline S13T001242 & & HYDROXIDE & Hydroxide & $\mathrm{ug} / \mathrm{mL}$ & 88.8 & $<9.22$ & $2.94 \mathrm{E}+04$ & $\mathrm{n} / \mathrm{a}$ & $\mathrm{n} / \mathrm{a}$ & $n / a$ & $\mathrm{n} / \mathrm{a}$ & $1.11 \mathrm{E}+03$ & $n / a$ & \\
\hline \multicolumn{15}{|c|}{ TIC/TOC by Acid Persulfate } \\
\hline S13T001242 & & TIC & Total inorganic carbon & $\mathrm{ug} / \mathrm{mL}$ & 101 & $<7.00$ & $7.72 \mathrm{E}+03$ & $\mathrm{n} / \mathrm{a}$ & $\mathrm{n} / \mathrm{a}$ & $\mathrm{n} / \mathrm{a}$ & $\mathrm{n} / \mathrm{a}$ & 70.0 & $n / a$ & \\
\hline S13T001242 & & TOC & Total organic carbon & $\mathrm{ug} / \mathrm{mL}$ & 89.1 & $<20.0$ & $2.50 \mathrm{E}+03$ & $\mathrm{n} / \mathrm{a}$ & $\mathrm{n} / \mathrm{a}$ & n/a & $n / a \mid$ & 200 & $n / a \mid$ & \\
\hline \multicolumn{4}{|c|}{ Parent Sample Number: S13T001247 } & & & & & & & & & & & \\
\hline Sample\# & A\# & $\#$ CAS \# & Analyte & Unit & STD \% & Blank & Result & Duplicate & \begin{tabular}{|l|l|} 
Average & \\
\end{tabular} & RPD \% & Spk Rec \% & Det Limit & Cnt Err \% & Qual Flags \\
\hline
\end{tabular}


Table D-1. Tank 241-AW-106 Boildown Chemical Analysis Results for all Submitted Liquid Samples (20 sheets)

AW106 BLDN 2013

Data Summary Report

Sample Group: 20130122

Customer Group or SDG Number:

Segment Portion: Tank Composite (Supernatant Liquid)

Parent Sample Number: S13T001247

\begin{tabular}{|c|c|c|c|c|c|c|c|c|c|c|c|c|c|}
\hline \begin{tabular}{|ll} 
Sample\# & $\mathbf{R}$ \\
\end{tabular} & \begin{tabular}{|l|l|} 
A\# & CAS\# \\
\end{tabular} & Analyte & Unit & STD \% & Blank & Result & Duplicate & Average & RPD \% & Spk Rec \% & Det Limit & Cnt Err\% & Qual Flags \\
\hline \multicolumn{14}{|c|}{ Anions and Small Organic Acids } \\
\hline S13T001251 & $16984-48-8$ & Fluoride & $\mathrm{ug} / \mathrm{mL}$ & 95.2 & $<1.61 \mathrm{E}-03$ & 795 & $\mathrm{n} / \mathrm{a}$ & $n / a$ & $\mathrm{n} / \mathrm{a}$ & $\mathrm{n} / \mathrm{a}$ & 24.2 & $\mathrm{n} / \mathrm{a}$ & \\
\hline S13T00 1251 & $666-14-8$ & Glycolate & $\mathrm{ug} / \mathrm{mL}$ & 94.8 & $<9.37 \mathrm{E}-03$ & $<141$ & $\mathrm{n} / \mathrm{a}$ & $n / a$ & $\mathrm{n} / \mathrm{a}$ & $\mathrm{n} / \mathrm{a}$ & 141 & $n / a$ & $u$ \\
\hline S13T00 1251 & $71-50-1$ & Acetate & $\mathrm{ug} / \mathrm{mL}$ & 92.6 & $<6.04 \mathrm{E}-03$ & 815 & $n / a$ & $n / a$ & $n / a$ & $\mathrm{n} / \mathrm{a}$ & 90.6 & $n / a$ & $\mathrm{~J}$ \\
\hline S13T001251 & $12311-87-6$ & Formate & $\mathrm{ug} / \mathrm{mL}$ & 96.8 & $<4.67 \mathrm{E}-03$ & $1.75 \mathrm{E}+03$ & $n / a$ & $n / a$ & $n / a$ & $\mathrm{n} / \mathrm{a}$ & 70.0 & $n / a$ & $\mathrm{~J}$ \\
\hline S13T00 1251 & $16887-00-6$ & Chloride & $\mathrm{ug} / \mathrm{mL}$ & 95.1 & 0.0140 & $3.17 E+03$ & $\mathrm{n} / \mathrm{a}$ & $n / a$ & $\mathrm{n} / \mathrm{a}$ & $n / a$ & 150 & $\mathrm{n} / \mathrm{a}$ & \\
\hline S13T00 1251 & $14797-65-0$ & Nitrite & ug/mL & 101 & $<0.0192$ & $6.82 \mathrm{E}+04$ & $\mathrm{n} / \mathrm{a}$ & $n / a$ & $\mathrm{n} / \mathrm{a}$ & $\mathrm{n} / \mathrm{a}$ & 288 & $\mathrm{n} / \mathrm{a}$ & \\
\hline S13T00 1251 & $14808-79-8$ & Sulfate & $\mathrm{ug} / \mathrm{mL}$ & 95.3 & $<0.0187$ & $3.41 \mathrm{E}+03$ & $\mathrm{n} / \mathrm{a}$ & $n / a$ & $\mathrm{n} / \mathrm{a}$ & $\mathrm{n} / \mathrm{a}$ & 280 & $\mathrm{n} / \mathrm{a}$ & $\mathrm{J}$ \\
\hline S13T00 1251 & $338-70-5$ & Oxalate & $u g / m L$ & 96.6 & $<0.0231$ & $<346$ & $n / a$ & $n / a$ & $n / a$ & $n / a$ & 346 & $\mathrm{n} / \mathrm{a}$ & u \\
\hline S13T001251 & $24959-67-9$ & Bromide & ug $/ \mathrm{mL}$ & 96.0 & $<0.0580$ & $<870$ & $n / a$ & $n / a$ & $n / a$ & $n / a$ & 870 & $n / a$ & u \\
\hline S13T001251 & $14797-55-8$ & Nitrate & $u g / m L$ & 94.4 & $<0.0208$ & $2.41 \mathrm{E}+05$ & $\mathrm{n} / \mathrm{a}$ & $\mathrm{n} / \mathrm{a}$ & $\mathrm{n} / \mathrm{a}$ & $\mathrm{n} / \mathrm{a}$ & 312 & $n / a$ & \\
\hline S13T001251 & $14265-44-2$ & Phosphate & $\mathrm{ug} / \mathrm{mL}$ & 95.5 & $<0.0167$ & $<250$ & $n / a$ & $n / a$ & $n / a$ & $n / a$ & 250 & $n / a$ & u \\
\hline \multicolumn{14}{|l|}{ DENSITY } \\
\hline S13T001251 & Density & Density & $\mathrm{g} / \mathrm{mL}$ & 99.42 & $\mathrm{n} / \mathrm{a}$ & 1.347 & $\mathrm{n} / \mathrm{a}$ & $\mathrm{n} / \mathrm{a}$ & $\mathrm{n} / \mathrm{a}$ & $\mathrm{n} / \mathrm{a}$ & $1.000 \mathrm{E}-03$ & $n / a$ & \\
\hline \multicolumn{14}{|c|}{ ICP-RCRA Metals } \\
\hline S13T001251 & $7429-90-5$ & Aluminum & $u g / m L$ & 95.5 & $<6.00 \mathrm{E}-03$ & $9.18 \mathrm{E}+03$ & $\mathrm{n} / \mathrm{a}$ & $\mathrm{n} / \mathrm{a}$ & $\mathrm{n} / \mathrm{a}$ & $\mathrm{n} / \mathrm{a}$ & 12.0 & $n / a$ & \\
\hline S13T00 1251 & $7440-38-2$ & Arsenic & $\mathrm{ug} / \mathrm{mL}$ & 99.2 & $<5.00 \mathrm{E}-03$ & $<10.0$ & $\mathrm{n} / \mathrm{a}$ & $n / a$ & $n / a$ & $\mathrm{n} / \mathrm{a}$ & 10.0 & $\mathrm{n} / \mathrm{a}$ & $\mathrm{u}$ \\
\hline S13T00 1251 & $7440-39-3$ & Barium & $\mathrm{ug} / \mathrm{mL}$ & 101 & $<1.00 \mathrm{E}-03$ & $<2.00$ & $\mathrm{n} / \mathrm{a}$ & $n / a$ & $\mathrm{n} / \mathrm{a}$ & $\mathrm{n} / \mathrm{a}$ & 2.00 & $\mathrm{n} / \mathrm{a}$ & $\mathrm{u}$ \\
\hline S13T00 1251 & $7440-41-7$ & Beryllium & $\mathrm{ug} / \mathrm{mL}$ & 102 & $<1.00 \mathrm{E}-03$ & $<2.00$ & $\mathrm{n} / \mathrm{a}$ & $n / a$ & $n / a$ & $n / a$ & 2.00 & $n / a$ & u \\
\hline S13T001251 & $7440-70-2$ & Calcium & ug $/ \mathrm{mL}$ & 95.5 & $<0.0800$ & $<160$ & $n / a$ & $n / a$ & $n / a$ & $n / a$ & 160 & $n / a$ & u \\
\hline S13T001251 & $7440-43-9$ & Cadmium & $\mathrm{ug} / \mathrm{mL}$ & 97.0 & $<1.00 \mathrm{E}-03$ & 4.25 & $\mathrm{n} / \mathrm{a}$ & $n / a$ & $\mathrm{n} / \mathrm{a}$ & $n / a$ & 2.00 & $n / a$ & $\mathrm{~J}$ \\
\hline S13T001251 & $7440-47-3$ & Chromium & $\mathrm{ug} / \mathrm{mL}$ & 101 & $<1.00 \mathrm{E}-03$ & 771 & $\mathrm{n} / \mathrm{a}$ & $n / a$ & $\mathrm{n} / \mathrm{a}$ & $n / a$ & 2.00 & $n / a$ & \\
\hline S13T001251 & $7440-53-1$ & Europium & $\mathrm{ug} / \mathrm{mL}$ & 100 & $<1.00 \mathrm{E}-03$ & $<2.00$ & $\mathrm{n} / \mathrm{a}$ & $\mathrm{n} / \mathrm{a}$ & $\mathrm{n} / \mathrm{a}$ & $\mathrm{n} / \mathrm{a}$ & 2.00 & $n / a$ & $\mathrm{u}$ \\
\hline S13T001251 & $7439-89-6$ & Iron & $u g / m L$ & 103 & $<0.0100$ & 67.7 & $\mathrm{n} / \mathrm{a}$ & $\mathrm{n} / \mathrm{a}$ & $\mathrm{n} / \mathrm{a}$ & $\mathrm{n} / \mathrm{a}$ & 20.0 & $n / a$ & $\mathrm{~J}$ \\
\hline S13T001251 & $7440-09-7$ & Potassium & $u g / \mathrm{mL}$ & 98.7 & $<0.0200$ & $6.72 \mathrm{E}+03$ & $\mathrm{n} / \mathrm{a}$ & $\mathrm{n} / \mathrm{a}$ & $\mathrm{n} / \mathrm{a}$ & $\mathrm{n} / \mathrm{a}$ & 40.0 & $n / a$ & \\
\hline S13T001251 & 7439-91-0 & Lanthanum & $u g / m L$ & 104 & $<1.00 \mathrm{E}-03$ & $<2.00$ & $\mathrm{n} / \mathrm{a}$ & $\mathrm{n} / \mathrm{a}$ & $\mathrm{n} / \mathrm{a}$ & $\mathrm{n} / \mathrm{a}$ & 2.00 & $\mathrm{n} / \mathrm{a}$ & $u$ \\
\hline S13T001251 & $7439-93-2$ & Lithium & $\mathrm{ug} / \mathrm{mL}$ & 105 & $<1.00 \mathrm{E}-03$ & $<2.00$ & $n / a$ & $n / a$ & $n / a$ & $n / a$ & 2.00 & $n / a$ & u \\
\hline S13T001251 & $7439-98-7$ & Molybdenum & $\mathrm{ug} / \mathrm{mL}$ & 96.0 & $<1.00 E-03$ & 36.7 & $\mathrm{n} / \mathrm{a}$ & $\mathrm{n} / \mathrm{a}$ & $\mathrm{n} / \mathrm{a}$ & $\mathrm{n} / \mathrm{a}$ & 2.00 & $n / a$ & \\
\hline
\end{tabular}


Table D-1. Tank 241-AW-106 Boildown Chemical Analysis Results for all Submitted Liquid Samples (20 sheets)

AW106 BLDN 2013

Data Summary Report

Sample Group: 20130122

Customer Group or SDG Number:

Segment Portion: Tank Composite (Supernatant Liquid)

Parent Sample Number: S13T001247

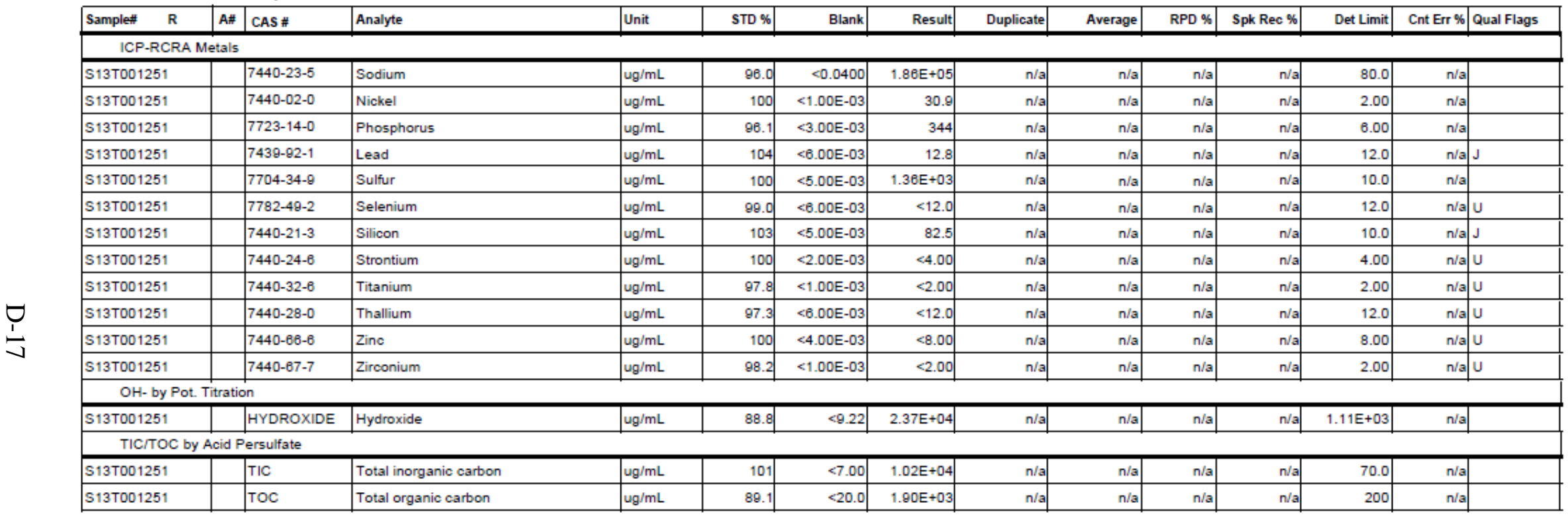

Parent Sample Number: S13T001248

\begin{tabular}{|c|c|c|c|c|c|c|c|c|c|c|c|c|c|c|}
\hline \begin{tabular}{|ll} 
Sample\# & R \\
\end{tabular} & A\# & CAS \# & Analyte & Unit & STD \% & Blank & Result & Duplicate & Average & RPD \% & Spk Rec \% & Det Limit & Cnt Err \% & Qual Flags \\
\hline \multicolumn{15}{|c|}{ Anions and Small Organic Acids } \\
\hline S13T001252 & & $16984-48-8$ & Fluoride & $\mathrm{ug} / \mathrm{mL}$ & 95.2 & $<1.61 \mathrm{E}-03$ & $1.05 \mathrm{E}+03$ & $\mathrm{n} / \mathrm{a}$ & $n / a$ & $\mathrm{n} / \mathrm{a}$ & $\mathrm{n} / \mathrm{a}$ & 24.2 & $n / a$ & \\
\hline S13T001252 & & 666-14-8 & Glycolate & $\mathrm{ug} / \mathrm{mL}$ & 94.8 & $<9.37 \mathrm{E}-03$ & 665 & $\mathrm{n} / \mathrm{a}$ & $n / a$ & $\mathrm{n} / \mathrm{a}$ & $n / a$ & 141 & $n / a$ & $\mathrm{~J}$ \\
\hline S13T00 1252 & & $71-50-1$ & Acetate & $\mathrm{ug} / \mathrm{mL}$ & 92.8 & $<6.04 \mathrm{E}-03$ & 922 & $\mathrm{n} / \mathrm{a}$ & $\mathrm{n} / \mathrm{a}$ & $\mathrm{n} / \mathrm{a}$ & $\mathrm{n} / \mathrm{a}$ & 90.6 & $n / a$ & 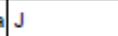 \\
\hline S13T001252 & & $12311-97-6$ & Formate & $u g / m L$ & 96.8 & $<4.67 \mathrm{E}-03$ & $1.55 \mathrm{E}+03$ & $n / a$ & $\mathrm{n} / \mathrm{a}$ & $\mathrm{n} / \mathrm{a}$ & $n / a$ & 70.0 & $n / a$ & $\mathrm{~J}$ \\
\hline S13T001252 & & $16887-00-6$ & Chloride & ug/mL & 95.1 & 0.0140 & $2.41 \mathrm{E}+03$ & $n / a$ & $n / a$ & $\mathrm{n} / \mathrm{a}$ & $\mathrm{n} / \mathrm{a}$ & 150 & $n / a$ & \\
\hline S13T00 1252 & & $14797-65-0$ & Nitrite & $u g / \mathrm{mL}$ & 101 & $<0.0192$ & $5.28 \mathrm{E}+04$ & $n / a$ & $n / a$ & $n / a$ & $n / a$ & 288 & $n / a$ & \\
\hline S13T001252 & & $14808-79-8$ & Sulfate & $u g / m L$ & 95.3 & $<0.0187$ & $5.00 \mathrm{E}+03$ & $n / a$ & $\mathrm{n} / \mathrm{a}$ & $n / a$ & $n / a$ & 280 & $n / a$ & \\
\hline
\end{tabular}


Table D-1. Tank 241-AW-106 Boildown Chemical Analysis Results for all Submitted Liquid Samples (20 sheets)

AW106 BLDN 2013

Data Summary Report

Sample Group: 20130122

Customer Group or SDG Number:

Segment Portion: Tank Composite (Supernatant Liquid)

Parent Sample Number: S13T001248

\begin{tabular}{|c|c|c|c|c|c|c|c|c|c|c|c|c|c|c|}
\hline Sample\# $\mathbf{R}$ & A\# & CAS\# & Analyte & Unit & STD \% & Blank & Result & Duplicate & Average & RPD \% & Spk Rec \% & Det Limit & Cnt Err \% & Qual Flags \\
\hline \multicolumn{15}{|c|}{ Anions and Small Organic Acids } \\
\hline S13T001252 & & $338-70-5$ & Oxalate & $\mathrm{ug} / \mathrm{mL}$ & 96.6 & $<0.0231$ & $<346$ & $\mathrm{n} / \mathrm{a}$ & $\mathrm{n} / \mathrm{a}$ & $n / a$ & $n / a$ & 346 & $n / a$ & $u$ \\
\hline S13T001252 & & $24959-67-9$ & Bromide & $\mathrm{ug} / \mathrm{mL}$ & 96.0 & $<0.0580$ & $<870$ & $n / a$ & $n / a$ & $n / a$ & $n / a$ & 870 & $n / a$ & $u$ \\
\hline S13T001252 & & $14797-55-8$ & Nitrate & $\mathrm{ug} / \mathrm{mL}$ & 94.4 & $<0.0208$ & $1.87 E+05$ & $\mathrm{n} / \mathrm{a}$ & $\mathrm{n} / \mathrm{a}$ & $n / a$ & $n / a$ & 312 & $n / a$ & \\
\hline $\mathrm{S} 13 \mathrm{~T} 001252$ & & $14265-44-2$ & Phosphate & $\mathrm{ug} / \mathrm{mL}$ & 95.5 & $<0.0187$ & $<250$ & $\mathrm{n} / \mathrm{a}$ & $\mathrm{n} / \mathrm{a}$ & n/a & $n / a$ & 250 & $n / a$ & u \\
\hline \multicolumn{15}{|l|}{ DENSITY } \\
\hline S13T001252 & & Density & Density & $\mathrm{g} / \mathrm{mL}$ & 99.42 & $\mathrm{n} / \mathrm{a}$ & 1.313 & $n / a$ & $\mathrm{n} / \mathrm{a}$ & $n / a$ & $\mathrm{n} / \mathrm{a}$ & $1.000 \mathrm{E}-03$ & $n / a$ & \\
\hline \multicolumn{15}{|c|}{ ICP-RCRA Metals } \\
\hline S13T001252 & & $7429-90-5$ & Aluminum & $\mathrm{ug} / \mathrm{mL}$ & 95.5 & $<6.00 \mathrm{E}-03$ & $8.03 E+03$ & $\mathrm{n} / \mathrm{a}$ & $\mathrm{n} / \mathrm{a}$ & $n / a$ & $\mathrm{n} / \mathrm{a}$ & 12.0 & $n / a$ & \\
\hline S13T001252 & & $7440-38-2$ & Arsenic & $\mathrm{ug} / \mathrm{mL}$ & 99.2 & $<5.00 \mathrm{E}-03$ & $<10.0$ & $n / a$ & $n / a$ & $n / a$ & $n / a$ & 10.0 & $n / a$ & $u$ \\
\hline S13T001252 & & $7440-39-3$ & Barium & $\mathrm{ug} / \mathrm{mL}$ & 101 & $<1.00 E-03$ & $<2.00$ & $n / a$ & $n / a$ & $n / a$ & $n / a$ & 2.00 & $n / a$ & u \\
\hline $\mathrm{S} 13 \mathrm{~T} 001252$ & & $7440-41-7$ & Beryllium & $\mathrm{ug} / \mathrm{mL}$ & 102 & $<1.00 \mathrm{E}-03$ & $<2.00$ & $n / a$ & $n / a$ & $n / a$ & $\mathrm{n} / \mathrm{a}$ & 2.00 & $n / a$ & $u$ \\
\hline S13T001252 & & $7440-70-2$ & Calcium & $u g / \mathrm{mL}$ & 95.5 & $<0.0800$ & $<160$ & $n / a$ & $\mathrm{n} / \mathrm{a}$ & $n / a$ & $n / a$ & 160 & $n / a$ & $u$ \\
\hline $\mathrm{S} 13 \mathrm{~T} 001252$ & & $7440-43-9$ & Cadmium & $\mathrm{ug} / \mathrm{mL}$ & 97.0 & $<1.00 \mathrm{E}-03$ & 3.33 & $\mathrm{n} / \mathrm{a}$ & $n / a$ & $n / a$ & $\mathrm{n} / \mathrm{a}$ & 2.00 & $n / a$ & $J$ \\
\hline $\mathrm{S} 13 \mathrm{~T} 001252$ & & $7440-47-3$ & Chromium & $\mathrm{ug} / \mathrm{mL}$ & 101 & $<1.00 \mathrm{E}-03$ & 678 & $n / a$ & $n / a$ & $\mathrm{n} / \mathrm{a}$ & $\mathrm{n} / \mathrm{a}$ & 2.00 & $n / a$ & \\
\hline S13T001252 & & 7440-53-1 & Europium & $\mathrm{ug} / \mathrm{mL}$ & 100 & $<1.00 \mathrm{E}-03$ & $<2.00$ & $n / a$ & $\mathrm{n} / \mathrm{a}$ & $n / a$ & $\mathrm{n} / \mathrm{a}$ & 2.00 & $n / a$ & $u$ \\
\hline S13T001252 & & $7439-89-6$ & Iron & $\mathrm{ug} / \mathrm{mL}$ & 103 & $<0.0100$ & 59.8 & $n / a$ & $n / a$ & $n / a$ & $\mathrm{n} / \mathrm{a}$ & 20.0 & $n / a$ & $J$ \\
\hline S13T001252 & & $7440-09-7$ & Potassium & $\mathrm{ug} / \mathrm{mL}$ & 98.7 & $<0.0200$ & $5.89 \mathrm{E}+03$ & $n / a$ & $n / a$ & n/a & $n / a$ & 40.0 & $n / a$ & \\
\hline S13T001252 & & $7439-91-0$ & Lanthanum & $\mathrm{ug} / \mathrm{mL}$ & 104 & $<1.00 \mathrm{E}-03$ & $<2.00$ & $\mathrm{n} / \mathrm{a}$ & $n / a$ & $n / a$ & $n / a$ & 2.00 & $n / a$ & $u$ \\
\hline S13T001252 & & $7439-93-2$ & Lithium & $u g / m L$ & 105 & $<1.00 \mathrm{E}-03$ & $<2.00$ & $\mathrm{n} / \mathrm{a}$ & $\mathrm{n} / \mathrm{a}$ & $n / a$ & $\mathrm{n} / \mathrm{a}$ & 2.00 & $n / a$ & $u$ \\
\hline $\mathrm{S} 13 \mathrm{~T} 001252$ & & $7439-98-7$ & Molybdenum & $\mathrm{ug} / \mathrm{mL}$ & 96.0 & $<1.00 \mathrm{E}-03$ & 32.2 & $n / a$ & $\mathrm{n} / \mathrm{a}$ & n/a & $\mathrm{n} / \mathrm{a}$ & 2.00 & $n / a$ & \\
\hline S13T001252 & & $7440-23-5$ & Sodium & $\mathrm{ug} / \mathrm{mL}$ & 96.0 & $<0.0400$ & $1.66 \mathrm{E}+05$ & $\mathrm{n} / \mathrm{a}$ & $\mathrm{n} / \mathrm{a}$ & $n / a$ & $\mathrm{n} / \mathrm{a}$ & 80.0 & $n / a$ & \\
\hline S13T001252 & & $7440-02-0$ & Nickel & $\mathrm{ug} / \mathrm{mL}$ & 100 & $<1.00 \mathrm{E}-03$ & 27.5 & $n / a$ & $\mathrm{n} / \mathrm{a}$ & $n / a$ & $n / a$ & 2.00 & $n / a$ & \\
\hline S13T001252 & & $7723-14-0$ & Phosphorus & $\mathrm{ug} / \mathrm{mL}$ & 96.1 & $<3.00 \mathrm{E}-03$ & 372 & $n / a$ & $n / a$ & $n / a$ & $n / a$ & 6.00 & $n / a$ & \\
\hline S13T001252 & & $7439-92-1$ & Lead & $u g / m L$ & 104 & $<6.00 \mathrm{E}-03$ & $<12.0$ & $\mathrm{n} / \mathrm{a}$ & $\mathrm{n} / \mathrm{a}$ & $n / a$ & $\mathrm{n} / \mathrm{a}$ & 12.0 & $n / a$ & $u$ \\
\hline S13T001252 & & $7704-34-9$ & Sulfur & $\mathrm{ug} / \mathrm{mL}$ & 100 & $<5.00 \mathrm{E}-03$ & $1.95 \mathrm{E}+03$ & $n / a$ & $\mathrm{n} / \mathrm{a}$ & $n / a$ & $\mathrm{n} / \mathrm{a}$ & 10.0 & $n / a$ & \\
\hline S13T001252 & & $7782-49-2$ & Selenium & $\mathrm{ug} / \mathrm{mL}$ & 99.0 & $<6.00 \mathrm{E}-03$ & $<12.0$ & $n / a$ & $\mathrm{n} / \mathrm{a}$ & n/a & $n / a$ & 12.0 & $n / a$ & $u$ \\
\hline S13T001252 & & $7440-21-3$ & Silicon & $u g / m L$ & 103 & $<5.00 \mathrm{E}-03$ & 69.8 & $n / a$ & $\mathrm{n} / \mathrm{a}$ & $n / a$ & $\mathrm{n} / \mathrm{a}$ & 10.0 & $n / a$ & $J$ \\
\hline
\end{tabular}


Table D-1. Tank 241-AW-106 Boildown Chemical Analysis Results for all Submitted Liquid Samples (20 sheets)

AW106 BLDN 2013

Data Summary Report

Sample Group: 20130122

Customer Group or SDG Number:

Segment Portion: Tank Composite (Supernatant Liquid)

Parent Sample Number: S13T001248

\begin{tabular}{|c|c|c|c|c|c|c|c|c|c|c|c|c|c|c|}
\hline Sample\# & A\# & CAS\# & Analyte & Unit & STD \% & Blank & Result & Duplicate & Average & RPD \% & Spk Rec \% & Det Limit & Cnt Err \% & Qual Flags \\
\hline \multicolumn{15}{|c|}{ ICP-RCRA Metals } \\
\hline S13T00 1252 & & $7440-24-6$ & Strontium & $\mathrm{ug} / \mathrm{mL}$ & 100 & $<2.00 \mathrm{E}-03$ & $<4.00$ & $\mathrm{n} / \mathrm{a}$ & $n / a$ & $\mathrm{n} / \mathrm{a}$ & $n / a$ & 4.00 & & u \\
\hline S13T00 1252 & & $7440-32-6$ & Titanium & $\mathrm{ug} / \mathrm{mL}$ & 97.8 & $<1.00 \mathrm{E}-03$ & $<2.00$ & $\mathrm{n} / \mathrm{a}$ & $\mathrm{n} / \mathrm{a}$ & $\mathrm{n} / \mathrm{a}$ & $\mathrm{n} / \mathrm{a}$ & 2.00 & & $\mathrm{u}$ \\
\hline S13T00 1252 & & 7440-28-0 & Thallium & $\mathrm{ug} / \mathrm{mL}$ & 97.3 & $<6.00 \mathrm{E}-03$ & $<12.0$ & $\mathrm{n} / \mathrm{a}$ & $n / a$ & $\mathrm{n} / \mathrm{a}$ & $n / a$ & 12.0 & & u \\
\hline S13T00 1252 & & $7440-66-6$ & Zinc & $\mathrm{ug} / \mathrm{mL}$ & 100 & $<4.00 \mathrm{E}-03$ & $<8.00$ & $n / a$ & $\mathrm{n} / \mathrm{a}$ & $n / a$ & $n / a$ & 8.00 & & $u$ \\
\hline S13T00 1252 & & $7440-67-7$ & Zirconium & $\mathrm{ug} / \mathrm{mL}$ & 98.2 & $<1.00 \mathrm{E}-03$ & 2.10 & $\mathrm{n} / \mathrm{a}$ & $n / a$ & $\mathrm{n} / \mathrm{a}$ & $n / a$ & 2.00 & $n / a$ & $\mathrm{~J}$ \\
\hline \multicolumn{15}{|c|}{$\mathrm{OH}$ - by Pot. Titration } \\
\hline S13T001252 & & HYDROXIDE & Hydroxide & $\mathrm{ug} / \mathrm{mL}$ & 88.8 & $<9.22$ & $1.70 E+04$ & $\mathrm{n} / \mathrm{a}$ & $\mathrm{n} / \mathrm{a}$ & $\mathrm{n} / \mathrm{a}$ & $\mathrm{n} / \mathrm{a}$ & $1.11 \mathrm{E}+03$ & $n / a$ & \\
\hline \multicolumn{15}{|c|}{ TIC/TOC by Acid Persulfate } \\
\hline S13T00 1252 & & TIC & Total inorganic carbon & $u g / m L$ & 98.0 & $<7.00$ & $8.76 \mathrm{E}+03$ & $\mathrm{n} / \mathrm{a}$ & $n / a$ & $\mathrm{n} / \mathrm{a}$ & $n / a$ & 70.0 & $\mathrm{n} / \mathrm{a}$ & \\
\hline S13T00 1252 & & TOC & Total organic carbon & $\mathrm{ug} / \mathrm{mL}$ & 85.7 & $<20.0$ & $1.58 \mathrm{E}+03$ & $\mathrm{n} / \mathrm{a}$ & $\mathrm{n} / \mathrm{a}$ & $n / a$ & $\mathrm{n} / \mathrm{a}$ & 200 & $n / a$ & \\
\hline
\end{tabular}

Parent Sample Number: S13T001249

\begin{tabular}{|c|c|c|c|c|c|c|c|c|c|c|c|c|c|c|}
\hline \begin{tabular}{|ll} 
Sample\# & $\mathbf{R}$ \\
\end{tabular} & A:\# & CAS\# & Analyte & Unit & STD \% & Blank & Result & Duplicate & Average & RPD \% & Spk Rec \% & Det Limit & Cnt Err \% & Qual Flags \\
\hline \multicolumn{15}{|c|}{ Anions and Small Organic Acids } \\
\hline S13T00 1253 & & $16984-48-8$ & Fluoride & $\mathrm{ug} / \mathrm{mL}$ & 95.2 & $<1.61 \mathrm{E}-03$ & $1.61 \mathrm{E}+03$ & $n / a$ & $n / a$ & $\mathrm{n} / \mathrm{a}$ & $n / a$ & 24.2 & $\mathrm{n} / \mathrm{a}$ & \\
\hline S13T00 1253 & & $866-14-8$ & Glycolate & ug/mL & 94.8 & $<9.37 \mathrm{E}-03$ & $<141$ & $n / a$ & $n / a$ & $n / a$ & $n / a$ & 141 & $n / a$ & $u$ \\
\hline S13T001253 & & $71-50-1$ & Acetate & ug/mL & 92.6 & $<6.04 \mathrm{E}-03$ & 678 & $n / a$ & $n / a$ & $n / a$ & $\mathrm{n} / \mathrm{a}$ & 90.6 & $n / a$ & $\mathrm{~J}$ \\
\hline S13T00 1253 & & $12311-97-6$ & Formate & ug/mL & 96.8 & $<4.67 \mathrm{E}-03$ & $1.59 \mathrm{E}+03$ & $n / a$ & $n / a$ & $\mathrm{n} / \mathrm{a}$ & $n / a$ & 70.0 & $n / a$ & \\
\hline S13T00 1253 & & $16887-00-6$ & Chloride & $\mathrm{ug} / \mathrm{mL}$ & 95.1 & 0.0140 & $2.42 \mathrm{E}+03$ & $n / a$ & $n / a$ & $n / a$ & $n / a$ & 150 & $\mathrm{n} / \mathrm{a}$ & \\
\hline S13T00 1253 & & $14797-65-0$ & Nitrite & ug $/ \mathrm{mL}$ & 101 & $<0.0192$ & $5.01 E+04$ & $n / a$ & $n / a$ & $n / a$ & $n / a$ & 288 & $\mathrm{n} / \mathrm{a}$ & \\
\hline S13T00 1253 & & $14808-79-8$ & Sulfate & $\mathrm{ug} / \mathrm{mL}$ & 95.3 & $<0.0187$ & $7.13 E+03$ & $n / a$ & $n / a$ & $n / a$ & $\mathrm{n} / \mathrm{a}$ & 280 & $n / a$ & \\
\hline S13TO0 1253 & & $338-70-5$ & Oxalate & $\mathrm{ug} / \mathrm{mL}$ & 96.6 & $<0.0231$ & $<346$ & $n / a$ & $\mathrm{n} / \mathrm{a}$ & $n / a$ & $\mathrm{n} / \mathrm{a}$ & 346 & $n / a$ & u \\
\hline S13T00 1253 & & $24959-67-9$ & Bromide & ug $/ \mathrm{mL}$ & 96.0 & $<0.0580$ & $<870$ & $n / a$ & $n / a$ & $\mathrm{n} / \mathrm{a}$ & $n / a$ & 870 & $n / a$ & u \\
\hline S13T00 1253 & & $14797-55-8$ & Nitrate & ug $/ \mathrm{mL}$ & 94.4 & $<0.0208$ & $1.78 \mathrm{E}+05$ & $n / a$ & $n / a$ & $n / a$ & $\mathrm{n} / \mathrm{a}$ & 312 & $n / a$ & \\
\hline S13T00 1253 & & $14265-44-2$ & Phosphate & ug $/ \mathrm{mL}$ & 95.5 & $<0.0167$ & $1.74 E+03$ & $n / a$ & $n / a$ & $n / a$ & $n / a$ & 250 & $n / a$ & $\mathrm{~J}$ \\
\hline \multicolumn{15}{|l|}{ DENSITY } \\
\hline S13T00 1253 & & Density & Density & $g / m L$ & 99.42 & $\mathrm{n} / \mathrm{a}$ & 1.368 & $n / a$ & $n / a$ & $n / a$ & $n / a$ & $1.000 \mathrm{E}-03$ & $\mathrm{n} / \mathrm{a}$ & \\
\hline \multicolumn{15}{|c|}{ ICP-RCRA M } \\
\hline
\end{tabular}


Table D-1. Tank 241-AW-106 Boildown Chemical Analysis Results for all Submitted Liquid Samples (20 sheets)

AW106 BLDN 2013

Data Summary Report

Sample Group: 20130122

Customer Group or SDG Number:

Segment Portion: Tank Composite (Supernatant Liquid)

Parent Sample Number: S13T001249

\begin{tabular}{|c|c|c|c|c|c|c|c|c|c|c|c|c|c|c|}
\hline $\begin{array}{|ll|}\text { Sample\# } & \text { R } \\
\end{array}$ & A.\# & CAS\# & Analyte & Unit & STD \% & Blank & Result & Duplicate & Average & RPD \% & Spk Rec \% & Det Limit & Cnt Err \% & Qual Flags \\
\hline \multicolumn{15}{|c|}{ ICP-RCRA Metals } \\
\hline S13T00 1253 & & $7429-90-5$ & Aluminum & $\mathrm{ug} / \mathrm{mL}$ & 95.5 & $<6.00 \mathrm{E}-03$ & $6.89 \mathrm{E}+03$ & $\mathrm{n} / \mathrm{a}$ & $n / a$ & $\mathrm{n} / \mathrm{a}$ & $n / a$ & 12.0 & $n / a$ & \\
\hline S13T00 1253 & & $7440-38-2$ & Arsenic & $\mathrm{ug} / \mathrm{mL}$ & 99.2 & $<5.00 \mathrm{E}-03$ & $<10.0$ & $\mathrm{n} / \mathrm{a}$ & $n / a$ & $\mathrm{n} / \mathrm{a}$ & $n / a$ & 10.0 & $n / a$ & $u$ \\
\hline S13T00 1253 & & $7440-39-3$ & Barium & $\mathrm{ug} / \mathrm{mL}$ & 101 & $<1.00 \mathrm{E}-03$ & $<2.00$ & $\mathrm{n} / \mathrm{a}$ & $\mathrm{n} / \mathrm{a}$ & $\mathrm{n} / \mathrm{a}$ & $\mathrm{n} / \mathrm{a}$ & 2.00 & $n / a$ & $u$ \\
\hline S13T001253 & & $7440-41-7$ & Beryllium & $\mathrm{ug} / \mathrm{mL}$ & 102 & $<1.00 \mathrm{E}-03$ & $<2.00$ & $\mathrm{n} / \mathrm{a}$ & n/a & $\mathrm{n} / \mathrm{a}$ & $\mathrm{n} / \mathrm{a}$ & 2.00 & $n / a$ & $u$ \\
\hline S13T00 1253 & & $7440-70-2$ & Calcium & $u g / m L$ & 95.5 & $<0.0800$ & $<160$ & $\mathrm{n} / \mathrm{a}$ & $\mathrm{n} / \mathrm{a}$ & $\mathrm{n} / \mathrm{a}$ & $n / a$ & 160 & $n / a$ & $\mathrm{u}$ \\
\hline S13T00 1253 & & $7440-43-8$ & Cadmium & $\mathrm{ug} / \mathrm{mL}$ & 97.0 & $<1.00 \mathrm{E}-03$ & 3.11 & $\mathrm{n} / \mathrm{a}$ & $n / a$ & $\mathrm{n} / \mathrm{a}$ & $n / a$ & 2.00 & $n / a$. & $\mathrm{J}$ \\
\hline S13T001253 & & $7440-47-3$ & Chromium & $u g / \mathrm{mL}$ & 101 & $<1.00 \mathrm{E}-03$ & 581 & $\mathrm{n} / \mathrm{a}$ & $\mathrm{n} / \mathrm{a}$ & $\mathrm{n} / \mathrm{a}$ & $\mathrm{n} / \mathrm{a}$ & 2.00 & $n / a$ & \\
\hline S13T001253 & & $7440-53-1$ & Europium & $u g / \mathrm{mL}$ & 100 & $<1.00 \mathrm{E}-03$ & $<2.00$ & $\mathrm{n} / \mathrm{a}$ & $\mathrm{n} / \mathrm{a}$ & $\mathrm{n} / \mathrm{a}$ & $\mathrm{n} / \mathrm{a}$ & 2.00 & $n / a$ & $u$ \\
\hline S13T00 1253 & & $7439-89-6$ & Iron & $u g / m L$ & 103 & $<0.0100$ & 53.3 & $\mathrm{n} / \mathrm{a}$ & $n / a$ & $\mathrm{n} / \mathrm{a}$ & $\mathrm{n} / \mathrm{a}$ & 20.0 & $n / a$. & $\mathrm{J}$ \\
\hline S13T00 1253 & & $7440-09-7$ & Potassium & $\mathrm{ug} / \mathrm{mL}$ & 98.7 & $<0.0200$ & $5.07 \mathrm{E}+03$ & $\mathrm{n} / \mathrm{a}$ & $\mathrm{n} / \mathrm{a}$ & $\mathrm{n} / \mathrm{a}$ & $\mathrm{n} / \mathrm{a}$ & 40.0 & $n / a$ & \\
\hline S13T00 1253 & & $7439-91-0$ & Lanthanum & $\mathrm{ug} / \mathrm{mL}$ & 104 & $<1.00 \mathrm{E}-03$ & $<2.00$ & $\mathrm{n} / \mathrm{a}$ & $\mathrm{n} / \mathrm{a}$ & $\mathrm{n} / \mathrm{a}$ & $\mathrm{n} / \mathrm{a}$ & 2.00 & $\mathrm{n} / \mathrm{a}$ & $u$ \\
\hline S13T001253 & & $7439-93-2$ & Lithium & ug $/ \mathrm{mL}$ & 105 & $<1.00 \mathrm{E}-03$ & $<2.00$ & $\mathrm{n} / \mathrm{a}$ & $n / a$ & $n / a$ & $n / a$ & 2.00 & $n / a$ & u \\
\hline S13T001253 & & $7439-98-7$ & Molybdenum & $u g / \mathrm{mL}$ & 96.0 & $<1.00 \mathrm{E}-03$ & 27.3 & $n / a$ & $n / a$ & $n / a$ & $n / a$ & 2.00 & $n / a$ & \\
\hline S13T00 1253 & & $7440-23-5$ & Sodium & $u g / m L$ & 96.0 & $<0.0400$ & $1.45 \mathrm{E}+05$ & $n / a$ & $n / a$ & $\mathrm{n} / \mathrm{a}$ & $n / a$ & 80.0 & $n / a$ & \\
\hline S13T00 1253 & & $7440-02-0$ & Nickel & $\mathrm{ug} / \mathrm{mL}$ & 100 & $<1.00 \mathrm{E}-03$ & 23.7 & $n / a$ & $n / a$ & $\mathrm{n} / \mathrm{a}$ & $n / a$ & 2.00 & $n / a$ & \\
\hline S13T00 1253 & & $7723-14-0$ & Phosphorus & ug $/ \mathrm{mL}$ & 96.1 & $<3.00 \mathrm{E}-03$ & 461 & $\mathrm{n} / \mathrm{a}$ & $n / a$ & $n / a$ & $n / a$ & 6.00 & $n / a$ & \\
\hline S13T001253 & & $7439-92-1$ & Lead & $u g / \mathrm{mL}$ & 104 & $<6.00 \mathrm{E}-03$ & $<12.0$ & $\mathrm{n} / \mathrm{a}$ & $n / a$ & $\mathrm{n} / \mathrm{a}$ & $\mathrm{n} / \mathrm{a}$ & 12.0 & $n / a$ & u \\
\hline S13T00 1253 & & $7704-34-9$ & Sulfur & $u g / \mathrm{mL}$ & 100 & $<5.00 \mathrm{E}-03$ & $2.52 \mathrm{E}+03$ & $n / a$ & $\mathrm{n} / \mathrm{a}$ & $\mathrm{n} / \mathrm{a}$ & $n / a$ & 10.0 & $n / a$ & \\
\hline S13T00 1253 & & $7782-49-2$ & Selenium & $u g / m L$ & 99.0 & $<6.00 \mathrm{E}-03$ & $<12.0$ & $\mathrm{n} / \mathrm{a}$ & $\mathrm{n} / \mathrm{a}$ & $\mathrm{n} / \mathrm{a}$ & $\mathrm{n} / \mathrm{a}$ & 12.0 & $n / a$ & $u$ \\
\hline S13T00 1253 & & $7440-21-3$ & Silicon & $\mathrm{ug} / \mathrm{mL}$ & 103 & $<5.00 \mathrm{E}-03$ & 60.7 & $\mathrm{n} / \mathrm{a}$ & $\mathrm{n} / \mathrm{a}$ & $n / a$ & $n / a$ & 10.0 & $n / a$. & $\mathrm{J}$ \\
\hline S13T001253 & & $7440-24-6$ & Strontium & $\mathrm{ug} / \mathrm{mL}$ & 100 & $<2.00 \mathrm{E}-03$ & $<4.00$ & $\mathrm{n} / \mathrm{a}$ & $\mathrm{n} / \mathrm{a}$ & $\mathrm{n} / \mathrm{a}$ & $\mathrm{n} / \mathrm{a}$ & 4.00 & $n / a$ & u \\
\hline S13T001253 & & $7440-32-6$ & Titanium & $\mathrm{ug} / \mathrm{mL}$ & 97.8 & $<1.00 \mathrm{E}-03$ & $<2.00$ & $\mathrm{n} / \mathrm{a}$ & $\mathrm{n} / \mathrm{a}$ & $\mathrm{n} / \mathrm{a}$ & $n / a$ & 2.00 & $n / a$ & u \\
\hline S13T001253 & & $7440-28-0$ & Thallium & ug $/ \mathrm{mL}$ & 97.3 & $<6.00 \mathrm{E}-03$ & $<12.0$ & $\mathrm{n} / \mathrm{a}$ & $n / a$ & $n / a$ & $n / a$ & 12.0 & $n / a$ & u \\
\hline S13T00 1253 & & $7440-66-6$ & Zinc & $u g / m L$ & 100 & $<4.00 \mathrm{E}-03$ & $<8.00$ & $n / a$ & $\mathrm{n} / \mathrm{a}$ & $\mathrm{n} / \mathrm{a}$ & $\mathrm{n} / \mathrm{a}$ & 8.00 & $n / a$ & $\mathrm{u}$ \\
\hline S13T00 1253 & & $7440-67-7$ & Zirconium & $\mathrm{ug} / \mathrm{mL}$ & 98.2 & $<1.00 \mathrm{E}-03$ & 2.64 & $n / a$ & $n / a$ & $\mathrm{n} / \mathrm{a}$ & $n / a$ & 2.00 & $n / a$ & $\mathrm{~J}$ \\
\hline \multicolumn{15}{|c|}{$\mathrm{OH}$ - by Pot. Titration } \\
\hline S13T00 1253 & & HYDROXIDE & Hydroxide & $u g / \mathrm{mL}$ & 88.8 & $<9.22$ & $1.52 E+04$ & $\mathrm{n} / \mathrm{a}$ & $\mathrm{n} / \mathrm{a}$ & $\mathrm{n} / \mathrm{a}$ & $n / a$ & $1.11 \mathrm{E}+03$ & $n / a$ / & \\
\hline
\end{tabular}


Table D-1. Tank 241-AW-106 Boildown Chemical Analysis Results for all Submitted Liquid Samples (20 sheets)

AW106 BLDN 2013

Data Summary Report

Sample Group: 20130122

Customer Group or SDG Number:

Segment Portion: Tank Composite (Supernatant Liquid)

Parent Sample Number: S13T001249

\begin{tabular}{|c|c|c|c|c|c|c|c|c|c|c|c|c|c|c|}
\hline Sample\# & A\# & CAS\# & Analyte & Unit & STD \% & Blank & Result & Duplicate & Average & RPD \% & Spk Rec \% & Det Limit & Cnt Err \% & Qual Flags \\
\hline S13TO0 1253 & & TIC & Total inorganic carbon & $\mathrm{ug} / \mathrm{mL}$ & 98.0 & $<7.00$ & $7.33 E+03$ & $\mathrm{n} / \mathrm{a}$ & $n / a$ & $n / a$ & $n / a$ & 70.0 & $n / a$ & \\
\hline S13T001253 & & TOC & Total organic carbon & ug $/ \mathrm{mL}$ & 85.7 & $<20.0$ & $1.44 E+03$ & $\mathrm{n} / \mathrm{a}$ & $\mathrm{n} / \mathrm{a}$ & $n / a$ | & $n / a$ & 200 & $\mathrm{n} / \mathrm{a}$ & \\
\hline \multicolumn{15}{|c|}{ Total Carbon by Furnace } \\
\hline S13T00 1253 & & TC & Total carbon & ug $/ \mathrm{mL}$ & 100 & 10.5 & $8.91 \mathrm{E}+03$ & $\mathrm{n} / \mathrm{a}$ & $n / a$ & $\mathrm{n} / \mathrm{a}$ & $n / a$ & 405 & $\mathrm{n} / \mathrm{a}$ & \\
\hline
\end{tabular}


LAB-RPT-13-00003 R0

ATTACHMENT E

SOLID PHASE CHARACTERIZATION OF BOILDOWN SOLIDS 
LAB-RPT-13-00003 R0

Attachment E

\section{Solid Phase Characterization Results for the Tank 241-AW-106 Boildown Samples}

Four samples were received on 3/11/2013 for solid phase characterization (SPC) from the tank 241-AW-106 boildown experiment performed at the 222-S Laboratory. The 4 samples were labeled with the following OmniLIMS numbers with the corresponding concentration or dilution step in parentheses, S13T001244 (Con-5), S13T001245 (Con-6), S13T001246 (Con-7), and S13T001254 (Dil-3). All samples were in the form of wet, fine-grained, white solids contained in 25-mL glass vials with a residual supernatant liquid (clear, yellow) on top of the solids.

The samples were prepared for scanning electron microscopy (SEM) analysis using the residual supernatant liquid to help disperse the particulate. This was accomplished by placing a 37-mm diameter cellulose backing pad and a 0.45 -micron pore size, Nucleopore polycarbonate filter on the fritted glass base of a filtration flask connected to a trap and house vacuum. A filtration funnel was then placed on the filter stack and clamped into place. For each sample, a pipette was inserted in the sample vial and used to stir the slurry of particulate and supernatant liquid. A small portion of the solids was then transferred, via pipette, to the filtration stand and was streaked onto the filter surface. The vacuum apparatus was then quickly and gently shaken to help disperse the solids across the filter surface, and the vacuum was immediately turned on. When the fluid had drained from the filter surface, the clamp and funnel were removed, and the filter was allowed to completely dry. A section of the filter was cut out and, using carbon paint, affixed to an aluminum SEM stub containing a carbon planchet. The resulting SEM specimens were then coated with a conductive coating of carbon by evaporative deposition.

SEM analysis was conducted using an Aspex $\AA^{5}$ Personal Scanning Electron Microscope (PSEM), Model II, with a Noran light element energy dispersive spectrometer (EDS) for chemical analysis using procedure ATS-LT-161-100, 222-S Laboratory Sample Preparation and Operating Procedure for Scanning Electron Microscopes, and recorded in the controlled laboratory notebook, HNF-N-832-1, "PSEM Instrument Notebook," page 182. The instrument was operated at an accelerating voltage of 20 $\mathrm{kV}$, and the samples were mounted at a working distance of $20 \mathrm{~mm}$. All images were acquired in secondary electron image (SEI) mode. EDS spectra were acquired for 30 seconds live time (unless noted) on relatively smooth surfaces (either flat or sloping toward the detector) near the center of the image.

For polarized light microscopy (PLM) analysis, all four samples had sufficient liquid to be mounted in the original liquor. For a full description of the individual images, see the controlled laboratory notebook HNF-N-395-1, "Polarized Light Microscopy Sample Log,” pages 116-117.

The samples were prepared for X-ray diffraction (XRD) analysis by placing a fraction on a filter paper to remove interstitial liquid, which was transferred to the well of a quartz zero-background slide, compressed with the plane of a glass slide, fixed with collodion binder, and allowed to dry. XRD analysis was performed on March 11-13, 2012 in accordance with ATS-LT-507-103, Revision B-0, "222-S Laboratory X-Ray Diffractometry (XRD) Using the Rigaku MiniFlex II." Refer to laboratory notebook HNF-N-710-1, "Rigaku ${ }^{\circledR}{ }^{6}$ MiniFlex II X-Ray Diffractometer (XRD) Maintenance and Operations," page 22 , for test information and specifics. The sample compositions reported below are relative amounts based upon all the crystalline species present in each individual sample. Nitratine and sodium nitrite are speculated to have crystallized from the interstitial liquid when the samples were dried during sample preparation.

\footnotetext{
${ }^{5}$ Aspex ${ }^{\circledR}$ is a registered trademark of Aspex Corporation, Delmont, Pennsylvania.

${ }^{6}$ Rigaku ${ }^{\circ}$ is a registered trademark of Rigaku/USA, Inc., Danvers, Massachusetts.
} 


\section{S13T001244}

Analysis by PLM detected three main phases: natrophosphate (bipyramidal isotropic phase), kogarkoite (flat, hexagonal or shards thereof, anisotropic), and sodium carbonate (mostly needle form with some small laths). The image on the left in Figure E-1 is an overview, while the image on the right focuses on the cluster of needles. In both cases, the crossed polarizers $(\mathrm{crP}+)$ were in place.

\section{Figure E-1. Polarized Light Microscopy Analysis of Sample S13T001244.}
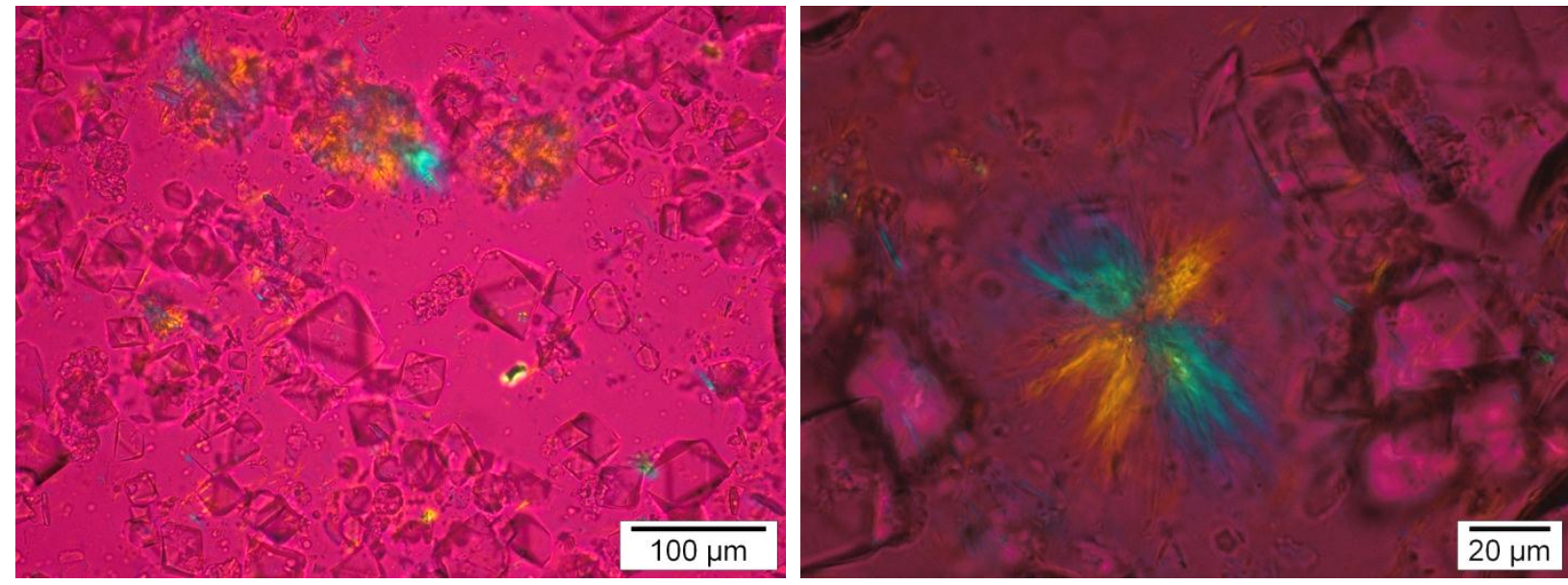

(S13T001244, 20x, crP+, Red I compensator)

(S13T001244, 60x, crP+, Red I compensator)

Analysis by XRD observed the sample to consist of a minimal amount of homogeneous yellowish-white fine solids in a light yellowish liquid, and once dried appeared to be homogeneous light yellowish-white fine solids. Five different phases in the sample were identified; these are listed in Table E-1 and identified on the spectrum in Figure E-2.

Table E-1. Phases and Relative Amounts Identified in Sample S13T001244.

\begin{tabular}{|l|l|l|l|}
\hline \multicolumn{1}{|c|}{ Chemical Name } & \multicolumn{1}{|c|}{ Mineral Name } & \multicolumn{1}{c|}{ Formula } & $\sim$ Rel. Amount \\
\hline Sodium Fluoride Sulfate & Kogarkoite & $\mathrm{Na}_{3} \mathrm{SO}_{4} \mathrm{~F}$ & Minor \\
\hline Sodium Fluoride Phosphate Hydrate & Natrophosphate & $\mathrm{Na}_{7} \mathrm{~F}_{(}\left(\mathrm{PO}_{4}\right)_{2} \cdot 19 \mathrm{H}_{2} \mathrm{O}$ & Major \\
\hline Sodium Nitrate & Nitratine & $\mathrm{NaNO}_{3}$ & Major \\
\hline Sodium Nitrite & -- & $\mathrm{NaNO}_{2}$ & Minor \\
\hline Sodium Carbonate Monohydrate & Thermonatrite & $\mathrm{Na}_{2} \mathrm{CO}_{3} \cdot \mathrm{H}_{2} \mathrm{O}$ & Major \\
\hline
\end{tabular}


LAB-RPT-13-00003 R0

Attachment E

Figure E-2. X-Ray Diffraction Spectrum from Sample S13T001244.

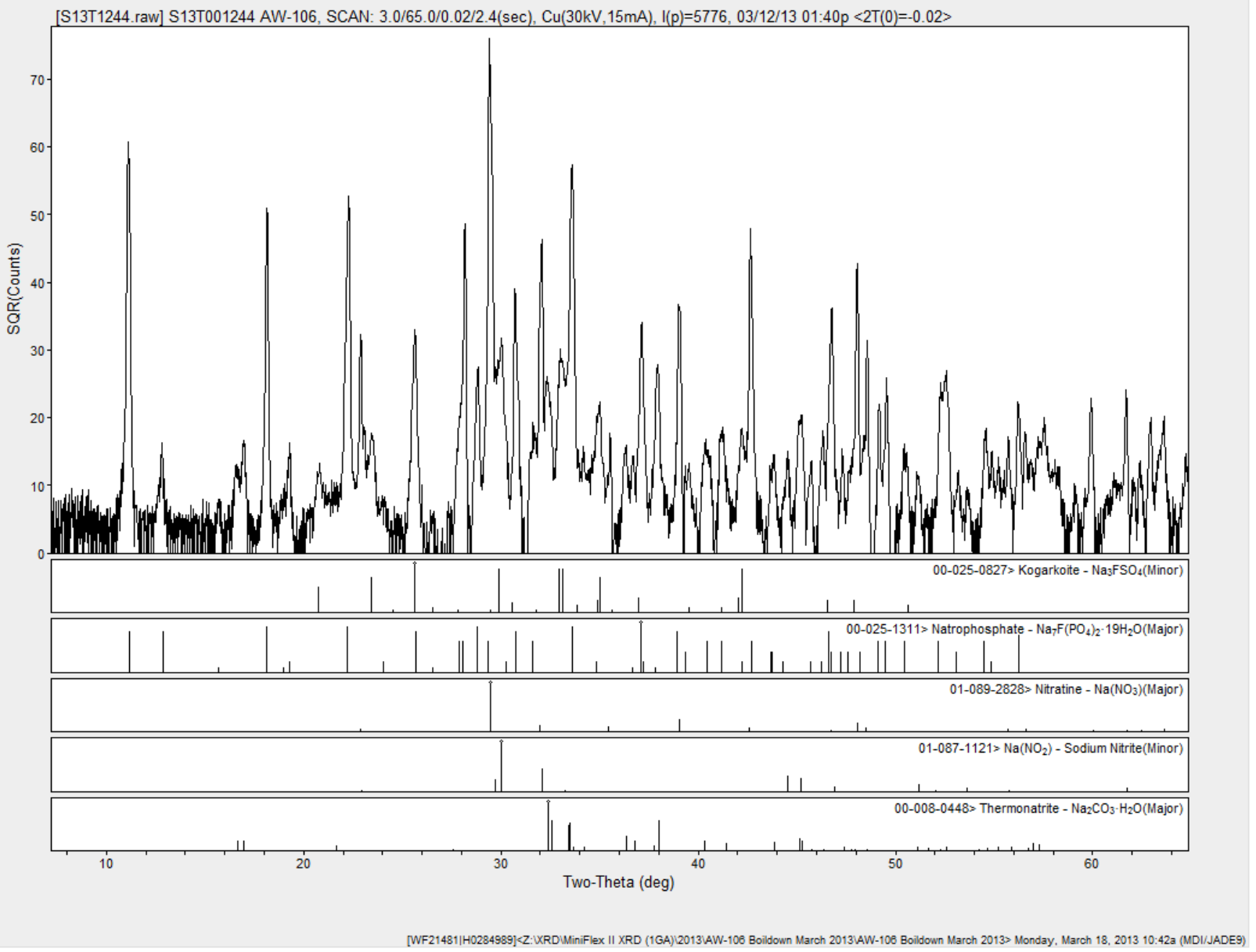

The SEM analysis identified three main phases present in the sample. They consisted of larger, octahedral crystals of sodium fluoride phosphate identified as natrophosphate, Figure E-3b; aggregates and smaller crystals of sodium fluoride sulfate, Figure E-3c; and small, acicular crystals rich in sodium, carbon, and oxygen, Figure E-4. 
LAB-RPT-13-00003 R0

Attachment $\mathrm{E}$

Figure E-3. Scanning Electron Microscopy Images and Energy Dispersive Spectrometry Spectra of Two Phases in Sample S13T001244.
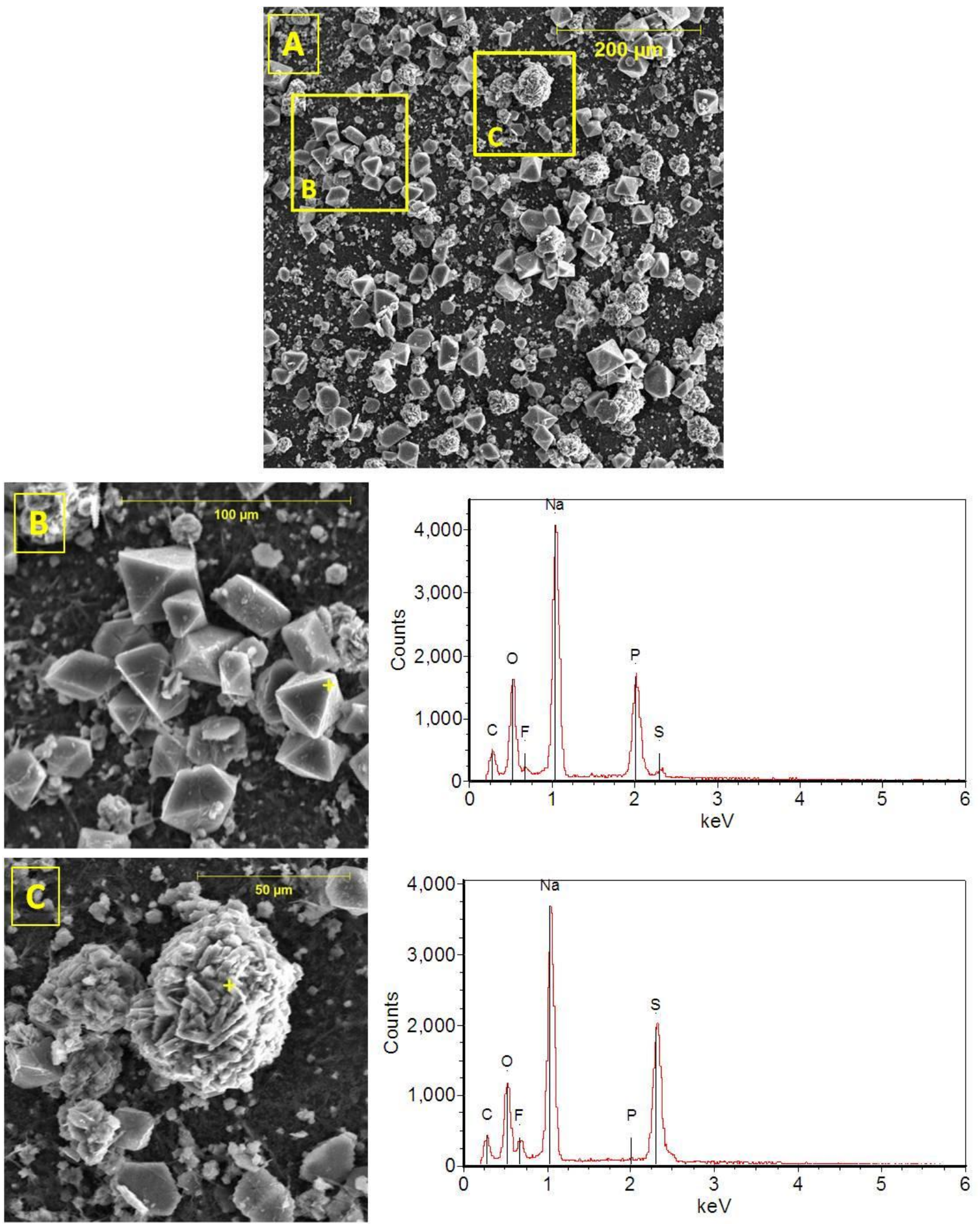
LAB-RPT-13-00003 R0

Attachment E

Figure E-4. Scanning Electron Microscopy Image and Energy Dispersive Spectrometry Spectrum of Acicular Particles in Sample S13T001244.
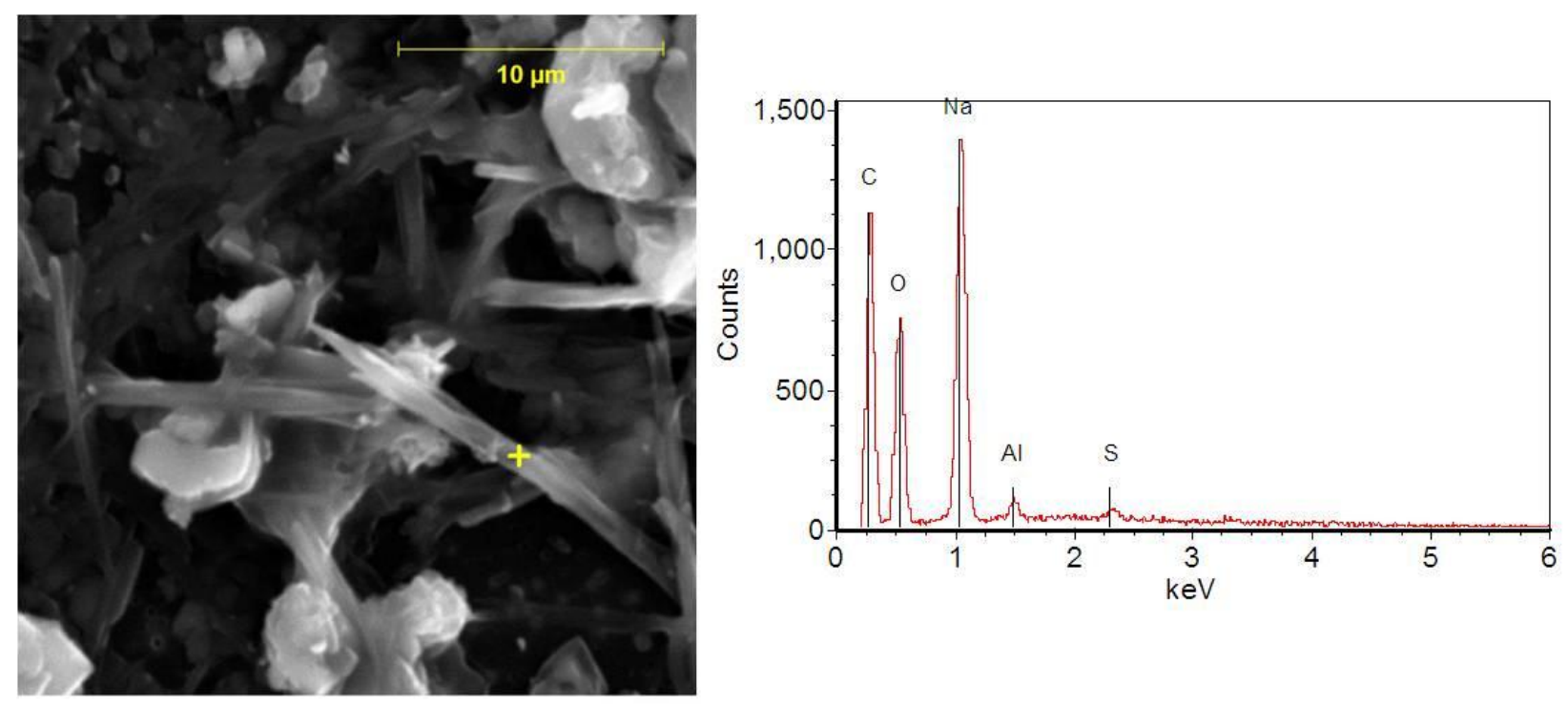


\section{LAB-RPT-13-00003 R0 \\ Attachment E}

\section{S13T001245}

Analysis by PLM showed that sodium carbonate was the dominant phase, followed by clusters of kogarkoite (greenish color, confirmed with SEM images), sodium oxalate needles, and natrophosphate crystals, Figure E-5. One crystal of sodium nitrate was found.

Figure E-5. Polarized Light Microscopy Analysis of Sample S13T001245.
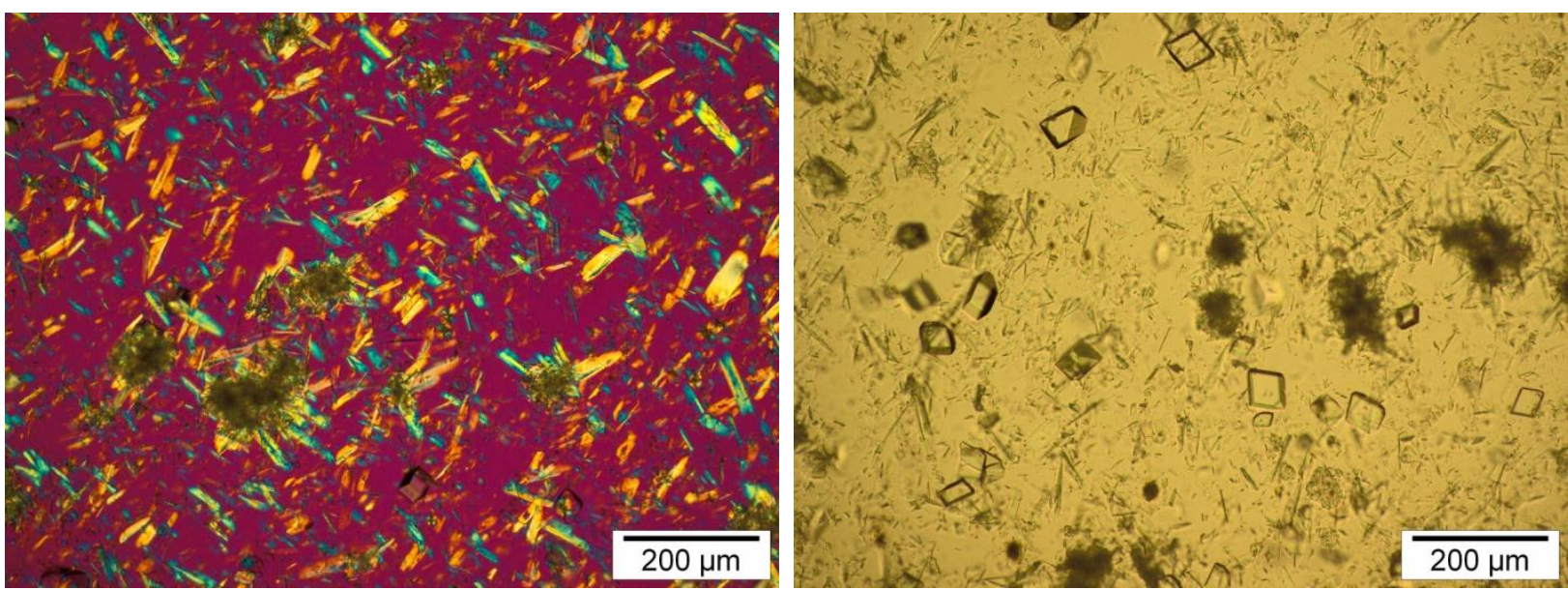

(S13T001245, 10x, crP+, Red I compensator)

(S13T001245, 10x, uncrP)

Analysis by XRD identified the major phase as nitratine $\left[\mathrm{NaNO}_{3}\right]$. Kogarkoite $\left[\mathrm{Na}_{3} \mathrm{SO}_{4} \mathrm{~F}\right]$, natrophosphate $\left[\mathrm{Na}_{7} \mathrm{~F}\left(\mathrm{PO}_{4}\right)^{2} \bullet 19 \mathrm{H}_{2} \mathrm{O}\right]$, sodium nitrite $\left[\mathrm{NaNO}_{2}\right]$, and thermonatrite $\left[\mathrm{Na}_{2} \mathrm{CO}_{3} \cdot \mathrm{H}_{2} \mathrm{O}\right]$ were identified as minor phases. The results are tabulated in Table E-2, and the XRD spectrum is shown in Figure E-6.

Table E-2. Phases and Relative Amounts Identified in Sample S13T001245.

\begin{tabular}{|l|l|l|l|}
\hline \multicolumn{1}{|c|}{ Chemical Name } & \multicolumn{1}{|c|}{ Mineral Name } & \multicolumn{1}{c|}{ Formula } & \multicolumn{1}{|c|}{ Rel. Amount } \\
\hline Sodium Fluoride Sulfate & Kogarkoite & $\mathrm{Na}_{3} \mathrm{SO}_{4} \mathrm{~F}$ & Minor \\
\hline Sodium Fluoride Phosphate Hydrate & Natrophosphate & $\mathrm{Na}_{7} \mathrm{~F}\left(\mathrm{PO}_{4}\right)_{2} \cdot 19 \mathrm{H}_{2} \mathrm{O}$ & Minor \\
\hline Sodium Nitrate & Nitratine & $\mathrm{NaNO}_{3}$ & Major \\
\hline Sodium Nitrite & -- & $\mathrm{NaNO}_{2}$ & Minor \\
\hline Sodium Carbonate Monohydrate & Thermonatrite & $\mathrm{Na}_{2} \mathrm{CO}_{3} \cdot \mathrm{H}_{2} \mathrm{O}$ & Minor \\
\hline
\end{tabular}


LAB-RPT-13-00003 R0

Attachment E

Figure E-6. X-Ray Diffraction Spectrum from Sample S13T001245.

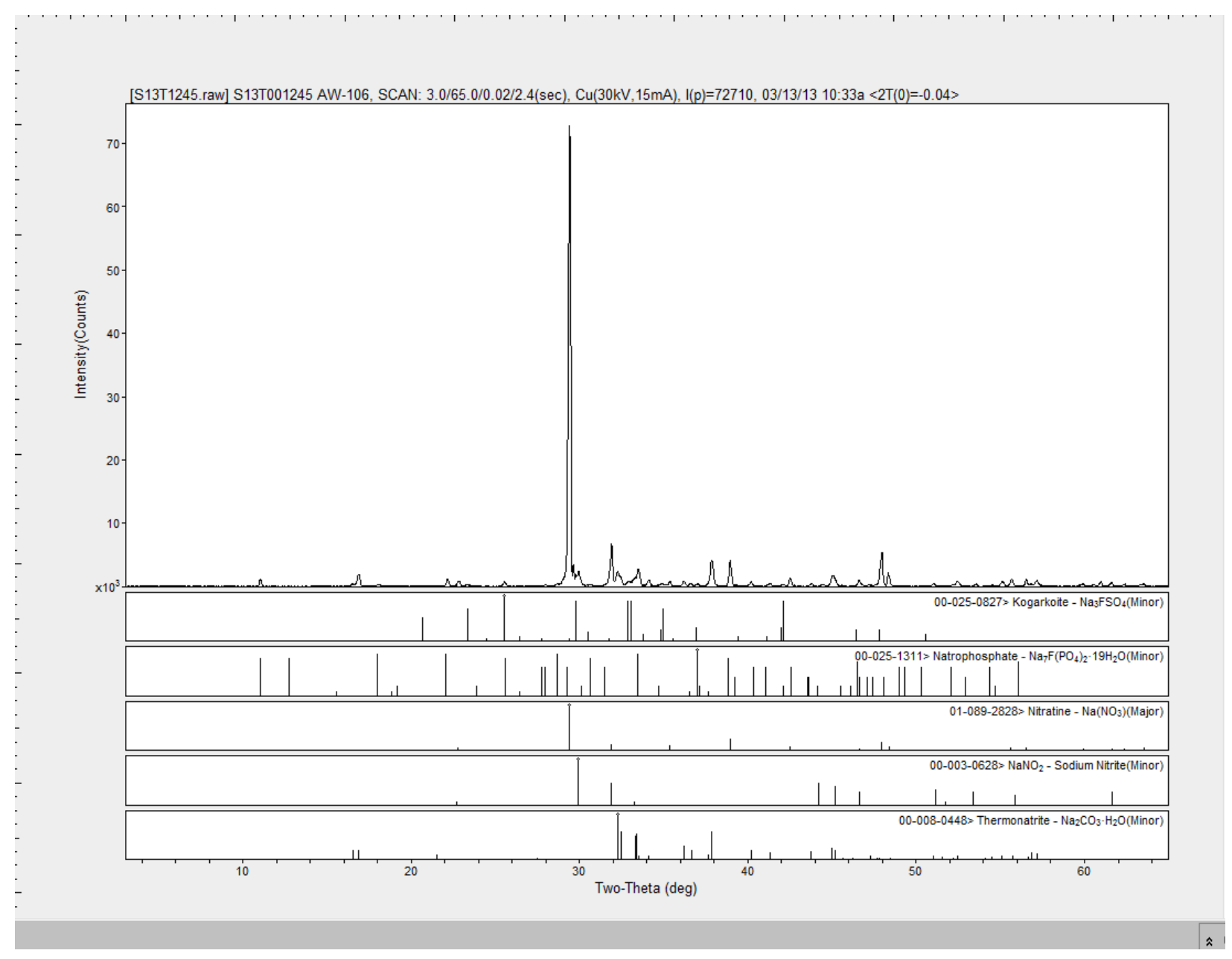

Analysis of the sample by SEM showed three major phases. The zoomed-in image on the right in Figure E-7 shows all three phases; Spot 1 is a sodium fluoride phosphate (natrophosphate), Spot 2 is a sodium fluoride sulfate, and Spot 3 is a sodium and carbon-rich phase which is possibly sodium carbonate.

Another sodium- and carbon-rich phase is shown in Figure E-8 which also has trace aluminum, sulfur, and potassium. In addition, a trace amount of sodium nitrate was observed as evidenced in Figure E-9. 
LAB-RPT-13-00003 R0

Attachment E

Figure E-7. Scanning Electron Microscopy Images and Energy Dispersive Spectroscopy Spectra of Three Phases in Sample S13T001245.
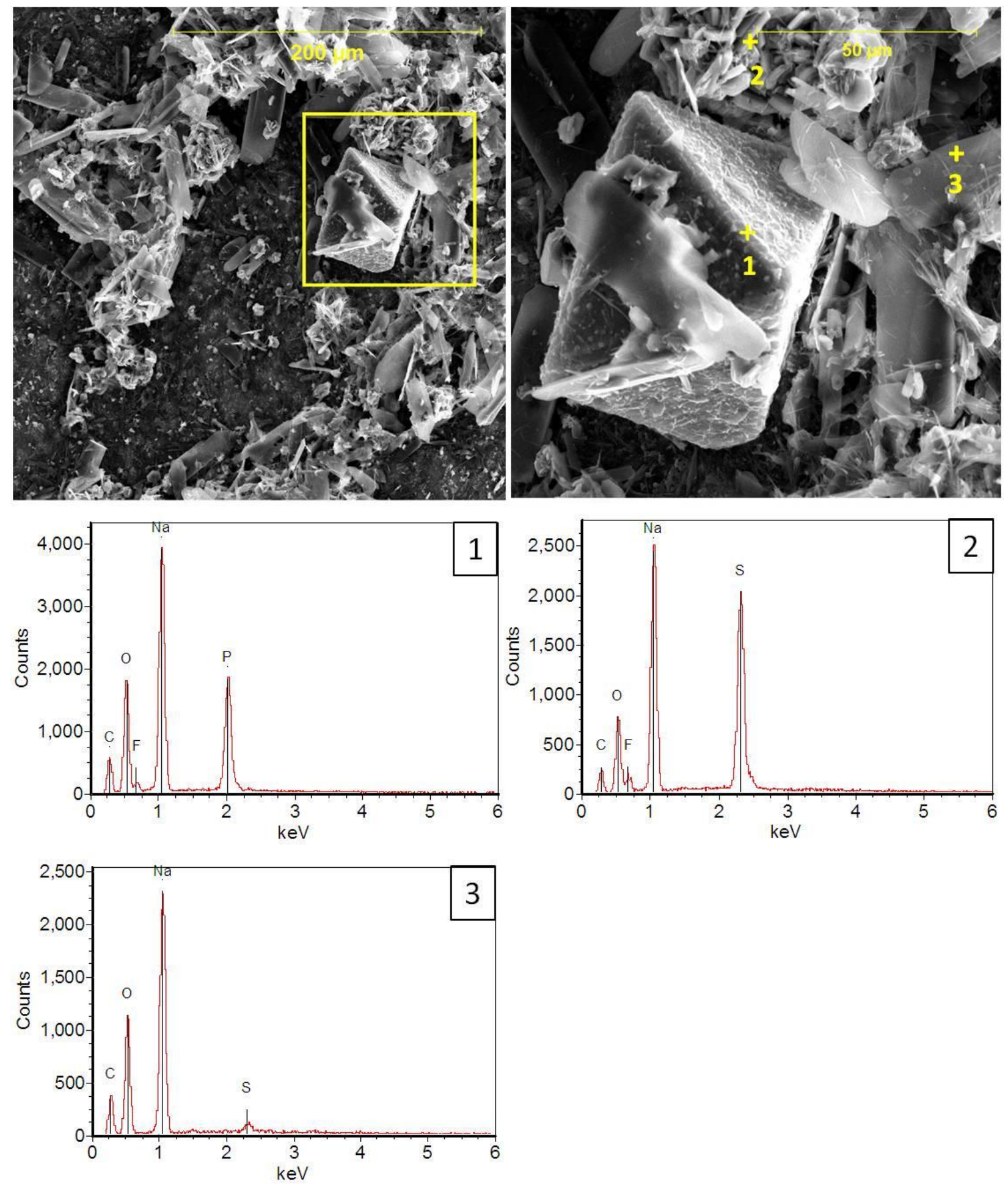


\section{LAB-RPT-13-00003 R0 \\ Attachment E}

Figure E-8. Scanning Electron Microscopy Image and Energy Dispersive Spectroscopy Spectrum of Thread-Like Particles in Sample S13T001245.
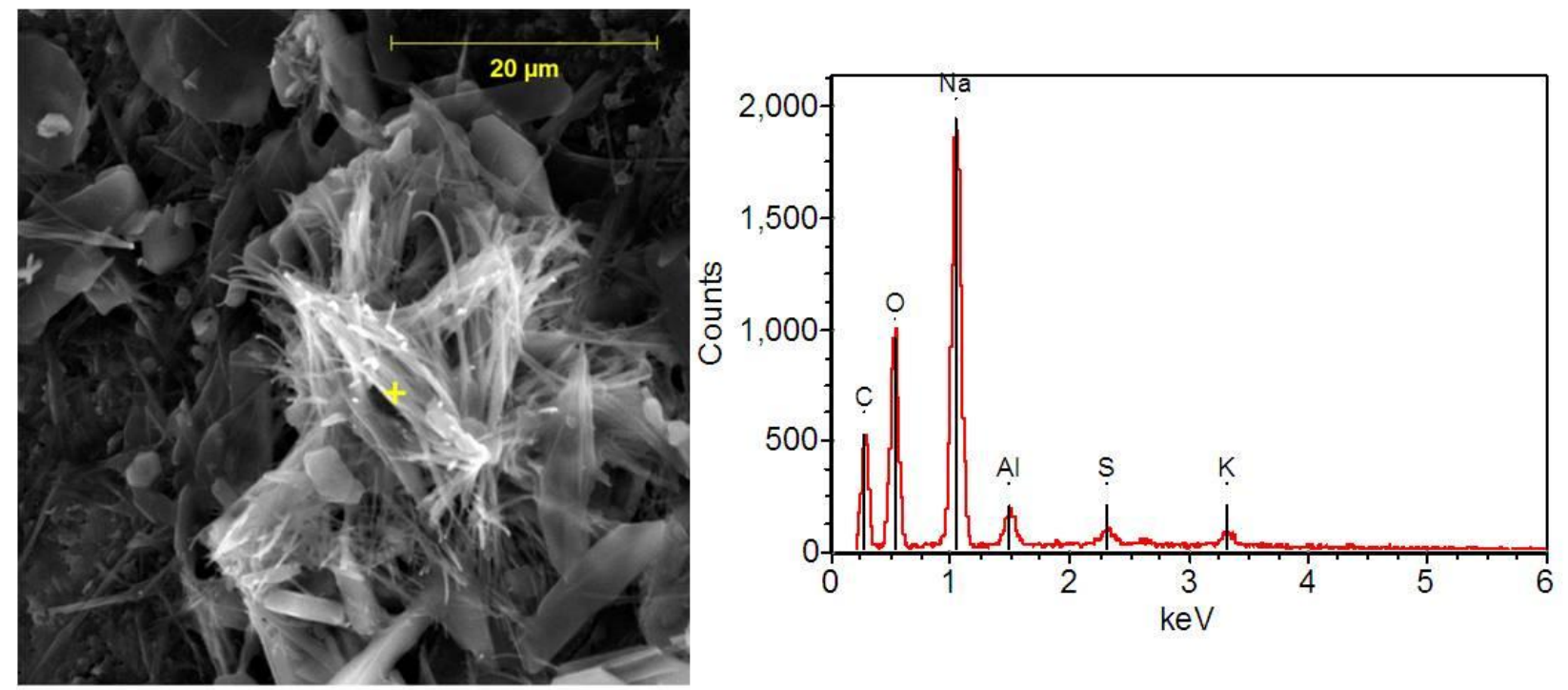

Figure E-9. Scanning Electron Microscopy Image and Energy Dispersive Spectroscopy Spectrum of a Sodium Nitrate Particle in Sample S13T001245.
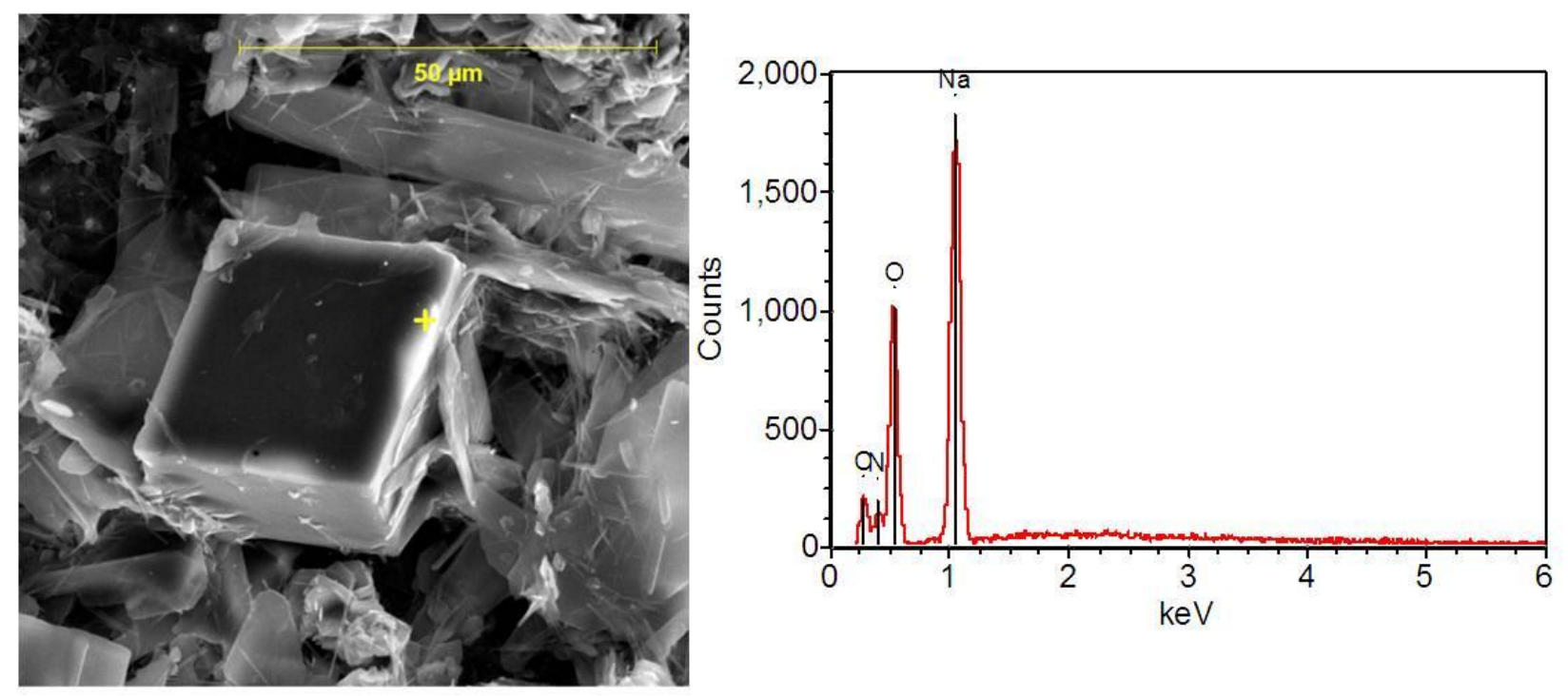


\section{LAB-RPT-13-00003 R0 \\ Attachment E}

\section{S13T001246}

Analysis by PLM showed few changes in appearance compared to Sample S13T001245; kogarkoite is reduced, carbonate is dominant, sodium oxalate needles are present, and natrophosphate is rare (Figure E-10). One sodium nitrate crystal was also observed, Figure E-11.

Figure E-10. Polarized Light Microscopy Analysis of Sample S13T001246.
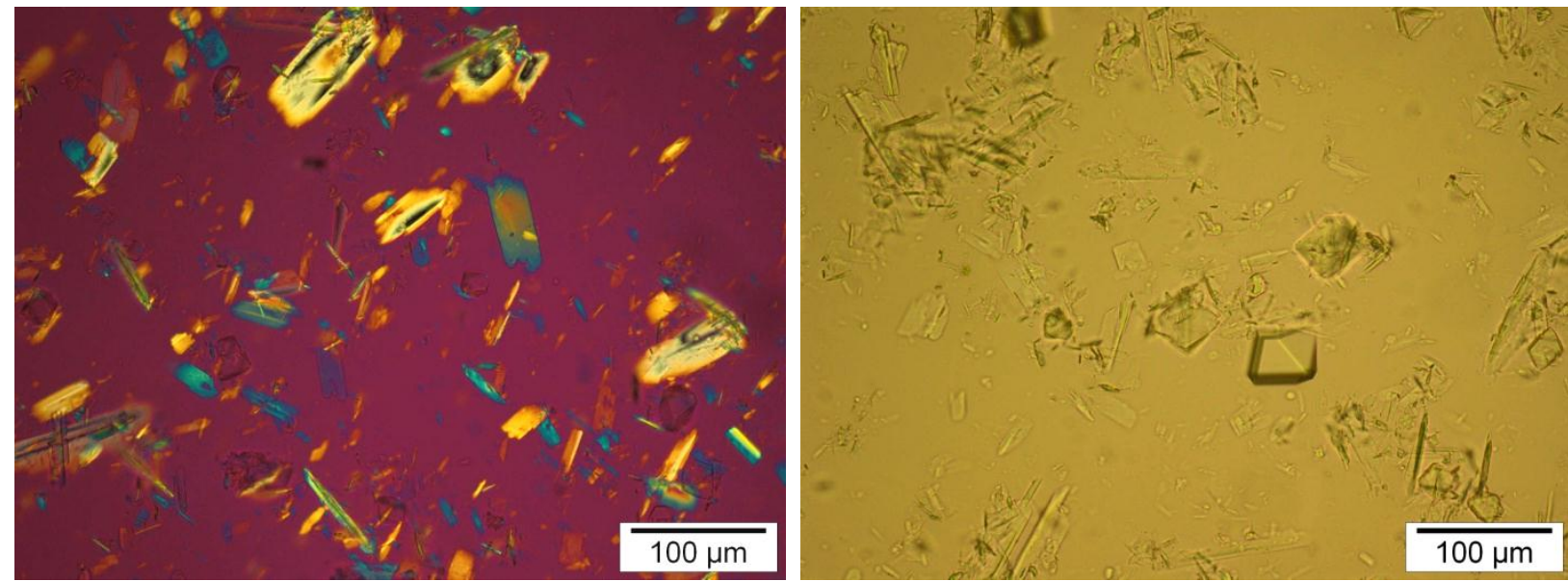

(S13T001246, 20x, crP+, Red I compensator)

(S13T001246, 20x, uncrP)

Figure E-11. Polarized Light Microscopy Analysis of Sample S13T001246 Showing a Sodium Nitrate Crystal.

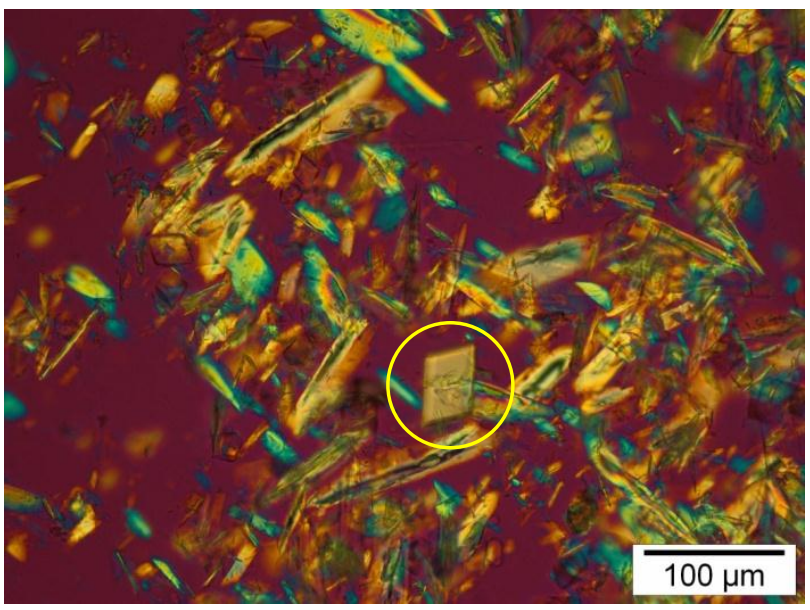

(S13T001246, 20x, crP+, Red I compensator) 


\section{LAB-RPT-13-00003 R0}

Attachment E

Analysis by XRD identified major phases as nitratine $\left[\mathrm{NaNO}_{3}\right]$ and thermonatrite $\left[\mathrm{Na}_{2} \mathrm{CO}_{3} \cdot \mathrm{H}_{2} \mathrm{O}\right]$. Kogarkoite $\left[\mathrm{Na}_{3} \mathrm{SO}_{4} \mathrm{~F}\right]$, natrophosphate $\left[\mathrm{Na}_{7} \mathrm{~F}\left(\mathrm{PO}_{4}\right)^{2} \cdot 19 \mathrm{H}_{2} \mathrm{O}\right]$, and sodium nitrite $\left[\mathrm{NaNO}_{2}\right]$ were identified as minor phases. The results are tabulated in Table E-3, and the XRD spectrum is shown in Figure E-12.

Table E-3. Phases and Relative Amounts Identified in Sample S13T001246.

\begin{tabular}{|l|l|l|l|}
\hline \multicolumn{1}{|c|}{ Chemical Name } & \multicolumn{1}{|c|}{ Mineral Name } & \multicolumn{1}{c|}{ Formula } & Rel. Amount \\
\hline Sodium Fluoride Sulfate & Kogarkoite & $\mathrm{Na}_{3} \mathrm{SO}_{4} \mathrm{~F}$ & Minor \\
\hline Sodium Fluoride Phosphate Hydrate & Natrophosphate & $\mathrm{Na}_{7} \mathrm{~F}\left(\mathrm{PO}_{4}\right)_{2} \bullet 19 \mathrm{H}_{2} \mathrm{O}$ & Minor \\
\hline Sodium Nitrate & Nitratine & $\mathrm{NaNO}_{3}$ & Major \\
\hline Sodium Nitrite & -- & $\mathrm{NaNO}_{2}$ & Minor \\
\hline Sodium Carbonate Monohydrate & Thermonatrite & $\mathrm{Na}_{2} \mathrm{CO}_{3} \cdot \mathrm{H}_{2} \mathrm{O}$ & Major \\
\hline
\end{tabular}


LAB-RPT-13-00003 R0

Attachment E

Figure E-12. X-Ray Diffraction Spectrum from Sample S13T001246.

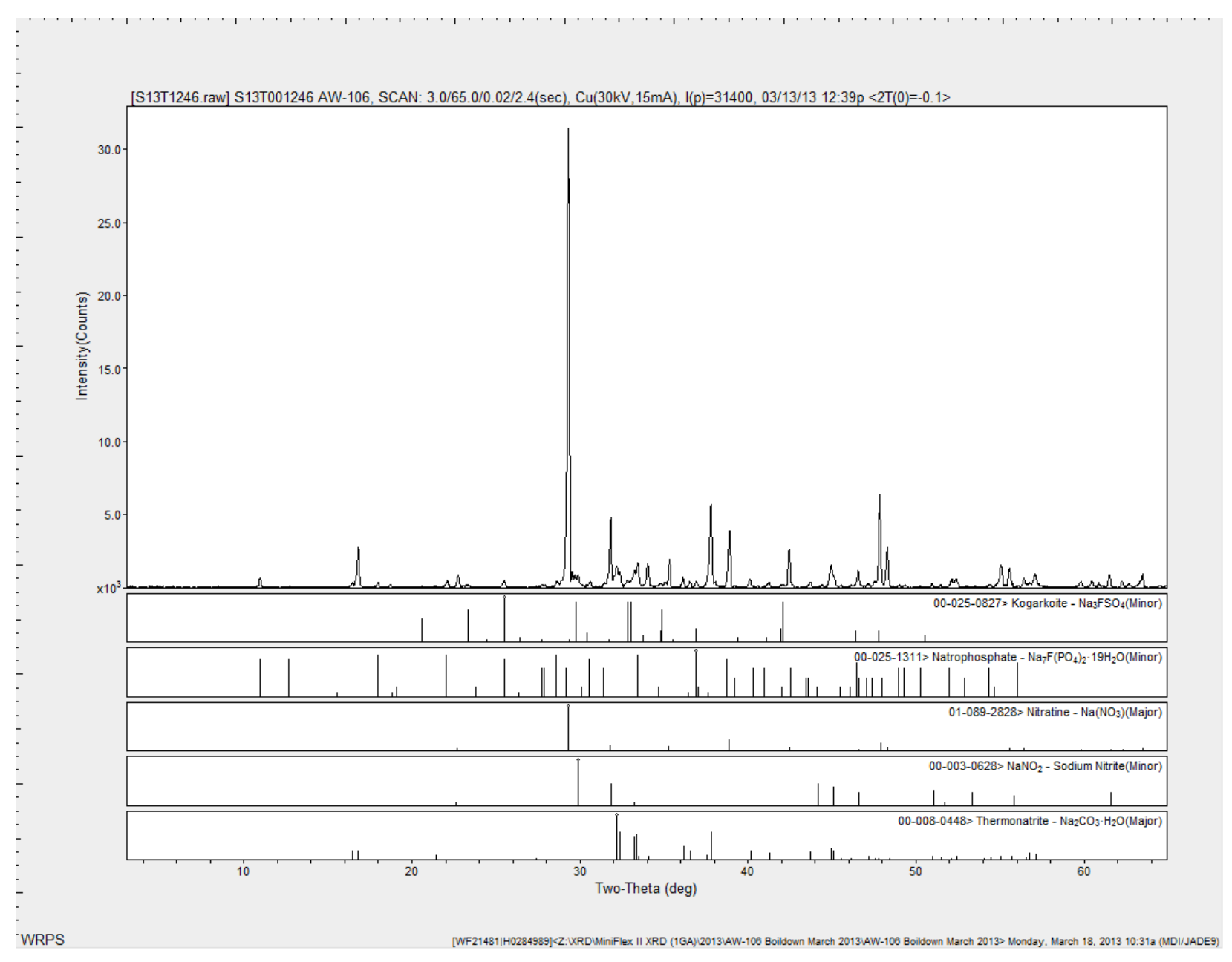

Analysis by SEM observed three major phases. The sample was dominated by larger, blade-like crystals which were chemically and morphologically consistent with sodium carbonate, Figure E-13. Sodium fluoride phosphate and sodium fluoride sulfate were also identified and were of similar morphology as the same phases seen in Samples S13T001244 and S13T001245, Figures E-14 and E-15. 


\section{LAB-RPT-13-00003 R0 \\ Attachment E}

Figure E-13. Scanning Electron Microscopy Image and Energy Dispersive Spectroscopy Spectrum of a Possible Sodium Carbonate Particle in Sample S13T001246.
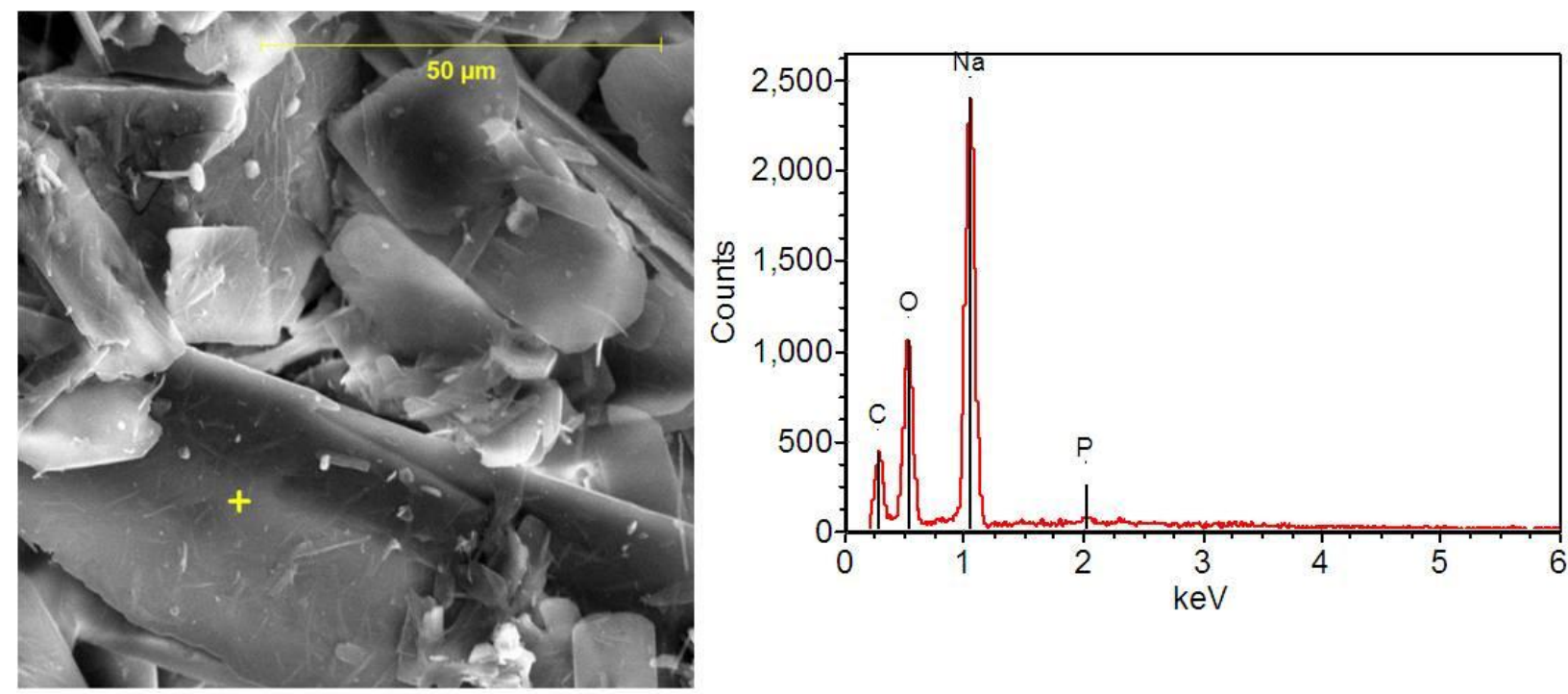

Figure E-14. Scanning Electron Microscopy Image and Energy Dispersive Spectroscopy Spectrum of Natrophosphate in Sample S13T001246.
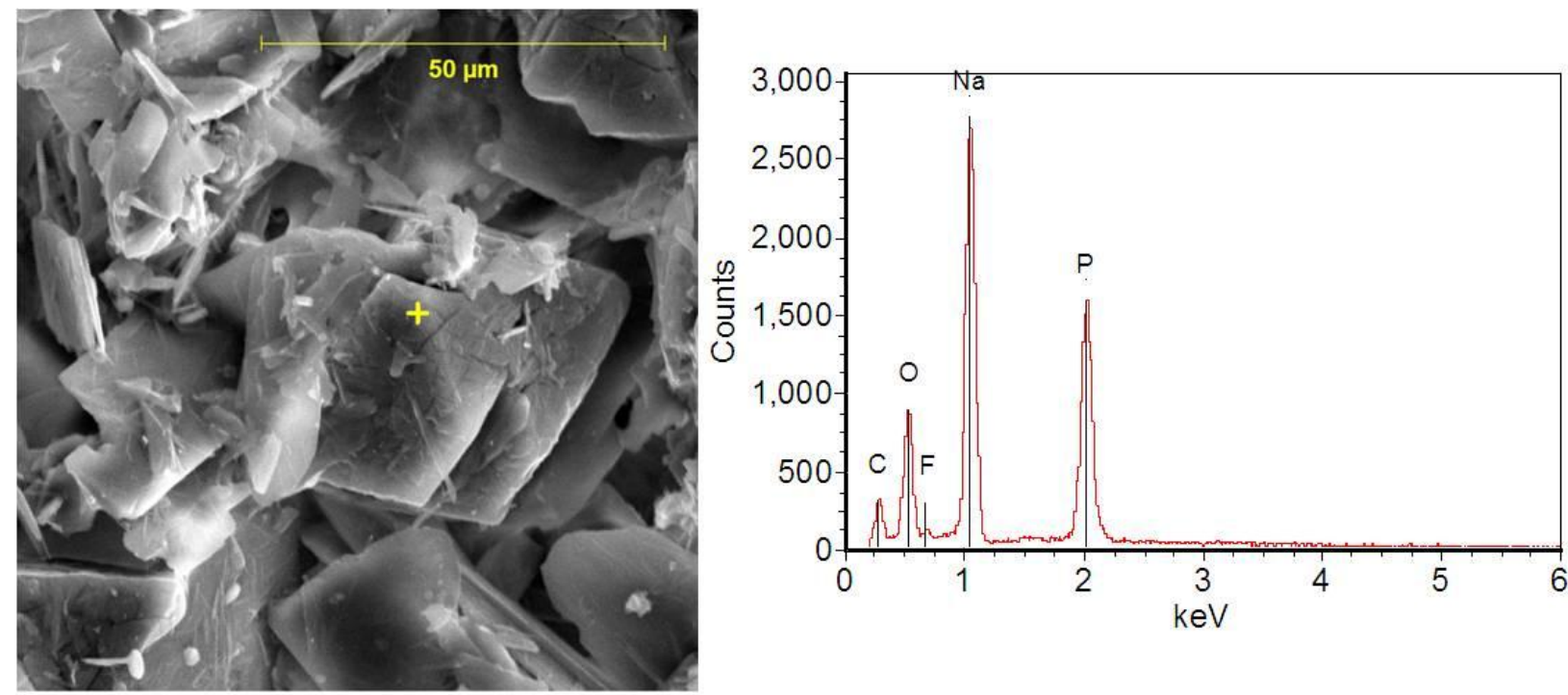


\section{LAB-RPT-13-00003 R0 \\ Attachment E}

Figure E-15. Scanning Electron Microscopy Image and Energy Dispersive Spectroscopy Spectrum of Sodium Fluoride Sulfate in Sample S13T001246.
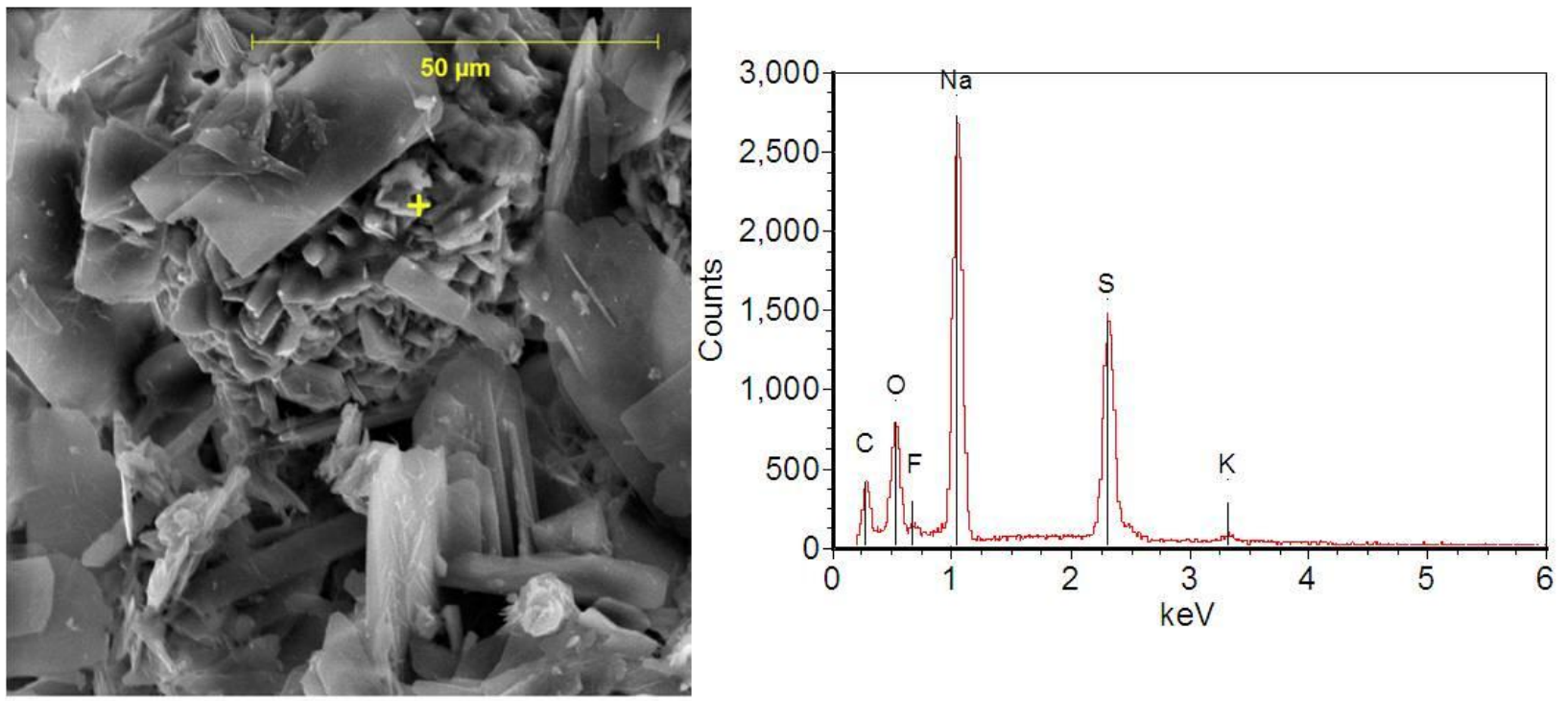


\section{LAB-RPT-13-00003 R0 \\ Attachment E}

\section{S13T001254}

Analysis by PLM showed three main phases; natrophosphate (isotropic), kogarkoite (irregular anisotropic), and oxalate needles, Figure E-16. Right image is a close-up on natrophosphate and oxalate needles. One crystal of carbonate was found in two preparation slides.

Figure E-16. Polarized Light Microscopy Analysis of Sample S13T001254.
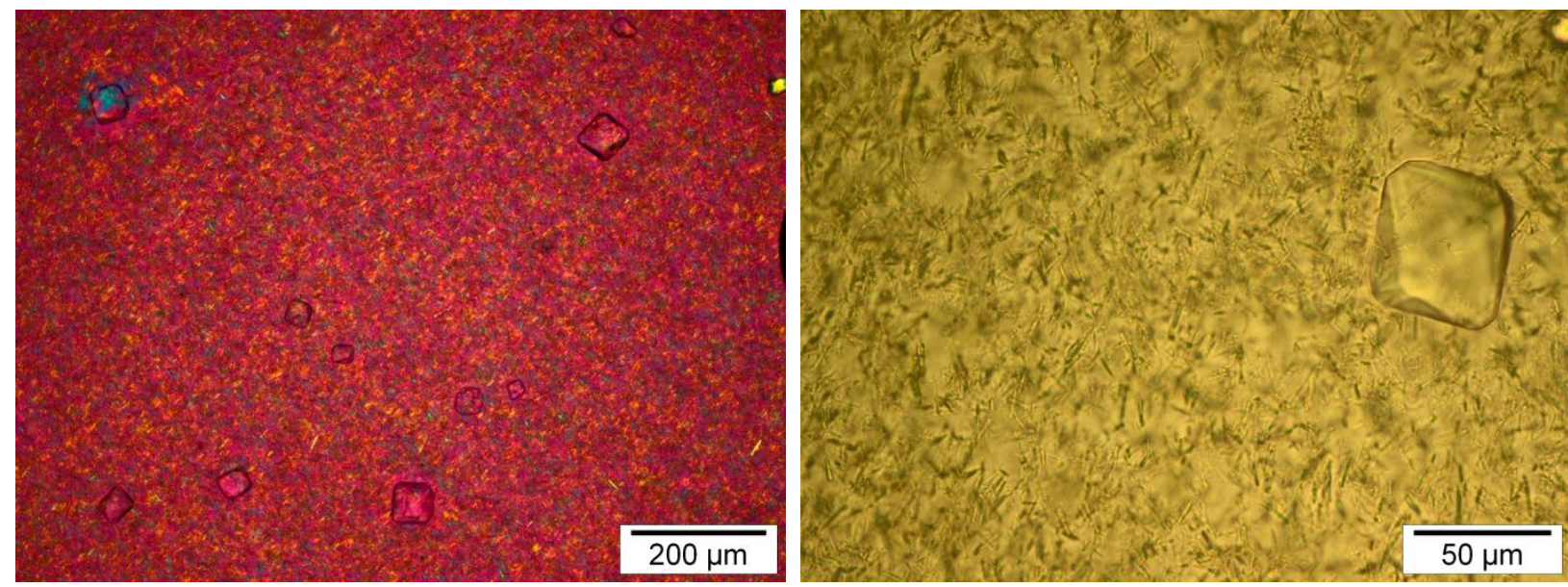

(S13T001254, 10x, crP+, Red I compensator)

(S13T001254, 40x, uncrP)

Analysis by XRD showed that the major phases of the sample were natroxalate $\left[\mathrm{Na}_{2} \mathrm{C}_{2} \mathrm{O}_{4}\right]$, nitratine $\left[\mathrm{NaNO}_{3}\right]$, and thermonatrite $\left[\mathrm{Na}_{2} \mathrm{CO}_{3} \cdot \mathrm{H}_{2} \mathrm{O}\right]$. Natrophosphate $\left[\mathrm{Na} 7 \mathrm{~F}\left(\mathrm{PO}_{4}\right)^{2} \cdot 19 \mathrm{H}_{2} \mathrm{O}\right]$ and sodium nitrite $\left[\mathrm{NaNO}_{2}\right]$ were identified as minor phases. The results are tabulated in Table E-4, and the XRD spectrum is shown in Figure E-17.

Table E-4. Phases and Relative Amounts Identified in Sample S13T001254.

\begin{tabular}{|l|l|l|l|}
\hline \multicolumn{1}{|c|}{ Chemical Name } & \multicolumn{1}{|c|}{ Mineral Name } & \multicolumn{1}{c|}{ Formula } & $\sim$ Rel. Amount \\
\hline Sodium Fluoride Phosphate Hydrate & Natrophosphate & $\mathrm{Na} 7\left(\mathrm{PO}_{4}\right)_{2} \cdot 19 \mathrm{H}_{2} \mathrm{O}$ & Minor \\
\hline Sodium Oxalate & Natroxalate & $\mathrm{Na}_{2} \mathrm{C}_{2} \mathrm{O}_{4}$ & Major \\
\hline Sodium Nitrate & Nitratine & $\mathrm{NaNO}_{3}$ & Major \\
\hline Sodium Nitrite & -- & $\mathrm{NaNO}_{2}$ & Minor \\
\hline Sodium Carbonate Monohydrate & Thermonatrite & $\mathrm{Na}_{2} \mathrm{CO}_{3} \cdot \mathrm{H}_{2} \mathrm{O}$ & Major \\
\hline
\end{tabular}


LAB-RPT-13-00003 R0

Attachment E

Figure E-17. X-Ray Diffraction Spectrum from Sample S13T001254.

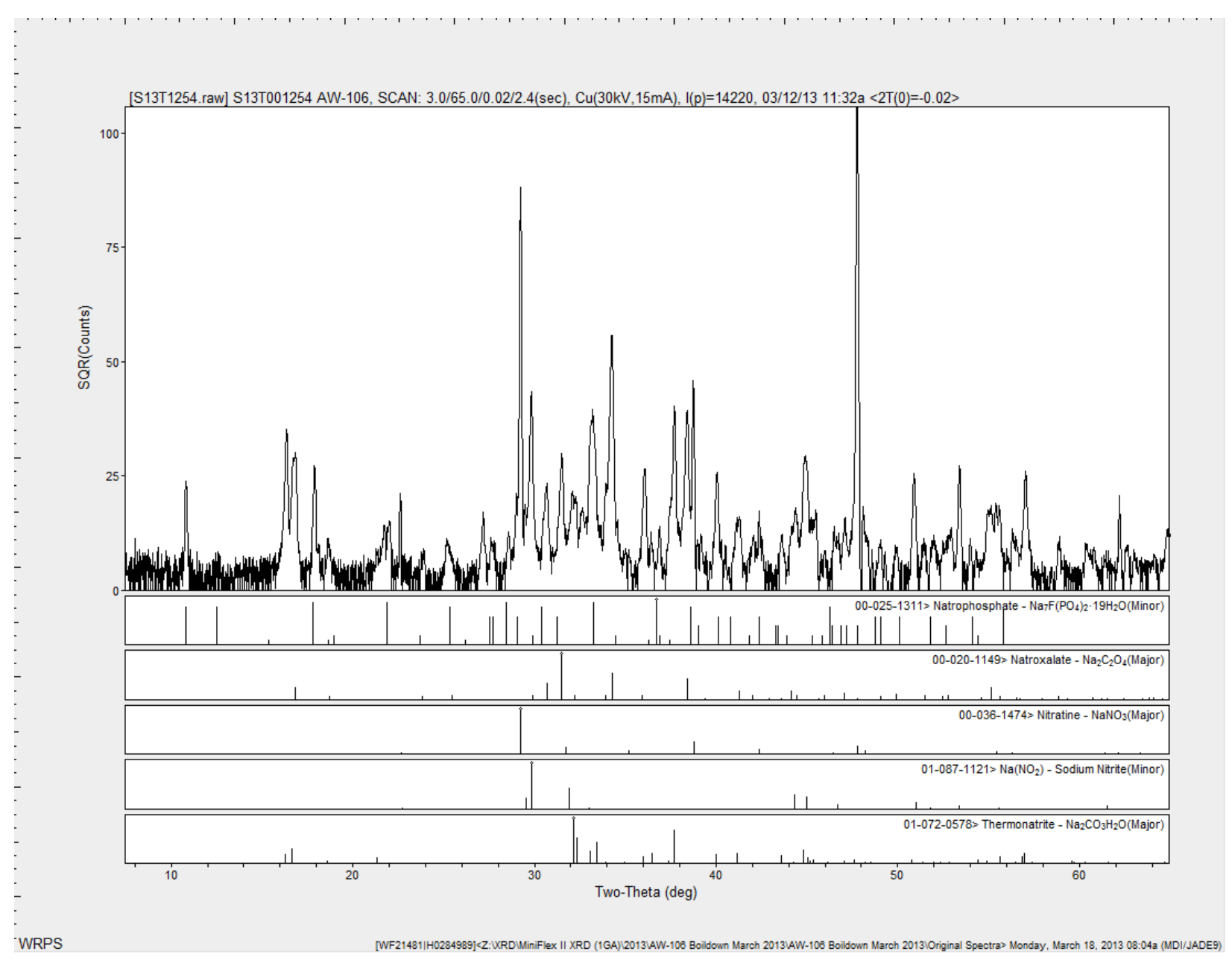

Analysis by SEM showed that the sample consisted mainly of small acicular particles rich in sodium, carbon, and oxygen, Figure E-18. Interspersed were larger crystals of natrophosphate, Figure E-19. A more magnified image of the acicular crystals showed the morphology of uniformly flat with rounded edges suggesting sodium oxalate, Figure E-20. 
LAB-RPT-13-00003 R0

Attachment E

Figure E-18. Scanning Electron Microscopy Images and Energy Dispersive Spectroscopy Spectrum of the Major Particulate in Sample S13T001254.
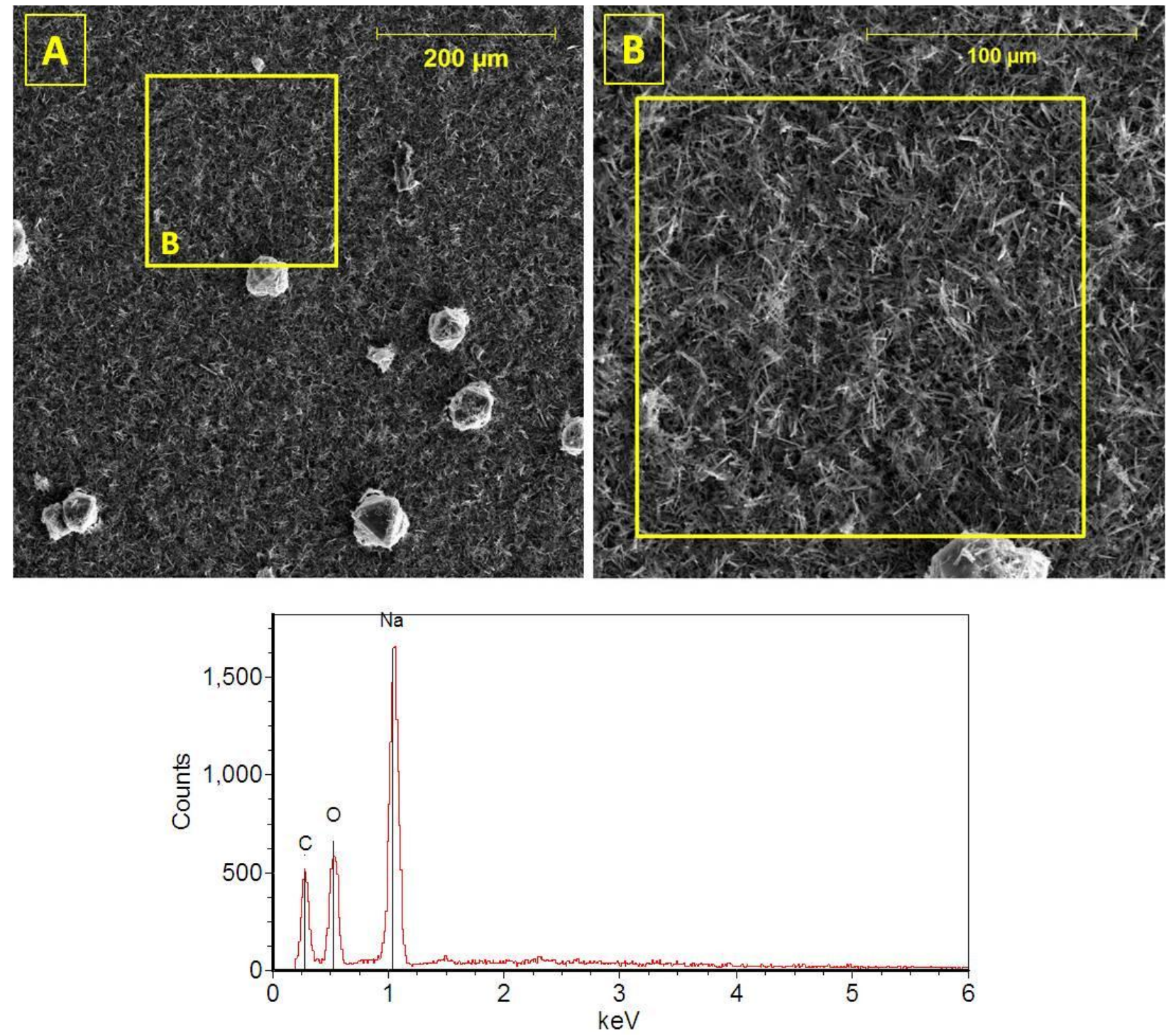


\section{LAB-RPT-13-00003 R0}

Attachment E

Figure E-19. Scanning Electron Microscopy Image and Energy Dispersive Spectroscopy Spectrum of Natrophosphate in Sample S13T001254.
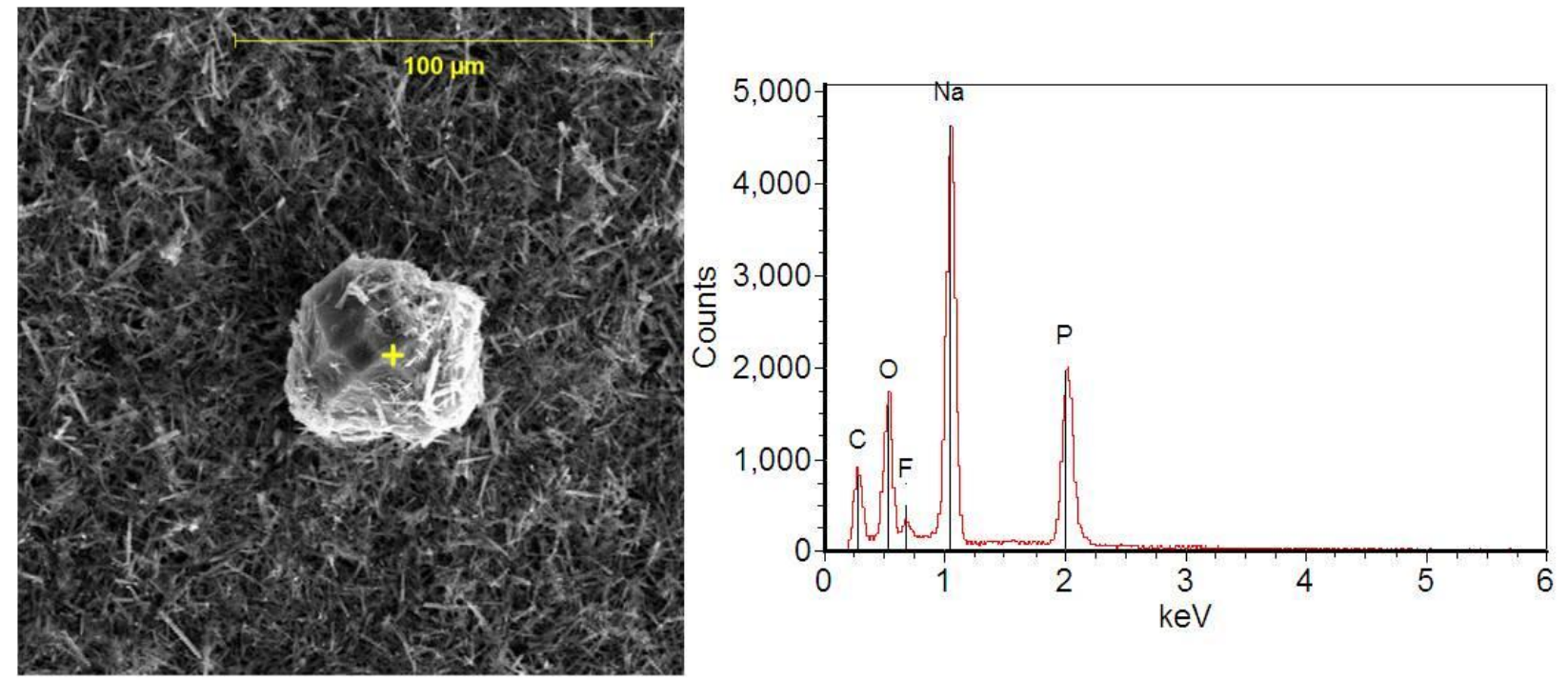

Figure E-20. Scanning Electron Microscopy Image and Energy Dispersive Spectroscopy Spectrum of Sodium Oxalate in Sample S13T001254.
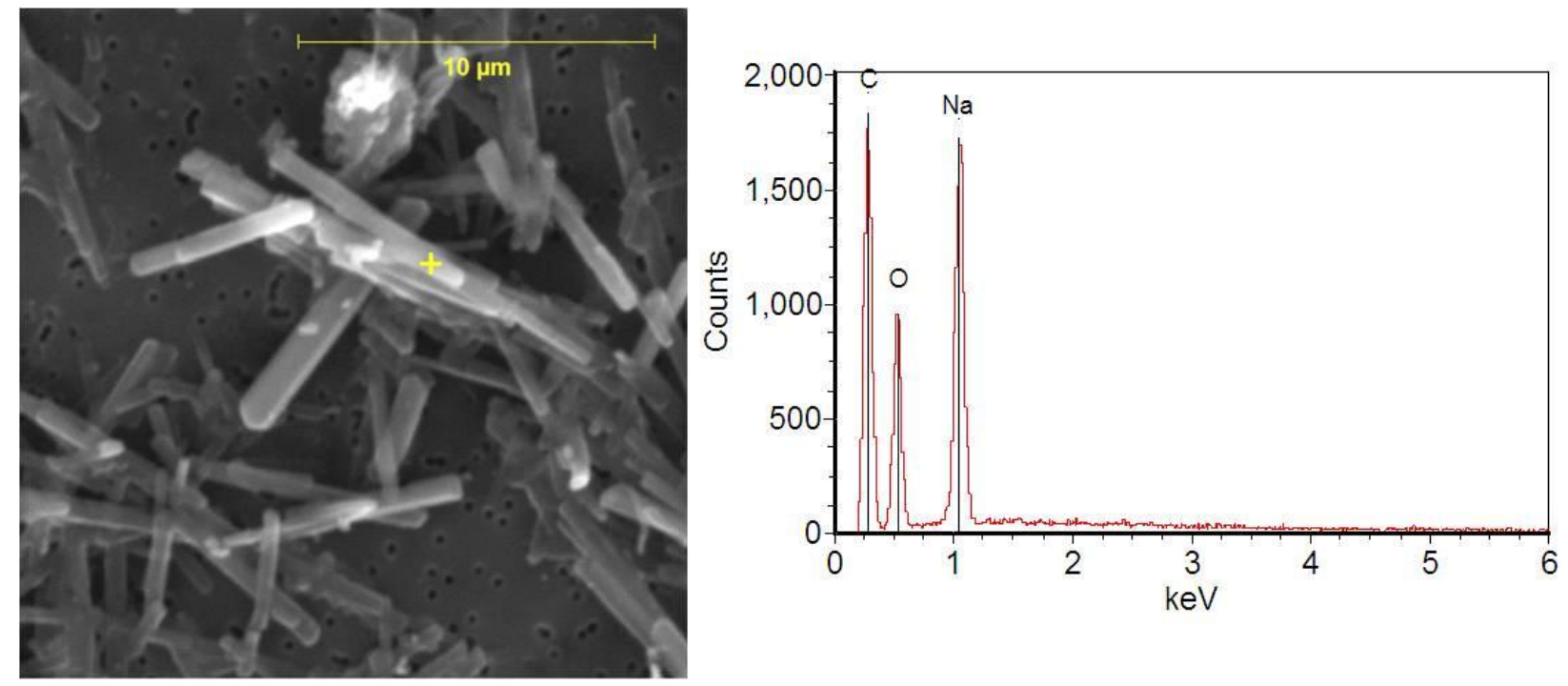
LAB-RPT-13-00003 R0

Attachment E

REFERENCES

ATS-LT-161-100, Rev. E-0, 222-S Laboratory Sample Preparation and Operating Procedure for Scanning Electron Microscopes, Washington River Protection Solutions LLC, Richland, Washington.

ATS-LT-507-103, Revision B-0, "222-S Laboratory X-Ray Diffractometry (XRD) Using the Rigaku MiniFlex II,” Washington River Protection Solutions LLC, Richland, Washington.

HNF-N-395-1, “Polarized Light Microscopy Sample Log,” pp. 116-117, 222-S Laboratory, Washington River Protection Solutions LLC, Richland, Washington.

HNF-N-710-1, “Rigaku MiniFlex II X-Ray Diffractometer (XRD) Maintenance and Operations,” p. 22, 222-S Laboratory, Washington River Protection Solutions LLC, Richland, Washington.

HNF-N-832-1, “PSEM Instrument Notebook,” p. 182, 222-S Laboratory, Washington River Protection Solutions LLC, Richland, Washington. 


\section{Electronically Approved by:}

UserName: Page, Jason (h2841343)

Title:

Date: Tuesday, 28 May 2013, 01:25 PM Pacific Time

Meaning: Approved by the author or delegate

UserName: Conner, John (h0028870)

Title: CHEMICAL ENGINEER

Date: Tuesday, 28 May 2013, 02:02 PM Pacific Time

Meaning: Approved by the customer or delegate

UserName: Howald, Carl (h2883252)

Title:

Date: Wednesday, 29 May 2013, 11:11 AM Pacific Time

Meaning: Approved by the Facility Manager or delegate

UserName: Seidel, Cary (h0009079)

Title: APD Manager

Date: Wednesday, 29 May 2013, 03:54 PM Pacific Time

Meaning: Approved by the Group Manager or delegate 
AW-106 Boildown Report Distribution List

\begin{tabular}{|l|l|c|c|}
\hline \multicolumn{1}{|c|}{ Organization } & \multicolumn{1}{|c|}{ Recipient } & $\begin{array}{c}\text { Test } \\
\text { Plan }\end{array}$ & $\begin{array}{c}\text { Final } \\
\text { Report }\end{array}$ \\
\hline WRPS & \multicolumn{1}{|c|}{-} & - & - \\
\hline Base Operations & \multicolumn{1}{|c|}{-} & - \\
\hline AW/242A/AP Facility Area & B. H. Von Bargen (Manager) & & $\checkmark$ \\
\hline & P. G. Haigh (Technical Specialist) & $\checkmark$ & $\checkmark$ \\
\hline Base Operations Process Engineering & N. W. Kirch (Manager) & & $\checkmark$ \\
\hline & J. M. Conner (Evaporator POC) & $\checkmark$ & $\checkmark$ \\
\hline Tank Farm Inventory & D. M. Nguyen (Tank Coordinator) & $\checkmark$ & $\checkmark$ \\
\hline \multirow{2}{*}{ 222-S Laboratory } & D. L. Renberger (Manager) & $\checkmark$ & $\checkmark$ \\
\hline Facility & K. J. Greenough (Manager) & $\checkmark$ & \\
\hline Integration and Control & J. R. Prilucik (Manager) & $\checkmark$ & $\checkmark$ \\
\hline Process Chemistry & C. M. Seidel (Manager) & $\checkmark$ & $\checkmark$ \\
\hline & J. S. Page (Boildown Testing POC) & $\checkmark$ & $\checkmark$ \\
\hline Analytical Project Management & J. M. Johnson (Manager) & $\checkmark$ & $\checkmark$ \\
\hline & R. W. Sosa (Project Coordinator) & $\checkmark$ & $\checkmark$ \\
\hline Advanced Technologies and Laboratories & C. S. Menjivar (Project Corrdinator) & & $\checkmark$ \\
\hline International, Inc. (ATL) & & & $\checkmark$ \\
\hline
\end{tabular}

